RENATA MAZZEI BATISTA

\title{
O "aikido" e a "capoeira" como fontes de inspiração para a dramaturgia do ator
}




\section{O "aikido" e a "capoeira" como fontes de inspiração para a dramaturgia do ator}

Tese de Doutorado apresentada à Escola de Comunicações e Artes da Universidade de São Paulo, para obtenção do Título de Doutor em Artes. Área de Concentração: Pedagogia do Teatro, Formação do Artista Teatral. Orientador: Prof. Dr. Armando Sérgio da Silva. 
BATISTA, R. M. O "aikido" e a "capoeira" como fontes de inspiração para a dramaturgia do ator.

Dissertação apresentada à Escola de Comunicações e Artes da Universidade de São Paulo para obtenção do Título de Doutor em Artes.

Aprovado em: 
Banca Examinadora

Prof. Dr.

Instituição:

Julgamento:

Assinatura:

Prof. Dr.

Instituição:

Julgamento:

Assinatura:

Prof. Dr.

Instituição:

Julgamento:

Assinatura:

Prof. Dr.

Instituição:

Julgamento:

Assinatura:

Prof. Dr.

Instituição:

Julgamento:

Assinatura: 


\section{AGRADECIMENTOS}

Muito, mas, muito obrigada!

À Deus, pela minha vida.

Aos meus pais, Ivani e José, que sempre estiveram ao meu lado me apoiando, sempre com muito amor e carinho. Sem a ajuda e o amparo de vocês com certeza essa trajetória teria sido muito mais difícil. Amo muito vocês!!!!

Aos meus professores, Ao Professor Armando pela orientação, sugestões, ideias e questionamentos que me fez ao longo do Doutorado tornando essa jornada possível. Sua sabedoria e paciência ao longo de todo esse processo foram fundamentais para que eu pudesse dar andamento ao meu trabalho.

Aos professores Eduardo Tessari Coutinho e Lenira Peral Rengel por terem aceitado participar do meu Exame de Qualificação e por seus comentários que me ajudaram a ter mais clareza para organizar as ideias, escrever a tese e aprofundar a pesquisa.

Ao prof. Gugu Quilombola e a todos os parceiros que tive no Quilombolas de Luz, com quem aprendi tudo o que sei sobre capoeira e sem os quais não teria tido condições de desenvolver esta pesquisa. A paciência, a atenção e o bom humor constante de vocês durante os treinos foi o que mais me estimulou a continuar aprendendo.

Ao Sensei Paulo Cremona e todos os parceiros do Cremona Dojo por terem me ensinado tanto sobre o aikido. Foi ali que começaram as primeiras ideias para uma pesquisa acadêmica e que culminaram neste trabalho. Sobre minha trajetória no aikido, não posso esquecer Sensei Nishida, diretor da FEPAI, com quem fui me aperfeiçoando dentro desta arte, e Sensei Roberto com quem iniciei os primeiros passos como aikidoista.

Aos parceiros desta pesquisa, os atores Carolina Loureiro, Gabriel de Almeida, Helena Semedo, Ignacio Muñoz, Isabella Leonel, Jefferson Mathias, Larissa Hupallo, Murilo Rocha, Nathalia Amadei e Wagner Cerqueira que compartilharam comigo esta jornada e que tornaram possível o desenvolvimento prático deste trabalho. Esta pesquisa não é só minha, mas de vocês também, pois muitas coisas só foram possíveis porque vocês estiveram presentes.

À Thaís Dias e Elza Dias que desenharam e confeccionaram os figurinos de Hamlet com tanta atenção e carinho. Thaís, os diálogos com você sempre foram 
tranquilos e produtivos. Você entendeu como ninguém a pesquisa e enriqueceu o trabalho com as suas propostas.

Ao Roberto Monteiro, meu grande amigo e parceiro de tantos momentos do teatro, por ter me ajudado a editar os vídeos que fazem parte do DVD anexado a esta tese.

À Daniela Jorge e Leandro Souza que me ajudaram filmando e fotografando as cenas em um dos ensaios e agilizando o processo.

Ao Francisco Madureira, um grande fisioterapeuta e amigo, que me "arrumou" em alguns momentos de maior stress e dores de tanto tempo no computador, permitindo que eu seguisse em frente.

Ao Fernandes, Gustavo, Denilson, Zito e Newton e a todos meus amigos que trabalham na USP que sempre me acolheram com tanto carinho e atenção ao longo da minha trajetória na Pós.

A Nani Barbosa, uma cantora incrível, com quem compartilhei muitos aspectos desta pesquisa me ajudando a encontrar uma voz para o que eu estava fazendo.

Ao Rogério de Moura, grande amigo do Cepeca, que revisou com tanto cuidado minha tese.

Ao Anderson Borges Costa, meu amigo e parceiro das artes, que tão atenciosamente revisou o Abstract dessa tese.

Ao Cepeca, os Cepecanos que com seus olhares atentos, ao longo de 10 anos, contribuíram muito com as minhas pesquisas. Foi com sua participação generosa que fui descobrindo o que era ser pesquisadora. Em todos os momentos em que me senti solitária, foi com vocês que encontrei amparo e estímulo para continuar.

À minha família, sou extremamente feliz por ter uma família grande e unida que sempre me apoiou, me incentivou, me assistiu em meus trabalhos, marcando presença em cada etapa da minha caminhada permeada por muitas alegrias, mas também por muitas dificuldades. Fui abençoada com irmãos de sangue e de coração, mães e pais de sangue e de coração, que sempre estiveram ao me lado me incentivando. Sem o amor e carinho de vocês não teria chegado aonde cheguei. Amo vocês!!!

À tia Angelina, professora doutora, que me ajudou lendo este trabalho e me dando preciosas devolutivas para que eu pudesse seguir com a escrita da tese de forma mais tranquila e segura.

Aos meus amigos de trabalho, de balada, de treino, de estudos, todos meus amigos que direta ou indiretamente me deram alento e descanso das atribulações do dia 
a dia. Com vocês aprendi, me diverti, conversei, desabafei, chorei e ri. Cada um de vocês está em meu coração como as grandes preciosidades que tenho na vida. Parafraseando Augusto Cury, a felicidade está em conquistar aquilo que o dinheiro não pode comprar. Sou, portanto, extremamente feliz por estar rodeada de tantas pessoas que me ajudam a crescer.

Teatro Escola Macunaíma, Débora Hummel (coordenadora pedagógica) e ao Luciano Castiel (diretor) que me permitiram ensaiar nas dependências da escola, possibilitando o avanço da prática com os atores.

Por fim, obrigada a todas as pessoas que, direta ou indiretamente me ajudaram a dar andamento a esta pesquisa. 


\section{RESUMO}

BATISTA, R. M. O “aikido" e a "capoeira" como fontes de inspiração para a dramaturgia do ator. 2017. 215 f. Tese (doutorado) - Escola de Comunicações e Artes, Universidade de São Paulo, São Paulo, 2017.

O que será apresentado nesta tese diz respeito a uma parte da minha trajetória como atriz e professora de teatro, e é permeada pelas contribuições do "aikido" e da "capoeira". Essas duas artes marciais de origens culturais distintas, uma japonesa e outra afro-brasileira, que têm em sua essência elementos técnicos e artísticos bastante ricos, forneceram-me material para responder a alguns questionamentos sobre a formação do ator desde a preparação para a cena à criação de uma dramaturgia construída a partir da prática.

A tese, portanto, trata da investigação iniciada a partir da minha prática nessas artes marciais e, que teve continuidade com um grupo de atores voluntários que se propuseram a experimentar os procedimentos elaborados ao longo do processo deste doutoramento. Todo o caminho trilhado foi construído tendo como base o treinamento que visou o aprimoramento individual e relacional na busca pelo autoconhecimento, a ampliação de repertório, a potencialização do estado de prontidão e de presença, a estimulação da criatividade e a disponibilidade corporal para a improvisação e o jogo.

Neste trabalho, quando tratamos do corpo, referimo-nos a todo o conjunto psicofísico desde o aparato sensório motor até as emoções, ideias e memórias, de modo que todas essas informações fizessem parte desta investigação cênica. Tendo como base esse conjunto corporal complexo, concebemos ao longo do treinamento um resultado cênico que procurou apresentar o que foi desenvolvido por mim e pelos atores durante a prática. A fim de auxiliar a criação da dramaturgia, recorremos ao texto Hamlet de William Shakespeare, cujas circunstâncias e personagens funcionaram como estímulos para as criações dos atores. Assim, o trabalho cênico construído por nós foi resultado de um diálogo entre os elementos extraídos do "aikido" e da "capoeira" e algumas cenas de Hamlet.

Por fim, pretendemos nesta tese apresentar a forma em que utilizamos o "aikido" e a "capoeira" como recursos para transformar o corpo cotidiano do ator em um corpo cênico, de modo que suas qualidades fossem potencializadas e alguns limites superados, respeitando-se as características de cada um.

\section{PALAVRAS CHAVE}

Aikido, capoeira, treinamento, corpo, criação. 


\begin{abstract}
BATISTA, R. M. Aikido and capoeira as sources of inspiration for the dramaturgy of the actor. 2017. 215 f. Tese (doutorado) - Escola de Comunicações e Artes, Universidade de São Paulo, São Paulo, 2017.

What is presented in this thesis concerns a part of my career as an actress and drama teacher, which was permeated by contributions of aikido and capoeira. These two martial arts from different cultural backgrounds, Japanese and African-Brazilian, which have at their core very rich technical and artistic elements, provided me with sufficient material to answer some questions about the training of the actor, from the preparation for the scene to the creation of a dramaturgy constructed in practice. This thesis therefore deals with this investigation that began with my practice in these martial arts and continued with a group of actors who voluntarily proposed to try the procedures developed during the doctoral process. The entire path taken by us in this research was built based upon the training aimed at the individual and relational improvement with the search for self-knowledge, broadening repertoire, enhancement of the state of readiness and presence, stimulation of creativity and availability body for improvisation and for game. In this work, when we treat the body, we refer to the whole psychophysical set from the sensory motor apparatus to the emotions, ideas and memories, so that all this information became part of this scenic research. Having as reference this complex body conjunct, we conceived during the training a scenic result that aimed at presenting what was developed by me and by the actors during our practice. In order to help the creation of the dramaturgy, we used as a basis the play "Hamlet", by William Shakespeare, whose circumstances and characters acted as stimuli to the creation of the actors. Thus, the scenic work built by us was the result of a dialogue between the extracted elements of aikido and capoeira and some Hamlet scenes. Finally, we intend in this thesis to show how we used aikido and capoeira as resources to transform the actor's everyday body into a scenic body, so that their qualities were enhanced and some limits overcome, respecting the characteristics of each one.
\end{abstract}

\title{
KEY WORDS
}

Aikido, capoeira, training, body, creation. 


\section{SUMÁRIO}

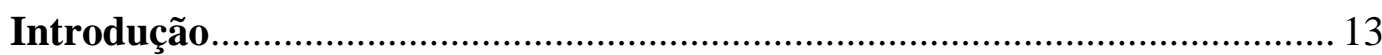

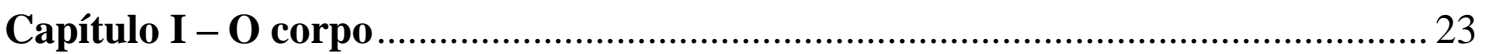

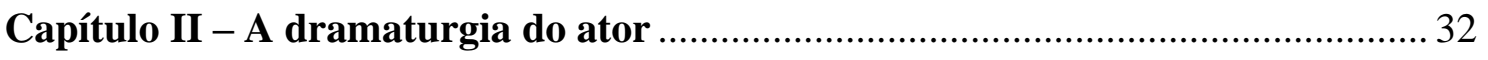

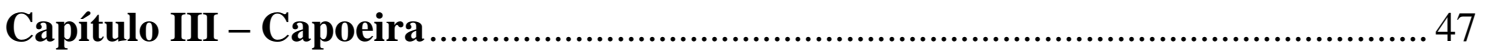

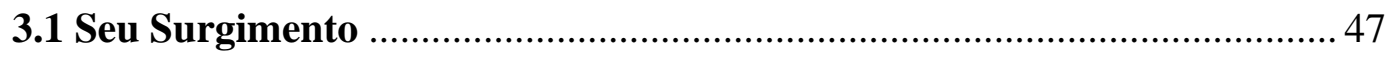

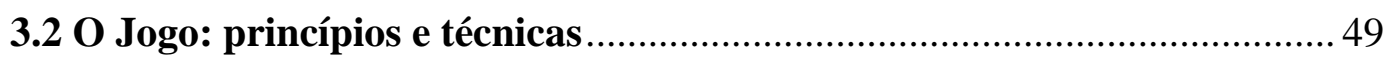

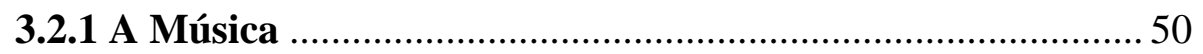

3.2.2 Andamento da Roda e as técnicas....................................... 59

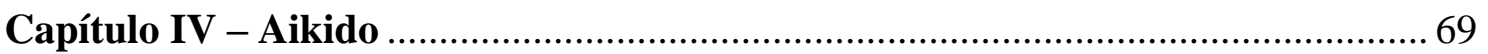

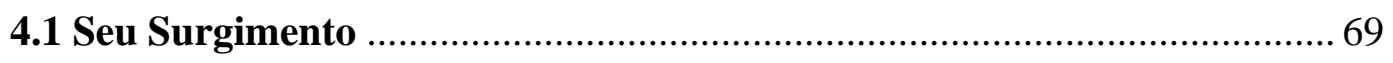

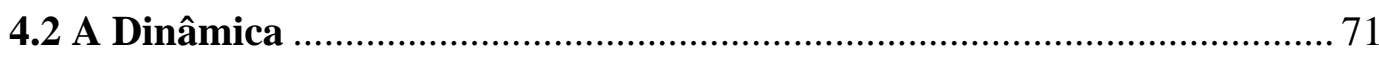

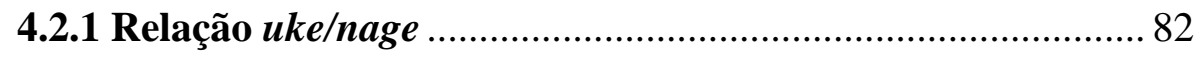

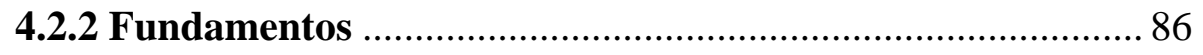

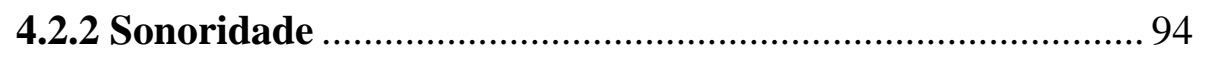

Capítulo V - O treinamento como caminho para preparação do ator e criação

tendo como base elementos do "aikido" e da "capoeira" ..................... 96

5.1 Repetição como caminho para novas descobertas ................................ 107

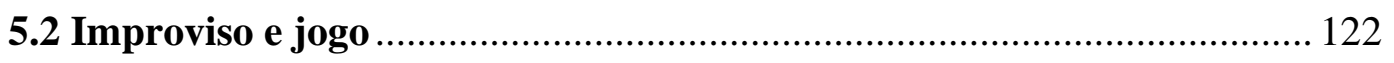

5.2.1 Improviso individual ................................................. 133

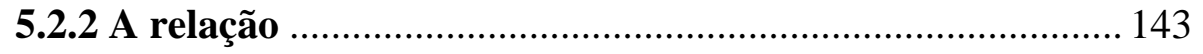

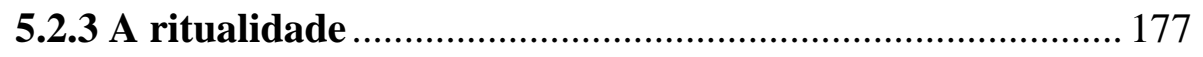

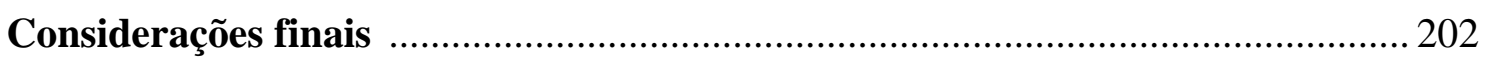

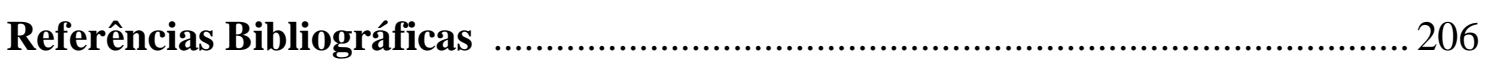

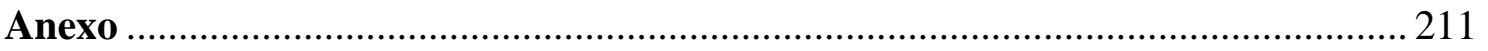




\section{Índice de imagens:}

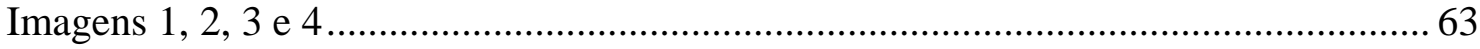

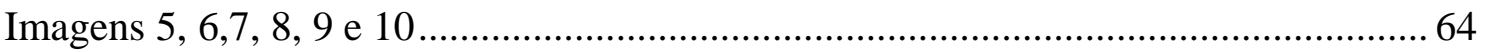

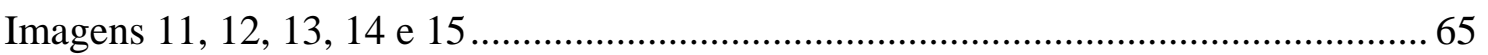

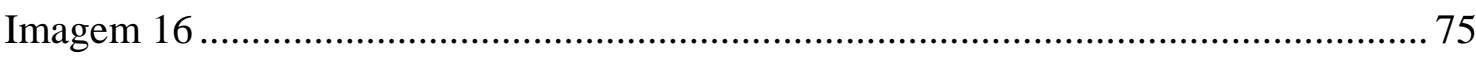

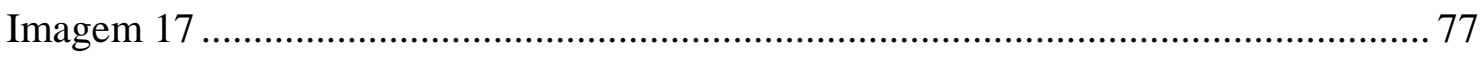

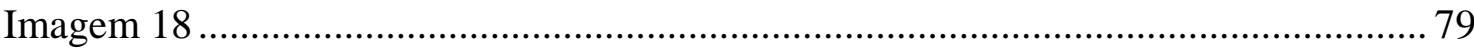

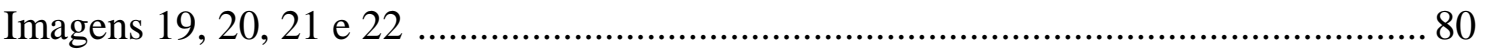

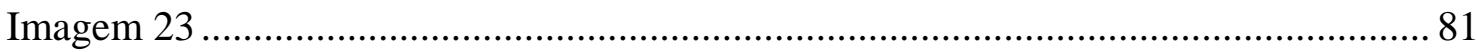

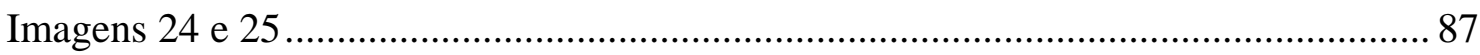

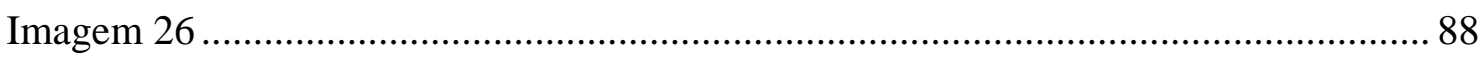

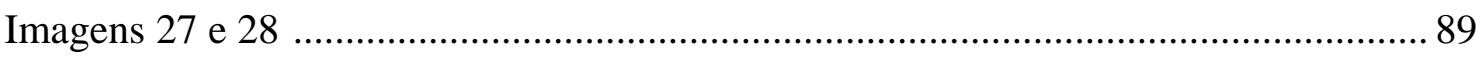

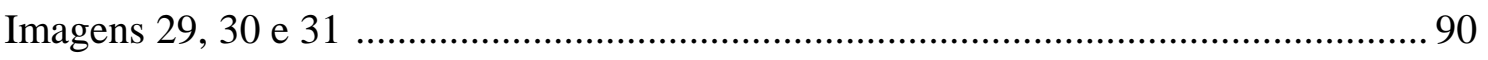

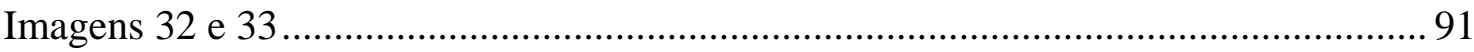

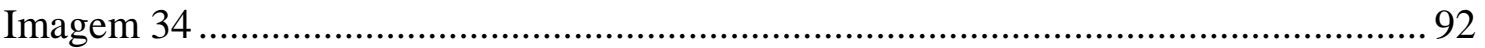

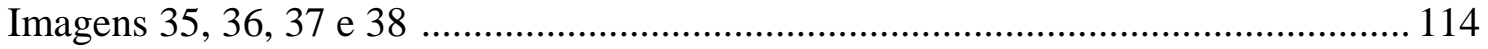

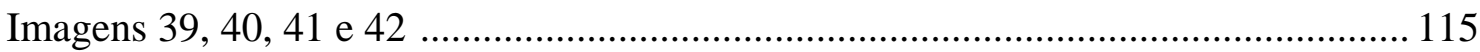

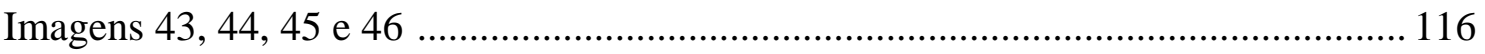

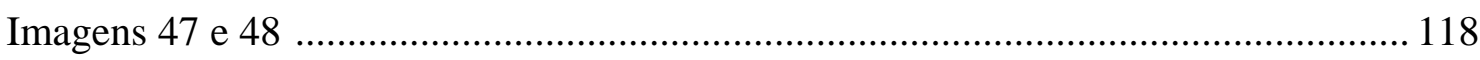

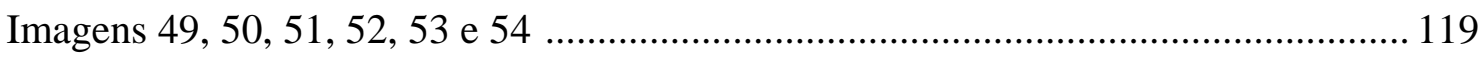

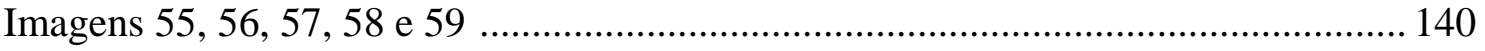

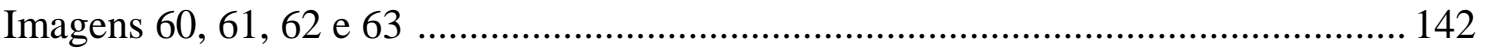

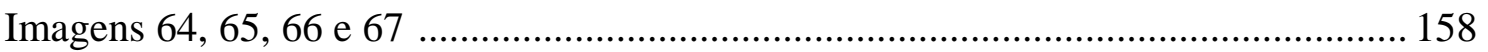

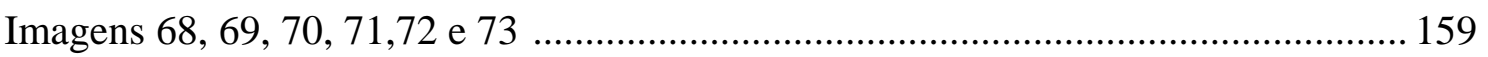

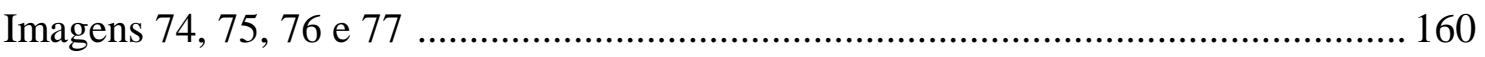

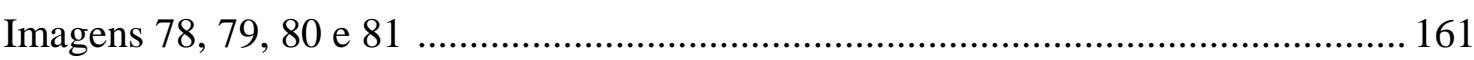

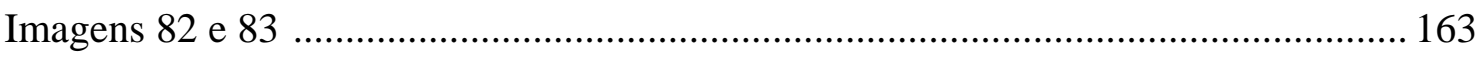

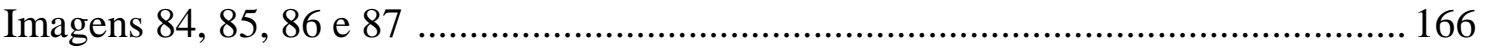

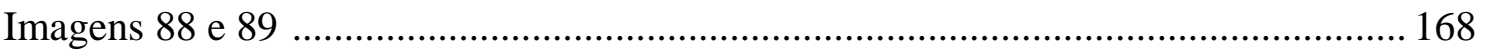

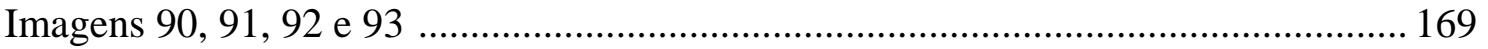

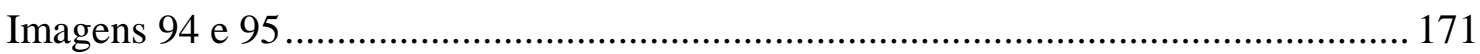

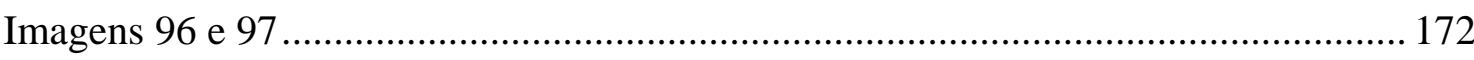

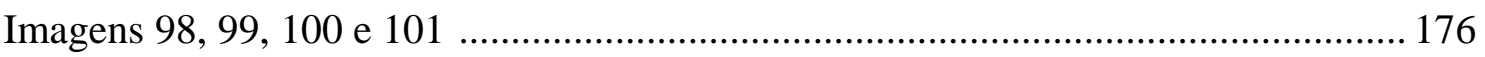




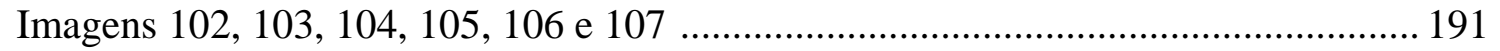

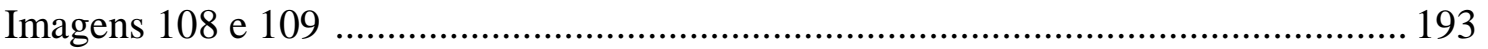

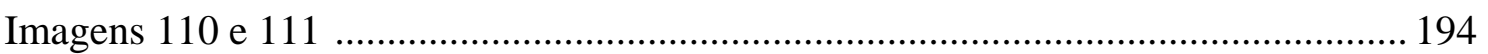

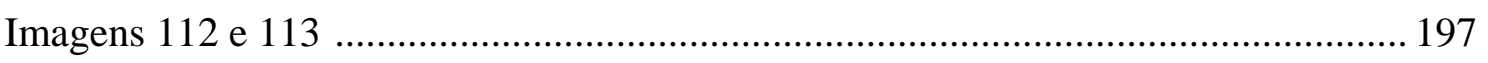

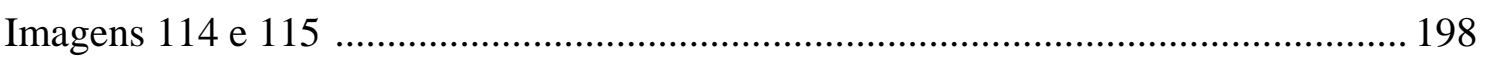

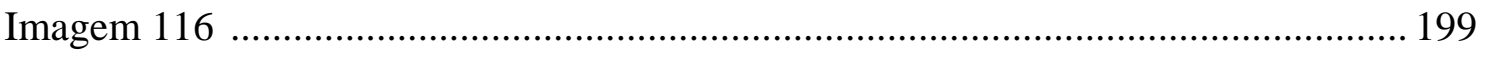

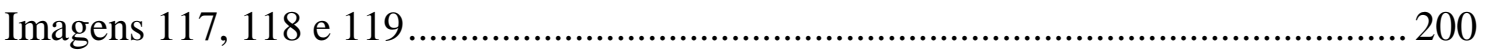

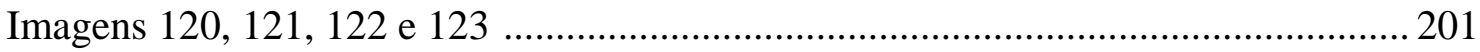




\section{Introdução}

As primeiras sementes desta pesquisa foram cultivadas em meu mestrado na Escola de Comunicação e Artes da Universidade de São Paulo, ECA-USP, sob orientação do prof. dr. Armando Sérgio da Silva, concluída em 2009, em que teve o "aikido" como recurso técnico e artístico para auxiliar o ator na criação de ações físicas.

Comecei o "aikido" em 2003, primeiramente na Associação Lenwakan e depois no Cremona Dojo, ambos ligados à Federação Paulista de Aikido, FEPAI. Nesse período, aprofundei os meus conhecimentos sobre esta arte marcial, chegando ao $2 .^{\circ}$ DAN $^{1}$ em novembro de 2010. Toda a pesquisa realizada no mestrado teve como referência técnica o que foi aprendido nesses dois dojos ${ }^{2}$. Além desses dois lugares, visitei outros dojos, realizei alguns workshops e participei de seminários com convidados internacionais, com o propósito de aprofundar-me nas habilidades dessa arte marcial e ampliar as relações sociais dentro do "aikido". Nestas visitas estabeleci contato direto com Sensei Joca Pena, da FEPAI, Sensei Palma, de Buenos Aires e Sensei Wagner Bull, do Instituto Takemussu. Todas as experiências foram importantes para que pudesse ampliar a forma de ver e praticar o "aikido". Além disso, durante todo esse período, no sentido de aprofundar minha pesquisa, procurei estudar sobre grupos e profissionais do teatro que recorriam ao aikido para o trabalho do ator como o grupo Nova Dança, com quem realizei alguns workshops de contato-improvisação e outros que focavam a respiração e a espiralidade do aikido para a preparação corporal como a oficina realizada em 2006 com Letícia Sekito e Ivan Okuyama com o nome "Princípios do Aiki e Dança Contemporânea". Fui, então, aos poucos descobrindo outras técnicas criadas a partir do "aikido" como o Kinomichi criado na França pelo Mestre Masamichi Noro em 1979, atualmente muito difundido pela Cia. de Teatro Balagan, o Shinshin Toitsu Aikido fundado em 1974 por Sensei Koichi Tohei e o Tenchi Tessen criado por George Stobbaerts.

No período em que treinei "aikido", percebi que as técnicas selecionadas como suporte para a criação das cenas, ativavam meu corpo como um todo, despertando

1. DAN se refere a graduação do aikido assim que o aikidoista conquista a faixa preta. O praticante recebe dessa forma a primeira graduação que é o 1 DAN. Após 2 anos de treino, via de regra, sendo aprovado no exame, pode ser promovido ao 2 DAN. E assim por diante.

2. Termo japonês para designar o lugar em que se pratica arte marcial. 
sensações, imagens e me deixando em um estado de maior prontidão e criatividade. Aproveitei então essas impressões para investigar no mestrado realizado entre 2006 e 2009 de que forma essas descobertas poderiam ajudar a transformar o movimento em ação, e a ação em dramaturgia corporal. A princípio realizei uma pesquisa solitária, em que a investigação desenvolvida voltava-se para a criação de partituras físicas e a relação com objetos de cena. Como resultado prático, elaborei o monólogo Separação de corpos que teve como inspiração dramatúrgica minha experiência de divórcio, que vivia na época, e as técnicas do "aikido". A relação que poderia se desenvolver com outros parceiros não havia sido experimentada, assim, o foco da investigação criativa foi individualizada. $\mathrm{O}$ principal fator para que a pesquisa não tivesse caminhado no sentido de explorar os aspectos relacionais do "aikido" foi o de eu não ter conseguido um grupo estável para trabalho durante o período de mestrado. Entretanto, na época, eu já ministrava aulas no Teatro Escola Macunaíma, em que aproveitei minha condição de professora de Expressão Corporal para aprimorar e aprofundar o que estava pesquisando, ao mesmo tempo em que contribuía para a formação dos jovens atores. Foi um período de muitas experimentações e descobertas que refletiam positivamente no trabalho solo, pois, tanto me colocava como coordenadora e provocadora, com um olhar de fora da cena, como atriz vivenciando com meu próprio corpo as experimentações que estava elaborando na época. Essas experiências me ajudaram a organizar melhor as ideias, e a para dar seguimento às minhas investigações cênicas a partir do "aikido".

Mesmo depois de terminado o meu vínculo com a universidade devido à conclusão do Mestrado, em 2009, segui nessa linha de pesquisa e comecei a ministrar oficinas com o título "O aikido e o Trabalho do Ator" para atores experimentados, iniciantes e pessoas sem nenhuma experiência e/ou vivência em teatro. Essas oficinas aconteceram em diversos lugares, tais como: Oficinas Culturais do Estado Oswald Andrade (de agosto a dezembro de 2009), nos campi da USP como parte do Circuito do TUSP (de março a junho de 2010) e na Universidade Federal de Ouro Preto (UFOP) como uma das atividades da VI Semana de Artes (maio de 2010). Tanto no Circuito do TUSP como na Semana de Artes da UFOP tive oportunidade de apresentar o monólogo Separação de corpos e discutir sobre o processo prático com o grupo presente. Tudo o que experienciei nesse intervalo, que se deu entre o fim do mestrado e o começo do doutorado foi importante, haja vista, que ajudou a amadurecer minhas investigações, ampliando as possibilidades investigativas sobre o "aikido", e trouxe subsídios para elaborar o projeto de doutorado. 
Um dos pontos que me chamou a atenção durante o mestrado e que foi reforçado, sobretudo, no período em que ministrei as oficinas, foi o fato de não haver outros atores na prática para que eu pudesse focar na relação entre agentes, uma vez que o "aikido" é uma arte marcial que tem como foco a conexão entre os parceiros. Consequentemente, durante as oficinas ministradas, pude pensar este aspecto, experimentando com os participantes uma continuidade da pesquisa, nesse sentido.

Seguindo com as pesquisas pelas artes marciais, aventurei-me na "capoeira" em 2012 com o grupo Quilombolas de Luz-Bela Vista enquanto seguia paralelamente o “aikido". Juntamente com essa prática, foi iniciada uma pesquisa teórica em bibliografia especializada com o intuito de que o conhecimento não ficasse apenas nos treinos, mas que o contexto que cerca essa arte marcial fosse compreendido. Da mesma forma como com o aikido, comecei a realizar uma pesquisa sobre o uso da capoeira para o trabalho do ator e entrei em contato com inúmeros trabalhos acadêmicos e não acadêmicos que partem dos princípios dessa arte marcial para aprofundar o trabalho cênico como o de Evani Tavares Lima que desenvolveu na UFBA (Universidade Federal da Bahia) uma investigação visando o treinamento do ator por meio da capoeira angola e o de Adriana de Carvalho Barão que realizou a pesquisa "A Performance Ritual da Roda de Capoeira" em seu mestrado na UNICAMP (Universidade de Campinas).

Pesquisando as origens da "capoeira", vendo praticantes jogando e praticando, pude perceber que apesar de ser uma arte marcial, assim como o "aikido", possui uma dinâmica diferente por ter culturalmente pontos de partida diversos (uma japonesa e outra afro-brasileira). Percebi, portanto, que os movimentos da "capoeira" traziam elementos estéticos e psicofísicos diferentes da arte marcial japonesa, não só pela presença de ritmos musicalmente demarcados, mas também pela forma com que o corpo se mobiliza. Dessa forma, comecei a estudar ambas as artes e a investigar a maneira como elas, conjuntamente, poderiam contribuir no trabalho do ator. Compreendi que ambas, além de proporcionarem uma excelente preparação corporal, têm em comum a importância da relação entre os parceiros, um aspecto que há muito desejava experimentar no teatro. Percebi então que esse poderia ser um novo estímulo para meu trabalho como pesquisadora das artes cênicas. Concluí, portanto, que uma pesquisa que unisse a ambas poderia ser de grande enriquecimento para o trabalho do ator.

A partir dessas experiências descritas, elaborei o projeto e com ele me matriculei no doutorado em 2013. Logo no início da pesquisa me juntei a alguns atores, em sua maioria, recém-formados e sem experiência no "aikido" e na "capoeira", mas que 
tinham muito interesse em participar do processo. E assim iniciei as primeiras experimentações com dois núcleos distintos: um composto por Nathalia Amadei, Larissa Hupallo e Carolina Loureiro de Brito e o outro por Wagner Cerqueira que além de ator era capoeirista. Em ambos os processos comecei a desenvolver experimentações a partir das técnicas do "aikido" e da "capoeira". Em um determinado ponto do processo começamos a recorrer a estímulos dramatúrgicos como mais um elemento para auxiliar a criatividade, sendo no caso das atrizes o texto Inferno, de Dante Alighieri, que foi substituído posteriormente por Negrinha, de Monteiro Lobato e com Wagner Cerqueira o texto A Serpente, de Nelson Rodrigues. Esses núcleos de trabalho avançavam satisfatoriamente, mas, em virtude da dificuldade de encontrar horários disponíveis para os ensaios esses processos foram interrompidos.

Um novo núcleo surgiu, composto por Helena Semedo, Ignacio Muñoz, Murilo Rocha e Isabella Leonel, meus ex-alunos no Teatro Escola Macunaíma, e o ator capoeirista Jefferson Mathias, que também nos ministrava aula de berimbau e pandeiro. Para esse grupo, decidimos abordar inicialmente uma arte marcial por vez. Essa decisão se deu pelo fato de que, pelas experiências com os outros núcleos, percebemos que a troca de uma arte para a outra, sem que houvesse uma apropriação corporal devida para os atores, fazia com que ficassem confusos durante a improvisação em relação aos elementos que deveriam usar como norteadores de suas criações. Tudo acabava se misturando, e as especificidades das duas artes se perdiam. As experimentações híbridas com ambas as artes começaram a acontecer quando o processo já estava mais avançado e os atores mais seguros do que estavam fazendo. Com esse grupo utilizamos como estímulo dramatúrgico o texto Hamlet, de William Shakespeare.

Convém esclarecer que a escolha dos textos aqui mencionados para integrar às experimentações não teve como critério a relação direta com artes marciais, uma vez que pretendeu-se defender a ideia de que o "aikido" e a "capoeira" podem auxiliar o ator na preparação e criação de uma maneira mais ampla, possibilitando, portanto, que seus elementos sejam usados no trabalho criativo com qualquer texto, independentemente de sua conexão com as culturas afro-brasileira e/ou japonesa. Em virtude de Hamlet ser um texto muito apreciado por mim, decidi que seria interessante experimentá-lo durante a prática desta pesquisa, entretanto, convém esclarecer que não utilizamos o texto em sua integralidade, mas apenas algumas partes selecionadas pelo grupo durante o processo em que serviram como impulso criativo. O resultado prático 
desta pesquisa, portanto, foi o espetáculo Hamlet concebido a partir das experimentações práticas envolvendo o "aikido" e a "capoeira".

Em relação ao modo de se conduzir a pesquisa prática, ou mais especificamente ao método, eu me debatia com algumas questões no início do doutorado. Foi quando em uma das palestras preparatórias para o Programa de Aperfeiçoamento de Ensino (PAE), ministrada pelo Prof. Dr. Ciro Marcondes me deparei com o termo Metaporo em oposição ao termo Método (meta+odos) utilizado recorrentemente no meio acadêmico. Explica Marcondes que o termo Método se prende a um caminhar definido e rígido de pesquisa, que não abre margem para que a imprevisibilidade apareça. Continua explicando que, em substituição, propõe:

Metáporo (meta+poros) que, ao contrário, é uma via que se faz e se desfaz o tempo todo, que escapa, que não tem existência, que é geração contínua. Cada nova pesquisa sugere uma recomposição de procederes. É a chance que os fatos dão ao observador de aparecerem. E que exigem, desse mesmo observador, malícia, astúcia, esperteza, atenção. $\mathrm{O}$ pesquisador abre caminhos, poros, rasga uma passagem, vislumbra, tem insights. (MARCONDES, 2010, p. 9)

A investigação metapórica, portanto, é encaminhada sem limites pré-definidos, sem saber de antemão por onde se pretende passar e aonde exatamente chegar. Naquele instante, em que assistia à palestra, algumas dúvidas se dissiparam, pois percebi o que desejava fazer, esse desbravar de caminhos sem uma rigidez pré-estabelecida. Consequentemente, considerando que tudo está permanentemente em movimento e em transformação, resolvi encaminhar esse projeto de modo que o pensar acontecesse também em movimento, durante o processo. Por essa razão não nos preocupamos em optar por um método específico de trabalho, uma vez que, lidando com pessoas e com criação, entendo que o percurso não possa ser rigidamente definido, a priori, depende de como o processo vai se desenvolvendo e desvelando por si só. Dessa maneira, pretendeu-se nesta pesquisa, deixar a flexibilidade do "aikido" e a malemolência da "capoeira" afetarem o caminho, que foi sendo construído a medida que os caminhantes, atores e diretora, avançavam; de acordo com a necessidade de cada momento as estratégias, os procedimentos e os estímulos se definiam.

Como tudo se desenvolveu na prática, no movimento e na relação entre mim e os atores, muitas vezes sem uma lógica cartesiana, para mim foi difícil registrar todas as experiências por escrito de forma lógica e compreensível, de modo que o percurso desta pesquisa ficasse claro para quem não vivenciou o processo. Assim, iniciei a escrita da 
tese, que passou por várias reestruturações, depois de ter avançado com a prática, a fim de que se conseguisse organizar melhor as ideias e o que foi experienciado.

Toda a pesquisa prática foi acompanhada pelo Centro de Pesquisa em Experimentação Cênica do Ator, Cepeca, do qual faço parte desde seu início em 2007, coordenado pelos profs. drs. Armando Sérgio da Silva, meu orientador, e Eduardo Tessari Coutinho. O Cepeca é um centro de pesquisa oficialmente reconhecido pela Universidade de São Paulo, sediado na Escola de Comunicação e Artes e registrado no CNPQ. Em encontros artístico-pedagógicos que acontecem às quintas-feiras, os "pesquisatores", termo cunhado pelo prof. Armando, apresentam seus processos. A partir das apresentações estabelece-se um diálogo entre os que assistem e quem apresenta, havendo neste momento uma troca extremamente produtiva para ambos os lados. Todas as devolutivas são ouvidas e filtradas pelo "pesquisator" de acordo com as necessidades e encaminhamentos de sua investigação. Além disso, o Cepeca, como um centro ativo, está frequentemente organizando eventos como mostras, viagens e workshops, o que proporciona a seus integrantes a oportunidade de exporem suas pesquisas e aprofundá-las.

Participar do Cepeca e desenvolver a pesquisa do doutorado foram, portanto, duas atividades intrinsecamente conectadas, pois o passo-a-passo prático da investigação foi apresentado no grupo, tendo como parceiros nesse processo todos seus integrantes. Nessa dinâmica, toda a pesquisa desenvolvida neste trabalho foi, portanto, acompanhada de perto pelo Cepeca que, a partir das apresentações de meus processos, contribuíam com comentários que corroboravam a percepção e aclarava-me às ideias e o que havia necessidade de ser mais bem trabalhado e elucidado. A etapa inicial desta pesquisa foi publicada no livro Cepeca: uma oficina de pesquisatores $2 \mathrm{em}$ novembro de 2014.

Além disso, o Cepeca possibilitou que eu apresentasse o processo que eu desenvolvia em eventos tais como a Mostra Experimentos, realizada anualmente no TUSP; as duas Mostras Cepeca, realizadas no Teatro Escola Macunaíma e em Mogi das Cruzes; e o Projeto Intercâmbios que aconteceu em parceria com diversos países da América Latina, organizado pelo prof. dr. Eduardo Tessari Coutinho. Todas as interferências desse Centro e as trocas com outras pessoas estranhas à pesquisa em eventos diversos que participei colaboraram para encaminhar a investigação, pois se tratava de um olhar de outra perspectiva. 
No intercâmbio com a América Latina que se realizou entre agosto e setembro de 2014 e em companhia de outros integrantes do Cepeca, o prof. dr. Eduardo Coutinho, prof. dr. Ipojucan Pereira da Silva e profa. Vanessa Bruno, tive a oportunidade de ir para Costa Rica e México para desenvolver algumas atividades explicitadas a seguir:

Ministrei a oficina intitulada "A capoeira como inspiração para o trabalho do ator" na Universidade da Costa Rica (UCR), São José, em que experimentei com um grupo de cerca de vinte alunos da graduação procedimentos práticos que vinha desenvolvendo nesta pesquisa. Esse encontro com os alunos foi bastante produtivo, pois, ajudou a clarear e organizar ideias e procedimentos que eu havia começado a colocar em prática nos ensaios em São Paulo. A partir dessa interação descobri novas possibilidades para abordagem dos elementos que estava utilizando e pude experimentar novos procedimentos. As vivências produziram algumas alterações nos rumos dos ensaios com os atores em São Paulo, o que deu uma maior impulsão nos trabalhos práticos de criação.

Apresentei no Teatro Universitário da UCR para uma plateia lotada, em sua maioria de alunos e professores da UCR, o espetáculo Separação de Corpos. Ao final da apresentação houve um bate papo com os presentes em que tive a oportunidade de explicitar o processo de criação deste trabalho. Nesse bate-papo pude responder questões relativas tanto ao processo criativo quanto à pesquisa como um todo.

$\mathrm{Eu}$, juntamente com os demais participantes do projeto Intercâmbios, participei da Cátedra, atividade organizada pela UCR que tem como objetivo promover um diálogo entre os pesquisadores do Cepeca e os alunos e professores da UCR sobre nossas pesquisas, explanando mais detalhadamente o que e de que forma elas aconteciam.

$\mathrm{Eu}$, juntamente com os demais participantes desse projeto, participamos de um evento semelhante à Cátedra da UCR, em Pachuga, Hidalgo, no México em que tivemos a oportunidade de encontrar alunos e professores da Universidade Estadual de Hidalgo para partilhar nossas investigações.

$\mathrm{Eu}$, juntamente com os demais participantes do projeto, tive a oportunidade de encontrar vários professores da UNAM, Universidade Autônoma do México, e conversar sobre a organização e o funcionamento do Cepeca e as pesquisas desenvolvidas pelos integrantes. Com um dos professores, Miguel Angel Barrera, estabeleci especial conexão por ser ele responsável pela disciplina Combate Cênico. Miguel desenvolve uma pesquisa de preparação dos atores a partir das técnicas de luta 
com espada, buscando a transposição destas técnicas para o aprimoramento da postura e da presença cênica. Neste encontro pude explicar como estava encaminhando a parte teórica e prática da minha investigação e ouvir dele como estava sendo delineada sua pesquisa. Foi um bom momento de troca.

Além dos eventos ligados ao Cepeca, pude expor minha pesquisa individualmente em outros encontros acadêmicos como o Seminário de Pesquisa em Andamento, SPA, organizado pelo corpo discente na Universidade de São Paulo, tendo participado do $3 .^{\circ}, 5^{\circ}$ e $6^{\circ}$ SPA e o Simpósio Reflexões Cênicas Contemporâneas realizado na Unicamp em 2016.

Desse processo de compartilhamento de pesquisa pude também contribuir com algumas publicações de artigos como: $O$ "aikido" e a "capoeira" como fontes de inspiração para a dramaturgia do ator, Revista Aspas; $O$ "aikido" e a "capoeira" como inspiração para o trabalho do ator, Revista Rascunhos; e $O$ aikido e a capoeira como fontes de inspiração para o trabalho do ator, Anais do Simpósio Reflexões Cênicas Contemporâneas.

Acrescento ainda que foi muito útil ao meu processo de pesquisa ter participado do PAE, Programa de Aperfeiçoamento de Ensino, em que estive sob a supervisão do prof. dr. Eduardo Tessari Coutinho, que além de me dar a oportunidade da vivência na docência de graduação, pude usar em alguns momentos elementos da minha pesquisa de doutorado, aprofundando-a. Nesse aspecto a parceria com o prof. Coutinho foi muito positiva, em que foi proposto por ele um plano de aula onde tive espaço para aplicar alguns procedimentos que estava desenvolvendo visando a autoconscientização corporal e a relação com o parceiro, de modo que os alunos pudessem aprimorar seu trabalho "atoral" e experimentar-se em cena a partir de diversas linguagens. Neste ponto, acredito que a minha participação foi importante, pude contribuir com algumas propostas que potencializaram o que foi planejado pelo professor Coutinho, uma vez que minha pesquisa de doutorado envolve a dramaturgia do ator, ou seja, o aprimoramento do trabalho do ator por meio do corpo como um todo, visando especialmente a estimulação de seu trabalho criativo na cena.

Todas as experiências descritas acima foram muito positivas para o andamento da pesquisa, nas quais a fim de explicar o que fazia durante a prática tive que reorganizar pontos importantes, tornando mais claro e mais compreensível o meu discurso em relação a minha própria pesquisa. Foi também uma experiência pedagógica importante no sentido de ensinar para os alunos o que é uma pesquisa em teatro e como 
ela pode ser realizada. As perguntas feitas pelos alunos da graduação me fizeram refletir sobre o que eu estava fazendo no momento e repensar alguns encaminhamentos.

Pelo que foi aqui exposto, percebe-se que esta pesquisa foi encaminhada de forma teórica e prática concomitantemente. $\mathrm{Na}$ medida em que os estudos teóricos avançavam, os trabalhos práticos se desenvolviam, de modo que um desse suporte para o outro. Portanto, não seria possível tratá-los separadamente já que se interseccionaram durante todo o processo. Por esta razão os capítulos que se seguem têm conteúdo de natureza teórico-prática e buscam tornar claro o caminho realizado pelos participantes nessa pesquisa.

No primeiro capítulo exporemos o conceito de corpo e explicaremos a forma como ele é abordado ao longo da tese, apresentando as principais referências teóricas utilizadas como Merleau-Ponty e Alva Noe. Entender como o corpo é entendido nesta pesquisa é importante, pois isto tem relação direta com o processo criativo que foi desenvolvido.

No segundo capítulo trataremos do termo "dramaturgia" e de como ele está sendo entendido e aproveitado nesta pesquisa a fim de tornar claro o que queremos dizer com dramaturgia do ator. Conforme será explicitado ao longo do texto, não compreendemos dramaturgia apenas como o texto literário escrito pelo autor, mas como todos os elementos que envolvem a construção de uma encenação como movimento e voz dos atores, figurino, iluminação, dentre outros.

No terceiro capítulo abordaremos o contexto cultural e técnico da "capoeira" de modo a situar o leitor basicamente sobre esta arte. Não se pretende nesse capítulo esgotar o assunto e nem elaborar um manual que oriente a prática, mas apenas abordar o que entendemos como principais elementos presentes na "capoeira" e que utilizamos para a elaboração dos procedimentos práticos. Chamamos de procedimentos práticos todos os exercícios realizados com os atores voltados para a preparação e a estimulação criativa e expressiva.

No quarto capítulo apresentaremos o contexto cultural e técnico do "aikido" a fim de que o leitor se familiarize com a dinâmica desta arte. Da mesma forma que no capítulo anterior, não se pretende tratar exaustivamente do assunto, mas apenas apresentar ao leitor os principais aspectos dessa arte a fim de que compreenda os caminhos percorridos pelos envolvidos durante toda a etapa prática.

No quinto e último capítulo falaremos sobre o treinamento elaborado para o trabalho com os atores, visando à preparação, à instauração de relação e à estimulação 
criativa por meio do jogo e da improvisação, apoiados nos princípios extraídos das artes marciais estudadas. Nesse capítulo focaremos mais especificamente o trabalho do ator e a forma como os elementos extraídos do "aikido" e da "capoeira" afetaram a elaboração dos procedimentos práticos. Nesse capítulo serão também apresentados o suporte teórico que foi utilizado para o desenvolvimento da prática e a descrição do processo de criação de algumas cenas a fim de que fique clara a relação entre as artes marciais estudadas e o trabalho do ator. As referências teórico-práticas dessa fase foram: Rudolf Laban e sua pesquisa sobre os fatores de movimento; Alva Noe e seu trabalho sobre a percepção; Viola Spolin, que desenvolveu uma vasta pesquisa sobre jogos como recurso para desenvolver a criatividade, a espontaneidade e a prontidão; e Martin Buber, que elaborou as palavras princípio Eu-Tu e eu Eu-Isso para explicar as relações diretas, recíprocas e imediatas. Nesse capítulo trataremos ainda da ritualidade encontrada no "aikido" e na "capoeira" e da forma como ela afetou o trabalho dramatúrgico dos atores. Em ambas as artes marciais pesquisadas, encontramos elementos ritualísticos que permeiam a prática desde inícios cerimoniosos até códigos culturais bem definidos que são seguidos pelo coletivo objetivando alcançar uma unidade e um estado diferenciado do cotidiano. Pretendemos esclarecer de que forma esses elementos contribuíram para a preparação e estimulação dos atores. Por fim, ao longo de todo esse capítulo descreveremos todo o trabalho prático e teórico realizado durante a pesquisa de modo a deixar claro o percurso por nós percorrido.

Nas Considerações Finais procuro amarrar o que foi exposto durante todo o texto, não de forma a concluir como se o trabalho estivesse pronto e terminado, mas apontando caminhos e possibilidades para uma continuidade, um prolongamento, já que entendo esta pesquisa como algo em permanente movimento e de eternas descobertas. Da mesma forma, a finalização do espetáculo concebido durante esta pesquisa é apenas o começo de um novo ciclo que pode trazer ainda muitas outras possibilidades investigativas. 


\section{Capítulo I - O corpo}

Antes de começar a discorrer profundamente sobre o desenvolvimento desta pesquisa, considero conveniente tratar primeiramente a respeito de um termo que é recorrente neste trabalho e que, em grande parte, será a chave para a compreensão do leitor de muito do é aqui exposto, o corpo.

Consideramos o corpo, primeiramente, como um todo formado por partes física e psíquica, ou seja, como algo que não se compõe apenas do que podemos ver e tocar, tais como braços e pernas, mas também de todos os elementos internos conectados a todo o aparato físico: emoções, sentimentos, pensamentos, memórias, imagens mentais e demais atividades internas, sem divisões ou fragmentações. Convém neste ponto tecer alguns comentários sobre os termos apontados acima. A imagem mental é definida por Damásio, 2013, como um:

(...) padrão mental com uma estrutura construída com os sinais provenientes de cada uma das modalidades sensoriais - visual, auditiva, olfativa, gustatória e somatossensitiva. A modalidade somatossentitiva inclui várias formas de percepção: tato, temperatura, dor, muscular, visceral e vestibular. (DAMÁSIO, 2013, p. 402)

A imagem produzida pela mente é, portanto, uma representação interiorizada de algo que passou em algum momento pela percepção do sujeito. Esta representação, entretanto, não é uma cópia do real, mas uma forma de cada sujeito se apropriar das informações que internalizou. O fluxo dessas imagens Damásio define como pensamento. Explica ainda que as imagens são construídas pela mobilização de objetos que é um estímulo de fora para dentro ou pela memória que é um estímulo de dentro pra fora. Produzimos imagens de forma incessante, inclusive quando estamos dormindo (DAMÁSIO, 2013). Por esta explicação, entendemos que, se a produção de imagens está ligada ao movimento e pensamento ela pode ser concebida como fluxo de imagens, assim, o pensamento está inevitavelmente ligado ao movimento. Corroborando esta ideia, Katz, 2005, traz outros estudiosos do assunto que apontam para o pensar durante a ação, conectando-o à dinâmica do corpo como um todo. Cita, portanto, Rodolfo Llinás, que explica o pensamento como movimento internalizado; e Charles Pierce, que associa o pensamento ao sistema sensório motor e a ação. Já em relação à memória podemos dizer que nosso cérebro funciona a partir de três sistemas de memória independentes. Katz, 2005, explica esse fenômeno expondo que um desses sistemas guarda 
informações autobiográficas, o outro tudo o que vamos aprendendo ao longo da vida e o terceiro armazena os dados que nos possibilita agir automaticamente. Quando as informações circulam de um sistema para outro, as células nervosas vão se alterando nesse processo, o que prova que o cérebro está em constante movimento.

Tratando de emoção e sentimento, podemos recorrer a Damásio, 2003, para entendê-los. Ele define emoção como um programa de ações, algo que se desenvolve em ações sucessivas. Emoção, portanto, para esse neurocientista, não está relacionada à mente, mas ao corpo como um todo (músculo, pulmões, sistema endócrino etc.) em pequenas ações. Já sentimento é uma experiência mental a partir do que está se passando com o corpo. Segue expondo que:

Nós tendemos a acreditar que o que está escondido é a fonte do que é expressado. (...) Esta visão é incorreta. (...) Na verdade os sentimentos é que são basicamente sombras da expressão externa das emoções. (...) Nós temos emoções primeiro e sentimentos depois ${ }^{3}$. (DAMÁSIO, 2003, p. 29-30)

Assim, a grande diferença entre emoção e sentimento, é a de que, respectivamente, um é comportamental e o outro mental, e que, sendo a emoção resultado da reação a uma experiência vivida, esta se dá em primeiro lugar. Todos esses processos são possíveis por causa da percepção - canal de entrada do conhecimento -, pois é por meio da experiência perceptiva que temos acesso às informações, o que faz com que consigamos agir nos ajustando a cada circunstância. "Em termos de percepção, (...) no momento que a informação vem de fora e as sensações são processadas no organismo, colocam-se em relação. É quando o processo imaginativo se desenvolve" (DAMÁSIO, 2005, p. 64). Podemos entender, portanto, que a percepção não se refere ao mundo em geral, mas, apenas àquelas coisas ou pessoas com as quais o sujeito se relaciona, que atraem seu interesse, e neste momento são percebidas por ele.

Percebemos a partir do exposto uma forte interação entre os elementos físicos e psíquicos que formam o corpo. Quando penso, meu corpo inteiro pensa, quando algo me afeta emocionalmente, todo o aparato físico reage em unidade, assim, um simples

3. "We tend to believe that the hidden is the source of the expressed. (...) That view is incorrect. (...) It turns out that it is feelings that are mostly of the external manner of emotions.(...) We have emotions first and feelings after. (...)" 
gesto provoca uma afetação interna correspondente. Por esta razão, é conveniente dizer que pensamos com o corpo todo. Merleau-Ponty, 1999, explica que: "Estou em meu corpo, ou antes, sou meu corpo. (...) Nós mesmos somos aquele que mantém em conjunto esses braços e essas pernas, aquele que ao mesmo tempo os vê e os toca" (MERLEAU-PONTY 1999, p. 208). O ser humano, a partir dessa concepção, é, portanto, um todo indivisível que pensa, age e sente simultaneamente.

Por essa explicação identificamos outro aspecto para completar o conceito de corpo: o mundo que envolve este corpo. Para explicar este processo usaremos dois termos desenvolvidos por Merleau-Ponty que são "corpo-vivo" lived-body e corporeidade. Para esse filósofo, o homem só pode ser entendido a partir das relações que estabelece com o entorno e, para tanto, utiliza o termo "corpo-vivo" que é o corposubjetivo, que experencia, que vivencia o que acontece a seu redor, e que torna possível a percepção do mundo e a ação sobre ele por meio de suas funções sensório-motoras. Acerca do estar no mundo, Merleau-Ponty assinala:

(...) enquanto tenho um corpo e através dele ajo no mundo, para mim, o espaço e o tempo não são uma soma de pontos justapostos, nem tampouco uma infinidade de relações das quais minha consciência operaria a síntese e em que ela implicaria meu corpo; não estou no espaço e no tempo, não penso o espaço e o tempo; eu sou no espaço e no tempo, meu corpo aplica-se a ele e os abarca. (MERLEAUPONTY, 2006, p. 194-195)

Temos, portanto, que o ser humano deva ser compreendido em toda sua complexidade psicofísica e pelas inter-relações que estabelece com o mundo externo. $\mathrm{O}$ "corpo-vivo" é, por consequência, resultado do processo de interação com o entorno, uma vez que todos os elementos que foram percebidos por ele, passam a integrá-lo de alguma maneira. Essas interações são de natureza biológica, afetiva, cognitiva, histórica, cultural, estética, lúdica, linguística, dentre outras que compõem o ambiente frequentado por este ser. Para Merleau-Ponty “o homem está no mundo, é no mundo que ele se conhece (...) é sujeito consagrado ao mundo" (MERLEAU-PONTY 1999, p. 6). E segue explicando que “(...) mundo é não aquilo que eu penso, mas aquilo que eu vivo; eu estou aberto ao mundo, comunico-me indubitavelmente com ele, mas não o possuo, ele é inesgotável” (Idem, p. 14).

Concluindo que ao estudar o corpo, podemos dizer que não é possível compreendê-lo separado do ambiente que o circunda. O corpo está em constante processo, nunca acabado, se transformando incessantemente por meio do contato com o 
que o envolve. "O corpo anatômico e o corpo vivo atuando no mundo, tornaram-se inseparáveis. (...) Não é apenas o ambiente que constrói o corpo, nem tampouco o corpo que constrói o ambiente. Ambos são ativados o tempo todo" (GREINER 2005, p. 4243). Temos, por consequência, que não se trata de instâncias diferentes, mas de diferentes dimensões de um mesmo corpo que é vivo e que está constantemente interagindo e em constante processo. O corpo, portanto, não é, mas está sendo.

É sob esses aspectos que entendemos o que vem a ser corporeidade. Corporeidade se refere ao corpo vivo que por meio de seus sentidos e de suas funções motoras entra em contato com o ambiente e se relaciona com ele. Nesse sentido, Merleau-Ponty pontua:

(...) meu corpo é não uma soma de órgãos justapostos, mas um sistema sinérgico do qual todas as funções são retomadas e ligadas no movimento geral do ser no mundo (...) quando digo que vejo um som quero dizer que, à vibração do som, faço eco através de todo o meu ser sensorial e, em particular, através desse setor de mim mesmo que é capaz das cores. (MERLEAU-PONTY, 1999, p. 313- 314)

Esse filósofo defende que, quando ouço uma música não é apenas minha audição que está sendo ativada, assim como não é só a visão que é acessada quando vejo uma cor. Todo o sistema corporal trabalha em conjunto, cada estímulo ecoa e reverbera por todo ele. Por isso, uma cor pode tanto despertar um cheiro, uma memória como um tremor físico.

Em todo o exposto, percebe-se que um há elemento o tempo todo presente, desde quando tratamos dos processos internos do corpo quanto os externos, quando nos referimos à relação com o mundo: o movimento. Se o corpo como um todo está em ação a cada experiência perceptiva e essa experiência pressupõe uma interação com o ambiente, o movimento está presente inevitavelmente. E por consequência, se esta experiência perceptiva promove transformações internas provocando alterações de emoção e sentimento e criando fluxos de imagens, então o movimento também, neste caso, deve ser considerado. Para Merleau-Ponty sem a intencionalidade do movimento o processo perceptivo é menos potente. A cerca disso ele explica:

Não é o sujeito epistemológico que efetua a síntese, é o corpo, quando sai de sua dispersão, se ordena, se dirige por todos os meios para um termo único de seu movimento, e quando, pelo fenômeno da sinergia, uma intenção única se concebe nele. (MERLEAU-PONTY, 1999, p. 312) 
Assim, quando o ser humano se relaciona com o entorno, não é apenas uma parte dele que faz o processamento de tudo que internalizou perceptivamente, mas todo seu corpo durante o movimento. Os movimentos, as ações, as interações com os objetos que o cercam situam o corpo no mundo de modo que tudo tenha significado para ele. Explicando esse fenômeno Merleau-Ponty (1999, p.23), ressalta que o homem sente na exata medida em que coincide com o sentido, instante em que ele deixa de estar situado no mundo objetivo. Ou seja, a partir do momento em que o corpo entra em contato com o mundo por meio de sua faculdade sensorial, esse mundo deixa de ser um objeto de análise objetiva para ele passando a fazer parte de sua subjetividade. Como os sentidos não atuam de forma linear e uniforme, mas de maneira dinâmica, estabelecendo diferentes conexões entre si, de acordo com o momento vivenciado, cada corpo terá uma forma particular de perceber cada situação. Em outras palavras podemos dizer que, diante de um mesmo objeto, cada pessoa o perceberá de forma pessoal e única. Assim, no processo do ser no mundo ele também cria e não apenas absorve informações. Acerca dessa noção, Marco de Marinis, tomando como referência Pitozzi, estabelece uma distinção:

(...) entre o corpo como uma categoria universal e a corporeidade como uma experiência singular. (...) A vantagem da adoção do conceito de corporeidade (...) está no fato de que ela permitiria uma maior conscientização, graças a uma abordagem fenomenal para $o$ corpo. (DE MARINIS, 2012, p. 6)

Aqui De Marinis reforça a individualidade da experiência de cada pessoa, levando-se em consideração a forma como cada uma processa as diversas vivências as quais está sujeito. A ideia de que cada corpo, em sua complexidade, passa por experiências singulares tendo em vista suas particularidades, reforçando o processo de criação constante na interação com o mundo. Assim, ao mesmo tempo em que os corpos estão se relacionando entre si e com o ambiente, cada um tem seu movimento próprio, sua estrutura, suas sensações que o diferencia dos demais. Todo o processo, de acordo com esse pesquisador, conduz a uma autoconscientização maior, tendo em vista que o olhar sobre as próprias afetações passa a ser mais apurado.

Esse raciocínio se deve ao fato de Merleau-Ponty ter rompido com as concepções de corpo-objeto e dos sentidos como receptores passivos. Trata-se, portanto, do corpo encarnado que sente, olha, vê, ouve e, experenciando o mundo, interage com o 
entorno que não é apenas um espaço vazio prestes a ser preenchido pelo corpo, mas expressivo. Merleau-Ponty segue explicando que:

O espaço não é o ambiente (real ou lógico) em que as coisas se dispõem, mas o meio pelo qual a posição das coisas se torna possível. Quer dizer, em lugar de imaginá-lo como uma espécie de éter no qual todas as coisas mergulham, ou de concebê-lo abstratamente com um caráter que lhes seja comum, devemos pensá-lo como a potência universal de suas conexões. (MERLEAU-PONTY, 1999, p. 328)

E é na interação constante do corpo vivo com o mundo repleto de possibilidades que o espetáculo da vida se desenvolve e se recria o tempo todo. Cada objeto tocado, cada passo dado, cada coisa sentida abre uma enorme quantidade de possibilidades que não são apenas racionalmente compreendidas, mas vividas, percebidas e sentidas. $\mathrm{O}$ trecho abaixo deixa claro o processo que se dá com o ser humano na relação dinâmica entre a sua complexidade psicofísica e o ambiente que o circunda:

Meu corpo tem poder sobre o mundo quando minha percepção me oferece um espetáculo tão variado e tão claramente articulado quanto possível, e quando minhas intenções motoras, desdobrando-se, recebem do mundo as respostas que esperam. Esse máximo de nitidez na percepção e na ação define um solo perceptivo, um fundo de minha vida, um ambiente geral para a coexistência de meu corpo e do mundo. (MERLEAU-PONTY, 1999, p. 337)

Esse filósofo, nesse trecho, reforça a participação ativa de cada um no mundo em que vive. A variedade e a riqueza do espetáculo a volta de cada pessoa será percebida de forma mais ou menos potente, de acordo com o grau de nitidez da percepção do que o envolve. Esse trabalho apurado dos sentidos define esse "ser no mundo".

Contemporaneamente, diversos outros filósofos aproveitaram alguns aspectos da obra de Merleau-Ponty e desenvolveram suas teorias no que diz respeito ao conceito de corpo e sua conexão com o que o cerca. Um deles é Alva Noe. Ele explica que "o corpo dá estrutura e forma para os tipos de relação que nós podemos ter com o mundo a nossa volta; o mundo surge para nós graças a nossa habilidade corporal de coordenar nossa relação com ele" (NOE, 2009, p. 65). Continua expondo ainda que "a consciência não é algo que alcança por si só. A consciência exige uma operação conjunta do cérebro,

4. "the body gives structure and shape to the kinds of relations we can have to the world around us; the world shows up for us thanks to our bodily ability to coordinate our relation to it." (NOE, 2009, p.65) 
corpo e mundo. Na verdade, a consciência é uma conquista do animal como um todo em seu contexto ambiental" ${ }^{5}$ (Idem, p. 19). Sendo assim, tudo o que se faz, o estado emocional, os ciclos do sono, os exercícios realizados, o que se vê, ouve e cheira, afetam o cérebro e o transformam (NOE, 2009).

Nos trechos apresentados acima, Noe deixa claro que, em seu entendimento, obviamente temos um cérebro, mas este cérebro não é o único responsável pela formação da consciência e, ao contrário, ele participa nesse processo juntamente com as demais partes do corpo, ressaltando ainda a relação deste corpo com o ambiente que o envolve. Esse é um ponto crucial na teoria desenvolvida por Noe, ele não concebe o homem destacado do mundo em que vive; a consciência não é algo que acontece dentro de nós, mas ao contrário, é algo que acontece ativamente na relação do homem com o mundo. Portanto, a consciência está relacionada ao que fazemos a partir da conexão com o que nos cerca. Assim, os animais, os homens incluídos, são agentes que têm seus interesses, desejos, necessidades e, portanto, agem a fim de cumprir seus objetivos. Entretanto, esses interesses estão intrinsecamente conectados ao contexto em que estão inseridos. Dessa forma, não é possível entender a vida de um ser sem levar em consideração sua perspectiva ecológica e cultural. A respeito disso, Noe expõe:

Mente é vida. Se nós queremos entender a mente de um animal nós não deveríamos olhar apenas para seu interior, para sua constituição neurológica e física; nós também devemos prestar atenção a maneira do animal viver, sua forma de se envolver com seu espaço. ${ }^{6}$ (NOE, 2009, p. 42)

Assim, pensamos que para se entender o animal, faz-se necessário olhar tanto para seu interior como para o que é externo a ele, concluímos que o ser vivo possui uma natureza plástica e moldável pela vivência, ou seja, por tudo o que é experenciado ao longo da vida. Portanto, se somos resultado da conexão com o que nos cerca, ao se alterar o entorno, altera-se também o que somos. Esta concepção dialoga com a de

5. "Consciousness is not something the brain achieves on its own. Consciousness requires the joint operation of brain, body, and world. Indeed, consciousness is na achievement of the whole animal in its environmental context." (NOE, 2009, p. 19)

6. "Mind is life. If you want to understand the mind of an animal, we should look not only inward, to its physical, neurological constitution; we also need to pay attention to the animal's maner of living, to the way it is wrapped up in its place." (NOE, 2009, p. 42) 
Merleau-Ponty, haja vistas, que também para esse filósofo, mudanças na experiência do "corpo vivo" acarretam alterações na consciência de mundo.

Outro aspecto necessita ser esclarecido a respeito do corpo, para melhor compreensão desta investigação: a corporalidade. Nesta pesquisa entendemos corporeidade e corporalidade como conceitos diferentes. Para este trabalho, a corporeidade pode ser definida como o fenômeno de conexão do homem com o mundo por meio de suas faculdades psicofísicas, e, a corporalidade é entendida como a resultante corporal dessas experiências. Portanto, se um corpo vive determinadas experiências, ele vai se moldando e se ajustando ao que foi vivido. $\mathrm{O}$ que se entende quando olhamos para este corpo impregnado dessas experiências é o que chamamos, nesta pesquisa, de corporalidade. Tomando como exemplo o "aikido" e a "capoeira", quando observamos estas artes em movimento nos corpos de seus praticantes, identificamos em cada uma delas características muito particulares em razão da forma como cada uma se expressa. Essa forma diferenciada de expressividade gera uma corporalidade específica que demarca cada uma dessas artes marciais. A corporalidade, portanto, seria a corporificação da experiência, a forma como um corpo é "construído" a partir do que viveu com seus músculos, seus sentidos, sua mente, seus movimentos, enfim, com todo seu aparato psicofísico.

Pensando no trabalho do ator, diversos pesquisadores do teatro trabalham a partir dessas concepções de corpo expostas acima entendendo que "eu sou este corpo" em vez de "eu tenho este corpo". Ferracini, 2003, por exemplo, corroborando essa ideia, fala do termo "corpo em vida" explicando que:

Não é simplesmente seu corpo, mas seu "corpo-em-vida", como diz Eugênio Barba. Um "corpo-em-vida" é um corpo em constante comunicação com os recantos mais escondidos, secretos, belos, demoníacos e líricos de nossa alma. É o receptáculo da poesia do teatro. O ator é um "atleta afetivo", como diz Artaud. (FERRACINI, 2003, p. 37)

Peter Brook complementando esse raciocínio diz que "ser sensível para um ator significa estar permanentemente em contato com a totalidade de seu corpo" (BROOK, 2002, p. 17). Essa conexão psicofísica está presente também no trabalho de Stanislavki, Meyerhold e tantos outros que partem da indissociabilidade dos aspectos físicos, psíquicos, emocionais e intelectuais do corpo. Todos esses pesquisadores, para organizar seus trabalhos artísticos, entendem o artista como um ser composto de uma 
complexidade de dimensões e que, compreendendo esse processo, seu trabalho pode ser mais potente e completo.

De Marinis a esse respeito argumenta que "a relação teatral coloca em jogo o corpo assim como a mente, os músculos não menos que o pensamento, os sentidos e os nervos pelo menos tanto quanto a imaginação e a emoção" (DE MARINIS, 2012. p. 3). Esse pesquisador reforça a importância da compreensão do corpo como um todo, apontando que o ator, durante seu trabalho, lança mão de todos os seus recursos psicofísicos para potencializar sua expressividade e sua criação.

Nesta pesquisa, portanto, pretendemos encaminhar o trabalho prático com os atores de modo que todos seus aspectos psicofísicos sejam levados em consideração, tanto na etapa de preparação quanto de criação, uma vez que, todas as partes do corpo se afetam mutuamente e se transformam na relação constante com o ambiente. E, como resultado deste processo, pretendemos chegar a uma corporalidade específica, fruto de todas as experiências vivenciadas durante o processo. 


\section{Capítulo II. Dramaturgia}

Esta pesquisa visa, como resultado final, a concepção de um espetáculo que tenha sua dramaturgia construída durante o processo prático com os atores. Entendemos como dramaturgia a concepção exposta por diversos pesquisadores em teatro, como Bertold Brecht, Antonin Artaud e Eugênio Barba, que as apresentam não apenas como a obra resultante da escrita de um texto, de natureza literária, mas como uma obra composta por diversos elementos que compõem a cena. Essa compreensão mais ampla sobre dramaturgia muito se deu pela influência do teatro oriental que via todos os elementos cênicos como autônomos e expressivos, não dependentes de um texto previamente elaborado. A partir dessa influência do teatro oriental, inclusive japonês:

Emerge no ocidente uma noção de dramaturgia vista enquanto operação através do qual elementos cênicos não convergem para um mesmo ponto, mas são entrelaçados de diversas maneiras, são "tecidos". Surge assim, de maneira mais consistente em algumas culturas do Oeste, a noção de "dramaturgia como textura". (BONFITTO, 2013, p. 202)

De acordo com essa noção, a manifestação teatral resultaria de uma inter-relação de diversos elementos, desde figurinos e cenários, até ações, palavras, movimentos, e qualquer tipo de criação proveniente do trabalho do ator. Eugênio Barba, 1995, seguindo esta noção, explica o termo "texto" como "tecer junto". Segundo esse diretor, o texto teatral pode ser definido como dramaturgia que vem de drama-ergon, ou seja, trabalho das ações, que não está ligada unicamente a literatura dramática, nem se refere somente às palavras ou a trama narrativa. Barba segue explicando que existe também uma dramaturgia orgânica ou dinâmica, que orquestra os ritmos e os dinamismos que afetam o espectador a um nível nervoso, sensorial e sensual. Cada cena, ação, sequência, fragmento do espetáculo possui uma dramaturgia própria; assim, pode-se dizer que dramaturgia é, portanto, uma maneira de pensar. Barba explica ainda que se trata de uma técnica que nos permite organizar os materiais para poder construir, desvelar e entrelaçar relações. É o processo que nos permite transformar um conjunto de fragmentos em um único organismo no qual os diferentes elementos não podem se distinguir como objetos ou indivíduos separados.

A esse respeito Rufini, 1993, explica que dramaturgia pode ser entendida como trabalho, a partir do próprio conceito de física que define o termo como uma fase intermediária entre a energia e o movimento, ou seja, a energia expressa a capacidade 
para realizar um trabalho que resulta no movimento. Compreendida assim, a dramaturgia seria, consequentemente, o filtro que faz com que a energia tome forma em movimento. Segue expondo que são as ações que realizam o trabalho a partir do texto, dos atores ou dos demais elementos que compõem a cena como luz, objeto etc.

É a essa dramaturgia, que entrelaça todos os elementos cênicos, que nos referimos nesta pesquisa, de modo que toda a criação parta da vivência prática dos atores. Essa criação "atoral" teve como principal preocupação a organicidade das ações tendo como ponto partida a criação do próprio ator, fundamentado nos elementos psicofísicos que o compõem; percebemos que seria mais fácil construir um caminho cênico mais fértil e criativo em que os aspectos externos e internos do corpo estivessem em conexão todo o tempo. A esse respeito Barba em A Canoa de Papel defende que a ação física "deve apoiar-se e fundar-se sobre associações pessoais, íntimas do ator, sobre suas baterias psíquicas, sobre seus acumuladores internos" (BARBA, 1994, p. 164). Dessa forma, objetivou-se obter como resultado desta pesquisa um espetáculo verdadeiramente "atoral", no qual todo o conjunto corporal do ator, incluindo as relações que estabelecesse com os parceiros e os objetos cênicos, fosse responsável pelo "texto teatral da cena".

Seguindo esse conceito, pretendemos criar essa "teia” de ações, falas, respiração, objetos, ritmos e relações por meio da estimulação do corpo do ator em várias dimensões, desde a física, sensorial e intelectual, até a emocional e imagética, recorrendo aos elementos que o "aikido" e a "capoeira" podem proporcionar, de modo que, diferentes realidades fossem moldando a dramaturgia. Quando falamos em diferentes realidades, referimos tanto à realidade mais palpável e concreta, quanto àquela que é percebida por outras formas sensoriais, ainda que seja invisível aos olhos.

Tendo em vista, portanto, que estamos partindo de uma base complexa, subjetiva e repleta de variáveis que é o ator, entendemos este processo de construção dramatúrgica como um rizoma, em que não existe um único caminho certo a ser seguido, mas uma multiplicidade de possibilidades que podem gerar diversos caminhos. Neste trabalho, esta trajetória foi definida ao longo dos ensaios conforme os atores interagiam entre si e se relacionavam com os materiais técnicos e poéticos apresentados, a exemplo do conceito de metáporo apresentada pelo prof. Ciro Marcondes, que substitui o rigor de um caminhar determinado definido por um método, para dar espaço à imprevisibilidade. $\mathrm{O}$ foco desta pesquisa, portanto, não foi contar uma história ou narrar um acontecimento, mas descobrir caminhos que auxiliassem o ator a alcançar 
qualidades expressivas, estados e níveis de energia que os levassem a criar imagens, ações e tipos de relações. E, então, a partir desse material, construir a narrativa.

De acordo com o que foi exposto acerca da dramaturgia, percebe-se a importância da compreensão do que é considerado corpo para nós nesta investigação, pois é a partir desse entendimento que se torna clara a relação entre a criação dramatúrgica e o trabalho do ator, tendo como foco sua estimulação corporal. A respeito da importância da compreensão do corpo como um conjunto psicofísico para o ator, Pavis expõe que:

\begin{abstract}
A busca do sentido deve se efetuar, para o ator como para o espectador do ponto de vista de um corpo-mente, de uma entidade inseparável e não examinando como uma emoção se expressa externamente numa forma ou, inversamente, como uma forma exterior, impressa ao corpo, produz emoção. A formação do ator e sua intervenção cênica consistem em ultrapassar o dualismo para realizar a experiência da unidade entre as dimensões interior e exterior (...) $\mathrm{O}$ corpo-mente convida a fazer, justamente, o caminho entre interioridade e exterioridade em ambas as direções, sem privilegiar uma delas. (PAVIS, 2007 apud CURI, 2013, p. 92)
\end{abstract}

Esse processo não excluiu, entretanto, o uso de textos e outros materiais produzidos por autores externos à pesquisa, porém, foram aproveitados na medida e da forma que os atores desejaram durante a prática. Esses materiais funcionaram, portanto, como elementos no meio de tantos outros que foram utilizados para a potencialização da criação do ator. Assim, identificamos nesta pesquisa uma conexão entre os termos ator e performer, pois, neste caso, o próprio ator, com as suas potencialidades, limitações, vivências, experiências, relações e aprendizados, foi quem deu vida às cenas. Bonfitto, 2013, nesse sentido, ao tratar, tanto no caso do ator como do performer, dos processos que envolvem expansões e deslocamentos de um suposto "Eu" em direção a um suposto "Outro", ressalta a importância da função desempenhada pelo corpo como matéria relacional constitutiva da própria obra, visto como dispositivo psicofísico (BONFITTO, 2013, p. XXII e XXIII). É este potencial relacional que o corpo possui que fará com que o ator conecte todos os elementos vivenciados visando à criação dramatúrgica.

Acerca desse processo, Guillermo Del Peña, explica que:

Tradicionalmente, el cuerpo humano, nuestro cuerpo, y no el escenario, es nuestro verdadero sitio para la creación y nuestra verdadera materia prima. Es nuestro lienzo en blanco, nuestro instrumento musical, y libro abierto; nuestra carta de navegación y mapa biográfico; es la vasija para nuestras identidades en perpetua transformación; el icono central del altar, por decirlo de alguna 
manera. Incluso en los casos en que dependemos demasiado de objetos, locaciones y situaciones, nuestro cuerpo sigue siendo la matriz de la pieza de arte.

Nuestro cuerpo también es el centro absoluto de nuestro universo simbólico - un modelo en miniatura de la humanidad2 (humankind y humanity son la misma palabra en español: humanidad) - y, al mismo tiempo, es una metáfora del cuerpo sociopolítico más amplio. Si nosotros somos capaces de establecer todas estas conexiones frente a un público, con suerte otros también las reconocerán en sus propios cuerpos. (DEL PEÑA, 2005, p. 204)

Pelo exposto, percebe-se que pretendemos nesta pesquisa, no que diz respeito à dramaturgia, traçar um percurso que faça uso tanto da autorreferencialidade como da referencialidade, com os dois se alternando durante todo o processo de criação. Isto porque, ao lançarmos mão de um repertório novo para os atores, que deve ser assimilado por eles, digerido e transformado em material poético a partir de uma percepção pessoal, três movimentos precisam acontecer: o primeiro é de observação e de aprendizado de elementos novos; o segundo é de identificação para que o contato com essas artes desperte todo o aparato psicofísico do ator motivando-o a agir; e o terceiro é de criação a partir do que foi vivenciado durante o processo. Podemos dizer, portanto, que esta pesquisa partiu de uma referencialidade como um estopim psicofísico ou um provocador e se encaminhou para uma autorreferencialidade na medida em que o ator se apropriou de tudo ao que foi exposto de maneira pessoal e subjetiva e o transformou. O envolvimento pessoal sobre os elementos apresentados durante o trabalho foi de extrema importância, pois foi isso que fez com que tornassem possíveis novas descobertas e criações mais ricas. A identificação apontada aqui é explicada por Bonfitto ao citar Motokiyo Zeami e sua obra Kadensho. Zeami explica a identificação, dos princípios da noção de imitação, como sendo a dissolução da separação entre o objeto observado e o sujeito observador, acontecendo "uma fusão entre ator e material, em que o primeiro participa da realidade do segundo vivendo-o" (BONFFITTO, 2013, p. 101). Percebemos nesse processo, portanto, uma transformação mútua entre objeto e sujeito. Neste ponto um aspecto interessante deve ser levantado a respeito do ator e do performer. De forma geral é comum ouvirmos que o performer está ligado à autoria e o ator à representação, de modo que o performer sempre atua a partir dele mesmo e o ator cria algo que está fora dele como um personagem. Entendemos para esta pesquisa que essa diferença empobrece a forma de entender um e outro, pois restringe a possibilidade criativa de ambos. Tendo em vista que as poéticas da cena se hibridizam cada vez mais, não entendemos como proveitosas as definições que "encaixotem" e "rotulem" a 
atuação do ator e do performer, separando-os como artistas em oposição. Não queremos dizer que essas diferenças não existem, mas, enquanto processo criativo, entendemos que a mescla dessas duas linguagens podem ajudar a potencializar o trabalho de uma dramaturgia da cena.

Objetivou-se, portanto, disparar um processo de criação que tivesse como foco o corpo do ator com toda a sua subjetividade, impulsos internos e impressões das experiências vividas de modo que todo esse material se transformasse em ações, em imagens corporais e relações. Foi a partir das afetações e transformações desse corpo que foi se definindo o caminho dramatúrgico construído durante a pesquisa. Pretendeuse nesse processo que o ator tivesse uma participação ativa e que não fosse um simples reprodutor de ideias alheias. Partimos do entendimento que é ele próprio que está na berlinda, se expondo, se entregando, propondo, agindo, se doando, de corpo e alma, com todo seu aparato psicofísico. Convém reforçar que quando falamos do ator se entregando por inteiro a um trabalho de criação, nos referimos a tudo o que o compõe, desde experiências vividas de forma geral em sua vida cotidiana até as vivenciadas em determinado trabalho visando uma preparação específica. A respeito do que se vai aprendendo ao longo da vida, ao se expor a novas situações e ao adquirir novos conhecimentos e habilidades, o ator descobre suas limitações e seus potenciais, percebe seus padrões, identifica características próprias, enfim, passa a se conhecer melhor. Além disso, o ator tem mais material a seu alcance para expressar seus impulsos internos, pensamentos e desejos. Morin explica que:

Para sermos nós próprios, é-nos preciso aprender uma linguagem, uma cultura, um saber e é preciso que esta cultura seja bastante variada para que possamos fazer a escolha no stock das ideias existentes e refletir de maneira autônoma. (MORIN, 2003, p. 96)

E nesse processo em que o corpo vai sendo afetado continuamente, o conhecimento, o aprendizado, as experiências vividas, vão integrando esse corpo e fazendo parte dele. Merleau-Ponty aponta também para este caminho quando argumenta que "Sou meu corpo, exatamente na medida em que tenho um saber adquirido e, reciprocamente, meu corpo é como um sujeito natural, como um esboço provisório de meu ser total" (MERLEAU-PONTY, 2006, p. 268). Ou seja, o corpo nunca é definitivo, ele é sempre um esboço que vai tomando forma enquanto vive e experencia. Temos, portanto, que a mencionada autorreferencialidade vem preenchida de todas as 
informações que vamos absorvendo de forma consciente ou não, ao longo de nossa vida, e que pode auxiliar na ampliação de nossa potencialidade expressiva.

Considerando que estamos estabelecendo as pontes entre esta pesquisa e o trabalho do performer, convém também estabelecer os pontos de contato entre a performance e as duas artes marciais aqui estudadas, a fim de que aprofundemos o entendimento sobre o processo desenvolvido nesta investigação.

Para Schechner as manifestações humanas podem ser entendidas enquanto performance ou como performance. Para ele tudo, desde ações cotidianas até apresentações ritualísticas, pode ser visto enquanto performance, mas não necessariamente ser performance. Segue explicando que a performance pode ser vista por diferentes vieses como "execução, desempenho, façanha, proeza, representação, função, espetáculo, atuação, capacidade de realizar trabalho, rendimento, maneira de reagir ao estímulo, cumprimento de uma promessa equivalente a competência" (SCHECHNER, 2007, p. 28). Estabelecendo uma ponte entre esse entendimento e o "aikido" e a "capoeira", não há como negar que a prática de ambas exige desempenho, proeza, façanha, uma vez que os movimentos exigem habilidades específicas que variam de fácil à dificílima execução. Nos praticantes mais graduados vemos um grande virtuosismo que transcende a questão da luta e do embate físico e vai além. Envolve, dessa forma, uma plástica e estética semelhantes às encontradas em espetáculos de dança e de teatro. Considerando, portanto, performance sob este aspecto, tanto a “capoeira" como o "aikido", podem ser considerados performáticos.

Schechner argumenta também que performance vai além do fenômeno artístico e inclui outros, tais como o cultural, o social, o político, o esportivo, o entretenimento, o ritualístico, sendo, assim, bastante amplo (FERRAL, 2009). Schechner expõe ainda que as performances “(...) marcam identidades, dobram o tempo, remodulam e adornam o corpo, e contam histórias. Performances - de arte, rituais, ou da vida cotidiana" (SCHECHNER, 2007, p. 2). Neste ponto podemos estabelecer outra conexão com o "aikido" e a "capoeira", pois, conforme se verá ao longo deste trabalho, estas duas artes marciais têm como fortes características a questão ritualística e a contextualidade cultural e social fisicalizada e exteriorizada pelos movimentos dos praticantes e pelos objetos utilizados por eles. Ao observarmos um jogo de "capoeira" ou uma demonstração de "aikido", percebemos todo o processo histórico e cultural que fez surgir estas artes marciais afetando e modelando os corpos. 
Toda essa performatividade presente na "capoeira" e no "aikido" foram colocadas a disposição do ator a fim de sensibilizá-lo, provocá-lo, instigá-lo, prepará-lo, transformá-lo, mobilizando-o psicofisicamemente de formas diferentes a fim de potencializar seu trabalho.

Tendo estabelecido, portanto, a co-relação entre nossa construção dramatúrgica, o ator, o performer e a performance, podemos concluir, pelo menos em termos de processo de criação, que este trabalho possui intersecções com o teatro performático. Ferral, ao tratar desse tipo de teatro, começa expondo que, quando tratamos do performer, nos referimos tanto à superação de limites de um padrão, quanto ao engajamento em um espetáculo, em um jogo ou em um ritual. Nesse sentido um performer demanda ao menos as seguintes operações:

1. ser/estar ("being"), ou seja, se comportar ("to behave");

2. fazer ("doing"). É a atividade de tudo o que existe, dos quarks 11 aos seres humanos;

3. mostrar o que faz ("showing doing", ligado à natureza dos comportamentos humanos). Este consiste em dar-se em espetáculo, em mostrar (ou sem mostrar).

Estes verbos (que representam ações), que todo o artista reconhece em seu processo de criação, estão em jogo em qualquer performance. Por vezes separados, por outras combinados, eles não se excluem jamais. Muito pelo contrário, eles interagem com frequência no processo cênico. Performer, no seu sentido schechneriano, evoca a noção de performatividade (antes mesmo da de teatralidade). (FERRAL, 2009, p. 200)

Apoiados nessas operações, ou seja, na ação e no mostrar o que faz, que o processo de criação desta pesquisa aconteceu. Nesse sentido, entendemos que este trabalho, de certa forma, possui algumas características presentes no teatro performático na medida em que o foco está nas ações e não em um texto, performadas por atores que se apresentam como tal, entrando e saindo do estado ficcional em que estiverem criando durante todo o tempo. Além disso, o foco está nas imagens criadas corporalmente pelos envolvidos e não há preocupação em criar um jogo de ilusão, pois todos os elementos usados em cena ficam à vista do público durante toda a apresentação. Esta transição entre estado ficcional e real nos remete a Erika Fischer-Lichte, 2008, em que trata da "multiestabilidade perceptiva" perceptual multistability e da diferença entre presença e representação. Fischer-Lichte argumenta que:

Perceber o corpo do ator em sua corporalidade como ser no mundo estabelece uma ordem de percepção, enquanto entender o ator como representação de um personagem estabelece uma outra. A primeira 
ordem gera significado em torno do ser fenomenal percebido que talvez dispare cadeias de associação, enquanto a segunda ordem produz significado que (...) constitui o personagem. ${ }^{7}$ (FISCHERLICHTE, 2008, p. 108)

$\mathrm{O}$ ator, portanto, se colocando em sua dimensão fenomênica, como ser no mundo, podendo gerar associações e memórias, estaria na ordem da presença. Ao passo que ao se colocar como ser fictício, como um personagem, estaria na ordem da representação. Com esta distinção a autora apresenta estados diferentes de percepção do ator/performer que em um caso é visto como signo e em outro como ser fenomenológico. Não vamos nos aprofundar nas questões da semiótica neste trabalho, mas alguns comentários se fazem necessários a fim de elucidar alguns aspectos desta pesquisa.

Como exposto nesta pesquisa, entendemos que conhecemos e interagimos com o mundo a partir de nossos sentidos. Para que o entendimento sobre o mundo seja possível, recorremos às representações do que estamos vivenciando, ou seja, signos. O signo representa o objeto e é por meio dele que entendemos este objeto. Entretanto, "nenhum signo, por si mesmo, pode ser totalmente preciso justamente por não conseguir cobrir totalmente a extensão de seu objeto. (...) O objeto sempre cresce, se modifica, e modifica seu signo" (KATZ, 2005, p. 21). Temos assim que os movimentos criados pelos atores/performers podem ter uma função sígnica potente moldando o corpo e as relações com o que os cercam de modo a comunicar algo. Katz, 2005, ao tratar da dança, argumenta que o corpo é um ambiente:

(...) onde a dança se instala como fenômeno multidimensional, intersemiótico. Conjunção do físico com o biológico, com o químico, o elétrico, o cerebral, o energético, com o psicológico, individual, o transpessoal, o coletivo, com o mental, o social, o cultural. (KATZ, 2005, p. 100)

Transportando estas ideias para o trabalho do ator e do performer, percebemos também nos movimentos e ações criados por eles, manifestações fenomenológicas multidimensionais e semióticas, em que todo o aparato psico-físico-social reverbera

7. "To perceive the actor's body in his bodily being-in-the-world establishes one order of perception, while understanding the actor as signifying a character establishes another. The first order generates meaning around the perceived's phenomenal being that might trigger chains of association, while the second order produces meaning which (...) constitutes the character." 
impulsos disparados pelo contato com o mundo à volta e que, como consequência, gera signos.

A partir da noção exposta acima, para este trabalho, consideramos o corpo em ambas as ordens perceptivas, de modo que a dramaturgia fosse composta por elementos de presentação e representação, em que o corpo fenomenológico e o corpo sígnico estivessem participando durante o processo. Ou seja, neste trabalho, os atores vivenciaram diversas experiências a partir de estímulos selecionados que despertaram seus sentidos. Este despertar das sensações trouxe movimentos, imagens, relações e, por fim, representações daquilo que estava sendo experienciado. Dessa forma, a dramaturgia foi resultado da experiência do ator em toda a sua subjetividade e da representação dessa experiência por meio dos signos. A cerca disso, Curi argumenta que:

Ao olhar o trabalho do ator (...) na maior parte das vezes a atitude de presentificar se amalgama à de representar. $\mathrm{O}$ intérprete sempre remeterá a alguma referência a priori, seja ela dramatúrgica, material, temática ou mesmo de memória pessoal. Por outro lado, o ator pode atualizar essa referência em seu corpo a cada espaço - tempo de mostra, com sua subjetividade, agregando novas latências àquilo a que sua representação se refere. Isto caracteriza uma atuação entre presentação e representação. (CURI, 2013, p. 69)

Neste processo, o corpo, como principal mídia, atua em diversos níveis, como fisiológico, social, psíquico, cognitivo e fenomenológico, de modo que todas essas dimensões contribuem ora para a criação de uma narrativa, ora para a instauração de uma atmosfera, ora para a apresentação de uma personagem, ora para a expressão do próprio ator desejoso de se comunicar com os demais e com a plateia. Assim, por meio das experiências que o corpo vai tendo ao longo de sua existência, conexões vão sendo estabelecidas que, na construção da dramaturgia, tanto podem dar vazão a uma autoexpressividade mais intensa quanto a uma criação sígnica. Neste caminho, os processos semiótico e fenomenológico estão se potencializando, a fim de que os envolvidos tenham seu potencial criativo e expressivo desenvolvidos. O corpo neste caso está materializando pensamentos e organizando um raciocínio, por meio de ações e movimentos de modo a conseguir um sentido de tudo o que está experienciando. Para Katz “(...) as várias qualidades do movimento que um corpo produz e abriga são todas formas de qualidade de pensamento deste corpo" (KATZ, 1994, p. 24). Esses pensamentos gerados durante o trabalho prático foram aos poucos dando forma à dramaturgia. A respeito desse tema, Christine Greiner argumenta que: 
Para pensar na dramaturgia de um corpo, há de se perceber um corpo a partir de suas mudanças de estado, nas contaminações incessantes entre o dentro e o fora (o corpo e o mundo), o real e o imaginado, o que se dá naquele momento e em estados anteriores (sempre imediatamente transformados), assim como durante as predições, o fluxo inestancável de imagens (...) A dramaturgia do corpo não é um pacote que nasce pronto, um texto narrado por um léxico de palavras, mas como a sua etimologia propõe, emerge da ação. (GREINER, 2005, p. 81)

É essa dramaturgia que emerge de um corpo que foi estimulado, provocado, instigado que buscamos nesta pesquisa. Não houve, portanto, a preocupação de caracterizar um personagem concebido por um autor e nem incorporar coreografias ou marcações definidas por um diretor. $\mathrm{O}$ foco durante todo o tempo esteve sobre o ator/performer que, a partir de sua vivência e na relação com os materiais que lhe foram apresentados, propôs diversas possibilidades de comunicação e de expressão que deu forma ao espetáculo.

Neste processo de criação dramatúrgica não podemos deixar de lado o público, que tem participação importante nesta pesquisa uma vez que partimos da ideia da concepção de uma narrativa a partir das estimulações e afetações sobre o corpo. Da mesma maneira que trabalhamos com a noção de que o artista é afetado pelo seu entorno e que, a partir dessas experiências exerce sua criação, o público também é afetado pelo que assiste e, por isso, está também em atitude de criação. A atividade do público durante a apresentação artística é algumas vezes discreta, outras mais acentuada, entretanto ela sempre está presente. A cerca disso Ranciere, 2008, argumenta que existe um paradoxo no que diz respeito à relação entre público e espectador. Ele explica que, se por um lado não pode haver teatro sem público, por outro lado ser espectador pode ser um mal uma vez que ele desconhece o processo e mantém uma atitude passiva o tempo todo diante do que assiste. Essa assertiva é correta no que diz respeito a alguns tipos de teatro, todavia, contemporaneamente, muito já se experimentou no sentido de colocar o público em posição mais ativa e de deixá-lo mais consciente do fenômeno teatral. Ranciere argumenta a partir disso que:

É preciso arrancar o espectador do embrutecimento do espectador fascinado pela aparência e conquistado pela empatia que o faz se identificar com os personagens da cena. Mostrará a ele um espetáculo estranho, não usual (...). Dessa forma, o forçará a mudar a posição de espectador passivo para de investigador ou experimentador científico 
que observa os fenômenos e indaga as causas. ${ }^{8}$ (RANCIERE, 2008, p.12)

Ranciere, portanto, defende que se diminua o abismo entre os atores e o público fazendo com que este se transforme em um participante ativo do fato teatral. Seguindo essa linha, Spolin, 2003, também reforça a importância do reconhecimento do público durante o acontecimento teatral, como membro participativo do processo artístico. Para ela, quando existe um consenso de que todos aqueles que estão envolvidos no teatro devem ter liberdade pessoal para experienciar, isto inclui a plateia - cada membro da plateia deve ter uma experiência pessoal, não uma estimulação artificial enquanto assiste à peça.

A partir desta ideia pretendemos neste trabalho buscar formas de fazer com que o público seja afetado psicofisicamente de modo que ele seja estimulado a se colocar em atitude de criação e que não se acomode na passividade. Todos os caminhos percorridos nesse sentido nesta pesquisa foram trilhados por elementos extraídos do "aikido" e da "capoeira" que apresentam possibilidades de exploração da voz, do ritmo, dos movimentos, dos objetos, do espaço, das sonoridades, das imagens e das relações, potencializando tanto o ator como o público.

Além disso, um aspecto importante desse processo foi afastar a noção de ilusão e quarta parede, deixando às vistas do público diversos elementos utilizados pelos atores para a composição das cenas. Obviamente isso não é uma novidade no fazer teatral contemporâneo, mas é um procedimento que dialoga fortemente com a dinâmica das artes marciais investigadas nesta pesquisa e faz com que o público se sinta como parte do que está assistindo. A “capoeira”, por exemplo, possui em sua tradição a noção da roda que naturalmente envolve as pessoas que estão no entorno, integrando-as ao que está sendo desenvolvido. O "aikido", por sua vez, em diversos momentos de prática, expõe aos presentes, sejam praticantes ou não, a sua dinâmica sem mascarar o como da realização. Portanto, nada mais natural que manter este foco na pesquisa, tendo em vista

8. "Es preciso arrancar al espectador del embrutecimiento del espectador fascinado por la apariencia y ganado por La empatia que lo hace identificarse com los personages de la escena. Se Le mostrará, pues, um espectáculo extraño, inusual (...) Se lo forzará de esse modo a intercambiar La posición Del espectador pasivo por La del investigador o el experimentador científico que observa los fenómenos e indaga las causas". 
que estamos alicerçados por duas artes que oferecem um material rico para este tipo de trabalho.

Outra questão importante levantada por Ranciere e que dialoga com esta pesquisa diz respeito à recepção pelo público àquilo que assiste. Este autor propõe uma alteração na forma de considerar o olhar do público defendendo que o olhar também é uma ação, e que, portanto, o público também atua. Durante sua ação, ele "observa, seleciona, compara, interpreta"9 (RANCIERE, 2008, p. 19). E nesse processo de ação, da mesma forma que o ator é afetado de forma particular e individual pelo que o envolve e reage, o público vivencia o mesmo processo. Por esta razão, não é possível prever de que forma aquele que assiste a um espetáculo receberá e perceberá a obra teatral, assim como qualquer outra obra artística. Já dissemos que é o corpo que nos conecta com o mundo e que nos faz estar nele, portanto, tendo cada corpo suas próprias características, é natural que cada pessoa se envolva de forma diferente com o que presencia.

Ranciere trata desse assunto ao falar do pedagogo embrutecedor que deseja que seu aluno aprenda exatamente o que está sendo ensinado. Como paralelo a isto está o encenador que quer que o público veja exatamente o que ele está mostrando, como um mecanismo de causa e efeito. Ranciere segue argumentando que entre a ideia do artista e a sensação do espectador existe uma distância que não pode ser controlada por nenhum dos dois. Trata-se de uma terceira coisa "que ninguém é proprietário, que ninguém possui um sentido, que erige entre os dois, descartando toda transmissão do idêntico, toda identidade de causa e efeito" ${ }^{10}$ (RANCIERE, 2008, p. 21). Temos, portanto, que para cada espectador uma obra diferente será apresentada, da mesma forma, que para cada ator um estímulo criativo reverbera de forma diferenciada. A esse respeito Ranciere ainda explica que "os espectadores vêm, sentem e compreendem algo na medida em que compõem seu próprio poema, tal como o fazem a sua maneira os

9. "El espectador también actua, como el alumno o como el docto. Observa, selecciona, compara, interpreta."

10. "Es esa tercera cosa de La que ninguno es propietario, de La que ninguno posee el sentido, que se erige entre los dos, descartando toda transmisión de lo idêntico, toda identidad de La causa y lo efecto." 
atores ou dramaturgos, diretores teatrais, bailarinos ou performistas"11 (RANCIERE 2008, p. 20). E segue discorrendo que o poder do espectador é o de traduzir, cada um à sua maneira, aquilo que percebe traçando seu próprio caminho. Romano ao tratar do teatro físico, teceu algumas considerações a respeito da relação do corpo com a concepção da obra teatral e sua recepção pelo espectador que serão aqui apresentadas, pois entendemos que se aplica a nossa pesquisa. Ela expõe que:

O corpo é fundamental para a fusão das diversas camadas da obra, que resultam do emprego da riqueza expressiva da voz e do movimento, somada aos recursos técnicos do palco e da tecnologia visual. A síntese é formulada pelo espectador, guiado perceptualmente, e corporalmente, pelos atores em cena. (ROMANO, 2013, p. 221)

Romano (2013, p. 221) segue argumentando ainda que esse teatro “(...) encontra sua realização nesse corpo criativo situado no espaço da cena, organizando a teatralidade na relação com a corporeidade do espectador, gerando finalmente um conjunto orgânico".

Nesses dois trechos Romano defende que tanto o corpo do ator como do espectador são movidos no desenrolar do fenômeno teatral, um sendo guiado pelo outro de forma completa, em todas as suas dimensões psicofísicas. Nesse sentido (ROMANO 2013, p. 231) argumenta que “(...) a visualidade torna-se tridimensional e tátil, lembrando a vibração da pele que possibilita a operação corporal da audição".

Assim, partindo da concepção de que o público é também parte da obra artística, buscamos formas de potencializar a relação entre atores e espectadores, algumas vezes com envolvimento direto entre eles, outras vezes recorrendo a recursos como imagens e sons, de modo que ambas as partes se sintam em atividade todo o tempo. Acerca dessa relação, Bonfitto mencionando o trabalho de Brook explica que:

No instante que tem a duração de um milésimo de segundo, em que ator e público interagem, como em um abraço físico, é a densidade, a espessura, as múltiplas camadas, a riqueza - em outras palavras, é a qualidade do momento que conta. Sendo assim, cada momento pode ser frágil, desprovido de grande interesse ou, ao contrário, profundo em qualidade. (BONFITTO, 2013, p. 145)

11. "Los espectadores vem, sienten y comprenden algo em la medida em que componen su próprio poema, tal como lo hacen a su manera actores o dramaturgos, directores teatrales, bailarines o performistas." 
Em conclusão podemos dizer que a dramaturgia nesse processo será composta pelo ator em suas ações, falas, cantos, nas interações com os objetos e na relação com o público, ora apresentando seres fictícios, ora apresentando a si próprio, criando imagens e colocando seu corpo, seus desempenhos técnicos e artísticos em foco. Uma dramaturgia que emerge do suor, do contato com o outro, das dúvidas, das angústias, dos momentos de inspiração, dos erros, enfim, do corpo em movimento constante e dos diálogos permanentes que estabelece com o mundo que o envolve.

Por fim, concluindo nossa abordagem sobre a dramaturgia, apresentaremos outro conceito que foi levado em consideração para a elaboração das cenas: a estrutura rítmica jo ha kyu apresentado no Fushikaden por Zeami, 1966. O princípio significa abertura/começo-desenvolvimento/intervalo-final. Essa estrutura indica um começo suave, um aumento gradual de aceleração até chegar ao clímax. Após esse final rápido, acontece uma pausa para então reiniciar um novo ciclo jo ha kyu. Para a cultura japonesa a progressão apontada por esse princípio pode ser reconhecida tanto na natureza quanto nas expressões artísticas de todas as formas. Oida, ao tratar desse princípio, citando Zeami, explica que "todo fenômeno no universo se desenvolve através de uma certa progressão. Mesmo o canto de um pássaro ou o zunido de um inseto seguem esta progressão. Isso se chama jo ha kyu" (OIDA, 2014, p. 54). Pensando no ser humano, é um ciclo orgânico que pode ser observado nas transformações do corpo e em diversas atividades físicas. Um exemplo desse ciclo natural do corpo é a liberação de endorfina na prática de alguma atividade. Esse hormônio é liberado gradualmente até um pico, fazendo com que o cansaço diminua e o prazer cresça, aumentando o rendimento. Essa sensação de bem-estar dura muitas vezes até depois de terminada a atividade, caindo gradualmente de novo. Observamos essa estrutura rítmica também no sexo que vai aumentando a intensidade até uma explosão final.

No teatro $n o,{ }^{12}$ por exemplo, ele era aplicado ao programa das peças e tinha como objetivo suscitar o interesse do público ao longo das apresentações, culminando no final com uma peça de movimentos rápidos e vigorosos. Essa progressão, que era aplicada aos programas das peças de no, foi também aplicada à estrutura de uma composição. Além disso, toda cena do teatro no e cada fala de cada ator segue essa

12. Teatro nô é um gênero teatral tradicional japonês e um dos mais antigos que ainda sobrevive até aos dias atuais. 
estrutura rítmica. Acerca disso Giroux esclarece que "a abertura é o momento onde o ator procura estabelecer, em seu espírito, o tom a ser empregado; o desenvolvimento, aquele em que se disciplina a respiração antes de começar a cantar e o final, o momento da concretização pela emissão da voz" (GIROUX, 1991, p. 123). A partir dessa definição o jo ha kyu estaria permeando as nuances e graduações do trabalho do ator, desde seu primeiro impulso de preparação até o momento mais intenso.

O ritmo que permeia a peça também afeta o espectador que, como participante dessa criação, percebe em seu corpo essas variações. Seus movimentos internos, a tensão e o relaxamento são afetados pela forma que a estrutura é concebida. Portanto, o princípio jo ha kyu pode ser pensado também em relação a quem assiste que também sente essa crescente aceleração. Acerca disso, Oida explica que "uma vez que o jo ha kyu é um padrão fundamental que o público inconscientemente reconhece como verdadeiro, sua utilização ajuda a atuação a parecer mais orgânica e natural” (OIDA, 2014, p. 56-57). Dessa forma, a estrutura rítmica tem o poder não apenas de engajar os atores, dando a eles um impulso mais orgânico, como também o espectador que se envolve e se deixa afetar pelo crescimento gradual da intensidade em ciclos sequenciais.

A partir dessas ideias, procuramos estruturar a dramaturgia seguindo o princípio japonês jo ha kyu de modo que a progressão servisse de inspiração para a elaboração das cenas contaminando a estrutura do espetáculo como um todo. Dessa forma, assim como cada cena deveria ter um início mais suave, um desenvolvimento caminhando para uma intensidade maior e em seguida um desfecho, procuramos fazer com que o espetáculo, como um todo, também seguisse essas graduações. Ao longo dos demais capítulos, procuraremos deixar claro como este trabalho se deu. 


\section{Capítulo III - Capoeira}

\subsection{Seu surgimento}

Muitas teorias buscam explicar as origens da arte marcial "capoeira" e o termo que a designa, entretanto, muitas delas são de difícil comprovação pelo fato de existir pouca documentação a respeito.

Sobre o local de surgimento da "capoeira", discute-se se foi na África ou no Brasil. Todavia, é bastante aceito que sua origem tenha ocorrido em nosso país, pelos escravos como defesa pessoal e entretenimento. Uma das razões para essa crença é a de que pesquisadores e historiadores buscaram traços da "capoeira" na África, especialmente em Angola de onde veio a maior parte dos negros para trabalharem como escravos, mas nada encontraram, além de algumas semelhanças com algumas danças da região.

Quanto ao termo "capoeira" existe uma grande discussão a respeito, em que muitas teorias foram levantadas e podem ser apreciadas em nossa literatura. Pretendemos apresentar, sucintamente, algumas dessas teorias, não com o objetivo de esgotar o assunto, mas buscando traçar um panorama sobre a matéria, a fim de introduzir o assunto que desenvolveremos melhor ao longo deste trabalho.

Segundo Waldeloir Rego, 1968, foi encontrado registro do termo "capoeira" pela primeira vez em 1712 por Rafael Bluteau. Rego explica que outras conceituações sobre o termo foram apresentadas, inclusive pelo romancista José de Alencar em Iracema, mas todas foram criticadas, especialmente por Macedo Soares. Em 1979, Henrique de Beaurepaire Rohan divulgou na Revista Brasileira ${ }^{13}$ como "capoeira" origem do tupi co-puera, quer dizer roça velha. Na sequência Macedo Soares refutou este significado explicando que "capoeira" vem de caa-puera do tupi, e significa mato que cresceu no lugar do mato virgem derrubado. A polêmica entre os dois perdurou por muito tempo, enquanto paralelamente, novas acepções surgiam.

Rego, 1968, ainda a cerca do termo que designou a arte marcial afro-brasileira, explica que Antenor Nascentes apresenta outro significado para a origem do termo

13. Hemrique de Beaudepaire Rohan, Reforma da Ortografia Portuquesa, in Revista Brasileira, N. Midosi, Rio de Janeiro, 1979, Tomo II, p. 426. 
"capoeira" ligando sua origem à ave de mesmo nome, mas também denominada uru. Esta ave é pequena como a perdiz, habita as matas, sendo facilmente domesticada e seu canto é considerado singular como um assovio trêmulo e contínuo. Nascentes explica ainda que a ave macho é muito ciumenta e, em virtude disso, trava embates com os rivais invasores de seu território. Por essa razão estabeleceu-se a relação dessa ave com os homens que lutam recorrendo à destreza e agilidade.

Rego, 1968, ainda apresenta que o termo "capoeira" está ligado ao vocábulo português que significa "cesto para guardar capões" fundamentado em textos da época como o de Fernando Mendes Pinto e no dicionário escrito por Adolfo Coelho, ${ }^{14}$ em que a "capoeira" deriva de capão mais o sufixo "eira". Esse historiador explica ainda que, segundo Beaurepaire Rohan, a conexão do vocábulo português com o jogo de "capoeira" se dá também pela semelhança entre a briga de galos e a dinâmica dos dois indivíduos que se batem por divertimento.

Rego, 1968, também a respeito do étimo "capoeira", explica que Brasil Gerson defende que o jogo de "capoeira" surgiu no mercado de aves do Rio de Janeiro, em que os escravos brincavam pelas ruas, transportando galinhas nas "capoeira". Esse historiador segue explicando que Antenor Nascentes defendia o entendimento de que o termo que designa a coisa passou a designar também a pessoa ligada a ela, ou seja, deuse uma metonímia res pro persona. Ou seja, quem joga "capoeira" pode também ser chamado de "capoeira".

Quanto à trajetória da "capoeira", desde seu surgimento, é repleta de altos e baixos, a partir de sua origem primitiva pela prática dos escravos até o reconhecimento como patrimônio cultural brasileiro. $\mathrm{O}$ respeito e o reconhecimento que se tem dado à "capoeira" hoje destoam de vários momentos de sua história, quando os capoeiristas sofreram severa repressão policial e a prática da "capoeira" chegou a ser criminalizada. Muitos documentos apresentam a "capoeira" associada à vagabundagem e à lesão corporal, crimes tipificados pelo Código Penal de 1890. Nesse sentido, Thomas Holloway afirma que:

As muitas tentativas de reprimir os capoeiras dão uma ideia da persistência do fenômeno e sugerem a importância da capoeiragem

14. COELHO, Francisco Adolfo. Dicionário manual Etimológico da Língua Portuguesa/contendo a significação e prosódia, P. Plantier Ed., Lisboa, p. 204 
como contestação ao sistema de controle social dentro do submundo dos escravos e seus aliados nas camadas baixas da sociedade urbana. (HOLLOWAY, 1989, p. 130)

A saída da "capoeira" da marginalidade para ser estudada e apreciada inclusive nos meios acadêmicos é recente, começando pelo Governo de Getúlio Vargas quando a "capoeira" tomou o viés espetacular com a criação da "capoeira" Regional por Mestre Bimba.

Percebe-se, portanto, que muito já se pensou e se escreveu a cerca da origem da "capoeira", e muito será ainda levantado. Mas, em virtude de vários fatores, especialmente da falta de documentação conhecida da época, suscita ainda muitas discussões.

\subsection{O jogo: princípios e técnicas}

Antes de discorrer mais detalhadamente sobre o jogo na "capoeira", convém esclarecer que, para esta pesquisa, consideramos a "capoeira" como uma só, lançamos mão de movimentos e variações encontradas tanto na chamada "capoeira angola" como na “capoeira regional”. Corroborando essa prática, Rego considera que:

A "capoeira" é uma só, com ginga e determinado número de toques e golpes que servem de padrão a todos os capoeiristas, enriquecidos com criações novas e variações sutis sobre os elementos matrizes, mas que não os descaracterizam e interferem na sua integridade. (REGO, 1968, p. 33)

Rego continua explicando que a "capoeira" veio ao longo do tempo se transformando pela própria ação dos capoeiristas, que acrescentaram golpes ou reproduzem movimentos aprendidos de seus mestres, a partir também da interpretação pessoal, que dão uma característica pessoal às técnicas e aos toques. De todas as transformações, a mais conhecida foi de Mestre Bimba quando criou a "capoeira" Regional. Para esta "capoeira", Mestre Bimba, recorreu a golpes do batuque, do jiujitsu, do judo e a elementos da coreografia do maculelê, dentre outros, com o objetivo de tornar a "capoeira" mais forte como ataque e defesa pessoal. Até hoje a "capoeira" vem sofrendo transformações conforme explica Rego, 1968, a partir de uma enquete realizada com capoeiristas mais antigos, apontando que:

Quase todos eles possuem um ou mais golpes ou toques diferentes dos demais, inventados por eles próprios ou então herdados de seus mestres ou de outros "capoeiras" de suas ligações, isso sem falar na 
interpretação pessoal, embora sutil, que dão aos golpes e toques. (REGO, 1968, p. 33)

A partir do exposto, percebemos que a "capoeira" não é uma arte de pura reprodução de movimentos previamente determinados e fixados, mas que sofre transformações constantes a partir de matrizes que guiam o praticante durante a prática. Todas as mudanças históricas e sociais aparecem refletidas na prática desta luta-dança como se a memória de todo esse período ficasse impressa nos movimentos dos capoeiristas. Esta memória corporificada resultou nas "capoeiras" que existem hoje e nas técnicas que observamos nas rodas. Seguindo este pensamento, Rego ressalta que:

O capoeira tem liberdade para criar na hora golpes de ataque e de defesa conforme seja o caso, que nunca foram previstos e sem nome específico e que após o jogo ele próprio não se lembra mais do tipo de expediente que improvisou. (...) no jogo da "capoeira" vai muito de pessoal. (REGO, 1968, p. 34)

Entende-se, portanto, que a "capoeira" é uma arte marcial que vem se modificando ao longo dos anos, pelo contexto histórico e social e pela necessidade de quem pratica sem, todavia, perder suas bases e fundamentos.

Tendo em vista as diversidades encontradas na prática da "capoeira", não nos limitamos a pesquisar aspectos de apenas um "tipo" específico como as chamadas "capoeira angola" e "capoeira regional", mas recorremos a esta arte como um todo, a fim de fornecer material amplo e criativo para os atores. Levamos, portanto, em conta os elementos que permeiam o universo capoeirístico, de modo a ampliar as possibilidades da investigação prática.

Tratemos agora mais especificamente da prática da "capoeira", ou seja, do jogo e das técnicas que formam esta arte marcial.

\subsubsection{A Música}

A "capoeira" é uma arte marcial que tem como diferencial em relação a várias outras artes marciais o elemento musical. Por conseguinte, todos os movimentos são sempre realizados ao som de cantigas e de toques de instrumentos como berimbau, caxixi, agogô, atabaque, pandeiro e reco-reco. O berimbau é considerado o principal instrumento da "capoeira", são três tamanhos - o grande chamado de gunga com som mais grave, o médio e o viola com som mais agudo -, é seu posicionamento que define onde está a abertura da roda. Ao ser posicionada a bateria de instrumentos, se demarca 
um espaço circular concretizado pelo posicionamento dos participantes. A roda é formada por pessoas que seguem o toque cantando e, em alguns grupos, batendo palmas.

A conexão entre o jogo, que se realiza no centro da roda, os toques e cantos, é imprescindível, o que faz com que a "capoeira" se assemelhe a uma dança. Identificamos, portanto, uma indissociabilidade entre as manifestações sonoras e corporais em que o capoeirista se movimenta sempre em conexão com o que está sendo tocado e cantado.

$\mathrm{Na}$ roda de "capoeira" existe uma sequência de músicas executada com o objetivo de graduar a energia e ditar o ritmo do jogo. Esta sequência, embora siga padrões, sofre variações dependendo do grupo. Entretanto, para efeitos nesta pesquisa, procuramos fazer um panorama resumido dessas músicas, a fim de esclarecer que lugar cada uma delas ocupa em uma roda de "capoeira".

$\mathrm{Na}$ "capoeira angola", via de regra, abre-se a roda com a ladainha. Esta é uma cantiga que, como o próprio termo indica, remete à fala repetida e ritmada e à oração. Tem um andamento mais lento e sua letra é composta normalmente de fatos e lendas ocorridos no universo da "capoeira" e de figuras famosas desta arte. Enquanto a ladainha é cantada não se pode jogar; é um momento em que se busca a criação de uma atmosfera específica. Nesta passagem de um estado cotidiano para um estado criado pela coletividade presente, os corpos se transformam, o grupo se conecta com a ancestralidade, a concentração se dilata e os participantes se conectam criando unidade, um conjunto harmônico.

Na sequência vem o canto de entrada, também comum na "capoeira angola", é quando o jogo se instaura. Neste início os capoeiristas se posicionam próximo ao berimbau, usualmente se benzem, cumprimentam os instrumentos, se saúdam e então iniciam o jogo que normalmente é lento, pois é um momento de aquecimento e de estudo da movimentação do parceiro. Após o início do jogo, outra dupla se posiciona ao pé do berimbau para se preparar para entrar na roda.

Por sua vez, na "capoeira regional”, em vez de ladainha, toca-se a quadra, proposta por Mestre Bimba e formada por quatro versos simples, cujo conteúdo é bastante variado, podendo partir de histórias, mitos da "capoeira", personagens importantes, advertências, dentre outros temas.

Em seguida toca-se e canta-se o "corrido", presente tanto na "capoeira angola" como na "regional". O "corrido" tem um ritmo mais acelerado, ele é composto de 
perguntas e respostas curtas e ágeis. Acrescenta-se ainda o canto e o ritmo interferem no jogo, assim, como o jogo pode afetar o canto. O mestre que puxa o "corrido" pode, por exemplo, repreender uma atitude antiética de um capoeirista, estimular um jogo que não está sendo jogado a contento, finalizar um jogo para recomeçar outro, etc.

Por fim, finaliza-se a roda com um canto específico como "Vou-me embora". É importante que o encerramento seja bem marcado e com um grau de energia alto para que a roda termine no auge. Estabelecendo um paralelo com o que expusemos sobre o jo ha kyu, vemos aqui um exemplo claro desse princípio japonês que aponta para essa progressão rítmica, indo de lenta e solene com a ladainha para rápida e vigorosa com os corridos e o canto de despedida.

As variações de música durante uma roda influem na composição da atmosfera e impulsionam o capoeirista, influenciando seus movimentos e conduzindo-o a um estado de ânimo específico. Quem presencia uma roda de "capoeira", ainda que não jogue, percebe que o ritmo e o canto têm um efeito contagiante, estimulando sensorialmente todos os presentes. Quem pratica essa arte marcial com mais frequência percebe essa afetação com maior intensidade.

Em entrevista pessoal, quando perguntado sobre a relação entre as afetações sensoriais e emocionais e as músicas de "capoeira", prof. Gugu Quilombola explica:

\begin{abstract}
A música conduz o jogo, ela dita o jogo. Aí você entende as movimentações. (...) Então, se está mais pesado, um jogo pensado mais pra luta, não vai fazer um $\mathrm{Au}$ aberto, todo floreado porque não cabe no jogo, vai tomar uma cabeçada, alguma coisa assim. E a questão rítmica é muito importante na "capoeira". Fala que o ritmo é nosso primitivo né? É o coração. Então isso influencia totalmente no jogo. No jogo de "capoeira" a música é importantíssima. Aí a gente consegue criar aquela atmosfera, aquela energia na roda. E aí acontece que você executa movimentos que nunca treinou, por causa dessa adrenalina que a gente constrói, dessa emoção que tem dentro da roda de "capoeira". Essa energia que a gente consegue construir com a musicalidade é muito forte. ${ }^{15}$
\end{abstract}

A relação do corpo com a música, aqui exposta, nos remete a interação entre o corpo e o mundo apresentada anteriormente. Quando um capoeirista entra em contato

15. Depoimento dado pelo Prof. Gugu Quilombola em 06 de março de 2015, na sede do Grupo Quilombolas de Luz Capoeira- Bela Vista 
com a música por meio de seus sentidos, deixa ecoar essas vibrações em todo seu corpo, se afeta e age a partir do que está ouvindo, ele está presentificando o fenômeno explicado por Merleau-Ponty do "ser no mundo". A afetação da música sobre o estado emocional do ser humano é bastante conhecida e há muito tempo estudada. Desde que estamos no ventre materno, o som tem forte influência sobre o ser humano, nos afetando no dia a dia, desde o barulho do trânsito que aumenta nosso nível de estresse até uma música clássica que nos traz tranquilidade. Assim, quando pensamos na "capoeira" não podemos deixar de levar em consideração a influência que as músicas tocadas e cantadas exercem sobre os participantes.

Em razão da forte influência do som sobre o comportamento humano, selecionamos este como um dos pontos a ser investigado com os atores na prática, ou seja, buscamos descobrir de que forma a criação dos atores pode ser influenciada pelas músicas executadas nas rodas de "capoeira" e pelas que foram compostas a partir desse universo como diversas músicas do repertório popular brasileiro.

Outro aspecto que faz parte do universo musical e que é importante considerar para esta pesquisa é a conexão entre o processo de criação das músicas, a Estética e o Contexto Cultural onde foi concebida. Fillat afirma que:

A memória sonora gera durante nossas vidas uma infinidade de relações com nossa psique, estabelecidas à base de rastros ou impactos emocionais que, ao longo de nossa existência, vão criando um arquivo de sons. Este arquivo é formado por experiências próprias e códigos culturais herdados. (FILLAT, 2011, p. 29)

No caso da "capoeira", uma arte afro-brasileira, este arquivo composto de cantos e toques executados nas rodas são resultantes da herança africana mesclada com a realidade brasileira desde a época da chegada dos escravos até os dias de hoje. Considerando a conexão da música com as experiências que se deram ao longo da existência dos seres humanos, compreende-se a razão pela qual as músicas utilizadas na "capoeira" têm grande importância em sua prática e porque foram se alterando ao longo de sua história, sendo afetadas pelo entorno e se transformando até os dias atuais.

Pensando nessa herança cultural, convém, portanto, tratar, ainda que brevemente, da música na cultura africana. Fillat, 2011, explica que sua história é tão variada quanto às etnias existentes. Entretanto, algumas semelhanças se estabelecem entre todas elas, uma vez que a música africana acompanha diversos acontecimentos de seus povos, desde os mais importantes até os mais cotidianos. Isso porque o africano crê 
que tudo que existe está ligado e comunga como uma corrente de forças. Filosofia, música, dança, teologia, sociologia, nascimento e morte constituem uma estrutura que, ao ser retirado uma única parte, todo o resto desmorona. Esta cosmovisão africana trata das inter-relações entre todos os elementos da natureza e entre o mundo físico e o metafísico, contrapondo-se à dualidade que predomina no mundo ocidental. Dentro desta cosmovisão, o corpo tem uma participação fundamental na conexão entre todos os elementos, pois é o local por excelência de relações interiores e exteriores. Entendendo isto percebemos por que a "capoeira", como arte brasileira criada pelos africanos no Brasil e por seus descentes, é uma arte marcial que traz em seus fundamentos a música e a dança de modo tão marcante.

Quando os africanos chegaram ao Brasil trouxeram com eles todo este repertório cultural resultado de anos de história. Todavia, a realidade aqui era diferente da que viviam na África, e, portanto, esta nova realidade passou a fazer parte da vida desses escravos e a integrar o repertório cultural deste grupo. Na medida em que viviam no então Brasil escravocrata, descendentes brasileiros foram nascendo, a sociedade foi seguindo seu curso e, assim, dessa mescla, uma nova cultura foi surgindo. Conforme já foi dito, as músicas que foram e são cantadas hoje em dia surgiram destes contextos sociais. Por exemplo, o toque da Cavalaria servia para alertar os capoeiristas da chegada dos agentes policiais que na época os perseguiam. Hoje, este toque perdeu sua utilidade, embora alguns mestres ainda saibam executá-lo. Um exemplo de música que perdura até hoje é Lapinha do Mestre Jogo de Dentro que foi inspirada na biografia do capoeirista Besouro Mangangá ou Besouro Cordão de Ouro, famoso tanto por suas composições como por seus enfrentamentos com a polícia e contra os abusos dos senhores de engenho. Esta música serviu posteriormente como inspiração para Baden Powell compor a canção Lapinha que ganhou o 1. ${ }^{\circ}$ lugar na I Bienal do Samba.

Analisando tudo o que foi exposto sobre os aspectos musicais da "capoeira" e sobre a própria dinâmica desta arte, identificamos um elemento que perpassa todo esse processo que é o movimento. Isto porque quando falamos de música, não nos referimos apenas a um sentido isolado, o da audição, mas a todo o sistema sensorial, uma vez que a música afeta o corpo humano como um todo. Por essa razão, quando tratamos da música, devemos considerar também o movimento, já que ele acontece, ainda que minimamente, independentemente de estar inserida em um contexto específico de dança. A partir dessa noção, é importante pontuar que quando falamos em movimento na música, um dos conceitos que aparece comumente é o de gesto musical que, via de 
regra, nos conduz a definições de gestos físicos. Meelberg argumenta de forma clara a importância de compreender a relação entre movimento e música quando expõe que:

Gesto musical tem sido considerado um importante conceito na pesquisa da música contemporânea. Música é criada por movimentos humanos, música consiste de movimentos sônicos, e os ouvintes são tanto metaforicamente quando literalmente movidos pela música. Consequentemente, movimento e gesto são vitais para entender o que é a música, como ela é produzida e o que ela pode fazer. ${ }^{16}$ (MEELBERG, 2011, p. 127)

Zbikowski, 2011, também discorre a respeito da relação entre sons e movimentos explicando que como o gesto musical reflete um mapeamento conceitual no qual o conhecimento de uma área de experiência, a saber, gestos físicos, é utilizado para dar estrutura a outra área de experiência, sequência de materiais musicais, entendese, portanto, que para compreender música faz-se necessário lançar mão dos aspectos físicos para compreender os musicais. Esta relação se dá pelo fato de que, quando pretendemos estruturar uma experiência musical, todo o aparato físico é mobilizado, uma vez que é por meio dele, ou seja, de todos seus recursos sensoriais, que criamos e percebemos a música. Acerca dessa conexão Kuhl expõe que:

O gesto musical é um fenômeno cognitivo, emergindo na mente em resposta a um primeiro estímulo musical. Quando ouvimos uma música, o que na verdade ouvimos é um fluido auditivo, que está sendo processado, por conseguinte, pela nossa percepção auditiva. Para processar de maneira econômica e efetiva o fluído sônico da informação, nosso aparato cognitivo necessita organizar o estímulo em "pedaços" de certos tamanhos. Estes pedaços são representados de maneira amorfa na mente como gestaltes, e descritos de maneira variável como "formas em movimento" (Hanslick), "afetos de vitalidade" (Stern) e "formas energéticas' (Hatten). O gesto musical se origina a partir de um nível genérico de percepção, onde é relacionado à percepção gestáltica, ao movimento motor e a imagens mentais. Gestos, por conseguinte, são gestantes ricas que combinam informação auditiva (ouvir o movimento) com informação visual implícita (imaginar o movimento), informação somato-sensória (sentir o movimento) e informação emocional (interpretar o movimento). Em um nível mais alto de cognição, gestos são organizados em

16. "Musical gesture has become an important concept in contemporary music research. Music is created by human movements, music consists of sonic movements, and listeners are both metaphorically and literally moved by music. Consequently, movement and gesture are vital in trying to understand what music is, how it is produced, and what it can do." 
grupos e sequências que levam à forma e à narrativa musical. ${ }^{17}$ (KUHL, 2011, p. 2)

Entendemos, portanto, que para compreendermos a música faz-se necessário entender como nosso corpo processa as informações musicais a fim de torná-las acessíveis a nossa cognição. Desta forma, é fácil estabelecer a relação entre gesto musical e gesto físico, uma vez que ambos estão conectados a uma mesma estrutura, o corpo humano. Sendo este corpo e seus movimentos resultante de tudo o que o cerca, a música, como expressão humana, também sofre este processo. Desenvolvendo este assunto, Snyder explica que:

Recente teoria tem sugerido que os mapeamentos metafóricos não são arbitrários, mas são baseados em estruturas cognitivas corporais fundamentais generalizadas de experiências físicas recorrentes, especialmente de experiências de nossos próprios corpos. Estas estruturas cognitivas têm sido chamadas de "esquemas de imagem". (...) Esquemas de imagem representam as mais estáveis constâncias e estruturas que nós seres humanos compartilhamos, derivados de padrões dinâmicos de interação com nosso meio ambiente. ${ }^{18}$ (SNYDER, 2000, p. 108)

Esse esquema de imagem pode ter como função original conectar sequências motoras a fim de construir uma imagem coerente para o mundo físico. Esta construção não se dá apenas pelo sentido visual, mas por todo o aparato sensório motor, tendo, portanto, um componente kinestético. Dessa forma, quando precisamos explicar uma

17. "The musical gesture is a cognitive phenomenon, emerging in the mind in response to musical priming. When we listen to music, what we actually hear is an auditory stream, which is subsequently being processed by auditory perception. In order to economically and effectually process the sonic stream of information, our cognitive apparatus stands in need of organizing input in "chunks" of a certain size. These chunks are represented amodally in the mind as gestalts, and variously described as "moving forms' (Hanslick), 'vitality affects' (Stern) and 'energetic shaping' (Hatten). Musical gesture stems from the generic level of perception, where it is tied to gestalt perception, motor movement and mental imagery. Gestures, accordingly, are rich gestalts, that combine auditory information (hearing the movement) with implied visual information (imagining the movement), somatosensory information (feeling the movement), and emotional information (interpreting the movement). At a higher level of cognition, gestures are organized in groups and sequences, leading to musical form and narrative (...)"

18. "Recent theory has suggested that metaphorical mappings are not arbitrary, but are grounded in fundamental embodied cognitive structures generalized from recurring physical experiences, especially the experience of our own bodies. These cognitive structures have been referred to as 'image schemas.' (...)Image schemas represent the most stable constancies and structures we all share as human beings, derived from dynamic patterns of interaction with our environment". 
ideia ou compreendê-la, lançamos mão de todo nosso corpo e de todas as informações registradas nele por nossas vivências, por tudo que experenciamos. Organizamos nossas compreensões a partir do que conhecemos e vivemos. Entende-se assim, que "esquema de imagem" serve de ponte entre a conceituação e a experiência (SNYDER, 2000). ${ }^{19}$ É possível, dessa forma, fazer uma conexão da noção aqui abordada com o defendido por Alva Noe, 2010, já que de acordo com este filósofo somos fruto das relações que estabelecemos com o nosso entorno, e que o corpo, ao mesmo tempo em que dá estrutura para estas relações, vai sendo moldado por elas. Estabelecendo conexão do exposto acerca da música, Snyder, 2000, conclui que:

Sendo a música uma manifestação humana e, portanto, decorrente do ambiente e do contexto cultural que a circunda, ela segue o mesmo processo do "esquema de imagem" exposto. O "esquema de imagem" tem como função compreender ideias abstratas e um dos aspectos do significado da música é certamente a projeção de ideias abstratas (...) Compreender uma possível conexão metafórica entre música e experiência pode nos ajudar não apenas a compreender música, mas também a criá-la. ${ }^{20}$ (SNYDER, 2000, p. 110)

Temos, por conseguinte, que, se toda música está intrinsecamente conectada a um contexto cultural específico, que promove determinadas experiências, e ao conceito de gesto e de movimento físico, ao discorrermos sobre a "capoeira”, não é possível considerar separadamente a história que a fundamenta, os movimentos realizados hoje pelos capoeiristas e as cantigas e toques que integram seu repertório, uma vez que,

19. "The actual cognitive form that image schemas are thought to take is somewhere between concrete, specific visual images and abstract concepts. That is, image schemas are often derived from types of situations that we can visually imagine, but that are more abstract than any particular image. Our understanding of an image schema such as "up" and "down," for example, is not purely linguistic and involves mental imagery of some sort, although it is not necessarily imagery of specific things. This is why it may often be difficult to explain the meaning of image schemas using only words. (Try to imagine explaining the meaning of up and down without using some sort of visual images or physical gestures referring to our own bodies.) Although image schemas are not so abstract that we cannot form any kind of image in relation to them, the image we do form may have components that are not strictly visual.4 This is another way in which image schemas are different from either visual images or abstract concepts- they can have a kinesthetic component and represent muscular sensations in relation to particular experiences; they can have a particular physical "feel" to them." (SNYDER, 2000, p. 108)

20. "We have seen that image schemas come into play in understanding abstract ideas, and one aspect of the meaning of music is certainly the projection of abstract ideas. (...)Understanding possible metaphorical connections between music and experience can help us not only understand music, but also create it”. (SNYDER, 2000, p. 110-111) 
apesar de estarmos tratando de elementos que poderiam ser considerados isoladamente, são na verdade manifestações que coexistem, dando forma a uma única manifestação artística.

Pensando na relação da prática da "capoeira" com o contexto que a cerca, entendemos porque tantas transformações têm ocorrido em relação a sua parte musical. Ao estudar as músicas, percebe-se que muitas que eram executadas no passado, não fazem mais parte do repertório de muitos grupos, enquanto outras surgiram como reflexo das experiências vividas. Entretanto, a essência musical dessa arte permanece próxima de sua origem, mantendo ainda inserida nela a memória de tempos passados. Assim, as ideias abstratas, de todo o histórico que envolve essa arte, aparecem fisicalizadas e concretizadas na intensidade dos toques, nas variações de ritmo, nas oscilações entre tensão e relaxamento, nas letras das cantigas, nas repetições de frases dando a característica cíclica para as músicas, na contundência ou suavidade dos sons produzidos pelos instrumentos e no fluxo dos movimentos. Todos os aspectos históricoculturais aqui levantados são claramente percebidos nos movimentos dos praticantes durante o jogo em que são afetados por todo o contexto.

A respeito de todas essas conexões que se estabelecem durante uma roda de “capoeira”, o prof. Gugu Quilombola explica:

O corpo, o movimento e a capoeira são uma coisa só (...) O jogo tem que ser de acordo com o ritmo, harmonia, a cadência. Alguns mestres quiseram colocar que num toque você faz isso e no outro você faz aquilo. Mas não tem muito disso de fato. Tem a intenção do jogo que muda. E essa intenção também muda de acordo com o cântico. Então, não é que é proibida uma coisa num jogo e permitida no outro. Tem que jogar de acordo com o ritmo. Então essa questão do ritmo e do cântico faz com que algumas coisas não caibam, que seja difícil você encaixar. A regra é a percepção. É difícil falar em regra nesses casos porque o meu biotipo é diferente do de outra pessoa. Não tem como falar pra pessoa fazer o mesmo que eu faço e vice-versa. Por isso que não tem tanta regra na capoeira. Tem a percepção. ${ }^{21}$

Fica, portanto, claro nesta explicação que a pessoalidade na execução dos movimentos, a relação do movimento com o toque e a percepção do conjunto, são as chaves para se improvisar de forma eficiente na roda. Por consequência, estas chaves

21. Depoimento dado pelo Prof. Gugu Quilombola em 06 de março de 2015, na sede do Grupo Quilombolas de Luz Capoeira- Bela Vista. 
foram utilizadas como referências para a criação de procedimentos visando o aprofundamento do trabalho com os atores.

Assim, por todo o exposto, compreende-se que a "capoeira" é formada por uma complexa estrutura que traz em sua formação aspectos técnicos, sonoros, sensoriais, ancestrais, da memória, somados ainda a subjetividade do praticante que capta com seu corpo toda essa dimensão e a torna visível e concreta no jogo. Identificamos, portanto, elementos objetivos e subjetivos operando conjunta e harmonicamente e dando forma a esta arte marcial.

\subsubsection{Andamento da Roda e as técnicas}

Com a instalação da roda e o início dos corridos, os participantes começam a jogar. Entre um jogo e outro acontece a "volta ao mundo", um recurso muito comum nas rodas, caracterizado pela caminhada dos jogadores por dentro do círculo e que é executado em algumas ocasiões específicas como quando uma cantiga termina e está prestes a iniciar outra, quando o jogo começa a ficar desnivelado e o jogador deseja quebrar a pressão sobre ele, quando um dos jogadores se machuca durante o jogo e precisa de uma pausa, dentre outras situações.

Outra regra a ser seguida pelos capoeiristas é a "compra do jogo". Quando um participante não deseja entrar com um novo parceiro, mas pretende jogar com alguém que já está no centro da roda, ele deve comprar o jogo com esta pessoa virando-se de frente para ela e dando as costas para o outro jogador, sempre protegendo o rosto e observando qual o melhor momento para esta entrada. É importante que durante a compra não seja quebrado o andamento do jogo e que o ritmo permaneça mesmo durante a troca de parceiros.

Outro elemento importante do jogo é a conexão entre os parceiros. A "leitura" do movimento do outro jogador é importante para que ambos consigam agir com presteza e criar um efetivo diálogo corporal, termo este utilizado tanto nos treinos de "capoeira" como na literatura especializada. Chamamos de diálogo a relação de "ação" e "reação", "pergunta" e "resposta" corporais que as técnicas de "capoeira" possibilitam. Assim, temos que, se o capoeirista recebe um ataque com a perna, como a "benção", e percebe com rapidez a intenção do parceiro, pode com mais eficiência se esquivar ou preparar um contra-ataque. Segundo Silva, 2008, a "capoeira" é primordialmente uma arte de não-contato, uma vez que se busca neste "diálogo 
corporal", uma sintonia entre o ataque e a esquiva de modo que os capoeiristas não se trombem e que, ao contrário, consigam se movimentar como se um estivesse respondendo ao que o outro perguntou. É nesta conexão que vemos alguns elementos da dança e a plasticidade dos movimentos serem realçadas. Assim, o capoeirista, ao receber um golpe, deve ser ágil o suficiente para sair da linha deste ataque, abrindo espaço para o movimento do parceiro se completar ao invés de ser interrompido pelo embate corporal. Esta dinâmica, entretanto, não implica na ausência de contato físico, pois são vários os movimentos que podem levar os jogadores a se tocarem como a baiana, a vingativa, o arrastão e a rasteira. O que será feito durante o jogo depende das estratégias e das táticas adotadas por cada capoeirista.

Continuando a metáfora do diálogo para o jogo de "capoeira", é importante ressaltar outro elemento, a improvisação. Assim como em um diálogo espontâneo entre duas pessoas, no jogo de "capoeira" também não se sabe o que será "falado" de antemão. Dessa forma, a adaptação ao que acontece no momento da ação é de extrema importância. É a partir deste caráter de improviso que o diálogo e a relação entre os dois parceiros vão sendo criados. Temos, portanto, que a atenção e a prontidão, que pode ser definida como o estado de preparação instantes antes da realização do movimento em si, devem estar definitivamente presentes durante esta dinâmica. $\mathrm{O}$ fato de existir algumas sequências previamente estabelecidas como as do Mestre Bimba e outras combinações entre as técnicas, não desconfigura a presença constante da improvisação no momento do jogo.

Os aspectos aqui abordados tiveram importância fundamental na pesquisa prática, pois foram utilizados como referências para a criação de procedimentos para os atores, visando a intensificação do diálogo corporal, o aprimoramento da relação com o parceiro, a criatividade, a adaptação à situação presente e a expressividade corporal. Mais adiante, descrevemos o processo prático e abordamos estes tópicos com mais atenção.

Seguindo com a investigação sobre a prática da "capoeira", outro aspecto foi aqui considerado: o treinamento. Quando tratamos da improvisação, da prontidão, do diálogo e de tantos outros elementos que demonstram a experiência do capoeirista, não se pode deixar de considerar que existe previamente um treinamento que começa com um trabalho individual de aprendizado das técnicas e de preparação do corpo no que diz respeito à resistência, à flexibilidade, à atenção e à coordenação motora, para que, gradualmente o praticante possa ir se ajustando às necessidades dessa arte marcial. 
Assim, as técnicas são ensinadas, das mais simples até as mais complexas, por um mestre ou por um praticante mais graduado que orienta a prática do aluno iniciante até que ele vá conquistando independência e liberdade criativa com base no que foi aprendido. Silva, 2008, explica que, enquanto professor, nunca deixa de dizer aos estudantes que cada um é um, reafirmando que as descobertas são sempre personalíssimas. Silva segue defendendo que "o que se busca nessa etapa é um contato íntimo com o próprio corpo através do universo da capoeira" (SILVA, 2008, p. 11). Esse momento inicial de autoconhecimento é importante, pois é desse modo que o praticante superará suas limitações e desenvolverá suas potencialidades, descobrindo, aos poucos, sua própria forma de jogar "capoeira". A pessoalidade presente na prática da "capoeira" apontada por vários mestres começa a ser desenvolvida desde o início do processo, quando o praticante dá seus primeiros passos na arte.

Pelo exposto percebe-se, portanto que, quando falamos em treinamento na "capoeira", não estamos falando de uma repetição mecânica de movimentos nem de um conjunto de técnicas pré-definidas e imutáveis. O treinamento de um capoeirista dura sua vida toda enquanto praticante. É por meio dele que ele aprofundará suas habilidades. E este aprofundamento de habilidades não é meramente uma reprodução fiel e virtuosa de algumas técnicas, mas também um estado de liberdade e de criação a partir das técnicas aprendidas. Portanto, quando vemos um capoeirista graduado jogando, percebemos que ele se expressa de maneira que suas características pessoais contaminam seu jogo bem como sua maneira de realizar os movimentos. Esta busca de pessoalidade, autoconhecimento e criação no treinamento foram importantes durante todo o trabalho com os atores na prática em sala de ensaio.

Ainda em relação ao treinamento, quando pensamos em seu início, pensamos na base, que no caso da "capoeira" é a ginga. Toda pessoa que inicia a prática da "capoeira", deve primeiramente aprender a ginga que é um deslocamento realizado com os joelhos semiflexionados, colocando-se um pé a frente do outro e afastados, mantendo o corpo relaxado para que o balanço do corpo possa ser fluido. Os braços devem estar posicionados em oposição às pernas, a semelhança do movimento natural de caminhar, e devem acompanhar o fluxo do corpo como um todo. É importante destacar que a função dos braços, além de ajudar no balanço, é a de proteger a parte superior do corpo, especialmente o rosto. É por meio da ginga que o capoeirista se relaciona com o espaço e com o parceiro, podendo ir para todas as direções e dando o dinamismo necessário para o jogo. $\mathrm{O}$ molejo, a flexibilidade, a prontidão e a agilidade da ginga possibilitam 
uma movimentação criativa e dinâmica; e foram utilizados como elementos para se pensar o trabalho do ator nesta pesquisa. Para isto tomamos emprestado o termo cinesfera que pode ser explicado como os "limites naturais do espaço pessoal" (LABAN, 1978, p. 69). ${ }^{22}$ Cinesfera ou kinesfera é "a esfera dentro da qual acontece o movimento" (RENGEL, 2005, p. 32). O corpo tem em torno de si um espaço delimitado por suas extremidades quando estendidas para longe do centro que, neste caso, é o centro do corpo do agente. Estando o corpo em movimento ou parado esta cinesfera existe. Quando o agente se move, esta esfera se move também, acompanhando o deslocamento do corpo. Assim, durante a ginga, a exploração desse espaço pessoal é intensa, uma vez que a movimentação é constante e multidirecional, ou seja, não tem como foco uma única direção. A expansão da cinesfera é variável, pois depende da forma como o corpo interage com o espaço. A extensão da cinesfera permite ao agente interagir com o espaço e com outras cinesferas. Temos ainda que, de acordo com Laban, 1978, a cinesfera pode se expandir ou se encolher de acordo com a amplitude ou contenção dos movimentos. Pensando no jogo de "capoeira", percebemos esses limites da cinesfera irem se desenhando na movimentação do capoeirista impulsionada pela ginga. É na delimitação desse espaço pessoal de cada jogador, na relação entre a expansão e o encolhimento das cinesferas de cada um e na conexão com o espaço circular definido, que nasce esse espaço de criação, de descontração e de ludicidade, onde os capoeiristas podem interagir e se expressar. Estas qualidades aqui expostas identificadas na ginga, foram aplicadas no trabalho prático com os atores visando a potencialização da exploração do espaço e da interação entre os parceiros de modo que eles encontrassem nessas relações possibilidades expressivas diversas.

No treino de "capoeira", partindo da ginga como forma de desenvolver a interação com o espaço e com o parceiro, vão sendo ensinadas as demais técnicas que muitas vezes podem variar de mestre para mestre e de grupo para grupo. Não se pretende aqui descrever minuciosamente todas as técnicas, pois com este trabalho não se objetiva organizar um manual de "capoeira". Em outras literaturas estas informações podem ser obtidas com maior detalhamento. O que se faz neste trabalho é apontar, de

22. "O alcance normal de nossos membros quando se esticam ao máximo para longe de nosso corpo, sem que se altere a posição, determina os limites naturais do espaço pessoal ou cinesfera, no seio do qual nos movimentamos. Esta cinesfera se mantem constante em relação ao corpo, mesmo quando nos movemos para longe da posição original, viajando com o corpo no espaço.” (LABAN, 1978, p. 69) 
forma sucinta, as principais técnicas, especialmente as utilizadas no treinamento dos atores, e os princípios que os estão embasando.

Basicamente a "capoeira" é composta assim: a) da ginga; b) de golpes de linha, como a benção e a chapa; c) de golpes giratórios, como a meia lua de frente e de compasso, a armada e a queixada; c) de posições invertidas, como a parada de mão ou bananeira, o Au e a parada de cabeça; d) de movimentos baixos, próximos do chão, como a negativa, a cocorinha e a rasteira; e) de saltos, como o mortal e o macaquinho; f) de movimentos com os braços, como o galopante e o telefone e g) de movimentos que pressupõem um contato físico maior, como a vingativa, a baiana e o arrastão, além dos golpes de cintura desprezada. As técnicas têm variação de nível, indo do baixo, próximo ao chão, ao alto, utilizando-se um, dois, três ou quatro apoios como, a título de ilustração: nos chutes (um); na parada de mão (dois); na cocorinha (três); na ponte (quatro); e no rolê (quatro).

Imagem 1: cocorinha

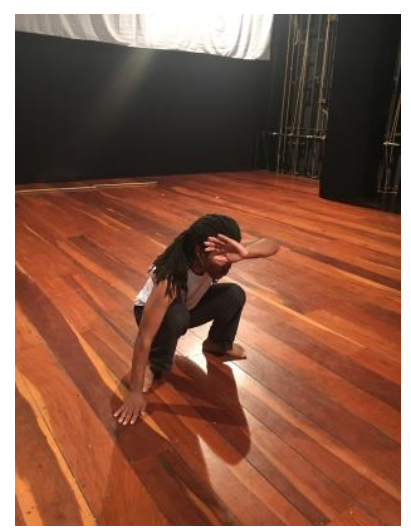

Fontes: arquivo do autor.

Imagem 3: au

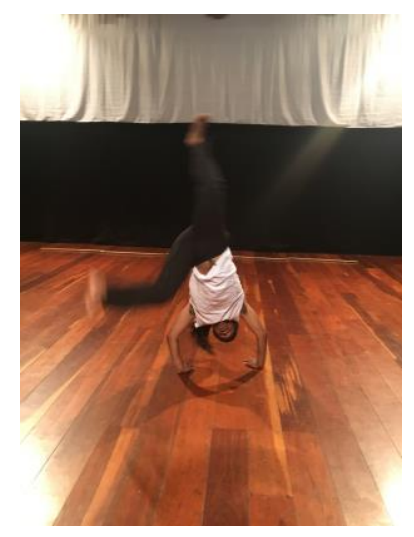

Fontes: arquivo do autor.

\section{Imagem 2: negativa}

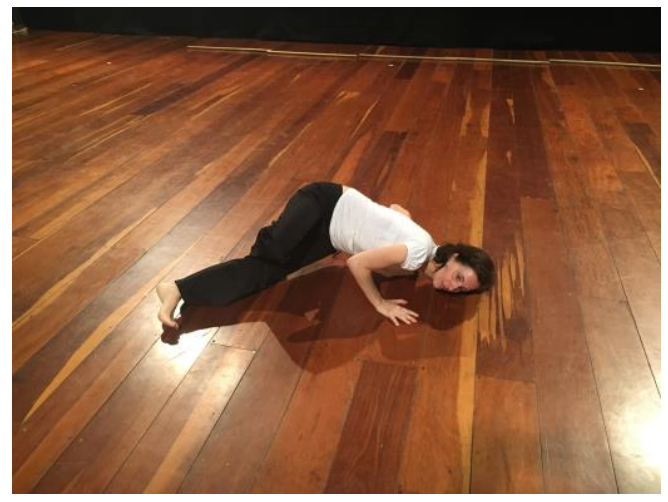

Imagem 4: queda de rim

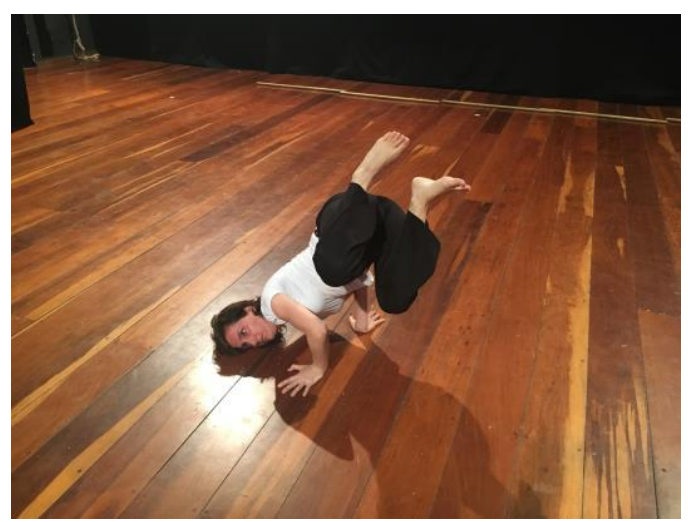


Imagem 5: base de ginga

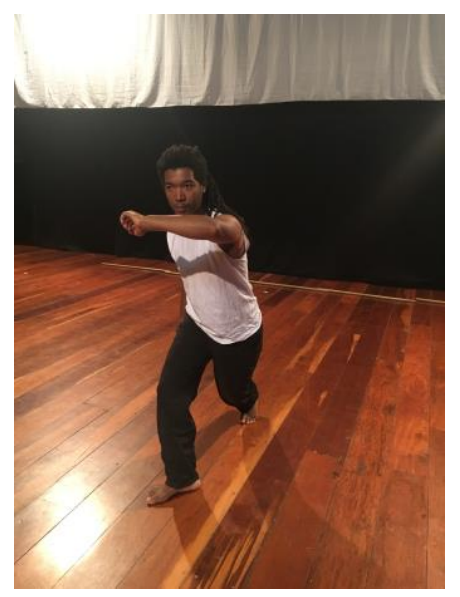

Fontes: arquivo do autor.

Imagens 7: preparação meia lua

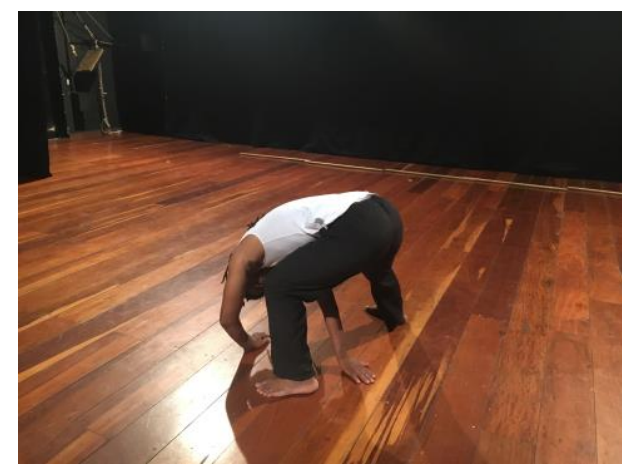

Fontes: arquivo do autor.

Imagem 9: preparação armada
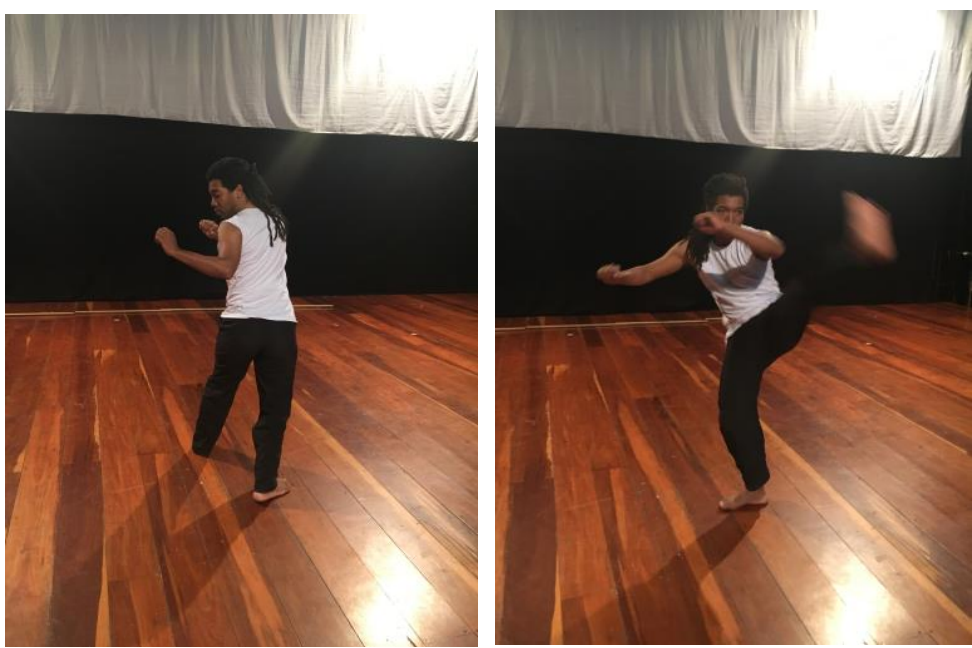

Fontes: arquivo do autor.
Imagem 6: rasteira

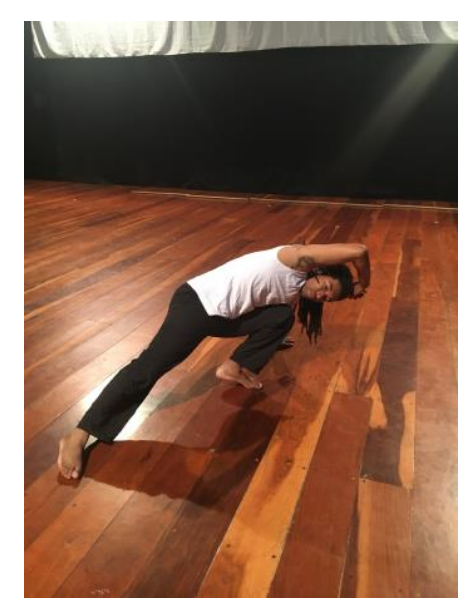

Imagem 8: meia lua de compasso

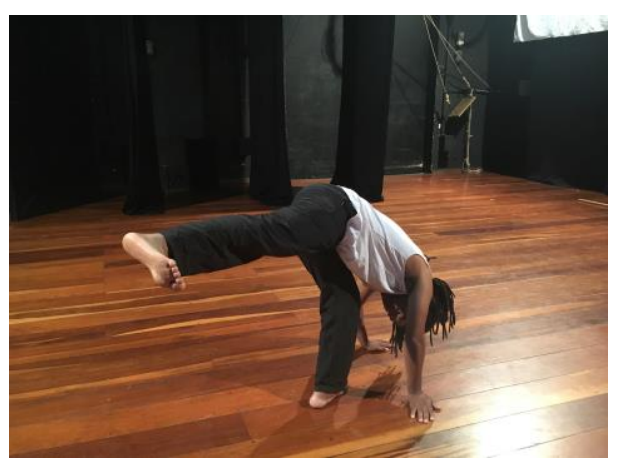

Imagem 10: armada 

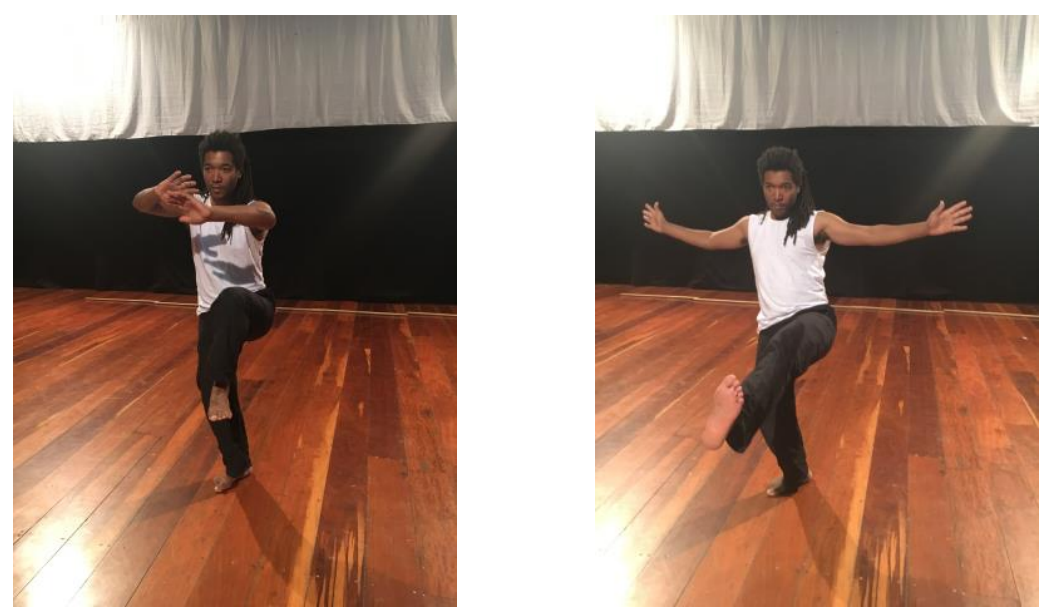

Fontes: arquivo do autor.

Imagem 13: vingativa

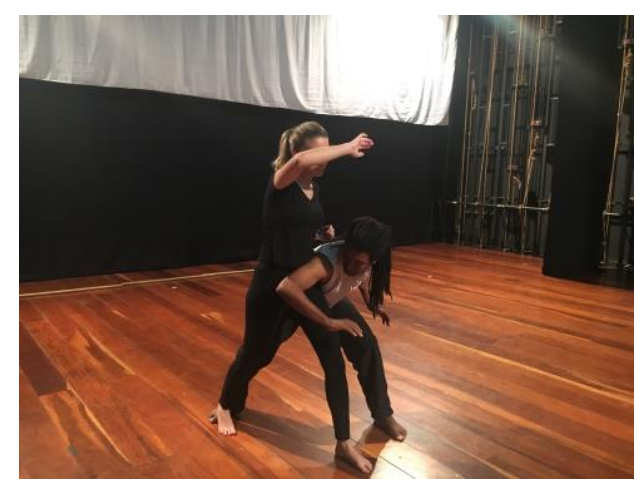

Fontes: arquivo do autor.
Imagem 14: telefone

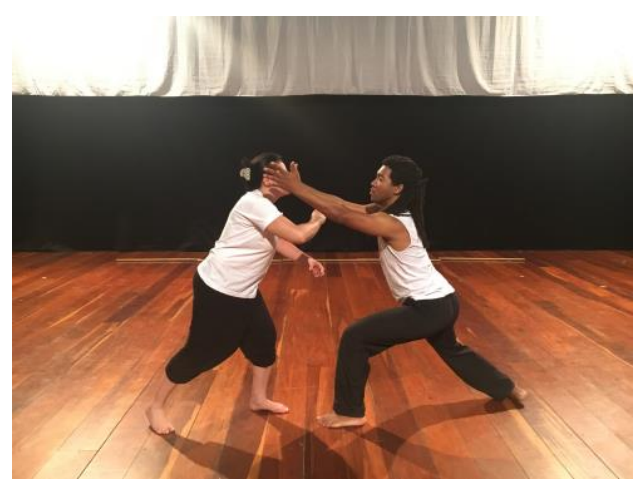

Imagem 15: baiana

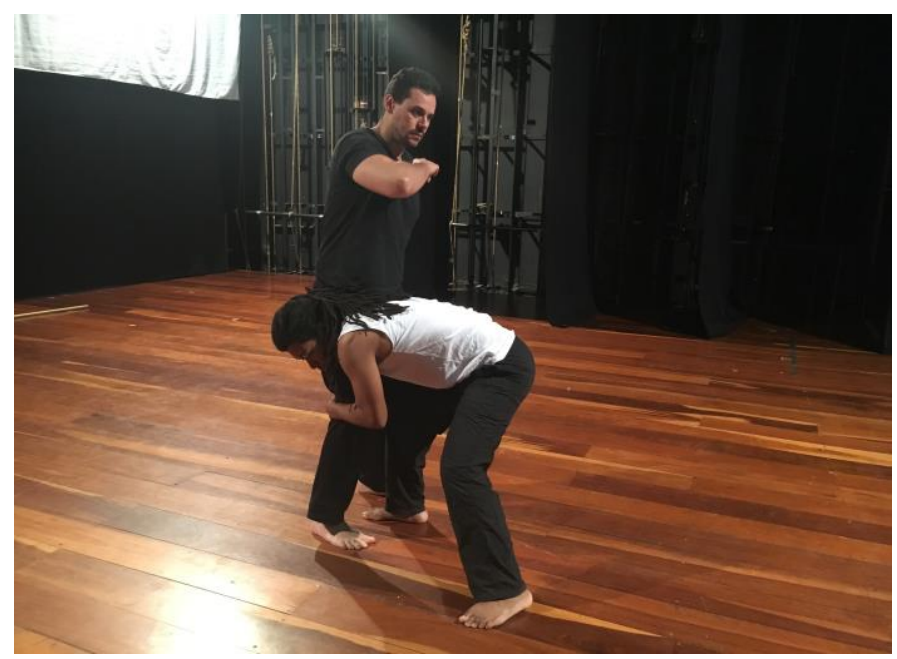

Fonte: arquivo do autor. 
A partir das técnicas e das movimentações presentes na "capoeira", alguns princípios podem ser identificados conforme expostos a seguir:

1) Espiralidade: a circularidade e a espiralidade estão presentes em muitas técnicas desde as mais simples como a cocorinha até uma mais complexa como a armada. No caso da armada o corpo se torce por inteiro criando uma espiral, para que, auxiliada pelo impulso do quadril, a perna possa sair com a altura e a potência necessárias. O quadril, portanto, é um componente fundamental na "capoeira", pois, estando localizado no centro do corpo, dá o equilíbrio e o impulso necessários para a realização da espiralidade.

2) Relaxamento ativo: o relaxamento ativo, tão importante na maior parte das artes marciais, é o que torna possível o "molejo" que vemos durante a ginga, a negaça e a agilidade do capoeirista de um modo geral durante o jogo. Ele se configura pelo uso adequado da musculatura do corpo, de modo que não carregue a musculatura com tensão excessiva. $\mathrm{O}$ relaxamento ativo permite também que o movimento seja mais potente, pois a energia é canalizada e aproveitada de forma correta. Neste ponto convém esclarecer o que estamos considerando como potência neste trabalho, a fim de que se tenha maior compreensão do que está aqui sendo exposto. A potência na física é determina pela quantidade de energia concedida por uma fonte para a realização de uma tarefa em um determinado tempo. Dessa forma, a potência se refere à rapidez com que um trabalho é realizado. Temos, assim, que está em questão a quantidade de energia despendida para certa atividade e seu efetivo aproveitamento. Apoiando-nos neste entendimento, consideramos nesta pesquisa como potente o movimento que emprega uma quantidade de energia necessária para sua realização, nem mais nem menos. Portanto, quando dizemos que pretendemos potencializar um movimento, pretendemos fazer com que o fornecimento de energia para a realização deste movimento seja adequado à situação e à necessidade e que o aproveitamento desta energia empregada seja o maior possível. Consideramos esta questão importante, pois é comum vermos iniciantes das artes marciais e atores que engendram um grau de energia enorme para determinado fim, e se veem frustrados quando percebem que não alcançaram o que haviam pretendido e ainda se sentem extremamente cansados. Ou, quando, ao contrário, não empregam uma energia adequada e revelam uma 
apatia quando deveriam estar mais ativos. Portanto, potencializar um movimento ou uma interação significa empregar o grau de energia adequado para que se tire o melhor proveito de cada momento. Neste sentido o relaxamento ativo tem forte relação, pois permite que o corpo esteja livre das tensões desnecessárias, ficando mais aberto e disponível para se ajustar às necessidades de cada momento.

3) Contato com o chão: a relação com o chão é fundamental na "capoeira", uma vez que, estando os pés e as mãos em bom contato com ele, os deslocamentos são mais potentes, as quedas são mais bem amortecidas e o capoeirista tem melhor apoio quando necessita de impulsão. Assim, a conexão com ele deve ser intensa, mesmo nos saltos, quando se perde o contato físico com o chão por alguns instantes.

4) Corpo como um todo: o corpo, considerado em sua unidade física e mental, possibilita a adequada apropriação do movimento a fim de que o "diálogo corporal" flua. A esse respeito Silva explica que "é reconhecendo a unidade psicofísica como modo de ser do organismo que se descobre seu real funcionamento" (SILVA, 2008, p. 24). No momento em que o capoeirista tem a consciência dessa inteireza, ele percebe que o pensamento se dá com o corpo todo e não apenas com o cérebro, melhorando, dessa forma, sua performance. Além disso, a mobilização do corpo como um conjunto permite que os golpes tenham uma potência maior e que o jogador tenha um maior estado de prontidão.

5) Centro de energia: a concentração de energia na direção do centro do corpo para então expandir é uma dinâmica comum na maior parte das técnicas da "capoeira". Temos, como exemplo, a benção onde o praticante recolhe a perna para então estendê-la sobre o peito do parceiro. Na armada, da mesma forma, ao espiralar o corpo, antes de soltar a perna, executa-se um movimento de recolhimento para então liberar a energia e soltar o golpe.

6) Fluxo: a continuidade do movimento promovida especialmente pela ginga é uma das características da "capoeira". O capoeirista não deve parar o jogo a fim de esperar um ataque, ou em razão de uma queda. Ele deve se manter em movimento constante, procurando "ler" o movimento do parceiro e criando 
estratégias. Esta continuidade do jogo propicia a "malícia" que, de acordo com Mestre Pastinha, é um princípio inerente à "capoeira". Segundo este mestre:

(...) a capoeira (...) possui uma qualidade que a torna mais perigosa: é extremamente maliciosa. O capoeirista lança mão de inúmeros artifícios para enganar e distrair o parceiro. Finge que se retira e voltase rapidamente. (...) Gira para todos os lados e se contorce numa ginga maliciosa e desconcertante. (PASTINHA, 1968, p. 33-34)

Nesta dinâmica de simulações com o objetivo de distrair e enganar, está o princípio da mandinga. Esta qualidade de movimentação dá a "capoeira" um fluxo típico que permite uma constante criação de possibilidades corporais durante o jogo. Em relação à noção de fluxo do movimento convém fazermos alguns esclarecimentos sobre a forma como ele foi utilizado nesta pesquisa. Rengel (2005, p. 71) explica "fluxo", a partir da concepção de Laban, como "uma ininterrupta conexão de ações do universo que se dão em tridimensionalidade." No caso da "capoeira" essa ininterrupção se dá fisicamente, de modo que o jogo siga sem pausas ou paradas entre os jogadores. Este foi um tópico desenvolvido com os atores durante o trabalho prático, de forma que eles pudessem experimentar a ideia de continuidade nas experimentações criativas, focando principalmente no conceito de fluência liberada que é um fator de movimento concebido por Laban, 1978, referente a movimentos mais livres, contínuos e expandidos.

Por tudo o que foi aqui exposto, pode-se perceber que, quando tratamos da "capoeira", estamos falando ao mesmo tempo de técnicas definidas e de liberdade criativa, ou seja, identificamos um repertório técnico e artístico que foi definido ao longo de sua história, mas também uma possibilidade de criação e de expressividade pessoal durante o jogo. Este aparente paradoxo que se esclarece na prática, confere a "capoeira" infinitas possibilidades de nuanças e variações, tornando-a uma arte marcial extremamente rica como fonte de preparação corporal e de inspiração criativa. 


\section{Capítulo IV - Aikido}

\subsection{Seu surgimento}

O "aikido" é uma arte marcial japonesa criada pelo mestre Mohirei Ueshiba na década de 1940. De forma resumida, "aikido" significa a busca da harmonia entre o $k i$ individual e o $k i$ do universo. $K i$ pode ser traduzido de muitas maneiras, sendo uma delas "energia", Ai significa "harmonizar" e do quer dizer "caminho". Segundo seu fundador, aiki representa o princípio universal de todas as coisas, é a força que une e harmoniza os elementos do universo. "Aikido", portanto, é o caminho para se harmonizar com o princípio universal. Apesar de ser uma arte marcial relativamente recente, o "aikido" tem suas origens na história antiga do Japão, ficando evidentes a influência da classe dos samurais, surgida da época do Japão Feudal e que seguiam o Bushido, uma espécie de Código de Conduta não escrito. Nessa época, as famílias brigavam por posses de terras e precisavam desenvolver formas de ataque e de defesa para proteger suas propriedades, e/ou, atacar as de outro. Os conflitos eram intensos e frequentes, assim, fez-se necessário o aprimoramento das técnicas de luta. Várias escolas de combate surgiram, uma delas é o Daitoryu Aikijiujitsu, criada por Shinra Saburō Minamoto no Yoshimitsu, do clã Minamoto. O Daitoryu Aikijiujitsu foi uma das fontes que o fundador utilizou para criar o "aikido", sendo, portanto, uma de suas raízes. Além desta escola, o fundador recorreu a outras lutas, as quais praticava com virtuosismo, como o judo, kenjutsu "arte da espada" e jojutsu "arte do bastão curto". Seus sucessores principais foram Kishomaru Ueshiba, seu filho $(1921$ - 1999) e Moriteru Ueshiba, seu neto (1951), que é o atual Doshu do "aikido".

O "aikido" teve seu desenvolvimento até que, com o advento da Segunda Guerra Mundial e a vitória dos aliados, proibiu-se sua prática e de todas as artes marciais no Japão até 1948. Além disso, os líderes da seita Omoto, religião que serviu de base para os conceitos éticos do "aikido", começaram a ser perseguidos e a associação a essa religião se tornou também proibida. Nessa época o "aikido", ainda chamado de

aikibudo, estava em seus primórdios, o que fez com que $\hat{O}$-Sensei - termo que significa "o grande mestre" em japonês -, desejoso de dar continuidade a seu trabalho, migrasse em 1942 para o interior do país, em Iwama, onde construiu um santuário e um espaço para sua prática e aprimoramento. Os treinos eram realizados à noite e sem o uso de iluminação artificial para que não despertasse a atenção das autoridades. Em Iwama o 
fundador alterou o nome aikibudo para "aikido". O "aikido" foi a primeira arte marcial a ser autorizada novamente após o fim da guerra em virtude de sua filosofia pacífica.

Muitas histórias circundam a vida de $\hat{O}$-Sensei, como é conhecido o fundador do "aikido", e todas elas apontam para um homem que dominava muitas artes marciais com virtuosismo, mas, que não tinha desejo íntimo de combater e derrotar o adversário. Uma dessas histórias conta que $\hat{O}$-Sensei praticava artes marciais desde criança e suas habilidades o faziam ser conhecido como o grande guerreiro. Um dia, ao ser visitado por um oficial da marinha, foi desafiado para um duelo de espada. Durante esse duelo, Ueshiba se esquivou de todos os golpes que lhe foram desferidos pelo adversário, alegando depois que conseguia escapar porque percebia os sinais luminosos da espada antes que ela o atingisse. Após várias tentativas frustradas de atingi-lo, o oficial desistiu da contenda. Ao procurar o descanso após esse embate, Ueshiba teve uma iluminação: não há verdadeira vitória quando o resultado é a derrota de alguém. Conta-se que nesse momento começou a surgir o gérmen do "aikido".

Outra história conta que Ueshiba, durante a Segunda Guerra Mundial, estando sob ataque, conseguiu se esquivar de todas as balas que vinham em sua direção, alegando que percebia de antemão a trajetória das balas e, com grande agilidade, conseguia se esquivar delas. Assim como estas histórias, muitas outras permeiam a vida do fundador dessa arte marcial, o "aikido".

A partir de suas experiências e sua forma de perceber a vida, Ô-Sensei objetivou com o "aikido" criar uma modalidade de Budo - via do guerreiro, termo utilizado para designar as artes marciais japonesas - que não recorresse primordialmente à força física e que, sua prática conduzisse os participantes à harmonização com o próximo e o universo. Por esta razão, o "aikido" é considerado uma arte não-competitiva e de cooperação, apesar de ser extremamente eficiente como defesa pessoal, tendo em vista a base que recebeu das artes marciais citadas. Stevens explica que para Ueshiba "bater, ferir ou destruir é o pior pecado que o ser humano pode cometer" (UESHIBA apud STEVENS, 1995). 


\subsection{A dinâmica}

O "aikido" tem como principal movimento o aproveitamento da energia do ataque do parceiro $u k e^{23}$ para contragolpear; ou seja, absorve-se a energia do ataque com a defesa e redireciona-a no contragolpe por meio de movimentos circulares e esféricos que partem do koshi, quadril, em japonês.

O princípio da esfericidade ou espiralidade é altamente relevante nessa prática, uma vez que todas as técnicas de defesa/contragolpe se caracterizam pela trajetória circular e espiralada. É por meio deste princípio que o nage consegue aproveitar a energia de ataque do uke. Nos movimentamos em espiral utiliza-se a força cinética de quem ataca para provocar seu desequilíbrio, ou seja, o nage se "alimenta" da energia produzida pelo ataque para produzir um novo movimento. Isso ocorre principalmente porque, quando o nage se movimenta em espiral, ele suga o uke para seu centro, forma centrífuga, que acaba perdendo seu apoio e, portanto, sua estabilidade. A esse respeito, Ueshiba explica que no "aikido":

Nos movemos em movimento circular em resposta ao oponente e que,
enquanto nos movemos esfericamente, mantemos nosso eixo de
gravidade para criar o eixo estável do movimento.
Concomitantemente, perturbamos o centro do adversário, e quando ele
perde seu centro, perde também todo seu poder. Então é dominado
rápida e definitivamente. (UESHIBA, 2007, p. 55)

A partir da explicação acima, percebe-se que o corpo, durante a realização de uma técnica de "aikido", atua como um pião, rotacionando esfericamente em torno de um centro estável.

Para que todo o processo acima descrito funcione, é necessário que o nage se desloque pelo espaço de maneira correta, partindo basicamente do kamae. Estes deslocamentos são os seguintes:

a) tenkan, que se configura pelo deslocamento em torno do próprio eixo, movimentando a perna posicionada atrás como a ponta móvel de um compasso. Os braços devem acompanhar o movimento das pernas;

23. Neste ponto é importante esclarecer dois termos que serão utilizados com frequência nessa pesquisa: nage ou tori e uke. O uke é a pessoa que desferirá o ataque e o nage é a pessoa que receberá o ataque e contra-golpeará. A relação entre os dois é extremamente importante conforme será percebido ao longo deste processo, uma vez que o Aikido só acontece quando o fluxo de energia entre os dois se instaura. 
b) irimi tenkan, que se assemelha ao tenkan, com a diferença que se deve dar um passo à frente, antes de dar um passo para trás (tenkan). Da mesma forma que no tenkan, os braços devem acompanhar o movimento das pernas todo o tempo.

Esses deslocamentos são importantes, pois eles tornam possíveis os movimentos espiralados. Ao se movimentar em tenkan ou irimi-tenkan o nage cria uma esfera em torno de si, possibilitando que as forças centrífuga e centrípeta ajam a seu favor. Faz-se importante esclarecer que esses deslocamentos podem ser feitos tanto de pé, tatiwasa, quanto de joelhos, suwariwasa. Em todos esses casos os pés devem mover-se deslizando pelo chão, suri ashi, com os joelhos flexionados, pois assim, consegue-se uma maior estabilidade.

A noção de cinesfera já apontada quando tratamos da "capoeira", também aqui tem sua importância, uma vez que, quando são executados esses deslocamentos de forma espiralada, cria-se de forma muito evidente uma esfera imaginária em volta do corpo do praticante. No caso da interação entre $u k e$ e nage, vemos a intersecção dessas esferas por meio do contato físico entre os dois.

Entendemos que, colocando em prática o princípio da esfericidade, o praticante conquista uma grande potência ao aplicar uma técnica, não necessitando de uso muscular excessivo, uma vez que o movimento circular possibilita de forma mais eficiente o aproveitamento da energia do parceiro. Essa dinâmica acontece quando o nage se esquiva agilmente do ataque, redirecionando o impulso recebido pelo uke da forma que for mais apropriada para desequilibrá-lo ou imobilizá-lo.

A respeito disso, Westbrook e Ratti (2006) explicam que o "aikido" consiste, mais precisamente, em movimentos dinâmicos de esquiva, extensão e centralização, que são a base para as ações mais técnicas de neutralização na forma das já famosas técnicas de imobilização e/ou projeção". Neste ponto percebemos uma conexão com as histórias narradas acima a respeito do fundador e suas famosas esquivas. Entende-se, portanto, que, um dos pontos fortes de um bom aikidoista é a agilidade para se esquivar. Nesta arte marcial, não se busca afrontar o parceiro, mas ao contrário, procura-se aproveitar sua energia, cedendo espaço para que ele complete seu ataque e em seguida contragolpear. Este aproveitamento da energia do uke dialoga diretamente com a concepção de não violência que é um dos pilares do "aikido", segundo o qual, ao se defender recorrendo a uma técnica (wasa), procura-se entrar em harmonia com o ataque, transformando as duas partes em parceiros e não em adversários. De acordo com 
esta dinâmica o uke é projetado ou imobilizado sem que isso implique em danos físicos, considerando sempre que as técnicas sejam realizadas respeitando-se os limites de cada corpo. Em razão dos aspectos descritos, o "aikido" é considerado uma arte de autodefesa sofisticada, em que o ataque é neutralizado, porém, sem o uso de meios brutais e violentos.

O princípio da esfericidade foi utilizado como inspiração para a criação de procedimento com os atores objetivando:

aprimorar a conscientização do próprio corpo e a postura com a reorganização da coluna e das extremidades e com a utilização de tônus adequada;

potencializar a relação com o espaço uma vez que o movimento espiralado permite o deslocamento pelo espaço e todas as direções;

o contato consciente com o parceiro, considerando que ao movimentá-lo de forma circular o praticante não pode fazer uso errado da musculatura.

Ao discorrer sobre a dinâmica do "aikido" mencionamos três termos que merecem ser melhor desenvolvidos por serem a base desta arte marcial: ki e koshi.

Entendemos que o ki pode ser traduzido como "energia" e "espírito"; todavia, estes termos são muito reducionistas e não esclarecem o que vem a ser o $k i$, seu significado é muito mais complexo. Segundo Ueshiba (1984, p. 29) "no coração do “aikido"está como caminho espiritual o $k i$, a energia que forma o mundo e que também se forma no âmago de cada ser humano, esperando ser percebida e realizada". Em diversas escolas de pensamento chinesa e japonesa o $k i$ é considerado "o princípio essencial da harmonia", "a fonte da criatividade expressa no ying e yang", "a plenitude vital”, "a força divina que penetra todas as coisas", "o vazio", "a energia modeladora que emerge do caos", "o princípio dualista da estrutura do universo que opera como escuridão e luz, força e suavidade" (UESHIBA, 1984). O autor segue explicando que:

Embora o conceito do ki tenha origem nos pensadores fecundos da antiga China (...) ele não se limita a eles, pois passou por mudanças na evolução da história (...) Depois de ser introduzido no Japão, esse conceito interagiu com o ethos nativo para formar uma visão de mundo típica que inclui atitudes com relação à natureza, à vida, à morte e assim por diante". (UESHIBA, 1984, p. 29)

$\mathrm{Na}$ era dos samurais esse conceito também se ligou aos termos de "coragem", "força de vontade" e "bravura". 
Percebemos pelo exposto, que a noção de $k i$ deixa clara a ideia de que, para o oriental, tudo o que existe está conectado e encadeado, desde o movimento mais íntimo do ser humano até o maior movimento do universo. E que o ki é esta força que nos mantém vivos e saudáveis e em contato com o mundo que nos cerca. É uma troca constante de energia que une os opostos harmonizando-os e que potencializa cada ser humano.

Seguindo essa ideia, o fundador via o Budo "arte do guerreiro", como forma de treinar o corpo e apreender a verdadeira natureza do universo, defendendo que:

Os seres humanos devem unir mente e corpo, e o ki que liga ambos, e então alcançar a harmonia com a atividade de todas as coisas do universo. Em virtude da sutil atividade do $k i$, harmonizamos a mente e o corpo e a relação entre o indivíduo e o universo. (UESHIBA, 1984, p. 33)

Ueshiba reforça neste trecho a conexão entre mente e corpo defendida também por Merleau-Ponty e Noe, apontadas anteriormente. Também para ele a força de cada ser humano está na integralidade do conjunto corporal. Dessa forma, o trabalho com o ki tem como objetivo o constante reequilíbrio corporal em todos os seus aspectos psicofísicos. O fundador, dessa forma, ao criar o "aikido", pensou nesta arte como uma ferramenta que possibilitasse uma maior consciência da relação mente-corpo, indivíduouniverso e potencializasse esse fenômeno. Ueshiba reforça ainda que a unidade mente e corpo, possibilitada pelo $k i$ e manifestada por aiki (harmonização do ki), provoca mudanças sutis na pulsação fazendo com que a técnica wasa flua livremente. Como a pulsação afeta todos os espaços do corpo, sua alteração faz com que a pessoa fique com mais vitalidade, sendo capaz de realizar movimentos mais variados e dinâmicos. Acrescente-se ainda que o ki flui do centro de gravidade do corpo, que é forte e estável, para as extremidades, fazendo com que os braços e as mãos se transformem em uma espada, tegatana. Vários exercícios durante os treinos têm como objetivo trabalhar com essa expansão de energia como o kokyo ho. Além disso, muitas técnicas do "aikido" operam a partir do princípio de que o braço e a mão assumem a firmeza de uma espada. 
Imagem 16: tegatana, mão de espada

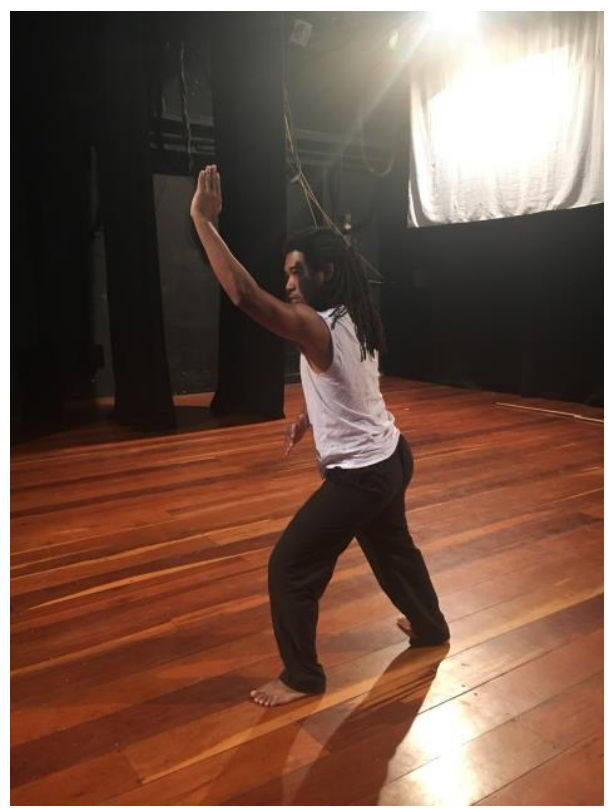

Fonte: arquivo do autor.

Acerca da união corpo-mente, essencial para o entendimento do $k i$, muitos pesquisadores e praticantes dessa arte marcial reforçam a importância dessa conexão como Bull (2003, p. 102) explica que, quando esse fenômeno ocorre "o corpo se transforma em uma espada que corta ou em um aspirador que suga o oponente".

Convém ainda acrescentar que o estado de atenção e prontidão decorrentes da união corpo-mente pode ser explicada como vários círculos concêntricos que se afetam e se comunicam da seguinte forma:

1. Em torno de si próprio: antes de se colocar em relação ao outro, o aikidoista deve estar em comunhão consigo mesmo. Isso quer dizer que o praticante deve estar concentrado, relaxado e com boa autoconscientização corporal.

2. Na relação com o outro: quando o nage é atacado pelo uke com um atemi (soco ou chute, por exemplo), ele deve estar apto para reagir a este ataque com o máximo de antecipação possível. Esta antecipação é conseguida direcionando a atenção ao corpo do uke como um todo, e não para apenas uma parte. Temos, assim, o segundo círculo de atenção: envolvendo o uke e o nage. 
3. Relação com o espaço: o nage não pode perder de vista que está inserido em um espaço delimitado, com características próprias e compartilhado por outras pessoas, devendo, portanto, ampliar sua percepção para estes elementos também. Temos, portanto, outro círculo maior, abarcando os três outros menores.

Convém ressaltar que um círculo não é mais importante que o outro. Ao contrário, todos devem se complementar para que o estado de prontidão do nage seja o mais eficaz possível.

A respeito desse tema, convém complementar ainda que o uke, da mesma forma que o nage, precisa "ativar" esses círculos, pois deve estar em comunhão consigo próprio desde antes do ataque (1. ${ }^{\circ}$ círculo), deve estar atento ao corpo do nage como um todo para que possa interagir com o movimento desse $\left(2{ }^{\circ}\right.$ círculo), e, por fim, não pode perder de vista o espaço que o envolve (3. ${ }^{\circ}$ círculo), pois está lidando com quedas, imobilizações e lançamentos que podem ferir se o seu grau de atenção não for adequado.

Percebemos, dessa forma, que quando falamos em corpo na prática do "aikido", nos referimos a ele como algo único, sem separação da mente e do físico, afetado pelo entorno e em conexão com tudo que o cerca, reforçando, assim, a ideia de que tudo o que existe no universo está conectado em unidade. Para que nos beneficiemos dessa integração, basta que tenhamos consciência dela e, por meio de nosso corpo, consigamos acessá-la, nos abrindo para novas possibilidades.

Defendendo ainda a noção de unidade corporal, o filho do fundador do "aikido" explica que:

O fato é que o corpo todo, não apenas os braços e as pernas devem mover-se continuamente de uma maneira coordenada, e isso deve ser feito com rapidez, vigor e potência. É necessário um grau extraordinário de concentração mental e de agilidade, de equilíbrio e de reflexos para atuar com suavidade e rapidez. (UESHIBA, 2003, p. 26)

Ueshiba, 2003, aponta tanto para a união psicofísica como para a integração das partes físicas do corpo, argumentando que o corpo em si deve também ser entendido como um todo, em que todas suas partes estão encadeadas em um conjunto harmônico. Esta unidade em torno de um centro estável e forte é essencial para a execução de qualquer técnica com eficiência. Assim, se o nage ao tentar deslocar o uke com a 
técnica daiti kyo, por exemplo (foto a seguir), utilizar apenas os braços ignorando o potencial do restante do corpo, precisará empregar uma força muscular excessiva e correrá o risco de ter seu objetivo frustrado caso o uke seja mais forte, pois possivelmente não conseguirá deslocá-lo de seu eixo. Isso ocorre porque as outras partes do aparato físico do nage não foram mobilizadas adequadamente.

\section{Imagem 17: daiti kyo omote}

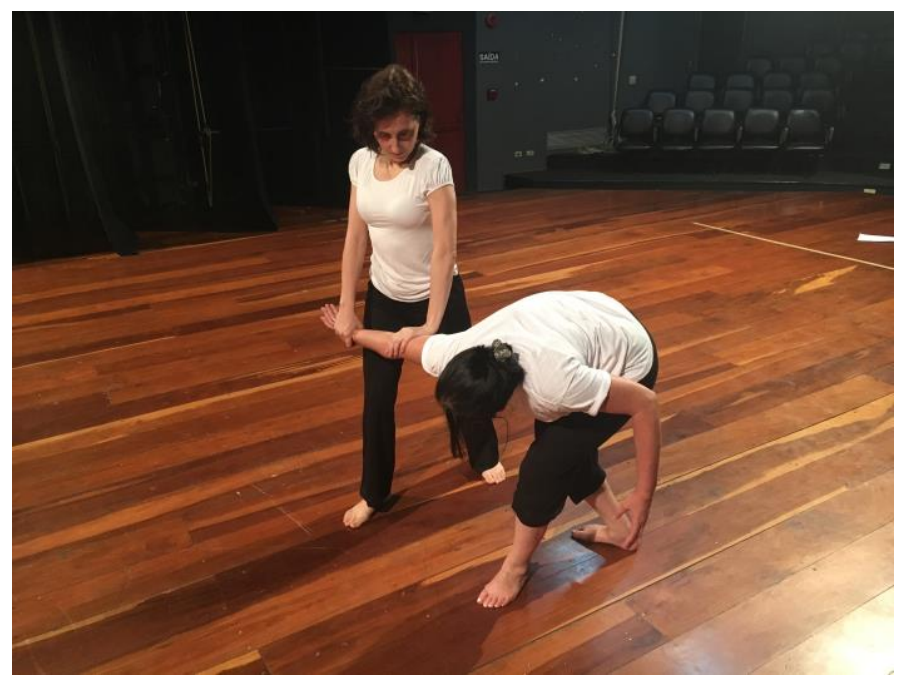

Fonte: arquivo do autor.

Bull, reforçando a ideia de todas as partes do corpo trabalhando em sintonia, explica que:

Quando observamos os movimentos de dedo, pulso e quadril, todos coordenados com a respiração, vemos que eles estão em conformidade com os ideais de aprimoramento físico. Os movimentos de todas as partes do corpo estão unificados em um todo sistematicamente controlado. (BULL, 2003, p. 58)

A partir dessa citação identificamos outro ponto de apoio para entender o ki que é a respiração, pois é por meio dela que o praticante consegue chegar em um estado de relaxamento ativo, podendo atuar com prontidão e flexibilidade. A respiração no "aikido" é mais do que o ato mecânico de inspirar e expirar, é também a forma de se recarregar, absorver a energia do universo e, dessa forma, se conectar com o parceiro e com o que estiver à volta. Morihei Ueshiba nesse sentido explica:

Pensem sobre o fluxo e o refluxo das ondas. Quando as ondas batem na praia, elas se encrespam e se desfazem, gerando um som. A respiração de vocês deve seguir o mesmo padrão, absorvendo o 
universo inteiro em seu ventre em cada inalação. Saibam que todos temos acesso a quatro tesouros: a energia do sol e da lua, a respiração do céu, a respiração da terra e o fluxo e refluxo das ondas. (UESHIBA apud STEVENS, 2007, p. 62)

Ô-Sensei deixa claro com esta assertiva que, por meio da respiração, nos conectamos com a energia que compõe todo o universo, pois nos integramos a um todo que não é estranho a nós, mas é também parte de nós mesmos, necessitando apenas ser acessado. Seguindo esse raciocínio, apoiando-se na respiração, o aikidoista consegue executar os movimentos com mais eficiência, aprimorando sua técnica e evitando lesões em si e no parceiro. Temos, portanto, que a respiração, por meio desse fluxo que se assemelha ao movimento das ondas, auxilia o aikidoista a se preparar de uma forma ampla desde suas necessidades mais pessoais até a potencialização das relações com o parceiro e com o entorno.

Ao tratarmos da integração de todas as partes do corpo no "aikido", não podemos deixar de reforçar e importância do koshi, quadril em japonês, que é considerado a alavanca mais potente do corpo humano e é de onde parte a principal energia $k i$ que conduzirá o restante do corpo. É nesta região que se localiza o hara, considerado pelos japoneses como sendo o centro vital do corpo, o centro de gravidade, o centro físico-espiritual do ser humano. O koshi tem uma importância tão grande para a cultura japonesa, especialmente para as artes do corpo, que no Teatro No, quando se diz que a pessoa tem koshi, significa que ela tem energia e, quando se diz que ela não tem $k o s h i$, significa que ela não tem energia. É a partir do quadril que todo o restante do corpo será mobilizado de forma adequada, tornando-se um todo que se move em um conjunto harmônico. Sua conexão com o ki também é inevitável, pois se entende que é dele que toda a energia flui, sendo irradiada para as extremidades. No "aikido", utilizando-se corretamente o poder de alavanca do koshi, desloca-se o parceiro com mais facilidade e menor esforço. Este é um dos grandes segredos desta arte.

A título de esclarecimento, convém explicar como se processa a alavanca. A alavanca constitui-se de uma máquina utilizada para auxiliar na elevação, carregamento e movimentação de objetos pesados, pois tem o poder de multiplicar a força mecânica que pode ser aplicada a outro objeto. A respeito de sua função Arquimedes teria dito certa vez: "Se me derem uma alavanca e um ponto de apoio, deslocarei o mundo". A alavanca parte de três elementos: PA - Ponto de apoio: o ponto ao redor do qual a alavanca pode girar; FR - Força resistente: Peso do objeto que se pretende movimentar; FP - Força potente: Exercida com o objetivo de mover o objeto. Estabelecendo um 
paralelo com a prática do "aikido", podemos dizer que o koshi funciona como um desses pontos de apoio, sendo o uke o objeto que se pretende movimentar. Como exemplo disso podemos citar o koshinage (foto a seguir) que é uma técnica em que se objetiva tirar o uke do chão e derrubá-lo, conforme se observa na figura abaixo. O nage posiciona seu koshi próximo ao koshi do uke, pois assim, ele usará a força dessa articulação para levantar o parceiro por seu centro de gravidade, o que torna o levantamento mais fácil. A respiração nesse processo tem uma função importante, uma vez que, ao expirar no momento de levantar o parceiro, o movimento se torna mais potente.

\section{Imagem 18: koshinage}

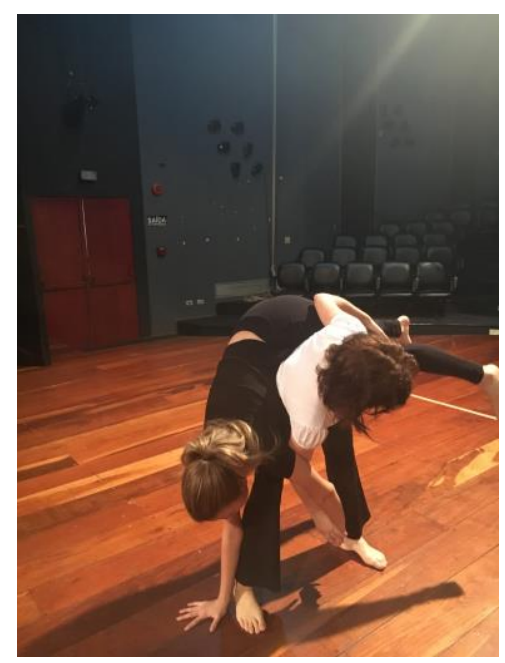

Fonte: arquivo do autor.

O próprio Hakama, vestimenta de treino dos Yudansha, faixas pretas, tem como uma das funções tornar mais eficiente o movimento do quadril uma vez que, com o Koshi Ita - parte posterior do hakama próximo à lombar - protege-se a lombar posicionando-a de forma correta e possibilitando a movimentação do koshi para todas as direções.

Ainda acerca do conjunto corporal que tem como centro o koshi, não podemos deixar de lembrar as articulações que na execução das técnicas tem grande importância, já que elas têm como objetivo suavizar os impactos e flexibilizar os movimentos do corpo, deixando-o mais maleável.

Cada articulação está associada a um músculo, por meio dos tendões conectivos que os prendem. Portanto, quando utilizamos um número grande de articulações estamos trabalhando com uma cadeia muscular maior e, portanto, o movimento tem 
mais potência. Os braços, as mãos e as pernas possuem articulações que podem dar mais eficiência ao movimento, conforme observamos na técnica daichikio, que forma uma trava que, em conexão com o koshi, imobiliza o uke. Podemos citar também os joelhos que permitem um bom amortecimento de impactos ao se flexionar e uma maior mobilidade corporal. Percebemos essa mobilidade, por exemplo, no kamae, que é a base de forma triangular e que dá estabilidade ao corpo. Por fim, temos também as torções como sankyo, nikkyo e kotegaeshi, que são infligidas sobre as articulações dos membros superiores do uke, a fim de que seja possível imobilizá-lo e deslocá-lo enquanto é promovido o alongamento de suas juntas.

Imagem 19: kamae

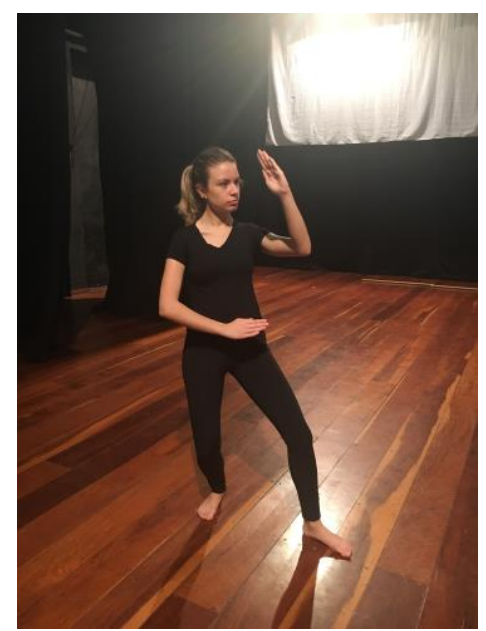

Fontes: arquivo do autor.
Imagem 20: sankyo

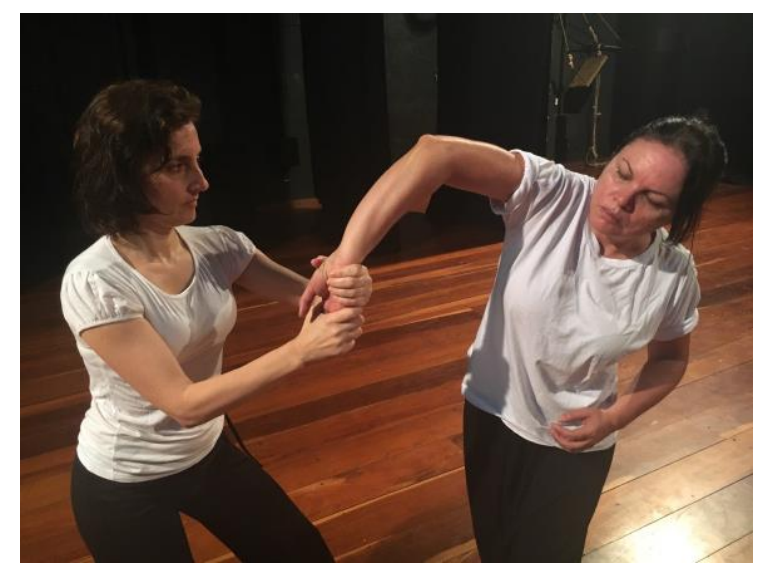

Imagem 21: nikkyo

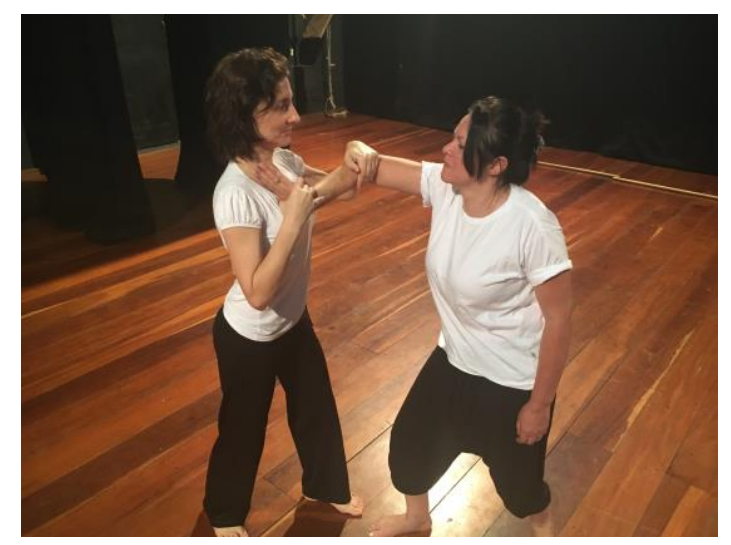

Fontes: arquivo do autor.
Imagem 22: kotegaeshi

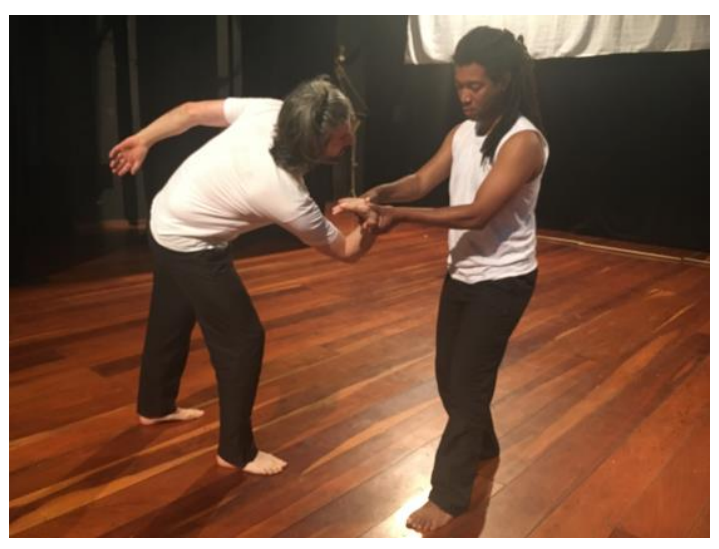


Ao serem torcidas essas articulações, o corpo inteiro se torce por sofrer os reflexos da torção, ficando clara a conexão de todas as partes do corpo. Ô-Sensei afirmava, de forma metafórica, que os exercícios de articulação em técnicas de imobilização servem para remover a poeira que se acumulou nas juntas (BULL, 2003). Mas, é importante lembrar que esse benefício só acontece se o nage estiver atento aos limites do parceiro, caso contrário, pode provocar sérias lesões como inflamações e fraturas.

Por fim, ao tratar das articulações, não podemos deixar de mencionar o shiko, uma técnica de caminhar sobre os joelhos que pode ser utilizado para a execução de todas as técnicas. Ou seja, as mesmas técnicas catalogadas do "aikido" podem ser realizadas a partir do kamae - tati wasa - como podem ser realizadas em shikosuwariwasa.

\section{Imagem 23: shiko}

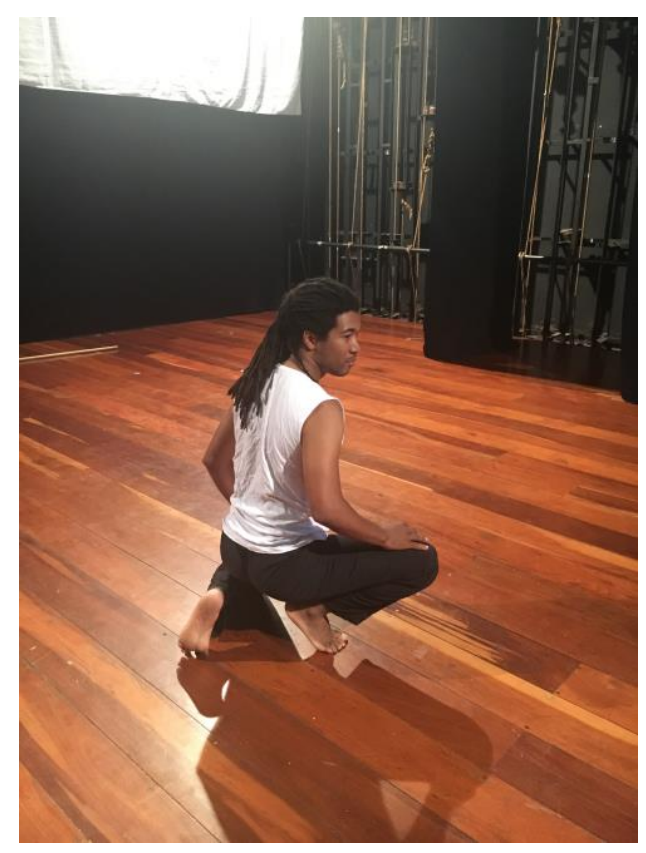

Fonte: arquivo do autor.

A origem do shiko é nebulosa, existindo algumas histórias que tentam elucidá-la. Uma delas explica que os samurais, especialmente em época de guerra, necessitavam estar preparados todo o tempo para o embate, inclusive quando estavam em momentos de descanso ou na hora da refeição. Ter agilidade e destreza para lutar nessa posição era essencial para a sobrevivência. Outra explicação é a de que, ao fazer demonstrações perante ao imperador, os lutadores não podiam ficar em um nível acima dele e, por esta 
razão, lutavam sobre os joelhos. Independentemente de qual versão seja verdadeira, é importante observar que esta técnica, além de ampliar as possibilidades de exploração do espaço, se conecta diretamente com o contexto cultural que originou o "aikido".

Todos os aspectos do "aikido" aqui apresentados como a integração corporal, tanto no que diz respeito à unidade psicofísica como à conexão entre as partes físicas, o uso adequado da respiração potencializando o movimento e a concentração, a expansão do $k i$, a relação com o espaço por meio da esfericidade, a conexão entre os parceiros aproveitando-se a energia gerada pelo movimento, o uso do koshi como potente alavanca e o uso das articulações, foram utilizados como recursos para a elaboração de exercícios com os atores visando o autoconhecimento, a criação de movimentos mais expressivos, a potencialização da relação entre os parceiros e a instauração de relaxamento e tranquilidade o que permite a ampliação da criatividade.

\subsubsection{Relação uke-nage}

Procuramos expor anteriormente que é na expansão do $k i$, na conexão e afetação mútua entre o ataque e a defesa uke/nage, na mobilidade do koshi e na movimentação esférica e espiralada que os aspectos relacionais do "aikido" se fundamentam. Entretanto, em virtude da importância da relação entre o uke e o nage para esta arte marcial, faz-se importante ainda desenvolver este tema mais detalhadamente.

Um aspecto ainda não abordado de suma importância para que essa relação se instaure é o maai - um termo japonês para designar o espaço ou a distância entre os dois parceiros. A escolha da estratégia a ser utilizada pelo nage dependerá muitas vezes do maai. A distância entre ambos pode impulsionar o movimento, como pode também dificultar ou até mesmo impossibilitá-lo. Perceber essa distância é fundamental. Podemos dizer, dessa forma, que essas percepções favorecem a harmonia espacial entre os praticantes.

Outro elemento importante nessa relação é o aproveitamento da energia do $u k e$ pelo nage em movimento espiralado, a fim de que, desequilibrando o uke, o nage consiga projetá-lo ou imobilizá-lo. Na interação entre estas duas partes, identificamos dois tipos iniciais de contato: o rígido e o flexível. No rígido, o uke "prende" o nage de uma forma específica, que pode ser tanto pela frente segurando-o pelos punhos ou pelo dogi (vestimenta utilizada para o treino), ou por trás, pelo pescoço (enforcamento), pelos punhos ou pelo dogi. No flexível, o ataque é realizado em movimento com o 
desferimento de um soco ou de um chute pelo uke ou pela tentativa de apresamento pelo punho do dogi ou pescoço do nage. No caso, se deve esquivar antes de ter a mobilidade comprometida. Neste processo a "escuta" entre os dois parceiros é fundamental, pois, somente com esta sintonia, o diálogo corporal pode acontecer.

Nos dois tipos de ataque descritos acima, rígido ou flexível, utilizamos o mesmo processo de aproveitamento de energia do parceiro por meio de movimentos esféricos. Entretanto, algumas diferenças devem ser destacadas:

1. O estado inicial do nage é alterado, uma vez que, nas técnicas rígidas, quando está preso pelo uke, o nage deve se livrar de uma quase imobilização, enquanto no flexível ele está inicialmente livre, podendo dispor de seus movimentos de modo mais solto;

2. A qualidade da energia mobilizada pelo uke no ataque inicial é diferente, uma vez que, nas técnicas flexíveis ele recorre a movimentos ágeis e rápidos, enquanto nas rígidas, o uke pode fazer mais uso da força muscular.

Por esta diferenciação podemos compreender quais os tipos de movimento que são empregados pelos praticantes, dependendo da posição que estiver ocupando, de modo a perceber o grau de engajamento muscular, a forma de contato com o parceiro e o nível de energia utilizado. A necessidade de apontar esta diferença neste trabalho não decorre apenas de esclarecer um aspecto do "aikido", mas de apontar possibilidades diferentes de contato entre os parceiros que implicam em formas diversas de mobilizar o corpo. A relação é um dos focos desta pesquisa, assim, este aspecto foi levado em consideração no trabalho com os atores, de forma que eles se sentissem estimulados a experimentar diferentes possibilidades de abordagem e de aproximação do outro. Estas variações, portanto, influíram na condução dos exercícios práticos servindo como material tanto para a fase de preparação como de criação.

É importante reforçar que na relação instaurada entre uke e nage, independentemente do tipo de ataque, a cooperação entre ambos deve estar sempre presente, uma vez que, o "aikido" não é uma arte marcial que visa derrotar o oponente. Neste ponto podemos observar que quanto mais flexível for o uke, mais circular e continuado será o movimento da dupla. Ao passo que, quanto mais inexperiente e duro for o $u k e$, a probabilidade é de que sejam mais truncados os movimentos. Entende-se, portanto, que a eficiência, a plasticidade e a fluidez das técnicas dependem 
sobremaneira da parceria e da mútua cooperação entre uke e nage. Como consequência desse pensamento, durante os treinos, as posições de "ataque" e de "defesa" se alternam constantemente entre os praticantes, a fim de que todos possam passar pelas duas experiências e assim, aprimorar habilidades inerentes a cada posição.

A respeito da cooperação, certa vez o fundador teria dito a seus alunos:

Na verdade - eu não tenho alunos - vocês são meus amigos, e eu aprendo com vocês. Devido ao seu treinamento vigoroso, eu cheguei até onde me encontro hoje. Serei sempre grato pelos seus esforços e cooperação. Por definição, aikido significa cooperar com todos, cooperando com os deuses e deusas de cada religião. (STEVENS, 2001, p. 17)

Ueshiba segue defendendo que:

No verdadeiro Budo, não existem inimigos. O verdadeiro Budo é a função do amor. O Caminho do guerreiro não é a destruição e a morte, mas experimentar a vida para continuamente criar (...) O amor gera o calor e a luz que alimentam o mundo. (STEVENS, 2001, p. 22)

Convém ressaltar ainda que a interação uke-nage só ocorre porque existe a complementaridade entre ambos. Cada um apresenta uma característica particular que faz com que o contato harmônico ocorra. Entendemos esta complementaridade como a relação entre ying e yang da filosofia chinesa - que mencionamos rapidamente quando tratamos do ki. É da conexão entre o forte e o suave, o agressivo e o tranquilo, a escuridão e a claridade que surge o "aikido".

A partir do exposto, em resumo podemos dizer que as seguintes características são encontradas durante a prática do "aikido" no que diz respeito às qualidades da energia empregada pelos praticantes: quando o uke inicia um ataque, emprega um esforço muscular maior, forte e vigoroso. O nage, ao contragolpear, utiliza tônus leve e vigoroso, em estado de relaxamento ativo, já definido anteriormente como o estado corporal em que as tensões estejam adequadamente distribuídas pelo corpo, de acordo com a necessidade de cada momento. Assim, tal qual a "capoeira", este estado é bastante ressaltado na prática do "aikido". Westbrook e Ratti (2006, p. 90), corroborando com este entendimento, explicam que o relaxamento ativo não significa "uma condição desfalecida, fraca ou letárgica, mas um estado de maleabilidade e flexibilidade serena muscular que permite uma reação sem prejuízo em qualquer direção, à primeira indicação de um movimento agressivo". É com este nível de 
relaxamento que se chega à prontidão, agilidade e flexibilidade necessárias para que a relação se efetive de maneira harmônica.

Outras características que podemos identificar no uke e no nage, que os diferem e ao mesmo tempo os complementam estão descritas a seguir.

No nage:

a) os movimentos partem do centro para as extremidades;

b) a base é sempre equilibrada e estável;

c) o nage usa a força centrípeta, trazendo o uke para seu centro e então o desequilibrando-o, utilizando movimentos circulares e espiralados;

d) a coluna vertebral funciona como o eixo da esfera. A esse respeito, a fim de explicar esta afirmação, recorreremos às palavras do Sensei Lemos (Sensei de Aikido filiado à FEPAI), proferidas no III Encontro de aikidoístas de Campos do Jordão (2007):

O corpo pode ser comparado a uma bandeja que é carregada repleta de copos. A bandeja deve manter equilibrados os copos que estão sobre ela; caso vire ou desequilibre, os copos caem; mas caso mantenha-se equilibrada os copos também se mantêm. Assim deve ser o corpo do nage durante a execução da técnica. O quadril é como a bandeja que equilibra o restante do corpo que está acima, a exemplo dos copos sobre a bandeja.

e) movimentos de contragolpe devem partir de uma postura relaxada ativamente;

f) a respiração potencializa a eficiência das técnicas.

No uke observamos o seguinte:

a) durante a relação com o nage, seus movimentos fluem da extremidade para o centro, já que ele é sugado pelo nage; b) sua postura começa estável, mas vai aos poucos perdendo o equilíbrio até que chega a queda; c) o corpo começa com o uso de tensão muscular grande, em razão da energia empregada no ataque, mas vai tendo essa energia transformada durante a conexão com o nage; d) as articulações são torcidas ou imobilizadas durante a aplicação da técnica; e) A respiração ajuda no relaxamento, o que faz com que as torções e as imobilizações sejam menos doloridas e as quedas e rolamentos mais suaves. 
Temos, dessa forma, duas pessoas com duas propostas corporais opostas, que interagem e que, nesta interação, sem perder suas particularidades, chegam a um resultado plasticamente belo e fluido.

Consideramos pertinente descrever tecnicamente alguns aspectos da relação entre uke e nage de forma mais detalhada, não apenas para que o "aikido" fosse melhor compreendido, mas, também porque estes elementos serviram de base para a sistematização de diversos procedimentos utilizados com os atores, especialmente no que diz respeito ao uso do espaço, às formas de contato com o parceiro e às variações de energia e movimento. Esta gama de possibilidades extraídas do uke e do nage auxiliaram aos atores a ampliar seus repertórios, fazendo com que tivessem mais apoios e referências para se expressar criativamente.

\subsubsection{Fundamentos}

Até o momento procuramos expor de que forma se processa a prática do "aikido" e quais os principais elementos de sua dinâmica. Todos esses elementos podem ser observados em todas as técnicas dessa arte marcial, uma vez que elas têm como objetivo fisicalizar os princípios filosóficos que fundamentam, o “aikido". Acerca desses fundamentos, Stevens, 2001, apresenta dez pilares que seguem expostos abaixo:

1. Shiho. Universalidade. Shiho significa quatro direções. A partir do movimento shihonage podemos perceber a aplicação desse conceito na prática. Nesta técnica o nage realiza um deslocamento no espaço em quatro direções, terminando com a imobilização do $u k e$ depois de ter efetuado uma torção em um dos braços. Estas quatro direções representam a possibilidade de se movimentar em todas as direções, percebendo o que está à volta por todos os ângulos. Além disso, há quem estabeleça relação com as quatro virtudes e com as quatro gratidões. ${ }^{24}$

24. Quatro virtudes: conhecimento, crescimento, liberação e força. Quatro gratidões: gratidão para com o universo e a vida, para com nossos ancestrais, para com o próximo, para com os animais e plantas que nos sustentam. 


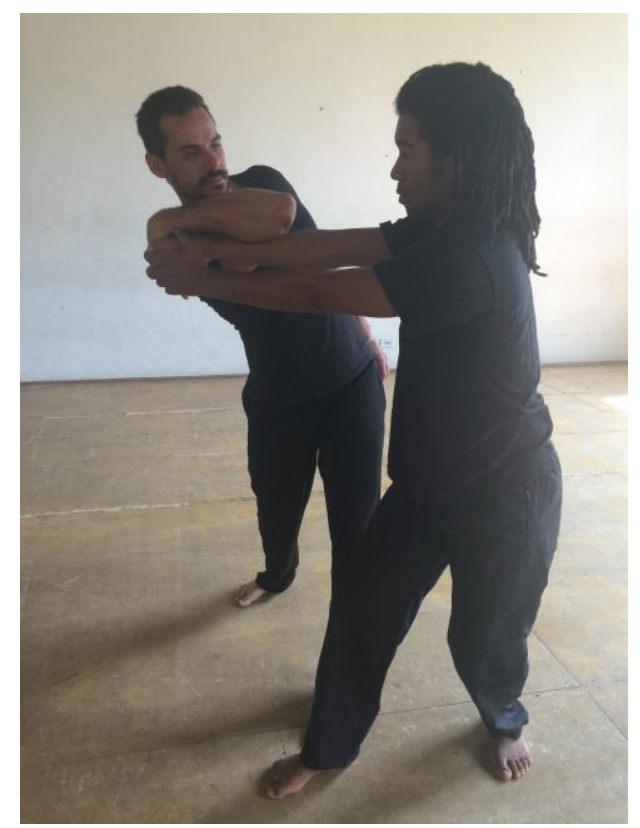

Fonte: arquivo do autor.

2. Irimi. Avançar e unir-se. Diante de um ataque, muitas vezes a melhor saída é se aproximar do atacante ao invés de afastar-se dele. Quando o nage se aproxima do uke, possibilita a harmonização das forças opostas, neutralizando o ataque. O iriminage (foto a seguir) é uma das técnicas básicas catalogadas que coloca em prática este conceito. Nesta técnica o $u k e$ se desequilibra porque o nage entra em seu ponto cego, atraindo-o para seu centro, assumindo, dessa forma o controle sobre seu movimento. Como consequência, o uke perde seu apoio e cai.

Imagem 25: iriminage

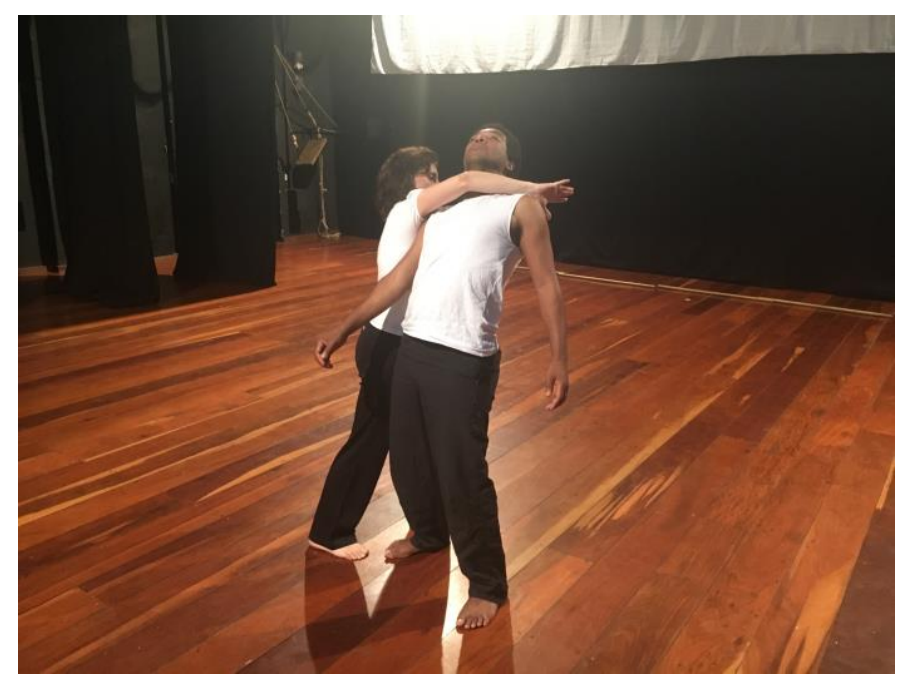

Fonte: arquivo do autor. 
3. Kaiten. Abrir e girar. Quando se recebe um ataque, às vezes faz-se necessário sair, abrir para o lado para então contragolpear redirecionando o movimento para cima do uke, como o que ocorre no uti mawashi kaiten nage. Pela figura pode-se observar a saída para a lateral do nage e a volta projetando o uke para frente. Filosoficamente, este conceito tem a ver principalmente com a ideia de que devemos nos abrir para as possibilidades do mundo, lidando com as coisas a volta de "coração aberto" e sem resistências.

Imagem 26: Uti mawashi kaiten nage omote

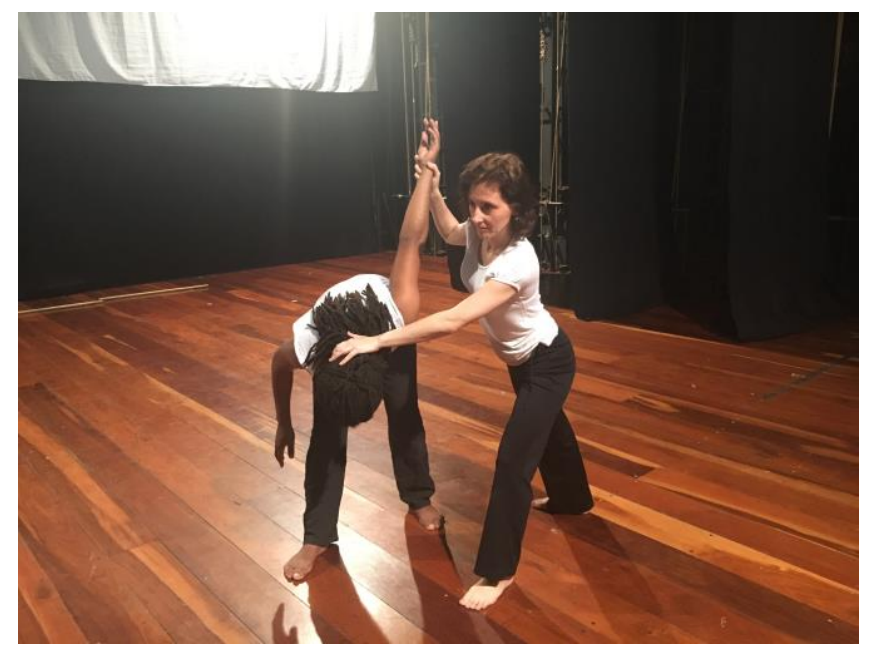

Fonte: arquivo do autor.

4. Kokyu. Respiração. Já mencionamos anteriormente a importância da respiração tanto para a prática eficiente da arte marcial como para uma vida cotidiana saudável. É pela inspiração e expiração que nos carregamos de energia e nos colocamos em estado ideal para enfrentar com tranquilidade os percalços. No "aikido" procuramos exercitar a respiração durante a realização das técnicas, a fim de que ocorra uma compreensão completa deste conceito. O kokyo nage, por exemplo, é uma técnica básica na qual o bom uso da respiração é essencial. Nesta técnica, inspiramos quando nos aproximamos do $u k e$ e expiramos quando o desequilibramos. 
Imagem 27: kokyo nage

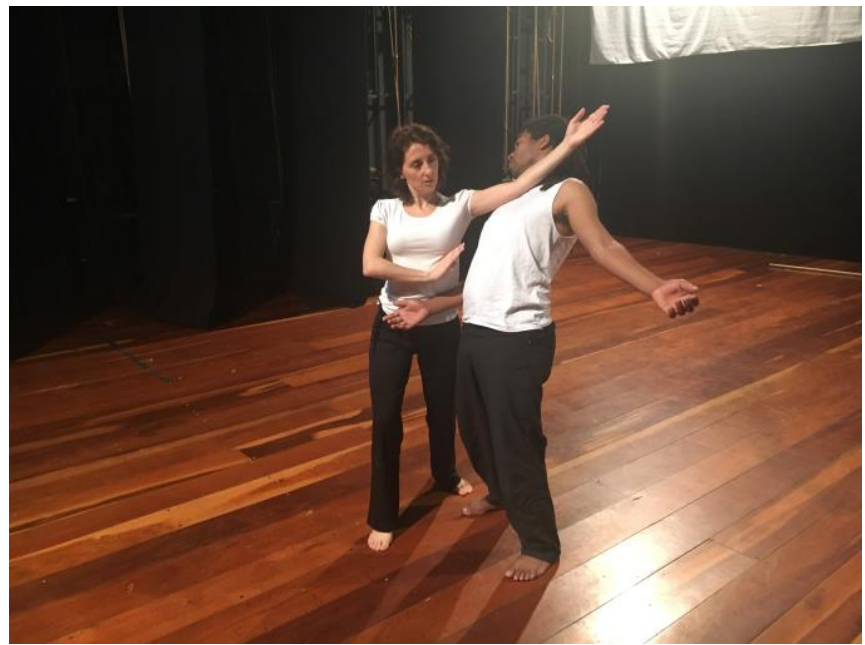

Fonte: arquivo do autor.

5. Osae. Autocontrole e controle da situação. Quando aplicamos uma técnica temos que manter dois focos: a) fazer o movimento controladamente para não lesionar o parceiro e b) manter a situação dentro de um limite controlável e seguro. Quando conduzimos o ataque do parceiro de modo que o movimento seja concluído com uma imobilização, ou seja, prendendo o uke no chão, é uma forma de manter a situação dentro de um limite controlável pelo nage.

Imagem 28: imobilização

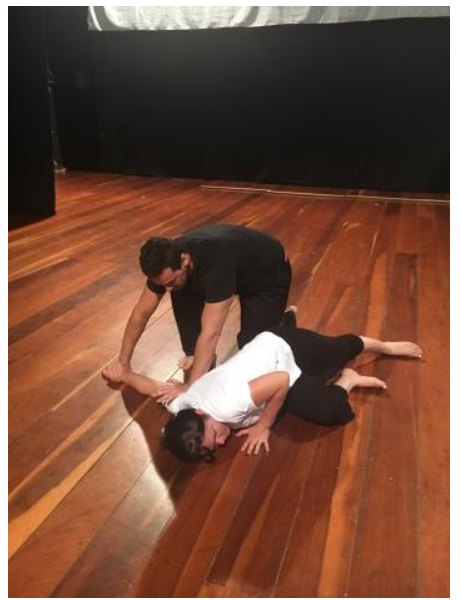

Fonte: arquivo do autor.

6. Ushiro wasa. Lidar com o desconhecido. No "aikido" alguns ataques são executados por trás o que ajuda a treinar o contragolpe contra o que não 
se vê. Filosoficamente pretende-se preparar os praticantes contra as adversidades inesperadas, tornando-os mais ágeis diante de algo novo e inusitado.

Imagem 29: ushiro

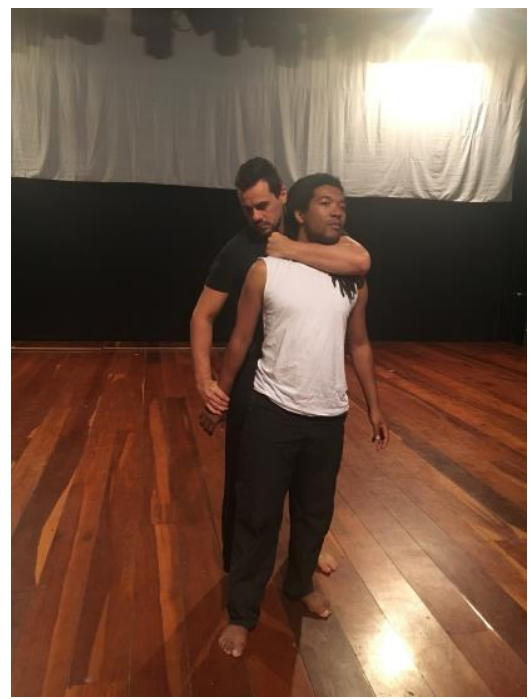

Imagem 30: ushiro

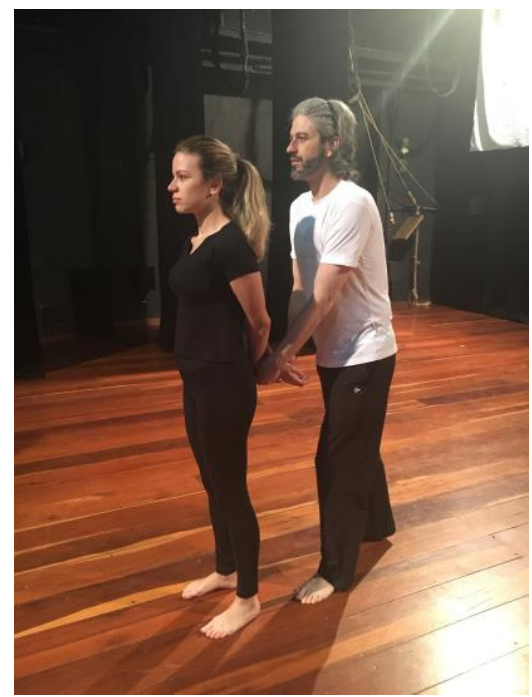

Fontes: arquivo do autor.

7. Tenchi. Conexão entre o céu e a terra. $\mathrm{O}$ céu representa o vazio e a terra a matéria. Na junção destes dois elementos temos a completude. Assim, por meio desta conexão nos tornamos mais plenos. O tentinage (foto a seguir) é uma técnica que faz com que este conceito tome forma, ficando mais visível para quem pratica e observa. Enquanto se avança para o uke, um braço segue firme em direção a terra e o outro firme em direção ao céu, provocando o desequilíbrio do parceiro.

Imagem 31: tenti nage

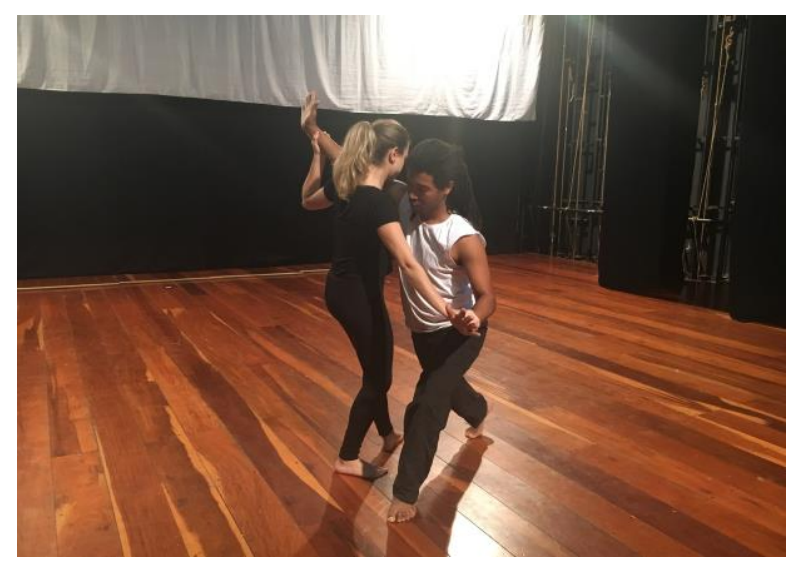

Fonte: arquivo do autor. 
8. Aiki ken e Aiki jo. Espada e Bastão. Resolução e intuição. Embora a maior parte das técnicas do "aikido" seja a partir das mãos livres, existem movimentos, tanto para o uke como para o nage que são realizados com o boken, katana de madeira, e com o jo, bastão de madeira.

O jo e o boken devem ser sempre segurados com ambas as mãos, partindo-se da posição de kamae. Os joelhos devem ficar ligeiramente flexionados para favorecer a agilidade do quadril e a estabilidade. Os movimentos da espada são retos e diretos, sendo associados à determinação e a ideia direcionada. Já as técnicas com o jo são circulares, flexíveis, se movimentando para cima e para baixo, representando a intuição e a atuação flexível diante de um obstáculo. As técnicas de ambas as armas combinam ataque e defesa simultaneamente e devido à esfericidade da trajetória executada reduz-se o caráter de conflito (BULL, 2006).

A prática com essas armas auxilia o desenvolvimento da força, da postura e da coordenação. Além disso, o aprendizado das técnicas envolvendo o jo e o boken auxilia o aprimoramento de outras técnicas de mãos vazias como ocorre no shihonage, em que todos os movimentos do nage são executados como se ele estivesse manejando um boken. Ao movimentar estas armas, o praticante deve utilizar primordialmente o movimento do quadril como se transferisse a energia do hara para a ponta da espada e do bastão. Nestes casos, a arma e aquele que a manipula se fundem formando um corpo só, funcionando o bastão ou a espada como uma extensão do corpo de quem os manipula.

Imagens 32 e 33: uso do bastão
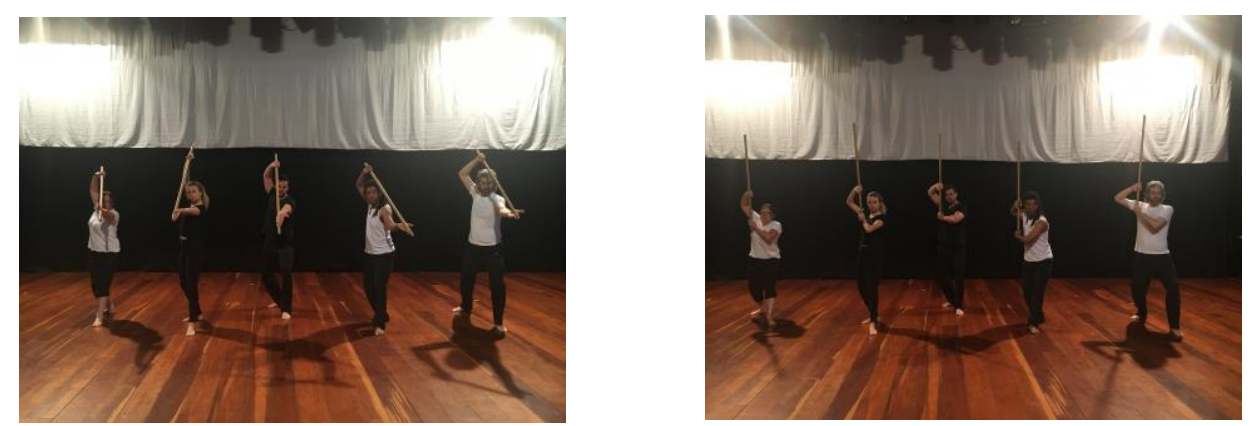

Fontes: arquivo do autor. 
9. Ukemi. Quedas. As três quedas do "aikido" são mae kaiten ukemi, ushiro kaiten ukemi e ushiro hanten ukemi. No "aikido" um dos princípios mais importantes é levantar depois de cair, pois ao longo da vida a queda é inevitável. Portanto, deve-se ter forças para levantar depois de uma derrocada. Pela queda, além de se desenvolver habilidades físicas importantes, se treina a resiliência, a determinação e a humildade. O fundador sempre pregava que não existe sucesso sem falha, pois é ela que nos prepara para os acertos. A queda é também uma defesa, pois, sabendo cair, além de se evitar lesões, a subida é sempre rápida e ágil. Além disso, deve-se ressaltar outro ponto: como as posições durante um treino se alteram constantemente, todos os aikidoistas passam pela estabilidade do nage e pelas quedas do uke. Esta dinâmica do "aikido" compõe com um importante provérbio japonês que diz: "Cair sete vezes, e levantar-se oito" (Nanakorobi yaoki). Percebe-se, dessa forma que, o "cair e levantar" do "aikido" não está relacionado somente à parte corporal de um treino, mas se conecta também à forma de $\hat{O}$-Sensei perceber a vida. De acordo com sua filosofia, cair ao longo da vida é inevitável. O importante é termos força para levantar e seguir em frente.

Imagem 34: ushiro hanten ukemi

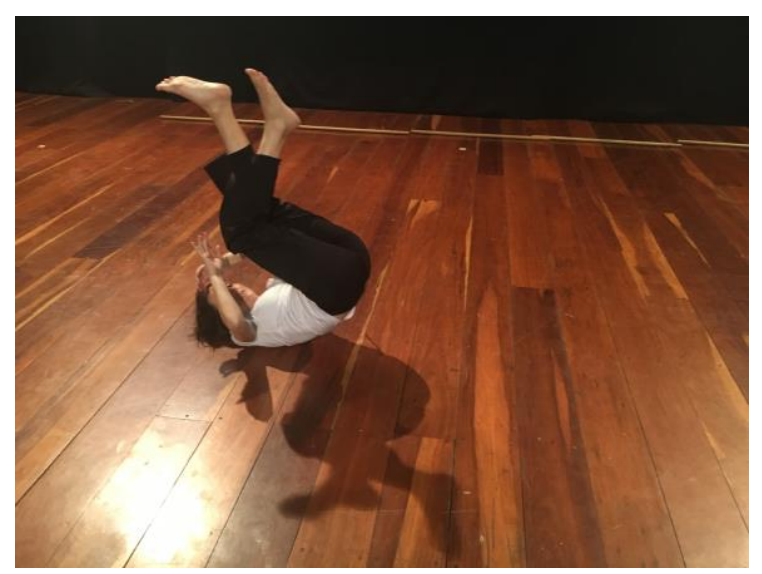

Fonte: arquivo do autor.

10. Reigi. Respeito à tradição e à etiqueta. Durante um treino deve-se seguir as regras de etiqueta, pois nestas regras estão incorporadas a tradição, a forma de perceber o mundo e de se relacionar com o que está a volta, a filosofia e a contextualização histórica que deu origem ao “aikido". Estas 
regras são balizas desta arte marcial para que suas raízes se mantenham e não se enfraqueçam.

Todos esses fundamentos são bases para que o "aikido" se mantenha e não se perca com o passar do tempo e que seja reconhecido como tal. Isto porque, apesar de existirem técnicas definidas e catalogadas, são infinitas as possibilidades de variações e de formas de execução, pois não existe uma única maneira correta de se fazer "aikido", sendo as combinações entre as técnicas infinitas e as derivações ilimitadas. Durante sua trajetória até os dias de hoje, o "aikido" vem sofrendo transformações, podendo ser identificadas diferenças, inclusive de grupo para grupo, dentro de uma mesma cidade. A respeito disto, Ô-Sensei costumava afirmar que "não há formas nem padrões no “aikido". Os movimentos naturais são os movimentos do "aikido". Sua profundidade é insondável e inesgotável” (UESHIBA, 2007, p. 114). Complementando essa ideia convém citar um ditado japonês que diz que "depois de entrar pela forma, deve sair da forma", ou seja, depois de aprender os fundamentos de determinada atividade, deve-se ter a liberdade de desenvolver sua maneira própria e pessoal de executá-la. Estas duas citações se complementam, e representam o que se pretende com o "aikido". Pelo exposto, entende-se que, diante de todas essas variáveis à que essa arte marcial está sujeita, se houver o devido respeito aos fundamentos, o "aikido" se fará respeitado.

Deve-se acrescentar ainda, que todos os fundamentos apresentados refletem o que é natural, na medida em que se respeita o formato natural do corpo, suas particularidades, estrutura e direção natural. Assim, respeitando-se os limites de cada corpo, as técnicas dessa arte marcial não pretendem agredir ou lesionar, mas ao contrário, objetivam desenvolver a flexibilidade, a coordenação, a escuta de um para outro, a conexão com o parceiro, a pessoalidade durante a prática, dentre outras coisas. Como exemplo, podemos citar as torções; todas seguem a direção natural do corpo. Da mesma forma o movimento em espiral, segue a dinâmica da vida, apresentado desde o movimento do universo até a forma do DNA do ser humano. Assim, respeitando-se o que é natural, estará sendo praticado o "aikido".

É importante deixar enfatizado também que, apesar da mencionada liberdade em relação à forma, incentivada pelo próprio $\operatorname{Doshu}$, o respeito a ela quando se começa a praticar é muito importante, pois, é aprendendo-a e aprimorando-a que se terá consciência do que o fundador quis dizer com "movimentos naturais". Somente pela prática atenta e disciplinada que se chegará a uma boa autoconscientização corporal. A esse respeito Morihei Ueshiba ensinava que o aikidoista nunca deve se considerar um 
mestre que já sabe tudo. Ele precisa continuar treinando diariamente para, junto com seus parceiros e alunos, avançar no caminho da harmonia (UESHIBA apud STEVENS, 2007, p. 143). Assim, a persistência na prática são as chaves para um bom desenvolvimento pessoal e técnico.

Nesse ponto podemos perceber uma semelhança entre "aikido" e "capoeira", uma vez que para ambos o respeito à individualidade e às possibilidades corporais de cada um é essencial. Em ambas as artes a preocupação técnica não pode levar a uma uniformização e mecanização dos movimentos, inibindo a expressividade pessoal e criativa. Por outro lado, as bases fundamentais devem ser respeitadas de modo que a liberdade expressiva do praticante não desconfigure ou deturpe a arte marcial. Tendo em vista, portanto, a importância desses fundamentos, todos eles serviram como base para a elaboração de exercícios e procedimentos para o trabalho com o ator visando sua autoconscientização, estimulação criativa e ampliação de repertório.

\subsubsection{Sonoridade}

No Japão existe uma variedade grande de tipos de músicas como o gagaku, um tipo de música clássica que foi executada pela corte e o honkyoku executado pelos monges para aproximar-se da iluminação. As atividades musicais também eram práticas importantes entre os samurais, eram consideradas formas de adquirir conhecimento. Outras artes como o No e o Kabubi também lançavam mão de peças musicais e números de dança para completar a dramaturgia. As gueixas são figuras também muito importantes no Japão e se dedicam ao estudo das artes, dentre elas o canto e o instrumento e tem a função de entreter. Percebe-se, portanto, que a cultura japonesa é permeada por muitos tipos de músicas e danças que variam de acordo com cada classe social.

Sonoramente, o treino de "aikido" não recorre a nenhum tipo de música, porém pratica-se o kiai que é um som efetuado pelo aikidoista no momento de finalizar uma técnica, especialmente com armas, pressionando a musculatura do abdômen durante a expiração. É uma explosão de energia que é externalizada pela voz. Considerando que, de acordo com o pensamento oriental, pela respiração nos conectamos com o universo, nosso kiai é uma forma de nos apresentar como fruto desta conexão. Neste sentido, o fundador reforçava a importância do Aun no Kokyu. Aun é o som equivalente ao Om indiano. Aun, portanto, é o mantra supremo para a cultura japonesa. Aun no Kokyu seria, 
portanto, a inspiração de toda a energia do universo e pelo som se conectar com esse sistema. Como o AUN todo kiai é um tipo de kotomana. Kototama significa "espírito da palavra" e emprega uma variedade de sons e melodias que são entoados a fim de buscar a purificação e a energização do corpo.

O kototama utiliza todas as vogais, sendo que cada uma delas procura acessar algo específico no corpo - A, O, U, E, I (STEVENS, 2001). Segundo Stevens, 2001, o kototama é emitido dos chacras que no "aikido" são cabeça, garganta, coração e umbigo. $\mathrm{O}$ da cabeça está relacionado à percepção, da garganta à calma, do coração aos sentimentos de amor e o umbigo à fonte da energia vital, hara. $\mathrm{O}$ som $\mathrm{A}$ é ativado na garganta e simboliza o início de todas as coisas, o U representa o som da criação e é ativado na barriga, o som E serve para vivificar os membros e o I representa a respiração vital, que se irradia por cada poro. O kototama tem, assim, como objetivo reenergizar e curar o corpo. Outro aspecto importante do kototama é a ênfase no poder das palavras que pode ser tanto uma arma ou ferramenta para a promoção da violência como da paz e gentileza. Para Stevens, o maior kototama é a risada, pois ela anima e dá prazer tanto a quem ri como a quem ouve.

Os elementos sonoros aqui descritos foram utilizados no trabalho com os atores, principalmente para ativar estados emocionais diferentes, trazendo nuanças tanto para a voz como para o movimento. Por consequência, especialmente o kototama e o kiai, foram aproveitados para a criação da dramaturgia. 


\section{Capítulo V - O treinamento como caminho para preparação do ator e criação tendo como base elementos do "aikido" e da "capoeira"}

Nesta pesquisa, quando falamos em preparação, nos referimos a todos os procedimentos práticos realizados pelos atores visando o aprimoramento psicofísico. $\mathrm{O}$ ator, para estar pronto para o trabalho cênico, necessita de uma preparação que amplie sua conscientização corporal, que desenvolva habilidades e que enriqueça seu repertório técnico e artístico, ampliando suas possibilidades de criação. Durante esta preparação, adotamos como primeira etapa de trabalho o treinamento. E o que vem a ser ele neste trabalho?

Quando ouvimos o termo "treinamento" nos remetemos às práticas que visam preparar determinada pessoa para uma função específica. $\mathrm{O}$ treinamento pressupõe o aprendizado de uma técnica visando à execução de uma atividade com maior destreza, aptidão, capacidade. Embora seja comum nos deparar com este termo nas práticas esportivas, em que o esporte demanda um forte preparo físico e mental, é importante destacar que é utilizado para além desta área, em outros tipos de atividades, como por exemplo nas artes cênicas.

Diversos pesquisadores do teatro já discorreram a respeito desse tema. Eugênio Barba, 1995, dispõe acerca da transposição do estado cotidiano para o cênico por meio do aprendizado de técnicas que trabalhem o equilíbrio, a oposição dos impulsos e a energia envolvida na realização de um movimento. Jerzy Grotowski, 1992, em suas investigações, dispõe a respeito do estabelecimento de "certos estados de ser" cujo paralelo com o estado do ator é evidente. Constantin Stanislavski, 1990, foi o primeiro a se preocupar com a criação de um sistema de trabalho específico para o ator, desenvolvendo o método das ações físicas. Muito anteriormente a todos eles, Zeami, 1966, em seu livro Fushikaden, ao desenvolver o conceito da flor para o teatro configura-se como uma qualidade inusitada e cativante encontrada no trabalho de um ator que, portanto, atrai a plateia e aponta que, para que o ator desenvolva esta flor, necessita de exercícios para polir sua arte. Estes procedimentos destinados a preparar o ator são, segundo Zeami, formas de se conhecer e de conhecer o outro. Assim como eles, vários outros pesquisadores de teatro vêm investigando este assunto na prática e elaborando treinamentos com o fim de aprofundar e aprimorar o trabalho do ator em cena. 
Esta pesquisa assemelha-se com diversos outros trabalhos desenvolvidos, porém, aqui entendemos que o treinamento não deva seguir um viés meramente tecnicista, mas ter como função principal a potencialização do trabalho criativo e expressivo.

Acerca do treinamento e do aprendizado de técnicas para o aprofundamento do trabalho do ator, Burnier defende que:

\begin{abstract}
A técnica do ator não deve ser apenas físico-mecânica, como de um halterofilista, mas humana, em vida, ou seja, algo que permita estabelecer um elo-comunicativo entre o humano em sua pessoa e o que seu corpo é e faz e, ao articular esse processo, projetá-lo, comunicando-o para seus expectadores. A técnica do ator, portanto, só existe, a nosso ver, na medida em que abre caminhos para um universo eminentemente humano e vivo, tanto para o ator quanto para o expectador. Do contrário ela seria apenas ginástica a preparar o corpo para uma atividade puramente física, na qual os aspectos humanos e subjetivos estariam resguardados ou adormecidos. (BURNIER, 2001, p. 25)
\end{abstract}

Portanto, neste trabalho, ao submeter o ator a um treinamento utilizamos procedimentos que preparassem o corpo como um todo, deixando-o disponível para um trabalho cênico específico, desenvolvendo novas habilidades, contribuindo para a ampliação de repertório e estimulando a criatividade. A ampliação de repertório ocupou uma posição importante no treinamento, em que possibilitou aos atores entrarem em contato com experiências diferentes e desafios novos.

Vimos que o corpo, em sua concepção, não é uma máquina ou um instrumento que vem montado, pronto e acabado, mas sim um todo vivo e dinâmico que se transforma ininterruptamente. O corpo vai ao longo de sua vivência aprendendo coisas de acordo com o contexto sociocultural em que vive. Cada cultura tem suas próprias técnicas, hábitos, formas de viver. Portanto, aprender estes elementos faz parte do processo natural de aprendizado. E neste processo de transformação e aprendizado encontra novas possibilidades, ultrapassa limites, desenvolve habilidades, traça novos caminhos e se descobre mais a cada dia.

A respeito desse tema, Noe, 2010, ao abordar a plasticidade da consciência, explica que as adaptações e transformações que o ser humano sofre diante da rotina ou da falta dela tem fundamental importância em sua vida, afetando sua formação. Noe expõe que na vida existem dois aspectos presentes: de um lado a rotina, hábito e repetição; e de outro a surpresa, novidade e quebra de rotina. Seguindo esta ideia Noe, defende que o homem é um ser de hábitos, e os cria como forma de conseguir uma estabilidade, criar laços, deixar rastros, aprofundar conhecimentos, aprimorar 
habilidades, enfim, ser parte de sua comunidade e sua comunidade fazer parte dele. Este filósofo explica que o contexto ambiental em que crescemos e estabelecemos nossas primeiras relações, pelo tempo em que somos expostos, ainda que venhamos a nos separar dele, será sempre parte de nós em alguma medida. Acrescente-se ainda que a rotina nos ajuda a adquirir virtuosismo naquilo que decidimos nos dedicar. Sem a repetição e a persistência em uma mesma atividade, não adquirimos expertise. Continua explicando que, quando estamos aprendendo uma nova atividade, prestamos muita atenção em nós mesmos e especialmente no mecanismo do que estamos fazendo. Ao contrário, quando temos domínio sobre a atividade, voltamos nossa atenção para o todo, para as táticas e estabelecemos outros focos que não são acessíveis para aquele que está no estágio inicial. Acerca disso Noe argumenta que:

A neurociência já confirmou que iniciantes e experts têm maneiras qualitativamente diferentes de se envolver com o que estão fazendo. Foi demonstrado, por exemplo, que experts altamente treinados músicos, atletas, etc.- mostram, de um modo geral, uma diminuição do envolvimento da ativação do cérebro quando estão engajados nas performances de suas habilidades, em comparação com os iniciantes (...) O sistema físico apresentado pelo expert mostra economia e elegância. ${ }^{25}$ (NOE, 2009, p. 100)

A expertise tem relação com a fluidez, considerada a partir da noção trazida pelo psicólogo Mihaly Csiksgentmihalyi, 1975, que desenvolveu suas investigações analisando diferentes experiências ligadas ao esporte, dança e o ato de jogar. Este psicólogo detectou que os jogadores mais experientes se colocam no jogo de forma que a consciência do mundo exterior desaparece e se funde com o que está fazendo. A este fenômeno ele chama de fluidez, segundo ele, este estado seria algo próximo ao estado de transe. A fluidez poderia ser entendida, portanto, como a sensação de perder-se na ação, desaparecendo qualquer preocupação com outras coisas que não seja a própria ação que se está realizando. Trata-se de um estado dinâmico sentido pelas pessoas que se engajam de forma total naquilo que está fazendo. Csikszentmihalyi ao tratar da fluidez expõe que:

25. "That novices and experts have qualitatively different manners of involvement with what they are doing has also been confirmed by neuroscience. It has been shown, for example, that highly trained experts - musicians, athletes, etc.- show a decrease in the overall level of brain activation when they are engaged in the performance of their skills compared to beginners... The physical systems drawn into play by the experts show economy and elegance.” (NOE, 2009, p. 100) 
No estado de fluidez, ação segue ação de acordo com a lógica interna que parece não precisar da intervenção consciente do ator. Ele experencia isto como uma unidade que flui de um momento para o seguinte, no qual ele tem o total controle de suas ações, e no qual há pouca distinção entre o eu e o ambiente, entre o estímulo e a resposta, ou entre passado, presente e futuro (...). ${ }^{26}$ (CSIKSZENTMIHALYI, 1975, p. 36)

Em um dos casos estudados pelo psicólogo, um bailarino, para explicar esta sensação de fluidez que sentia ao dançar afirmou: "a dança me dançava". (Cskszentmihalyi, 1975). Ou seja, ao mesmo tempo em que o expert tem total consciência de si mesmo e do que está fazendo na atividade escolhida, não há uma preocupação em relação ao que se deve realizar, mas apenas um estado de tranquilidade e de foco, como se o corpo estivesse se movimentando por si só.

Noe, 2010, ao tratar desse assunto, explica que os praticantes experientes, ao contrário dos iniciantes, prejudicam a qualidade de suas performances quando colocam o foco no mecanismo da atividade. A expertise faz com que o praticante da atividade direcione sua atenção para o conjunto do que está sendo executado e não para um ponto específico. Quando o expert se preocupa apenas com o mecanismo do que está executando, ele interrompe este estado de fluidez (NOE, 2010). Reforçando este tema, Csikszentmihalyi explica que:

Talvez o sinal mais claro de fluidez seja a fusão entre a consciência e a ação. A pessoa em fluidez não tem uma perspectiva dualista: ela tem consciência de suas ações, mas não consciência por si só. Um jogador de tênis não divide a atenção entre a bola e o oponente, um jogador de xadrez foca na estratégia do jogo. (...) Quando a consciência se divide, que é o momento em que o jogador percebe a atividade de fora, a fluidez é interrompida. ${ }^{27}$ (CSIKSZENTMIHALYI 1975, p. 38)

26. "In the flow state, action follows upon action according to an internal logic that seems to need no conscious intervention by the actor. He experiences it as a unified flowing from one moment to the next, in which he is in control of his actions, and in which there is little distinction between self and environment, between stimulus and response, or between past, present, and future".

27. "Perhaps the clearest sign of flow is the merging of the action and and awareness. A person in flow has no dualistic perspective: he is aware of his actions but not of the awareness itself. A tennis player pays undivided attention to the ball and the oponente, chess master focuses on the strategy of the game ... When awareness becomes split, so that one perceives the activity from "outside," flow is interrupted." (p. 38) 
Entretanto, este psicólogo lembra que a fluidez dificilmente será mantida por um período longo de tempo sem que aconteçam momentâneas interrupções. Normalmente uma pessoa consegue manter a fusão da consciência e de suas ações apenas por um período curto de tempo. Estas interrupções acontecem quando ela deixa de vivenciar o todo e passa a ter uma perspectiva de fora, permitindo pensamentos como: "Será que estou fazendo corretamente?", ou "Estou indo bem?". Portanto, é importante que a pessoa se envolva a maior parte possível do tempo com o conjunto da atividade que estiver realizando, evitando atenções divididas, pensamentos de autocrítica e julgamentos sobre sua própria performance. A fluidez se conecta com o "se deixar levar" pela atividade que estiver realizando. Neste estado, esta pessoa não se vê separado da atividade e seu corpo está totalmente acordado, com a energia fluindo intensamente, de modo que ela se sinta confortável, relaxada e energética (Csikszentmihalyi, 1975).

Como já se destacou anteriormente, este estado de fluidez é essencial tanto para o "aikido" como para a "capoeira", pois o praticante, seja de uma arte seja de outra, não pode perder sua atenção com dificuldades técnicas ou com preocupações com o que fará na sequência. O que deverá fazer e como se relacionará com o entorno, fluirá naturalmente. $\mathrm{O}$ estímulo e a reação, quase se misturam e o pensamento flui com o corpo todo a partir da relação entre os parceiros. Obviamente este estado só é alcançado com um tempo longo de treino e com disciplina, quando o praticante deixa de se preocupar com questões básicas e passa a focar no todo da atividade.

Este estado fluido também pode ser observado no trabalho do ator. Quanto mais tempo dedicado à determinada prática, mais virtuosismo, segurança e conforto ele adquire dentro dessa área, podendo arriscar, expandir seus limites e produzir materiais artísticos, tanto criativa e tecnicamente mais aprimorados.

Temos, portanto, que a repetição, a rotina e o hábito são formas de se chegar à excelência e de deixar nossas impressões e rastros por onde passamos. Por este ponto de vista ter hábito e rotina é positivo.

Por outro lado, Noe, 2009, defende que viver dia após dia seguindo hábitos, sem se impor novidades e surpresas, pode nos aproximar da velhice. Os dias de uma vida com base em rotina são, via de regra, iguais, demandando assim pouco gasto de energia, pois já se sabe o que esperar. A partir disto, Noe (2009, p.51) expõe que: "mudanças 
forçam você a se renovar por meio do desenvolvimento de novas relações, novos hábitos, novas formas de se relacionar com o mundo em volta de você" 28 . O filósofo segue expondo que quando a rotina é interrompida, a vida adquire um tom especial. Dessa forma, envelhecer é abrir mão das surpresas e permanecer jovem é mantê-las sempre presente.

Temos, assim, por todo o exposto, que ter hábitos e rotina é importante para o ser humano se aprimorar gradualmente, mas quebrá-los de tempos em tempos com novidades traz um novo frescor para a vida.

Ainda acerca da aquisição de novos conhecimentos, Katz, 2005, explica que a cada movimento que fazemos, a cada informação que percebemos, é como se um mapa, metaforicamente falando, fosse sendo desenhado no cérebro, registrando os caminhos pelos quais passaram os movimentos, e que afetará o raciocínio corporal. Um treino de arte marcial, por exemplo, originará um mapa diferente de um treino de balé, uma vez que o corpo é movimentado de formas diferentes. Consequentemente, quanto mais nos colocamos em práticas novas, mais esse mapa vai se expandindo, ampliando, assim as possibilidades de ação e de pensamento com o corpo.

Dessa forma, pensando no trabalho do ator, um treinamento específico pode ajudá-lo tanto a experimentar a novidade e a aquisição de conhecimentos novos como a rotina e o aprofundamento do que foi aprendido. Este tipo de abordagem prática pode conduzir o ator a uma autonomia de atuação e criativa e uma potencialização expressiva, na medida em que ele terá mais recursos a seu alcance para fisicalizar suas ideias, inquietações, prazeres, questionamentos, enfim, tudo aquilo que o move como artista.

Além disso, de acordo com Damásio (2013, p. 407), o cérebro é um sistema criativo e, portanto, quando constrói esse mapa, o faz utilizando "seus próprios parâmetros e sua própria estrutura interna, criando assim, um mundo único (...)”. Em outras palavras podemos dizer que esse processo não se dá de forma homogênea e uniforme, uma vez que cada pessoa se apropriará das informações, construindo esse mapa a seu modo, de acordo com suas próprias características. Temos, portanto, que o treinamento, ainda que seja igual para um grupo de atores, será aproveitado de forma

28. “(...) changes force you to renew yourself by developing anew in relation to new external structures, new habits, new modes of involvement with the world around you." (NOE, 2009, p. 51) 
única e particular para cada um. Por essa razão é equivocado o entendimento de que o treinamento leva a uma uniformização da prática.

A respeito da pessoalidade aliada à técnica, Silva, 2008, tendo como referência sua experiência com a "capoeira”, explica que:

O processo de aprendizagem é individual (...) A preparação para a capoeira e o desenvolvimento do repertório pessoal expressivo do estudante requerem a aquisição de uma habilidade motora específica, para que possa expressar seus afetos com liberdade através da linguagem da capoeira. (SILVA, 2008, p. 23)

Silva defende, portanto, que a aquisição de uma habilidade específica e a expressividade pessoal devem caminhar juntas no processo de aprendizagem, dando margem, por consequência, ao surgimento de tantas capoeiras quanto o número de praticantes.

Silva segue explicando que "cada um tem sua própria ginga, ou melhor, sua própria capoeira, como uma impressão digital” (SILVA, 2010, p. 42). Esta subjetividade no ato de jogar é muito importante nesta arte, pois de outra forma ficaria empobrecida e meramente tecnicista. Quando vemos, por exemplo, dois capoeiristas jogando numa roda ao som de uma música que os estimula, percebemos dois seres em conexão, porém realizando movimentos com características pessoais, ficando evidente a forma particular de cada um de se relacionar com as técnicas aprendidas.

O que foi exposto acima por Silva a respeito da "capoeira", se ajusta perfeitamente à filosofia do "aikido" segundo a qual não existe uma única forma de se realizar as técnicas catalogadas por esta arte marcial. O processo de aprendizagem e a forma de execução são pessoais e se moldam às necessidades e às potencialidades de cada praticante.

Estabelecendo o paralelo com o trabalho do ator, podemos tomar emprestado o termo "impressão digital" usado pelo prof. dr. Armando Sérgio da Silva em seu trabalho de livre docência A Oficina da Essência em que o define como um processo de assimilação dos estímulos pelo corpo de maneira pessoal, única e intransferível. Tratase de “uma espécie de 'dicionário' de 'potencialidades expressivas' personalíssimas, que nascem de reações sintomáticas a estímulos físicos (...)" (SILVA, 2010, p. 78). Este conceito se refere, portanto, à maneira como os estímulos são usados pelos atores durante um processo de experimentação e de criação e em como estes estímulos 
reverberam no corpo de cada um, resultando, assim, em expressividades muito particulares.

Convém lembrar, entretanto, que, se por um lado o treinamento tem muitos aspectos subjetivos, tendo em vista que depende da forma de apropriação individual das informações propostas, por outro lado ele dá um direcionamento estético para o trabalho artístico, influenciando sobremaneira o que será realizado daí em diante. Corroborando esta ideia, Katz (2005, p. 166) expõe que "treinar significa construir mapas corticais. Assim, deve-se conectar o mais estritamente possível a ambição estética de um corpo a sua ação de treinamento técnico". Buscou-se, dessa forma, nesta investigação, uma ligação direta entre o treinamento e a criação de modo que ambos integrassem um mesmo processo. Como resultado disso pretendemos, por meio do fenômeno da corporeidade, chegar a uma corporalidade específica.

Outro aspecto que merece ser reforçado a respeito do treinamento é o fato de que o treinamento potencializa as qualidades do sujeito e o ajuda a romper barreiras, ampliando suas possibilidades. Portanto, não se pretende transformar o corpo do ator em algo que ele não é, mas, ao contrário, busca-se provocar e estimular mudanças de modo que o sujeito não fique anulado e sinta-se mais estimulado e bem preparado para as necessidades da cena. A esse respeito Romano (2013, p. 180) argumenta que "a partir do treinamento corporal, acontece a transição do corpo 'comum' para um corpo 'diferenciado' no mesmo sujeito". Temos, assim, que o sujeito, com o treinamento, descobre-se mais a cada dia e, respeitando as particularidades de seu corpo, avança gradualmente técnica e artisticamente.

Barba, ao tratar desse processo de transformação constante, assinala que:

O treinamento não é uma forma de ascetismo pessoal, uma dureza hostil em relação a si mesmo, uma perseguição do corpo. $\mathrm{O}$ treinamento é um teste que coloca a prova as próprias intenções, até onde se está disposto a empenhar toda a própria pessoa naquilo em que se acredita e que se afirma, a possibilidade em superar o divórcio entre a intenção e a realização. (BARBA, 1991, p. 59)

Barba, neste trecho, toca em um assunto que diz respeito tanto a atores profissionais quanto a estudantes de teatro: o foco e o aprofundamento naquilo que se propõe, possibilitando que a intenção seja compatível com o que é executado. Assim, manter-se disciplinado e concentrado em determinado objetivo é uma das chaves para o aprofundamento do trabalho. Outra questão que identifico a partir disso é que percebo nos atores uma certa angústia e insegurança em relação à dificuldade de trazer para o 
corpo todo, de forma artística, o que está internamente a ele. Acredito que o artista é movido por suas dores, inquietações, prazeres. E externalizar isso poeticamente com todo o conjunto psicofísico tende a ser um desafio, algumas vezes. Diante desse ponto, objetivamos, portanto, com o treinamento nesta pesquisa, munir os atores de mais recursos e condições para que eles se sentissem aptos a colocar em seus movimentos e nas relações que estabelecessem tudo aquilo que os motivavam e despertavam neles o desejo de criar.

Por fim, o treinamento tem como grande importância auxiliar o autoconhecimento, uma vez que o ator se depara com suas limitações e potencialidades e pode desenvolver seu trabalho se apoiando em bases mais claras. Seguindo esse raciocínio, podemos citar Zeami, 1968, quando ele defende que o ator quando conhece o nível em que está, a flor correspondente a esse nível não mais desaparecerá. Em outras palavras, podemos dizer que, quando o ator tem consciência do que conseguiu conquistar em seu trabalho e do que ainda precisa desenvolver, ele consegue aprimorar o que já tem e avançar com mais rapidez rumo ao que ainda não foi atingido. Ter um bom conhecimento sobre si mesmo é essencial para o ator desenvolver um bom trabalho em cena.

A partir das concepções expostas acima, nos preocupamos no treinamento em não utilizar formas e fórmulas prontas para a prática, mas ir construindo uma estrutura de acordo com as necessidades de cada momento e de cada ator, pois de outra forma, estaríamos apenas reproduzindo receitas que funcionaram para um grupo em algum momento, mas que talvez não se ajustassem ao nosso.

Agora, porém, quando nos deparamos com o "aikido" e com a "capoeira" percebemos um entrelaçamento entre o treinamento para a arte e para o esporte, uma vez que ambas têm tanto qualidades esportivas quanto artísticas. Como em toda arte marcial, o ato de treinar, visa à melhora do condicionamento físico, da coordenação motora, da autoconscientização corporal, da prontidão e da flexibilidade, permitindo a superação dos próprios limites na medida em que o corpo vai se fortalecendo e se ajustando aos movimentos que lhes são propostos. Entretanto, estas duas artes marciais proporcionam também o contato com elementos artísticos que tem como uma das principais características o envolvimento corporal de forma expressiva, fornecendo, assim, material rico para a criação de uma dramaturgia do ator. Portanto, pretendemos elaborar um treinamento que reunisse características tanto de aspectos esportivos como 
artísticos destas duas artes marciais e que fossem pertinentes para o trabalho do ator, visando um aprimoramento do corpo como um todo.

Seguindo este pensamento, foram iniciados os trabalhos práticos com alguns atores que em sua maioria não tinham formação nas artes marciais pesquisadas, possuíam pouca experiência na cena teatral, não tinham um preparo corporal aprofundado, nem disponibilidade para se dedicar a este trabalho além dos horários reservados para o ensaio. Ou seja, eram atores iniciantes, com exceção de Jefferson Mathias, e com tempo exíguo para esta pesquisa. Este, portanto, foi nosso ponto de partida: como fazer com que os elementos extraídos do "aikido" e da "capoeira" auxiliassem o trabalho cênico desses atores com estas características.

Começamos a investigação prática com o ator Wagner Cerqueira e as atrizes Nathalia Amadei, Carolina de Brito e Larissa Hupallo. O trabalho com estes dois núcleos foi importante, pois pudemos perceber na prática quais poderiam ser os melhores encaminhamentos a serem adotados e, assim, deixar os procedimentos mais claros e o direcionamento do trabalho mais eficiente. Os dois grupos se desfizeram ao final de um ano e o trabalho com outro grupo começou. Com este último, composto pelos atores Murilo Rocha, Helena Semedo, Isabella Leonel, Ignacio Muñoz e Jefferson Mathias, também capoeirista, trabalhamos o texto Hamlet, que deu origem a última demonstração cênica desta pesquisa. Tendo em vista que todos contribuíram sobremaneira para o andamento e organização da pesquisa, serão apresentadas aqui partes dos três processos vivenciados.

A partir das necessidades do coletivo, foi elaborado um treinamento que teve os seguintes focos: a) preparo corporal básico como autoconscientização, alongamento, reorganização postural, coordenação motora e condicionamento físico; b) introdução a repertório novo; c) fluidez, precisão e limpeza; d) elaboração criativa e pessoal a partir do material praticado e d) conexão com os parceiros. Assim, o ensaio foi dividido em três partes:

Parte I: aquecimento que objetivasse o aprimoramento individual e coletivo com exercícios de alongamento, de condicionamento, de resistência, de respiração e de coordenação motora. Esta parte era definida tendo-se em vista o que se trabalharia naquele dia a fim de que este momento servisse de preparação efetiva e estímulo para o que viria na sequência. Portanto, optamos por não haver um aquecimento padrão que se repetiria em todos os ensaios. 
Parte II: aprendizado de repertório novo e experimentações corporais tendo como referências elementos selecionados a partir das artes marciais aqui estudadas, focando no aprimoramento da expressividade corporal, na conexão com o parceiro, no estímulo da criatividade, na superação de dificuldades físicas e na descoberta de novos caminhos artísticos por meio do corpo;

Estas duas etapas foram importantes para que, ao longo do processo, pudéssemos desenvolver a criação cênica. O trabalho focando a criação das cenas só foi acrescentada aos ensaios quando os atores já estavam mais à vontade com o universo pesquisado e se sentiram mais apropriados do material proposto durante os trabalhos práticos.

Parte III: na criação cênica os procedimentos utilizados foram elaborados e aplicados com aumento gradual de dificuldade, de modo que as necessidades de cada um fossem sendo atendidas. A pessoalidade, presente também nas práticas do "aikido" e da "capoeira", foi um dos motores desta pesquisa, em que foi respeitado tanto os limites de cada ator quanto a forma de cada um se relacionar com as referências que lhes foram apresentadas. Assim, respeitando-se as potencialidades de cada um, se pretendeu colocar à disposição elementos novos que possibilitassem novas formas de perceber, se relacionar com o mundo, de desenvolver novas habilidades e não uma simples repetição de movimentos codificados. Buscou-se, por consequência, tirá-los da zona de conforto, rompendo padrões, para possibilitar vivências novas, despertando novas sensações; ampliar o repertório poético, estimulando as criações; e potencializar a expressividade a partir de suas características pessoais.

Todas as referências utilizadas na parte prática deste trabalho extraídas do "aikido" e da "capoeira" serviram como "anteparos" que nortearam o trabalho do ator e apoiaram sua criação cênica. "Anteparo" é o termo utilizado por Silva, 2003, a partir da própria acepção do termo ${ }^{29}$ para designar os estímulos diversos utilizados pelos atores em seus processos criativos que o amparem neste percurso tais como música, textos, imagens, dentre outros. Temos, portanto, as referidas artes marciais nesta pesquisa não

29. Anteparo: “(...) designação genérica de peças (tabiques, biombos, guarda-ventos, etc.) que servem para resguardar ou proteger alguém ou alguma coisa. 3. Resguardo, proteção, defesa.” In: Dicionário Aurélio. 1 ed. Rio de Janeiro. Ed. Nova Fronteira. 1975. p. 104 
como meros materiais a serem reproduzidos pelo ator em cena, mas como referências que o ajudaram a alcançar um estado cênico, uma corporalidade específica e conseguir apoios que embasassem suas criações.

A fim de atender estes objetivos, e seguindo as ideias expostas acima, elegemos como procedimentos básicos para o trabalho prático a repetição e a improvisação. A separação em itens tem como função apenas deixar claros os procedimentos adotados, uma vez que os tópicos apresentados abaixo se deram de forma conjunta e não sequencial. A intercalação do trabalho individual e relacional, da repetição e criação aconteceu durante todo o processo de acordo com a necessidade de cada momento.

Segue abaixo uma exposição mais detalhada do que foi realizado na investigação prática.

\title{
5.1. Repetição como caminho para novas descobertas
}

Já vimos que a repetição ajuda a desenvolver habilidades, criando outros padrões corporais e fazendo com que novas referências passem a integrar o universo do ator. Mas convém esclarecer que a repetição não significa a realização de um mesmo movimento mais de uma vez da mesma forma. A cada vez que repetimos algo diferenças graduais vão emergindo, pois, o corpo vai se transformando na medida em que entra em contato com este algo. Acerca disso, Katz explica que:

\begin{abstract}
A habilidade que se repete melhora gradualmente através do treinamento que burila o exercício. No entanto, eventualmente, irrompem novas circuitações, que surpreendem o controle. Como se o corpo desenvolvesse uma solução inteligente não prevista pela consciência. Isso ocorre, muito provavelmente, porque um processo de repetição sem minúsculas diferenças em cada repetição. E a repetição com essas minúsculas diferenças, a certa altura, produz uma diferença que se nota. As várias qualidades de informação que um corpo produz e abriga não são compartimentadas e estanques, mas se comunicam e se relacionam. Assim, um processo de repetição, também está modificando todo o resto, que não está sendo especificamente repetido. (KATZ, 2005, p, 38-39)
\end{abstract}

Temos, portanto, que a repetição tem o condão de proporcionar a aprendizagem de uma nova habilidade, o autoaprimoramento em relação a este novo conhecimento e, por consequência, abrir as portas para novas experiências decorrentes desse processo. Em outras palavras podemos dizer que a repetição não se baseia em fazer da mesma forma um movimento seguidas vezes, mas vivenciar novas coisas a cada vez que o 
fazemos. A repetição, seguindo a noção de Alva Noe, 2009, estaria na esfera da criação de hábitos, da rotina, estabelecendo uma área de conforto no qual o ator se sente mais livre para colocar em prática o que foi aprendido, avançando gradualmente a cada dia.

Seguindo este pensamento, foi proposto nesta fase que os atores tivessem um contato breve com algumas técnicas do "aikido" e da "capoeira", a fim de que pudessem experimentar em seus próprios corpos movimentos com qualidades e habilidades inerentes a estas artes marciais. $\mathrm{O}$ foco neste caso foi o estudo do corpo e movimento a partir das técnicas selecionadas.

Seguindo esta proposta, no início de toda prática realizávamos um aquecimento composto por alongamentos e exercícios com o objetivo de preparar os corpos dos atores deixando-os mais disponíveis e acessíveis para a realização das técnicas. Em relação ao "aikido" o aquecimento era composto por alongamentos e exercícios de respiração aprendidos por mim em alguns treinos regulares de "aikido" no Cremona Dojo, em visitas a outros dojos e em workshops ao longo de toda a pesquisa. Então, por exemplo, quando no aquecimento realizávamos um alongamento sobre as articulações, tornava mais fácil a execução de torções como kotegaeshi e sankyo. Os exercícios de respiração, por sua vez, auxiliavam os atores na prática dos movimentos com jo. Seguimos a mesma linha com a "capoeira" submetendo os atores a um aquecimento que foi gradualmente trazendo para o corpo o dinamismo da "capoeira". Neste caso, realizávamos exercícios para fortalecer a musculatura, principalmente braços, abdômen e pernas, desenvolver a flexibilidade das articulações e movimentar o corpo como um todo buscando agilidade. A ginga e as derivações que fomos criando durante os ensaios tiveram um papel importante nesse momento, pois, ajudou os atores a ganharem resistência física, a terem mais molejo e leveza na movimentação e a desenvolverem a coordenação motora. Tanto o aquecimento a partir do "aikido" como da "capoeira" tinham o mesmo objetivo que era preparar o corpo em sua integralidade para tornar mais eficiente a apropriação do repertório novo. Entretanto, cada um deles trazia especificidades na medida em que estavam preparando o corpo para tipos diferentes de movimentos. Consequentemente, o aquecimento para cada ensaio era planejado de acordo com o que faríamos naquele dia. Assim, procurou-se durante todo o processo conectar os procedimentos desde a preparação até a criação, de modo que todos os exercícios propostos fossem importantes em todas as fases da pesquisa. Objetivamos, dessa forma, construir um percurso de maneira que o resultado cênico fosse efetivamente alimentado durante toda a prática. 
Tomando como referência o último grupo formado, com quem utilizamos o texto Hamlet, quando já tínhamos experimentado algumas possibilidades de abordagem prática das artes marciais, decidimos começar o processo separando uma quantidade de ensaios para o "aikido" e outra para a "capoeira”. Evitamos, a princípio, experimentálos no mesmo dia, pois percebi que tudo se misturava e, como consequência, os atores tinham dificuldade de organizar corporalmente as informações novas, o que dificultava as experimentações que viriam na sequência. Com o foco mais definido em cada ensaio os atores foram se familiarizando ao repertório novo. Apenas com o avanço da prática começamos a recorrer a elementos do "aikido" e da "capoeira" no mesmo ensaio a fim de que começássemos a investigar uma possível intersecção entre as duas artes.

A escolha das técnicas para se trabalhar nesse momento seguiu os seguintes critérios: grau de dificuldade, adequação às necessidades dos atores, envolvimento do corpo e presença clara de características fundamentais destas artes. Assim, pensando na "capoeira", foram, em um primeiro momento, selecionadas a ginga, a cocorinha, a negativa, a vingativa e a benção, por serem por nós consideradas técnicas que poderiam proporcionar qualidades de movimentos diferentes e que resumem várias características importantes da "capoeira". A ginga traz a base do molejo na movimentação, a benção introduz movimento com as pernas e de ataque, a cocorinha e a negativa utilizam o nível baixo em contraposição aos demais que são altos, além de introduzir o ator à ideia da esquiva, e a vingativa proporciona o contato corporal que não identificamos tão fortemente nas anteriores. Como recurso para auxiliar as experimentações, utilizamos músicas do universo da "capoeira", desde as que são executadas em rodas até as presentes no repertório brasileiro inspiradas na "capoeira".

Os mesmos procedimentos para estimular os atores seguiram-se com o "aikido". À semelhança do que foi realizado com a "capoeira", foram selecionadas músicas tradicionais da cultura japonesa a fim de proporcionar diferentes sensações. Em relação às técnicas, neste caso, foram inicialmente selecionadas as seguintes: Kamae, tenkan, irimi tenkan, shiko, katatetori daiti kyo ura, katatetori shihonage e tenti nage. Estas técnicas, a nosso ver, possibilitariam de forma clara a compreensão dos princípios do "aikido" e ofereceriam material para uma experimentação em relação à qualidade do movimento. Assim, Kamae, tenkan, irimi tenkan e o shiko proporcionam a descoberta de uma nova forma de caminhar e de se relacionar com o espaço, seguindo as noções de relaxamento ativo e de esfericidade. As técnicas katatetori daiti kyo e katatetori shihonage permitem a prática da relação com o parceiro, o deslocamento nas quatro 
direções e a movimentação do corpo como um todo, tendo o koshi como centro forte e as extremidades conectadas a este centro. Por fim, o tenti nage, traz para os atores a ideia da conexão céu e terra, sendo seu corpo parte dessa conexão. Posteriormente inserimos as técnicas com bastão no treinamento, visando à conexão com a respiração, o uso do tônus, o kiai e a reorganização postural.

Tomando como paralelo a pintura, as técnicas aprendidas e os princípios experimentados corporalmente nesta etapa funcionaram para os atores como as tintas de uma aquarela servem para os pintores que as manipulam, as moldam e as espalham na tela como melhor lhes agradam, a fim de que a expressividade pessoal artística tome forma. Assim, as técnicas do "aikido" e da "capoeira" neste processo serviram para os atores como as tintas para o pintor, a fim de que, uma vez aprendidas, pudessem ser manipuladas de acordo com a necessidade criativa, sendo o espaço, os parceiros e os demais elementos incluídos em sua tela de trabalho.

Sobre esse processo a atriz Helena Semedo comentou após um ensaio:

Achei muito bom o aquecimento de hoje com inclusão de diferentes estímulos e exercícios para me ajudar a concentrar e estimular minha criatividade. Sempre acho que quanto mais exercitamos no aquecimento, o trabalho de criação que vem na sequência fica mais potente, fico mais criativa. Além disso, em relação ao "aikido", o treinamento tem me ajudado a melhorar minha postura e a me movimentar com equilíbrio e harmonia. Já a "capoeira", com a ginga, tem me ajudado a me movimentar com mais agilidade e criatividade, traz um tônus diferente para o meu corpo e me oferece elementos diferentes do meu cotidiano.

Ignacio Muñoz, sobre sua experiência escreveu:

Para um ator não capoeirista como eu, o primeiro contato com o treino de "capoeira" é difícil. A "capoeira" é muito exigente e tem alguns elementos que não são fáceis para o não praticante: a contínua movimentação de pernas, tronco e braços cansa muito e nos primeiros ensaios a minha resistência era limitada. Também houve outras dificuldades: o apoio na parte frontal da planta do pé acaba causando dores até a pele endurecer e nas sessões muito longas era frequente sentir dor na lombar.

Dito isto, a consequência clara de todas estas dificuldades é que acabei melhorando sensivelmente minha condição física, ganhei um grande aumento da agilidade física e em geral uma disposição muito maior para realizar novos exercícios e movimentos. Portanto, foi este o primeiro benefício que senti da "capoeira" para o meu corpo.

Além do condicionamento físico, a "capoeira" possui movimentos interessantes com um importante valor estético que acabam enriquecendo o meu repertório de ator. No meu caso posso comentar que já tenho utilizado elementos inspirados na "capoeira" para outras 
atividades não relacionadas com esta pesquisa e que, com a repetição, vão ficando cada vez mais orgânicos para mim.

Já em relação ao "aikido", a prática de exercícios do nage me ajudou principalmente em relação à postura e à consciência corporal. O nage tem uma presença muito forte, sempre bem enraizado no chão e com uma grande limpeza e precisão nos movimentos. Estas características são essenciais para o ator, portanto praticar exercícios do nage para mim foi principalmente trabalhar no básico do ator. Depois de muitos meses de trabalho os resultados foram notáveis: postura mais firme, maior precisão dos movimentos, deslocamento mais harmônico, melhor utilização do centro de gravidade para manter o equilíbrio em cena e em geral um maior controle de todos meus movimentos. Os exercícios do nage também ofereceram grandes opções para aumentar o meu repertório de movimentos para o meu trabalho na cena. Os exercícios do uke ajudaram principalmente a melhorar a condição física (resistência e alongamento) e a exercitar a prontidão. Para mim o mais marcante do uke tem sido as torções que oferecem muitas alternativas e são um excelente campo de testes para o ator. No começo o natural é partir para as torções de braços ou mãos, mas nos exercícios fomos trabalhando torções maiores (tronco, pescoço...) e menores (dedos, músculos da cara). Outro ponto importante do nage e do uke é a esfericidade, que é um dos princípios que mais trabalhamos nos ensaios. Isto tem ajudado muito a melhorar a plasticidade dos movimentos e a utilizar os braços de uma forma mais conectada ao restante do corpo.

Murilo Rocha, a partir das experiências com o treinamento comentou:

O treinamento me ajudou a ter uma presença em cena mais consciente, com movimentos mais precisos e mais limpos. Em relação à conexão com a criação, me senti perdido a princípio. Não conseguia utilizar as técnicas para a criação cênica. Mas com o passar do tempo, fui ficando mais familiarizado com o repertório novo e fui tendo mais facilidade para utilizá-lo como estímulos criativos. Ao final, estava muito mais à vontade com a proposta.

Nesta etapa, a fim de ajudar os atores nestes estudos práticos individuais, de modo a terem mais consciência acerca do que estavam realizando, recorremos aos fatores de movimento identificados por Rudolf Laban, 1978, utilizando-os sempre a partir das necessidades surgidas durante a prática. Dessa forma, as técnicas escolhidas do "aikido" e da "capoeira" foram analisadas tendo em vista sua fluência, seu peso e a forma como se desenvolviam no espaço. Esta análise nos ajudou a extrair os princípios que nortearam as experimentações corporais desta etapa em diante. Os conceitos adotados por Laban, por consequência, foram importantes para que os atores pudessem se apropriar de um material técnico e expressivo até então desconhecido por eles, de modo que conseguissem desenvolver uma autonomia criativa e conquistassem uma 
consciência maior sobre os movimentos realizados. A seguir apresentamos de forma sucinta os fatores de movimento utilizados em nossas investigações práticas:

a) A fluência, de acordo com Laban, refere-se à integração do movimento trazendo uma sensação de unidade para as partes do corpo. Este conceito traz duas formas diversas de qualidades básicas que são: livre ou liberada e controlada ou contida (RENGEL, 2005, p. 64).

b) $\mathrm{O}$ fator espaço diz respeito à forma do agente se relacionar com o mundo que o circunda. As formas qualitativas básicas percebidas no agente são direta e flexível. O movimento direto é aquele que se mantém em uma trajetória ou em direção a um ponto. Já o flexível é o movimento definido por curvas, ondas e linhas indiretas, onde a atenção do agente é multifocada (RENGEL, 2005, p. 65-66).

c) Em relação ao peso podemos dizer que:

Elemento firme do esforço consiste de uma resistência forte ao peso e de uma sensação de movimento pesada. Já o elemento "leve do esforço consiste de uma resistência fraca ao peso e de uma sensação de movimento leve ou de ausência de peso. (LABAN, 1978, p. 120)

Os aspectos explicitados acima serviram de guia para o estudo prático das técnicas experimentadas durante o treinamento. A partir desses estudos fomos identificando, de acordo com nossas percepções, pontos importantes que foram sendo desenvolvidos nas experimentações como os indicados a seguir: no "aikido" vemos a fluência liberada do uke em contraposição à fluência controlada do nage; em relação ao peso, percebemos no nage movimentos sempre leves, enquanto no uke identificamos uma transformação de energia indo do pesado para o leve durante o desenvolvimento da relação com o nage; quanto ao espaço percebemos uma variação entre o movimento direto e o flexível, tendo em vista que inicialmente a atenção do nage se concentra no ataque e na sequência muda para muitas direções já que adota um movimento espiralado; na "capoeira", percebemos a leveza e a flexibilidade na ginga e na negaça, enquanto notamos o peso em movimentos mais próximos do chão como a rasteira e a negativa; quanto ao espaço, percebemos na "capoeira" movimentos flexíveis com uma atenção multifocada, uma vez que o jogo exige um deslocamento para muitas direções; quanto à fluência percebemos uma oscilação entre a controlada e a liberada, de acordo com o momento do jogo. 
Nosso objetivo durante toda esta etapa prática era de que todas as partes do corpo deveriam estar engajadas na realização do menor movimento, a fim de que o trabalho fosse potencializado pela concentração de energia proveniente do conjunto corporal. Corroborando este raciocínio, Laban explica que:

O corpo é nosso instrumento de expressão por via do movimento. $\mathrm{O}$ corpo age como uma orquestra, na qual cada seção está relacionada com qualquer uma das outras e é uma parte do todo. (...) Cada ação de uma parte particular do corpo deve ser entendida em relação ao todo que sempre deverá ser afetado. (LABAN, 1978, p. 67)

Laban, 1978, ao tratar do corpo funcionando como um todo, o faz seguindo a concepção adotada para este trabalho de que o corpo é uma estrutura única onde as partes de natureza física e psíquica estão conectadas e envolvidas em todas as ações. Laban, em seus estudos, portanto, considera o movimento não apenas em seus aspectos físicos, mas também interiores como os intelectuais e emocionais. Para ele a simples função motora não é suficiente para explicar as escolhas realizadas pelos seres humanos de acordo com cada situação vivenciada. Para ilustrar esse fenômeno cita como exemplo a movimentação de uma pedra rolando em direção ao fogo. Ela segue seu percurso natural ditada pela lei da gravidade independentemente da proximidade do perigo. Já o ser humano, em uma situação semelhante a esta, tomaria uma atitude interna no sentido de tentar barrar este movimento a fim de se preservar. Esta motivação em decidir sobre o que é melhor para si em cada momento demonstra um componente psicológico do movimento que vai além de suas funções motoras. Por esta razão argumenta que "cada simples gesto de qualquer parte do corpo revela um aspecto de nossa vida interior" (LABAN, 1978, p. 49). Há, desta forma, uma liberdade de escolha ao definir qual é o movimento mais adequado frente a determinada situação. A esta função que dá vida ao movimento Laban dá o nome de esforço, pelo qual os movimentos ganham expressividades diferentes, conforme exposto a seguir:

Todos os movimentos humanos estão indissoluvelmente ligados a um esforço o qual, na realidade, é seu ponto de origem e aspecto interior. $\mathrm{O}$ esforço e a ação dele resultante podem ambos ser inconscientes e involuntários, mas estão sempre presentes em qualquer movimento corporal; se fosse de outro modo, não poderiam ser percebidos pelos outros nem se tornar eficazes no meio ambiente da pessoa em movimento. (LABAN, 1978, p. 51-52)

Portanto, entendemos que para Laban o movimento não pode ser analisado de maneira isolada, haja vista, que da mesma forma que as partes físicas trabalham como 
uma orquestra, os impulsos internos, seja intelectual, ou emocional, devam ser considerados para a compreensão adequada do movimento. Como exemplo deste processo, podemos citar as experimentações em torno das técnicas kotegaeshi e sankyo que são torções realizadas pelo nage sobre o uke e que envolvem braço, antebraço e ombro. Experimentamos primeiramente de forma individual, de modo que os atores pudessem estudar a técnica em seu próprio corpo sem o contato com o parceiro. Tendo como referência a posição do $u k e$ nesta torção e os fatores de movimento apontados por Laban, os atores deveriam buscar em seus corpos outras variações da técnica de acordo com as possibilidades de cada um. Assim, a torção, a fluência controlada, o desequilíbrio e o uso do tônus presente nesta técnica, poderiam ser experimentados de outras formas além dos membros superiores. Neste caso percebemos o surgimento de outros movimentos que envolviam a expansão da torção para o corpo todo, a concentração da torção em partes específicas como quadril e pernas, a repetição de um trecho desta técnica gerando outras formas de expressividade corporal etc.

Imagens de 35 a 38: movimentos
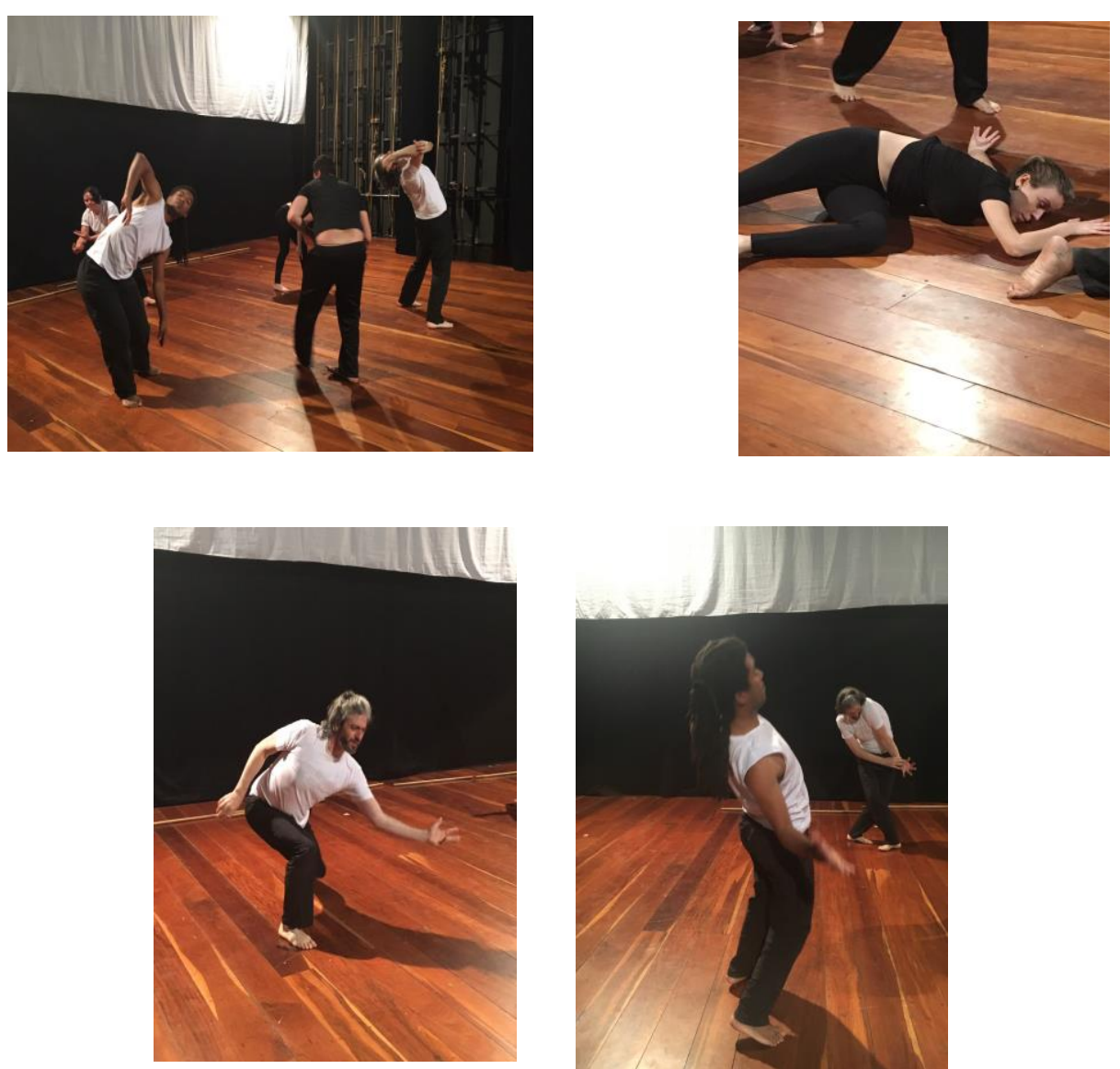

Fontes: arquivo do autor. 
A mesma experimentação sobre a técnica foi realizada considerando a posição do nage. Assim, a movimentação do quadril, o alinhamento da coluna, o relaxamento ativo e o deslocamento circular dos pés de forma estável serviram de estímulos para a busca de novas variações corporais. Neste processo, ao colocar em atividade todo o corpo, os fenômenos sensoriais eram estimulados, fazendo com que os atores se sentissem cada vez mais motivados a seguirem com a experimentação.

Imagem de 39 a 42: improvisos
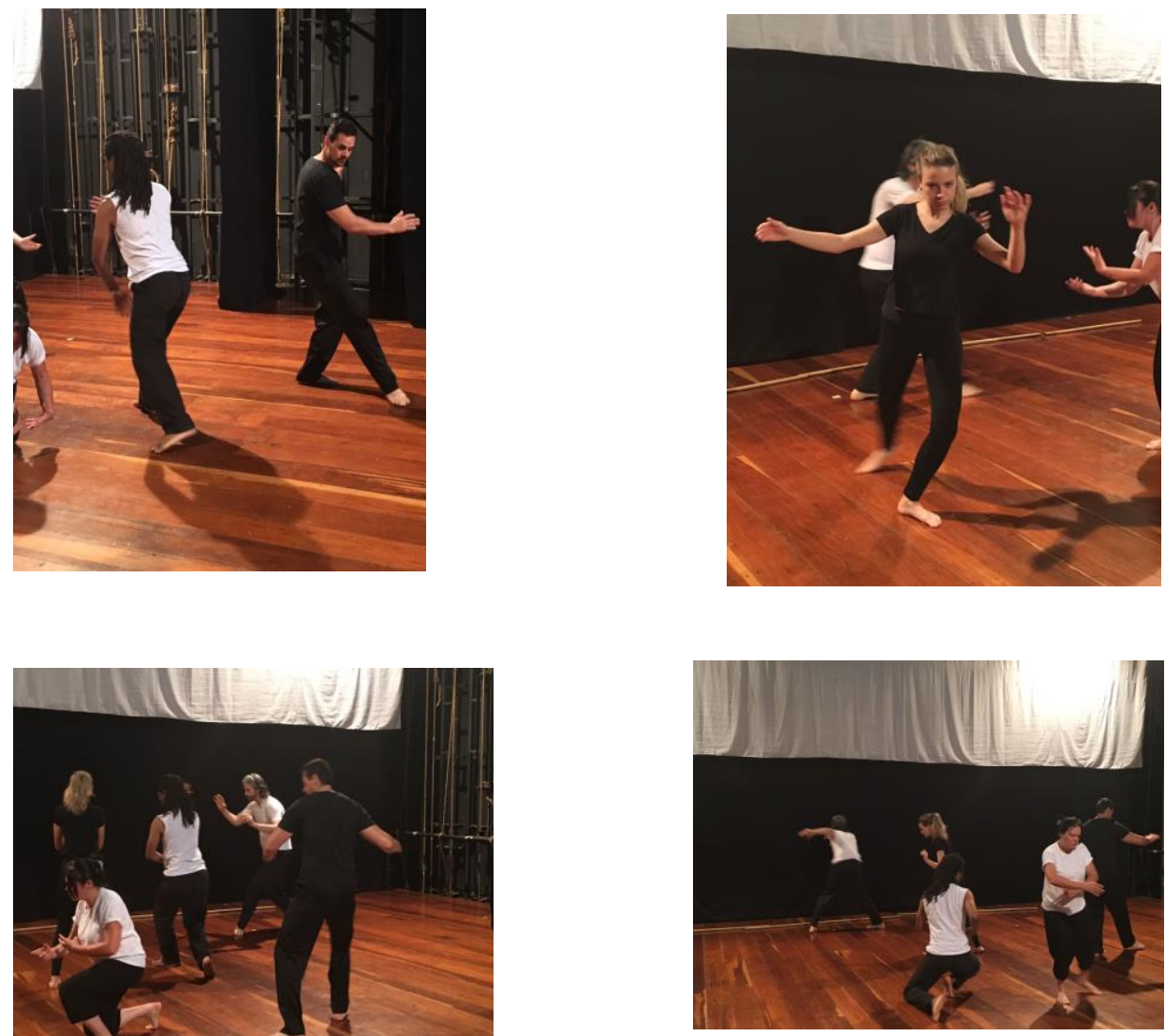

Fontes: arquivo do autor.

Esse procedimento foi utilizado junto com as outras técnicas selecionadas, de modo que os atores fossem construindo movimentos pessoais a partir dos elementos propostos. Estes estudos, conforme o treinamento avançava, foram realizados também em duplas. O que alterava é que, durante a movimentação, em vez do ator estar com o foco maior em si mesmo, ele deveria ser expandido incluindo o outro nesse processo de análise. 
Imagens de 43 a 46: movimentos pessoais


Fontes: arquivo do autor.

Outro exemplo de prática desta etapa foi a aprendizagem das técnicas com jo que, conforme já foi explicado, é uma arma em forma de bastão de madeira. Estas técnicas auxiliam na autoconscientização corporal, na concentração, na prontidão, na coordenação motora, no uso do corpo todo tendo como centro o quadril que ajuda a impulsionar o bastão, na conexão entre movimento e respiração, na reorganização postural e no uso do tônus. Quando manipulamos o jo se deve manter os ombros baixos e alinhados, sem tensão excessiva sobre eles, a coluna deve estar ereta e alongada, os pés posicionados em kamae para dar estabilidade ao corpo e a inspiração prepara o 
movimento enquanto a expiração dá a potência para a realização. Conectado à expiração existe a emissão do kiai, um som vocal explosivo coordenado com o movimento. O kiai foi utilizado na preparação dos atores como forma de treinar as habilidades vocais no uso correto do diafragma e para dar potência ao movimento. Acreditamos que todas as características presentes nestas técnicas são importantes para auxiliar o trabalho cênico na medida em que o ator, ampliando a consciência sobre si mesmo, canalizando corretamente a energia, usando adequadamente a musculatura e a respiração e assumindo uma postura corporal correta, pode fortalecer sua presença cênica. Este processo com o jo foi basicamente de repetição das técnicas de modo que os atores aprimorassem as habilidades corporais aqui apontadas, e se familiarizassem com este objeto até o ponto em que começassem a senti-lo como uma extensão de seu próprio corpo.

Acerca desse tipo de treinamento, Burnier (2001, p. 117) explica que "esse treinamento visa desenvolver uma relação ator-objeto onde os impulsos das ações do ator são transportados para o objeto, e a dinâmica espacial do objeto é transferida para o corpo do ator". Temos, assim, que o treino com o jo pode auxiliar à melhor percepção do próprio corpo em movimento em relação ao espaço. Este é um ponto importante da preparação, pois o trabalho com objetos para o ator, comum em muitos grupos de teatro, proporciona uma vivência específica que varia de acordo com a forma, a espessura, o peso, a maleabilidade, o material e o tamanho do objeto. Todas estas qualidades afetam a dinâmica do movimento, exigindo do ator uma ampliação de sua percepção durante a manipulação para perceber as possibilidades que este objeto pode trazer.

Esta etapa foi bastante difícil para alguns atores, pois se trata de técnicas muito detalhadas em relação ao uso do corpo, exigindo, assim, paciência e persistência. Com o decorrer dos treinos algumas dessas dificuldades foram superadas e a manipulação do jo foi se tornando mais tranquila. Alguns atores escreveram os seguintes depoimentos sobre a experiência do treinamento com o bastão:

Helena Semedo: "O treinamento com o bastão me ajudou a melhorar a postura, o tônus, a coordenação motora e fortalecer a musculatura".

Ignácio Muñoz:

O mais importante que percebi com o bastão é que trabalhamos com um objeto tangível, com um peso e uma textura. Sinto que isso influencia diretamente a qualidade do movimento: é mais firme, mais preciso e mais consciente. O bastão por tanto ajuda bastante na consciência corporal e na precisão dos movimentos. Eu tenho certeza 
que minha postura tem melhorado significativamente desde que começamos trabalhar com o bastão. Às vezes nos ensaios, durante o trabalho com alguma cena, me imagino segurando um bastão. É uma grande ajuda, pois imaginando o peso e tato do bastão é possível recuperar essa firmeza no movimento.

Como exemplificação de processo envolvendo a "capoeira", podemos citar os estudos práticos com a ginga. Para a experimentação propusemos uma separação das características dessa técnica, de modo que, os atores pudessem partir de focos específicos. Assim, utilizamos as seguintes referências: o impulso sobre o metatarso, a agilidade na movimentação, deslocando-se continuamente pelo espaço e mudando de direção e a sinuosidade partindo principalmente da coluna e do quadril. Incluímos nessa investigação a negaça que é a movimentação sinuosa quando se está na base paralela da ginga. Foi solicitado que se movimentassem livremente pelo espaço pensando apenas no impulso sobre o metatarso. Em seguida, realizaram a mesma experimentação pensando apenas na sinuosidade da coluna e assim por diante, até passar por todas as referências selecionadas. A partir disso identificamos as seguintes características, tendo como base os fatores de movimentos aqui explicitados: liberada, considerando a fluência; multifocada, considerando o espaço; e leve, considerando o peso. Procedemos de forma semelhante com as demais técnicas selecionadas da "capoeira" de modo que pudéssemos entender corporalmente qual era a essência de cada uma.

Imagens 47 e 48: movimentos
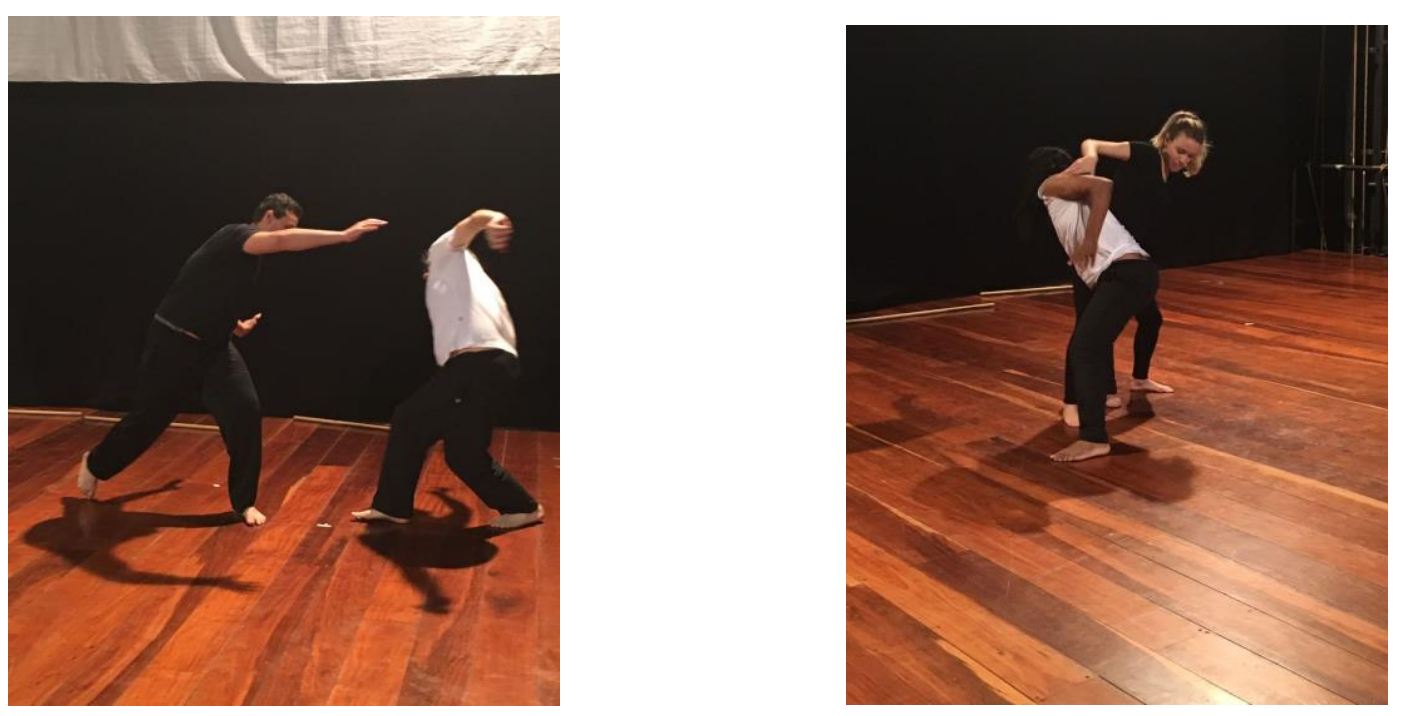

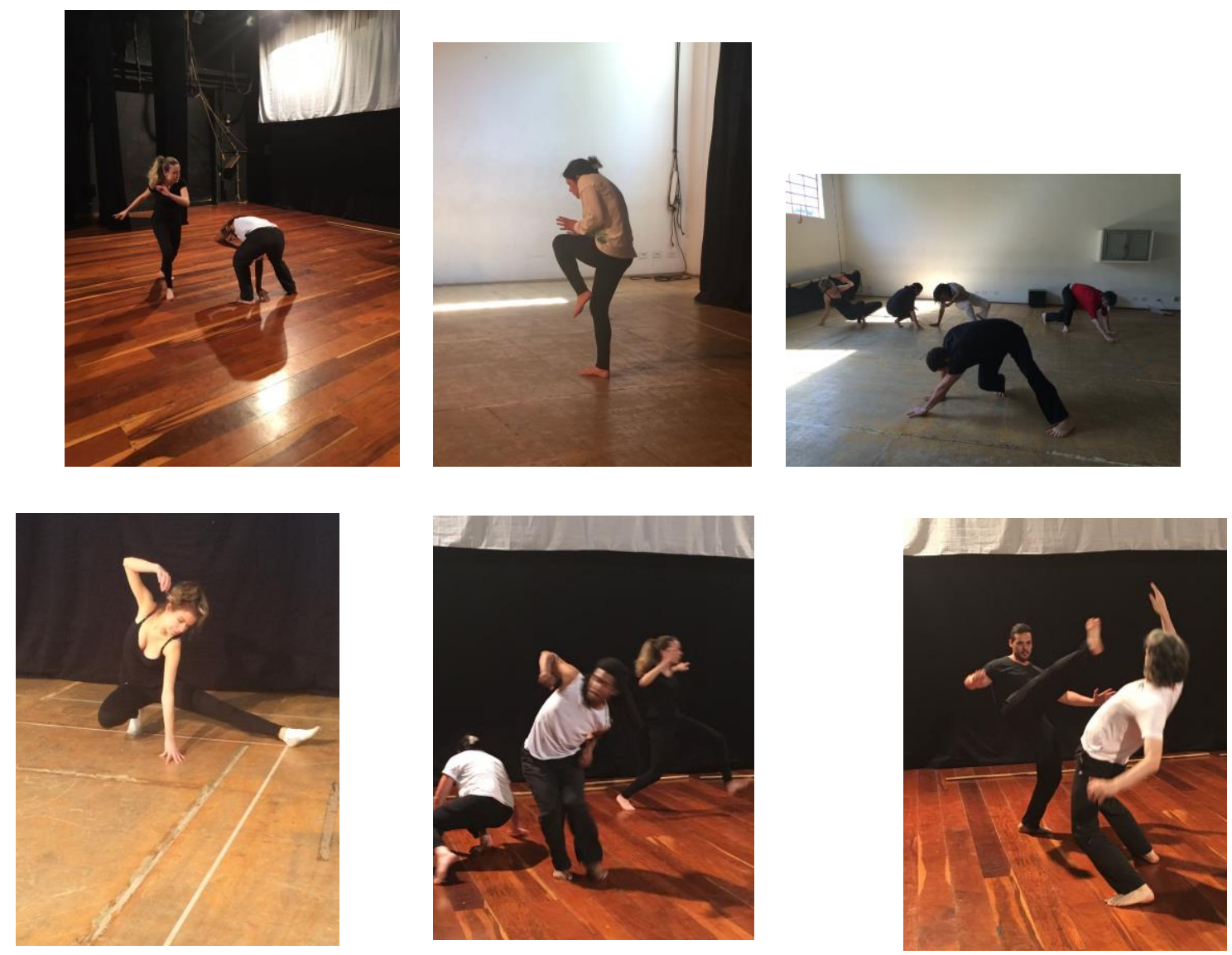

Fontes: arquivo do autor.

Sobre esse processo o ator Ignacio Muñoz comentou:

No início do treinamento identifiquei como problemas a dificuldade em realizar algumas técnicas propostas e o condicionamento físico. Sentia que os detalhes presentes nestas técnicas (posição dos pés, dos braços, a flexão dos joelhos etc.) me atrapalhavam mais do que me ajudavam, me deixando mais tenso. Com o passar do tempo, repetindo e repetindo fui ganhando fluidez e lidar com esses detalhes deixou de ser tão complicado. Por exemplo, achei a ginga muito difícil no começo. O meu movimento era duro, sem molejo, minha coluna ia ficando torta, às vezes me atrapalhava na execução. Depois de um tempo, fui sentindo mais facilidade e fui descobrindo minha forma de gingar. Isso influenciou posteriormente o meu trabalho criativo quando utilizei esta técnica para a criação cênica. Da mesma forma, o caminhar do "aikido" (tenhan, irimitenkan, passo e sobrepasso) foi difícil a princípio, mas, aos poucos, fui me ajustando e se tornou mais fácil.

No mesmo sentido, a atriz Helena Semedo comentou:

Este treinamento me ajudou a perceber a importância dos braços em conexão com meu corpo todo. No caminhar do "aikido", por exemplo, fui aos poucos percebendo que meus braços ficavam travados em uma mesma posição e não fluíam junto com o restante do corpo. Gradativamente fui tomando consciência disso e fui conseguindo 
realizar movimentos mais bonitos. Sinto que minha coordenação motora melhorou também porque hoje consigo fazer movimentos que antes eram muito difíceis para mim como a ginga e movimentos com o bastão.

De tudo que foi vivenciado nesta fase foram extraídos princípios que permearam todo o processo, especialmente a criação, e que seguem expostos a baixo:

A) A grande potência do "aikido" conforme já dissemos está na relação entre o uke e o nage. A conexão entre eles presentifica os ideais de Sensei Morihei Ueshiba a cerca da conexão do indivíduo com o próximo e com o que mundo que o envolve. Para tanto, nos treinamentos, para fins didáticos, identificamos os princípios que regem cada uma das técnicas e movimentações realizadas pelo uke e pelo nage, a fim de que o ator pudesse ter apoios claros para improvisar, conforme segue exposto.

A1) A partir das qualidades de movimento apresentadas pelo nage, identificamos os seguintes princípios como impulsionadores do trabalho corporal, criativo e expressivo do ator:

a. centro do corpo como impulsionador dos movimentos que se irradiam para as extremidades como braços e pernas (uso do quadril como potencializador dos movimentos);

b. base equilibrada e estável;

c. coluna vertebral funcionando como o eixo da esfera;

d. movimentos espiralados e circulares;

e. deslocamento e apoios sobre os joelhos, possibilitando a exploração dos níveis médio e baixo ${ }^{30}$;

f. respiração como forma de se aproximar de um estado mais relaxado e tornar os movimentos mais potentes, uma vez que é por ela que é possível trabalhar a expansão do ki e, por consequência, a concentração.

g. foco no parceiro ao mesmo tempo em que mantém a percepção do espaço como um todo;

h. relaxamento ativo, ou seja, sem tensão desnecessária, mas em estado de prontidão;

\footnotetext{
${ }^{30}$ Para Laban, nível espacial diz respeito a altura: baixa, média e alta.
} 
i. uso da força centrífuga na relação com o parceiro a partir da ideia de que um pode atrair o outro para o seu centro, desenhando uma espiral no espaço;

j. uso da força centrípeta na relação com o parceiro como continuidade da trajetória centrífuga iniciada anteriormente;

k. aproveitamento da energia recebida do parceiro pela aproximação e contato físico;

1. diferentes formas de reações a partir das diferentes formas de contato físico.

A2) Em relação às qualidades de movimento produzidas pelo uke elaboramos os seguintes princípios:

a. movimentos fluindo da extremidade para o centro;

b. mudanças em relação ao equilíbrio: estabilidade, desequilíbrio parcial e total (queda);

c. torções e movimentos sinuosos;

d. percepção do parceiro e do espaço durante todo o tempo;

e. respostas corporais ágeis e adaptações rápidas a partir da proposta corporal do parceiro;

f. afetação pelo contato corporal com o parceiro;

g. contato do corpo todo com o chão;

h. diferentes formas de aproximações e contatos com o parceiro, impulsionando-o para diferentes reações;

i. variações de tônus, do pesado ao leve, especialmente como resultado do contato com o parceiro.

B) Da "capoeira" extraímos os seguintes princípios:

a. uso de animais presentes em algumas técnicas da "capoeira" como a cobra, o macaco e a arraia. Como ilustração desse item, podemos apontar algumas técnicas a fim de tornar clara esta conexão: a ginga traz a sinuosidade e a leveza da cobra; o macaquinho - salto para trás - se assemelha ao movimento do macaco; o rabo de arraia chute giratório de baixo para cima - tem trajetória semelhante a da arraia.

b. espiralidade com a torção do corpo, impulsionado pelo movimento do quadril; 
c. molejo e impulsos a partir do metatarso;

d. relação com o chão a fim de conseguir estabilidade e impulso;

e. engajamento do corpo como um todo, onde todas as partes se interconectam e se afetam mutuamente;

f. recolhimento em direção ao centro e expansão a fim de concentrar energia e ganhar potência;

g. continuidade e fluência do movimento;

h. exploração dos níveis do espaço recorrendo a diferentes apoios como mãos e pés.

Isabella Leonel, atriz que também participou de toda a parte prática compartilhou as seguintes impressões a partir das experiências vivenciadas:

Usar a prática do "aikido" e da "capoeira" como preparação para a construção de cenas para essa peça, foi um desafio para mim desde o começo, pois eu não tinha conhecimento nenhum dessas duas artes marciais. Após um longo estudo individual de cada uma delas, passando por cada movimento e o treinando isoladamente para entender a técnica do movimento, passamos a desconstruí-lo, já que a proposta da diretora era que os movimentos e ações fossem apenas baseados e inspirados nas técnicas. Isso me deixou mais a vontade para a cena. A repetição dos movimentos extraídos do "aikido" e da "capoeira" foi importante porque com o tempo eles passaram a ser naturais e eu não me preocupava mais em acertar tecnicamente, e, partindo dos princípios que os fundamentavam, começamos a construção das cenas que foram todas feitas a partir dos estímulos das artes marciais e das improvisações dos atores. Além disso, com estes treinamentos, percebi em mim uma melhora do condicionamento físico, do equilíbrio, da flexibilidade, da concentração, dos reflexos, da intuição etc.

Todos estes princípios foram aproveitados na etapa seguinte que focou a improvisação e o jogo.

\subsection{Improviso e jogo}

Nesta etapa de investigação dos atores foi utilizado como recurso principal o improviso e o jogo. O improviso aparece em muitas formas de arte, recebendo mais destaque no teatro, como parte de sua essência. Desde suas origens o teatro utiliza-se do improviso como recurso para estimular a criação. Considerando como improviso a habilidade do ator/improvisador de criar novas possibilidades a partir de alguns referenciais colocados e de se adaptar a circunstâncias novas, criando caminhos e 
soluções novos. Neste sentido, de certa forma, a etapa descrita anteriormente teve também características do improviso, uma vez que os atores, por meio de seus estudos, deveriam buscar possibilidades novas a partir das técnicas propostas. Todavia, o que diferenciou a etapa de improvisos da anterior foi a qualidade da atenção dos atores. Enquanto na fase de aprendizados da técnica e estudo, a atenção do ator estava voltada para identificar os princípios que fundamentavam cada técnica, tendo como suporte os fatores de movimento de Rudolf Laban, 1978, na etapa de improvisos os princípios já eram dados e serviam de impulso para as experimentações criativas dos atores, que chamamos aqui de improvisações. Como nesta fase o foco não era mais estudar o movimento, mas criar corporalmente a partir de um princípio dado, outros elementos foram acrescidos a fim de que a improvisação ficasse mais estimulante, conforme se verá no decorrer desse capítulo.

Voltando ao improviso para o trabalho criativo, Spolin, 2003, alia a noção de improvisação a de experiência alegando que todos são capazes de improvisar desde que se entreguem verdadeiramente ao ato de experienciar. Afirma, a partir disso que "é na capacidade individual para experienciar que a infinita potencialidade de uma personalidade pode ser evocada. Experienciar é penetrar no ambiente, envolver-se total e organicamente com ele" (SPOLIN, 2003, p. 3). Com isto Spolin aponta como aspectos que devem estar presentes no improviso a espontaneidade e a liberdade pessoal, que permitem ao jogador um envolvimento genuíno com os parceiros e com o entorno, deixando de agir apenas pelo intelecto e antevendo atitudes. Neste estado o jogador vivencia o aqui e agora com seu corpo todo atuando de forma intensa. Seguindo esse entendimento Spolin argumenta que:

A espontaneidade cria uma explosão que por um momento nos liberta de quadros de referência estáticos, da memória sufocada por velhos fatos e informações, de teorias não digeridas (...). A espontaneidade é um momento de liberdade pessoal, quando estamos frente a frente com a realidade e a vemos, a exploramos e agimos em conformidade com ela. Nessa realidade, nossas mínimas partes funcionam como um todo orgânico. É o momento de descoberta, de experiência, de expressão criativa. (SPOLIN, 2003, p. 4)

Segue ainda explicando que "nessa espontaneidade a liberdade pessoal é liberada, e a pessoa como um todo é física, intelectual e intuitivamente despertada" o que faz com que o jogador "transcenda a si mesmo" (SPOLIN, 2003, p. 5).

Nesse processo de atuar espontaneamente por meio do improviso, reforça-se a liberdade pessoal a fim de que a experiência seja plena. A liberdade individual, 
entretanto não está desatrelada da ideia de grupo, pois normalmente o improviso acontece de forma relacional. Um bom exemplo de atividade relacional que pressupõe a presença de um grupo e que lança mão das habilidades de improvisação é o jogo que pode propiciar uma forma natural de integração dos envolvidos na atividade. Spolin aponta que:

Os jogos desenvolvem as técnicas e habilidades pessoais necessárias para o jogo em si, no próprio ato de jogar. As habilidades são desenvolvidas no próprio momento em que a pessoa está jogando (...) e recebendo toda a estimulação que o jogo tem para oferecer. (SPOLIN, 2003, p. 4)

Pelo exposto apreende-se que o jogo é extremamente importante na vida do ser humano, independentemente de sua ligação com a arte, pois o ajuda a aprimorar habilidades que em sua vida cotidiana nem sempre é possível. Huizinga, 2014, reforça esta importância afirmando que toda e qualquer atividade humana pode ser considerada jogo e que é pelo jogo que a civilização surge e se desenvolve. Temos assim, que é uma atividade que permeia a vida de uma forma total, contribuindo inclusive para a construção de uma identidade social e cultural.

Tratando dos aspectos práticos dos jogos, Schechner aponta que:

(...) o ato de jogar acontece quando existe suficiente energia metabólica, um nível baixo de estresse, uma necessidade de estimulação e a inteligência suficiente para manejar sequências complexas de comportamento improvisado em algum grau. ${ }^{31}$ (SCHECHNER, 2012, 169)

Podemos entender, portanto, que o grau de entrega e de comprometimento a este tipo de atividade dependerá da tranquilidade, da energia metabólica, da coordenação motora e da inteligência do jogador, possibilitando assim o trabalho da musculatura e um livre desenvolvimento das ações e dos movimentos. Nesse estado de disponibilidade e de preparo físico:

31. "En um sentido etológico, el juego y el ritual se encuentran estrechamente relacionados. Del mismo modo en que el ritual tiene raíces que vienen del comportamiento animal no humano, también se ha observado la presencia del juego em muchas espécies (...) Desde el punto de vista etológico, e lacto de jugar sucede cuando hay suficiente energia metabólica, um nível bajo de estrés, uma necessidade de estimulación y la inteligência suficiente para manejar secuencias complejas de comportamiento improvisado em algún grado.” ( SCHECHNER, 2012, p. 167) 
Todas as partes do indivíduo funcionam juntos como uma unidade de trabalho, como um pequeno todo orgânico dentro de um todo orgânico maior que é a estrutura do jogo. Dessa experiência integrada, surge o indivíduo total dentro do ambiente total e aparece o apoio e a confiança que permite ao indivíduo abrir-se e desenvolver qualquer habilidade necessária para a comunicação dentro do jogo. (SCHECHNER, 2003, p. 5-6)

Esta integração que pode ser observada em um jogo proporciona desenvolvimento em termos sociais e individuais a todos os envolvidos, ao mesmo tempo em que possibilita um estado de relaxamento, uma vez que os jogadores, estando integrados entre si e com o ambiente, sentem-se livres e seguros para se manifestarem. Este relaxamento, portanto, abre a possibilidade para a potencialização da expressividade pessoal e da socialização, pois permite que os jogadores entrem em contato com o mundo que o cerca de forma viva, real e presente.

Apreende-se disso que o jogo tem como outro aspecto importante o de provocar mudança no estado interno de quem os pratica, transportando os participantes para uma segunda realidade, ou seja, para uma dimensão diferente do cotidiano vivido por eles. Trata-se de um intervalo, uma suspensão no estado costumeiro da pessoa, que pode conduzi-la a um estado mais relaxado, tranquilo, energético, de transe ou até de euforia, dependendo do tipo do evento e do grau de envolvimento. O jogo tem como um dos objetivos funcionar como via de escape para as tensões do dia a dia, conduzindo o jogador a um padrão mais descontraído e leve. Além disso, em virtude da atmosfera descontraída que pode ser instaurada, o jogo ajuda a promover a interação e a comunhão entre as pessoas. Ortega y Gasset explica:

O jogo, pois, é a arte ou técnica que o homem possui para suspender
virtualmente sua escravidão dentro da realidade, para evadir-se,
escapar, trazer-se a si mesmo deste mundo em que vive para outro
irreal. Este trazer-se da vida real para uma vida imaginária,
fantasmagórica é distrair-se. (ORTEGA y GASSE, 1991, p. 55)

E esta distração não é prioridade das crianças, embora seja na infância que mais nos envolvemos com atividades lúdicas. Na fase adulta o jogo ajuda a transportar o ser humano para uma atmosfera mais leve onde os problemas temporariamente ficam suspensos e dão espaço para o prazer e a diversão.

Huizinga, 2014, também comenta sobre o caráter de divertimento presente no jogo ressaltando que é na intensidade e no poder de fascinação que ele provoca que reside sua essência e característica primordial. Acrescenta ainda que: 
A própria existência do jogo é uma confirmação permanente da natureza supralógica da natureza humana. Se os animais são capazes de brincar é porque são alguma coisa mais que seres mecânicos. (HUIZINGA, 2014, p. 6)

Esta natureza supralógica também se conecta ao poder imaginativo que está muito presente neste processo de instauração de outra vida que o afasta temporariamente de seu dia-a-dia. O homem, ao jogar, imagina outra realidade, manipula imagens, "como se o espírito estivesse saltando entre a matéria e as coisas pensadas (...) Ao dar expressão a vida, o homem cria um outro mundo, o mundo poético" (HUIZINGA, 2014, p. 7). Estas ideias entram em consonância com o que viemos abordando durante toda a pesquisa a respeito do homem como um ser composto de partes de natureza física, intelectual e emocional, que se afeta pelo mundo que o envolve, construindo e criando histórias pessoais, de acordo com a forma como se apropria e absorve as informações utilizando suas funções sensório-motoras. Ao tirá-lo de sua vida cotidiana, padronizada e regrada, o jogo o coloca em circunstâncias que o obrigam a criar e se adaptar, estimulando seu poder imaginativo.

Outra característica que vale ser ressaltada acerca do jogo é a delimitação de espaço. Sua capacidade de levar o homem para além da vida comum tem relação com a definição de um espaço específico que auxilia na criação desse mundo temporário. Huizinga (2014, p. 13) explica que "todo jogo se processa e existe no interior de um campo previamente delimitado, de maneira material ou imaginária, deliberada ou espontânea". É o estabelecimento de um espaço lúdico que torna esta atividade tão especial em um mundo repleto de atividades habituais e comuns.

Outro aspecto importante a ressaltar sobre o jogo é que, apesar de trazer o diferente e estimular a criatividade permitindo a instauração de situações e relações novas, segue condutas e regras que dão ordem a sua prática. Estas regras caminham lado a lado com os aspectos subjetivos de cada jogador e com sua expressividade pessoal que fundamentam as atividades lúdicas.

Corroborando com este pensamento, Viola Spolin apresenta uma definição de jogo que se assemelha ao que foi exposto por Schechner, 2003, conforme segue abaixo:

O jogo é uma forma natural de grupo que propicia o envolvimento e a liberdade pessoais necessários para a experiência. Os jogos desenvolvem as técnicas e habilidades pessoais necessárias para o jogo em si, através do próprio ato de jogar (...) Está subentendido que durante o jogo o jogador é livre para alcançar seu objetivo da maneira 
que escolher, desde que obedeça as regras do jogo (...). (SPOLIN, 2003, p. 4)

A esse respeito, Koudela, 1996, explica que comumente a regra é entendida e recebida como um ato de autoridade, entendimento este que se choca com o objetivo de descontração e de liberdade presentes nos jogos. Entretanto, ela esclarece que:

$\mathrm{Na}$ instituição lúdica, a regra pressupõe processo de interação. $\mathrm{O}$ sentido de cooperação leva ao declínio do misticismo da regra quando ela não aparece como lei exterior, mas como o resultado de uma decisão livre porque mutuamente consentida. Evidentemente, cooperação e respeito mútuo são formas de equilíbrio ideais, que só se realizam através de conflito e exercício da democracia. (KOUDELA, 1996, p. 49)

As regras nesses tipos de atividade têm, portanto, como principal objetivo oferecer conforto e harmonia para o grupo, uma vez que instaura uma organização que possibilita com que todos os participantes tenham a oportunidade de se colocar e agir de forma equilibrada, diminuindo as tensões em razão de desavenças e embates localizados. Acerca disso, Huizinga, 2014, defende que o jogo

Cria ordem e é ordem. Introduz na confusão da vida e na imperfeição do mundo uma perfeição temporária e limitada (...) É talvez devido a esta afinidade profunda entre ordem e jogo que este (...) parece estar em tão larga medida ligado ao domínio da estética. Há nele uma tendência para ser belo. (HUIZINGA, 2014, p. 13)

A presença das regras em um jogo tanto possibilita a instauração da ordem, dando certa estabilidade ao grupo, como também abre espaço para a criação de novas estratégias e até de quebra das regras como acontece em alguns jogos que não tem como característica o apego a uma ordem estabelecida e tem como parte da diversão rodear as regras e burlá-las (SCHECHNER, 2012).

Estes pesquisadores, ao tratar dos jogos, apontam características importantes e que podem afetar sobremaneira a qualidade de vida das pessoas, em que envolve a liberdade de expressão, o desenvolvimento de habilidades, a interação dentro de um grupo, a presença de elementos definidos como técnicas e regras e a experiência pessoal. O jogo é uma forma de se relacionar com o mundo e está presente em todas as relações sociais, promovendo a vivacidade e a graça do movimento e do corpo humano, ensinando, desenvolvendo, capacitando e potencializando em qualquer fase ou idade (HUIZINGA, 1999). Embora seja mais frequente na infância, o ato de jogar não é uma prática exclusiva da criança, fazendo-se presente ao longo de toda vida do indivíduo. 
Outra característica presente nos jogos, e que consideramos conveniente abordar neste trabalho, é a presença dos observadores. É comum encontrarmos na prática dos jogos algumas pessoas jogando e outras assistindo. Estas últimas podem, dependendo da natureza da atividade lúdica em questão, ter um envolvimento mais ativo ou mais passivo, podendo, em alguns casos, inclusive interferir diretamente no andamento do jogo como é o caso dos árbitros. Schechner (2012, p. 160) a respeito desse assunto aponta que "os observadores podem estar ativamente envolvidos no jogo ou podem ser testemunhas mais desinteressadas. Há também os observadores profissionais, os árbitros e juízes que garantem que o ato de jogar siga as regras”. Temos, portanto, que o jogo não se resume aos jogadores e que, dependendo do caso, o observador ocupa função importante no desenrolar da atividade desenvolvida.

Por fim, convém ressaltar um último aspecto relevante para as práticas lúdicas: a fluidez, assim como é apresentada por Mihaly Csikszentmihalyi, 1975. Conforme já expusemos, via de regra, uma pessoa que pratica determinada atividade por um período longo de tempo e de forma repetida alcança um nível de experiência que a liberta da preocupação com pontos específicos como técnicas e regras e da insegurança. A fluidez está presente quando o corpo todo realiza uma ação com a atenção direcionada para o conjunto da atividade de forma livre e disponível. Para este psicólogo, no caso do jogo, a fluidez permite um total controle por parte do jogador uma vez que ele e o ato de jogar se fundem, passando a ser um só. Por esta razão, a prática regular, disciplinada e constante é também essencial para o bom andamento de um jogo, já que, quanto maior a experiência do jogador, maior será a fluidez.

Tendo sido apresentadas as principais características do improviso e do jogo, vamos agora relacioná-las às duas artes marciais aqui pesquisadas.

Comparando o que foi exposto com o jogo da "capoeira", percebemos rapidamente uma conexão, uma vez que a própria "capoeira" apresenta o termo "jogo" para designar a prática interativa entre dois participantes no centro de uma roda. Se analisarmos o jogo da "capoeira", percebemos que estão presentes todos os elementos abordados pelos autores acima como transportar os participantes para outro estado, relaxar as tensões do dia-a-dia, desenvolver habilidades específicas, dentre outros. Em relação às regras já tratamos de forma geral em capítulo específico e vimos que há uma organização para o andamento das rodas, variando as especificidades de grupo para grupo. No que diz respeito aos toques, por exemplo, na "capoeira angola" o ritmo é mais devagar que na regional, portanto, os movimentos são mais lentos e cadenciados. 
Além disso, na "angola" os jogadores ficam mais próximos uns dos outros e seus movimentos tendem a ser mais próximos do chão, recorrendo-se bastante ao apoio das mãos. Diferentemente, na "capoeira regional” o toque é mais rápido e o jogo tende a se desenvolver no nível alto, permitindo uma distância maior entre os jogadores e maior número de movimentos acrobáticos. Acrescenta-se ainda que a condução das rodas de "capoeira" seguem normalmente trâmites semelhantes independentemente do grupo como os seguintes: uma ordem específica de músicas, uma forma definida de entrar e sair do jogo, a presença de um espaço circular, dentre outros já expostos. Tem-se, portanto, uma quantidade de regras estabelecidas que devem ser obedecidas a fim de que a roda siga em harmonia. Operando juntamente com essa ordem está a liberdade dos jogadores para improvisarem e se relacionarem com os parceiros de maneira pessoal. Vemos, portanto, neste caso, a liberdade de expressão caminhando lado a lado com o rigor das regras. Huizinga, 1999, apresenta algumas palavras para descrever o jogo e que poderiam ser aplicadas à descrição da "capoeira" em si que são: tensão, equilíbrio, compensação, contraste, variação, solução, união e desunião. Durante um jogo percebemos estas palavras presentificadas no crescente grau de tensão e de energia da roda estimulados pelos toques, na busca constante dos jogadores de criação de estratégias por meio de movimentos leves e pesados em diferentes níveis espaciais, na variação entre momentos de descontração e de tensão, na obediência ao toque de berimbau a fim de manter a ordem, na mandinga, na brincadeira com o parceiro, dentre outros momentos. Além disso, podemos dizer que a potencialidade que a "capoeira" tem de afetar qualitativamente a vida das pessoas está justamente na possibilidade de experimentar movimentos que mobilizam o corpo todo, permitindo uma melhora de todo o estado psicofísico, potencializando as qualidades e oferecendo desafios, além de permitir a relação entre as pessoas e a expressividade pessoal.

Por sua vez, analisando o "aikido", não encontramos o termo “jogo" em nenhuma literatura sobre o tema. Entretanto, a partir dos elementos aqui apontados podemos identificar em que pontos o ato de jogar e improvisar estão presentes na prática do "aikido". Como foi exposto por Huizinga, 1999, todas as atividades humanas podem ser consideradas jogo. Assim, entendemos que, ainda em práticas que não são tidas conscientemente como tal, podem ser assim tratadas na medida em que têm em sua natureza os elementos necessários para a instauração de um jogo. A respeito do "aikido" temos um elemento importante que é a relação com um parceiro, ou seja, não é praticado sozinho. Em segundo lugar, nesta arte marcial, existem regras bem 
estabelecidas acerca do início e do término, da vestimenta, do tratamento entre os praticantes, bem como do lugar definido para a prática que é o dojo. Esta ordem, apesar de conter certo grau de rigidez, permite uma pessoalidade e uma subjetividade especialmente na forma de se realizar as técnicas. Em outras palavras podemos dizer que o improviso e a pessoalidade na maneira de lidar com as técnicas estão sempre presentes durante os treinos. E por fim, durante a prática, o aikidoista é transportado para outro estado, de maior concentração e energia, diferente do que ele se depara em seu dia a dia. Como exemplo de uma atividade aikidoista e lúdica podemos citar o jyuwasa que é uma dinâmica que tem como regra a presença de ataques simultâneos e aleatórios sobre uma única pessoa. Neste "jogo" podem estar presentes um ou mais atacantes, uke. Algumas vezes, em vez de deixar à escolha dos aikidoistas, define-se qual o tipo de pegada que será permitida, ou seja, em que parte do corpo o nage poderá ser preso e em que base deverão se colocar, ai hanmi ou gyaku hanmi. É uma atividade de improviso, pois, além do aspecto subjetivo da realização das técnicas que já mencionamos, não existe uma sequência de técnicas pré-definidas e que devem ser seguidas, mas, ao contrário, o nage poderá recorrer à técnica que melhor lhe aprouver no momento do ataque e para a qual estiver mais preparado. Nesta dinâmica não existe tempo para pensar ou planejar, devendo o pensamento acontecer com o corpo todo a partir da conexão com o parceiro. O uke, após o ataque sobre o nage, também não pode definir previamente o que fará na sequência, pois deve se relacionar com o que for proposto pelo nage no momento exato do contato físico entre os dois. Pelo exposto, percebemos que, da mesma forma que na "capoeira", a relação com o parceiro, a pessoalidade na apropriação das técnicas, o desenvolvimento de potencialidades, a superação de dificuldades, a elaboração de estratégias e a instauração de um mundo imaginário devem estar presentes o tempo todo.

De todas as características apresentadas das duas artes marciais, podemos perceber que, apesar de cada uma ter sua especificidade, possibilitando desenvolvimentos individuais e coletivos diferentes, existe um aspecto que permeia ambas que é a fluidez. A fluidez, que vem com a prática regular e com a experiência, é intensificada nestas artes por serem atividades que não enfocam as figuras do ganhador e do perdedor, ou seja, a comunicação entre os parceiros é o grande objetivo. O "aikido" afasta expressamente a competição, seguindo os preceitos de Morihei Ueshiba, e coloca a cooperação como principal característica da relação entre os aikidoistas. Assim, durante um treino, uke e nage não são rivais que se defrontam, mas parceiros que 
comungam de um momento de interação recíproca. Da mesma forma, a "capoeira", não enfoca o embate entre dois rivais, mas sim o "diálogo corporal" entre duas pessoas. A ideia da competição não é o foco de nenhuma das duas artes, portanto. Algumas vezes a competitividade está presente como em jogos onde os capoeiristas se defrontam de modo mais firme e com mais agressividade, dando uma ideia maior de combate e em competições de cantiga, toque e jogo que alguns grupos organizam entre si. Entretanto, mesmo nestes momentos, se mantém o fundamento do diálogo corporal de maneira fluida. O que interessa nesse tipo de relação é o andamento do jogo dentro do ritmo estabelecido e com os parceiros em sintonia.

Tratando acerca da nocividade da competição para o bom andamento do jogo, Spolin, 2006, explica que "competições fragmentam uma pessoa e isolam um jogador de seus parceiros e destroem parte do todo. (...) Quando a marcação é mais importante do que os jogadores e o jogo, valores pessoais são distorcidos pela necessidade de vencer" (SPOLIN, 2006, p. 439). Para Spolin, portanto, um ambiente altamente competitivo, aumenta a tensão entre os membros rompendo com a harmonia, pois os envolvidos deixam de pensar na relação com o grupo e passam a pensar só neles próprios e na necessidade de derrotar o outro. Nesse estado, o outro passa a ser uma ameaça e, por isso, acaba despendendo uma grande energia em combatê-lo. O resultado disso é a separação entre os jogadores e a diminuição da liberdade pessoal e da autoexpressividade. Isso não quer dizer que não possa haver uma competição, pois, tanto no jogo, como na arte marcial e na vida cotidiana, estamos rodeados de situações em que a competição aparece como impulsionadora da atividade. Mas esta competição é orgânica e funciona como um estímulo para os envolvidos. Nesse sentido, Spolin (2003, p. 10), explica que este tipo de competição "é a estimulação crescente que aparece na medida em que os problemas são resolvidos e que outros mais desafiantes lhe são “colocados". Neste caso, "os companheiros de jogo são necessários e bem recebidos".

Por fim, no que diz respeito à presença de observadores nas artes aqui pesquisadas, encontramos algumas variações que merecem ser apontadas. Na "capoeira" a possibilidade de haver observadores pode ser claramente percebida em duas instâncias: as pessoas que compõem a roda que cerca os jogadores e as pessoas que observam a roda. Neste caso, temos dois tipos de observadores, estando um envolvido diretamente no jogo e o outro contribuindo para a instauração da atmosfera do jogo. $\mathrm{O}$ primeiro deve estar com um grau de atenção alto, pois a qualquer momento pode se colocar para jogar estabelecendo dupla com um parceiro, comprando jogo ou sendo 
chamado para um desafio. O segundo, por sua vez, apesar de ficar mais distante, ocupando uma posição mais passiva na medida em que não tem responsabilidade direta sobre o que está acontecendo na roda, tem participação importante na manutenção da energia do jogo. Percebe-se, dessa forma que na "capoeira", a troca entre quem está jogando e quem está observando é bastante dinâmica. Existe entre observadores e jogadores um envolvimento pessoal e intenso e uma estimulação genuína por meio da afetação sensorial pelo que está se passando na roda. Esta liberdade pessoal para experimentar que pode ser observada na atitude dos jogadores está presente também nos atos de quem compõe a roda ou simplesmente assiste, pois cada um deles está sendo movido de forma muito pessoal. Trata-se, portanto, de um acontecimento cuja concepção estética e cultural propõe um envolvimento com os observadores que vai além de uma simples combinação ou marcação como "Nós fazemos e vocês assistem". A dinâmica de um evento como este provoca, instiga e afeta de forma total os presentes, estando eles inseridos mais ativamente na roda ou não.

Já no "aikido", a posição do observador não é tão bem definida, uma vez que depende de cada momento e de cada evento. Em caso de demonstrações públicas, por exemplo, o observador se coloca como uma plateia convencional, assistindo e podendo se envolver emocionalmente, com maior ou menor intensidade, sem interferir no andamento do que está sendo realizado. Já em exames de troca de graduação, alguns observadores são simples espectadores que não interferem diretamente no evento, enquanto outros são os examinadores com a função de analisar o desempenho dos aikidoistas que estão performando. Durante um treino, diferentemente, as funções dos observadores e dos jogadores são trocados de forma bastante dinâmica, uma vez que as duplas são trocadas constantemente. Apreende-se, portanto que, de forma geral, no "aikido" existe uma rigidez maior em relação à posição de quem assiste em comparação com a "capoeira" que permite uma relação mais dinâmica e intensa entre jogador e observador.

Apreende-se, portanto, diante de tudo o que foi exposto acerca da presença dos elementos lúdicos na prática do "aikido", da "capoeira" e do teatro que, visando à concepção de um treinamento que auxilie o trabalho do ator de forma ampla em sua criação cênica, muitas conexões podem ser realizadas entre as artes cênicas e marciais de modo que esta última fomente e potencialize a primeira, oferecendo recursos inúmeros, tanto no que diz respeito à preparação individual como à prática coletiva. Tanto o "aikido" como a "capoeira" possuem elementos que permitem desenvolver a 
interação, criação, adaptação, descontração, coordenação, disponibilidade corporal e concentração que podem ser aproveitados para a elaboração de procedimentos que aprimorem a prática cênica.

Pensando especificamente na relação dos aspectos apontados com esta etapa do trabalho, a improvisação foi utilizada como forma de aprofundar o autoconhecimento corporal e desenvolver o potencial de cada ator, tendo como base o material experimentado no início do treinamento. Além deste desenvolvimento pessoal, as improvisações também serviram como forma de levantar material artístico a partir do trabalho criativo dos atores para a elaboração de uma dramaturgia. Isto porque o improviso permite a experimentação e a exteriorização das subjetividades, livre da zona de acerto e erro, justamente porque neste momento nada está definido e tudo é possível. Esta liberdade, norteada por algumas regras definidas, ajuda a instaurar uma atmosfera mais propícia para a criação.

Além disso, convém reforçar que, neste trabalho interseccionamos os termos "jogo" e "improviso" porque, conforme procuramos explicar ao longo deste capítulo, em ambas atividades nos deparamos com desenvolvimento de habilidades semelhantes como vivência espontânea e pessoal, muitas vezes em grupo, através de algumas regras previamente estabelecidas, buscando soluções de tensões por meio de desenvolvimento de estratégias, de criatividade e inventividade. Em razão deste entendimento, para esta pesquisa sempre que nos referirmos ao improviso a estamos considerando também como um jogo e vice-versa.

Assim, nesta fase do treinamento procuramos, por meio dos improvisos/jogos, colocar em prática tudo o que foi experienciado e aprendido desde o início do processo, de modo que novas conexões e inter-relações fossem surgindo, com liberdade e descontração. A seguir trataremos mais especificamente da prática com os atores.

\subsubsection{Improviso individual}

Até o momento falamos de todas as características presentes nas atividades lúdicas que podem auxiliar o trabalho do ator. Portanto, nesta fase, estando os atores mais familiarizados com o repertório novo em virtude do período de estudos no início do treinamento, focou-se nesta etapa em improvisos/jogos norteados pelos princípios selecionados. Embora tenha sido enfatizado o aspecto relacional e de grupo presente nesse tipo de atividade, existe muitos exemplos em que ela é realizada por uma única 
pessoa. Nestes casos, muitas vezes a relação se dá com algo e não alguém, como um objeto ou uma música. Pensando na organização do treinamento, focamos em alguns momentos na improviso/jogo individual, e colocamos como parte desse jogo elementos extraídos do "aikido" e da "capoeira" como músicas, bastão, partes do corpo etc. A intenção destes procedimentos era o de que o ator ampliasse a consciência sobre seu próprio trabalho e que estes elementos externos que fossem introduzidos, servissem como estímulos e apoios para suas descobertas, proporcionando elaboração de estratégias, soluções para questões colocadas, criação de possibilidades em torno de um foco, dentre outros. Com estas propostas buscou-se que os atores ficassem mais livres e disponíveis para experimentar, descobrindo caminhos criativos novos a partir do repertório aprendido.

Decidimos focar inicialmente em uma abordagem individual do repertório experimentado porque observei uma dificuldade dos atores no começo do treinamento em criar a relação com o parceiro. O grau de fluidez que foi sendo conquistado durante as experimentações individuais, era perdido quando juntávamos os atores em duplas para as improvisações. Concluí que os atores precisavam de um período de prática trabalhando a partir de si mesmos e de seu próprio corpo para então inserir outras informações.

No que diz respeito ao uso de elementos externos, a relação com a música nesta etapa foi a mais bem aproveitada pelos atores, de modo que eles se sentiam verdadeiramente mais estimulados. Por esta razão recorremos a diversas músicas e sons tanto do universo da "capoeira" quanto japonês, para que os atores se sentissem mais sensibilizados. Por consequência, algumas dessas sonoridades passaram a integrar a dramaturgia.

Outro recurso utilizado para auxiliar os improvisos de modo que os atores ficassem mais livres, disponíveis, estimulados e criativos foi o uso da imaginação. Assim, foram elaboradas conduções ao longo do processo que recorriam na maior parte das vezes ao poder imaginativo dos atores. $\mathrm{O}$ objetivo dessas conduções era tornar mais fácil o desenvolvimento dos princípios selecionados e servissem de fato como material para a criação da dramaturgia. Como exemplo, podemos citar a ideia da sinuosidade do movimento encontrada na ginga da "capoeira". Para tornar mais fácil a abordagem corporal dessa técnica, utilizamos a ideia da cobra e foi solicitado que os atores imaginassem que suas colunas fosse uma cobra. Nesta improvisação, ao trazer essa imagem, o corpo todo do ator reagia e se adaptava se movimentando pelo espaço como 
se estivessem corporificando esta cobra imaginária. O mesmo processo aconteceu com o "aikido". Como ilustração, podemos citar o princípio da espiralidade. A fim de aproximar este princípio dos atores, pedi que eles imaginassem que estavam desenhando círculos e esferas no espaço com o próprio corpo, como se o espaço fosse uma tela de pintura e o corpo todo fosse o pincel. Este "desenho" criado por eles durante a improvisação poderia ser amplo de modo a ocupar a "tela" toda ou poderia ser discreto ocupando espaços mais reduzidos dessa "tela". A ideia de criar desenhos de diversos tamanhos na tela possibilitava um uso bastante diversificado das partes do corpo. Convém ressaltar que todos os estímulos imaginativos propostos estavam relacionados ao contexto das artes marciais mencionadas justamente para que os atores conseguissem adentrar neste processo da forma mais inteira possível.

Seguem abaixo descritas algumas dessas conduções. No vídeo anexo pode-se assistir um trecho destas improvisações.

a) A partir do "aikido"

1) desloquem-se com os joelhos levemente flexionados e com as pernas afastadas, movimentando-se circularmente, como se quisessem desenhar círculos e espirais no espaço com o corpo. Imaginem que o espaço é uma tela em branco e o corpo é o pincel ou lápis;

2) criem desenhos no chão com o deslocamento de vocês. Como vocês têm que desenhar no chão, os pés devem deslizar por ele e nunca perder contato. Este desenho pode ser uma linha fina ou pode ser um traçado mais grosso;

3) Imaginem que com os movimentos, vocês estão trazendo a energia que está no espaço para o centro de vocês e devolvendo em seguida, em uma troca constante;

4) desloquem-se apenas em nível baixo, aproveitando principalmente o contato dos joelhos com o chão e o apoio das mãos. Imaginem que tem um teto logo acima de vocês que impede que vocês fiquem em pé;

5) criem esferas com o corpo, a partir de torções que se iniciam em uma parte e reverberam para o restante do corpo. Imaginem que alguém está torcendo uma parte do 
corpo de vocês até o limite/ Imaginem que os desenhos criados no espaço estão sendo copiados pelo corpo de vocês;

6) Imaginem que tem um motor no quadril de vocês e este motor conduz o corpo todo;

7) dancem como se o movimento estivesse fluindo da extremidade (braços, cabeça, pés, mãos...) para o centro (quadril). Imaginem que alguém está puxando as extremidades do corpo de vocês;

8) vão do nível alto a baixo e vice-versa, construindo uma longa trajetória de curvas e espirais no espaço. O objetivo é não chegar rapidamente no nível alto e nem no baixo. Imaginem como se estivessem dentro de um cano e só pudessem se descolar dentro desse espaço limitado e de forma circular;

9) inspirem como preparação para o movimento e expirem para a realização do movimento. Imaginem que na inspiração, uma bola de luz está sendo criada em frente o seu hara. Os braços devem ajudar a concentrar esta luz e espalhá-la pelo espaço na expiração;

10) dancem como se alguém estivesse conduzindo vocês para baixo, mas vocês precisassem subir. Em um momento vocês cedem e vão para o chão. Mas a improvisação não acaba quando chegam ao chão, pois a pressão continua sobre vocês. Como reagir a isso?;

11) dancem indo de leve instabilidade para a total desestabilidade com a queda. Imaginem que alguém está provocando esta instabilidade, empurrando ou puxando vocês.

b) Da "capoeira":

1) desloquem-se sobre 3 ou quatro apoios, mas sem encostar os joelhos e o quadril no chão. Imaginem-se 
bichos que precisam se deslocar dessa forma, mas são ao mesmo tempo ágeis;

2) Imaginem que tem que se deslocar em nível baixo porque não podem se expor e tem que se movimentar sorrateira, silenciosa e discretamente;

3) movimentem-se como se o corpo todo precisasse se recolher antes de expandir. No recolhimento inspire e na expansão expire. Imaginem que existe uma concentração de energia quando se recolhe e uma explosão quando se expande. Deixem esse movimento o mais contínuo possível;

4) movimentem-se apenas sobre o metatarso, contínua e fluidamente. Imaginem que o chão os ajuda a impulsionar o movimento para todas as direções e não apenas para cima;

5) movimentem-se e desloquem-se aproveitando a sinuosidade da cobra. Imaginem que a coluna de vocês é uma cobra;

6) movimentem-se pensando em desenhar círculos no espaço com o corpo todo, especialmente braços, quadril, mãos e pernas;

7) movimentem-se como se estivessem dentro de um círculo e não pudessem sair dele;

8) movimentem-se como se fossem um dos instrumentos da música que estão ouvindo. A partir do meu comando troquem o instrumento. Por fim, foquem na música como um todo. Usem a letra para estimulá-los;

9) criem desenhos no solo a partir dos movimentos dos pés e das mãos, deixando marcas maiores ou menores: pontos, retas e círculos;

10) desloquem-se pelo espaço mudando de direção constantemente e subitamente, aproveitando todos o níveis do espaço. Imaginem que tem algo vindo em sua direção e precisam contornar. 
Sobre este treinamento, a atriz Helena Semedo comentou:

Quanto mais exercito durante os ensaios, mais percebo que vou encontrando outras formas de me movimentar, de posicionar meu corpo, mudando meus padrões iniciais. Dessa forma, quando vou para a improvisação, consigo cada vez mais manter este novo "corpo" ao invés de voltar sem perceber para o que já era comum para mim.

No decorrer das improvisações, as sensações eram despertadas trazendo à tona imagens mentais, memórias e emoções que eram anotadas por nós para futura criação cênica. Percebe-se, dessa forma, que destas improvisações, foram aproveitados materiais produzidos tanto de natureza física quanto psíquica. Algumas impressões anotadas por eles durante improvisações conduzidas a partir dos princípios extraídos do "aikido" foram: acolhimento - com o uso da força centrífuga-, rejeição - uso da força centrípeta-, angústia - torção pesada-, sensualidade - torção leve-, comunicação x não comunicação, solidão e autoacolhimento - movimentos que vão em direção ao centro do corpo-, imposição, subjugação, acolhimento do outro, cuidado, amor, conquista, condução, orientação e cumplicidade. Algumas impressões surgidas das improvisações tendo como estopim os princípios extraídos da "capoeira" foram: embate de forças, sedução, disputa de espaço e disputa de poder, subjugação, brincadeira, opressão, traição, cumplicidade, conquista e estado de alerta. Estas impressões pessoais os conduziam nas improvisações estimulando a criatividade e despertando o corpo de forma inteira. Todo esse material contribuiu para a construção da dramaturgia.

Durante todo esse processo também me coloquei como atriz e experimentei os mesmos procedimentos que os demais atores. Dessa forma, todas as etapas vivenciadas por eles foram vivenciadas também por mim, com a diferença de que eu possuía mais experiência nas artes marciais em questão. Assim, as improvisações individuais foram também importantes para que eu pudesse investigar variações e criar a partir das técnicas selecionadas, pois apesar de eu ter mais segurança que os atores na realização das técnicas, precisava descobrir caminhos para transformá-las em material cênico. Participar também como atriz, me possibilitou ter uma compreensão melhor do processo, me trazendo mais ideias e soluções para o encaminhamento com os atores, pois o olhar de fora nos mobiliza de forma muito diversa de quando estamos efetivamente inseridos na prática.

De todas essas vivências, depois de um período apenas com improvisações livres, sem temas específicos, me senti motivada a experimentar o monólogo "ser ou 
não ser" de Hamlet a partir dos elementos do "aikido" e da "capoeira". De tudo o que experimentei nas improvisações, os elementos da "capoeira" me pareceram mais orgânicos e adequados à circunstância do monólogo. Este entendimento se deu pelo uso do corpo, por isso não consegui racionalmente chegar a uma conclusão objetiva de porque seria melhor me apoiar na "capoeira" para este momento. Em razão desta sensação que ficou muito forte em mim durante as improvisações, resolvi investir nessa escolha e concebi uma cena inspirada nos seguintes elementos: música intercalada ao texto, volta ao mundo, som de percussão, movimento de pernas e braços, ginga e uso do nível baixo sobre dois e três apoios. Assim, parte do texto de Shakespeare dialogou com alguns trechos da música Lapinha de Baden Pawell para materializar e corporificar o conflito interno vivenciado neste momento por Hamlet. A progressão rítmica jo ha kyu foi aqui observada especialmente na variação da velocidade com o uso da volta ao mundo, da repetição de movimentos e de textos e do som de percussão, que neste caso foi performado no próprio corpo.

A cena se inicia com a atriz fazendo a volta ao mundo cantando repetidamente: “Quando eu morrer me enterre...". Inicia-se então uma partitura física criada a partir do texto de Shakespeare ao som do berimbau executado por Jefferson Mathias. Segue-se então o texto adaptado do monólogo "ser ou não ser" intercalado com a música Lapinha de Baden powell:

Vai meu lamento vai contar,

Toda a tristeza de viver.

Ai a verdade sempre trai e às vezes traz um mal a mais.

Ser ou não ser, eis a questão.

O que é mais nobre pra alma?

Suportar os dardos e arremessos do fardo sempre adversos? Ou armarse contra um mar de desventuras e dar-lhes fim tentando resistir-lhes? Morrer, dormir, mais nada. Imaginar que o sono põe remate aos sofrimentos do coração é razão para almejar-se.

Ai, só me fez dilacerar, ver tanta gente se entregar.

Morrer dormir, talvez sonhar. Mas é aí que bate o ponto. O não sabermos que sonhos poderão trazer o sono da morte, quando ao fim, desenrolarmos toda a meada mortal nos põe suspensos. É essa ideia que torna verdadeira calamidade a vida assim tão longa.

Sai minha mágoa sai de mim.

Há tanto coração ruim.

Ai é tão desesperador, o amor perder pro desamor.

Ah, tanto erro eu vi, lutei

E como perdedor gritei!

E quem suportaria o escárnio e os golpes do mundo, a injustiça dos mais fortes, os maus tratos dos tolos, a agonia do amor não correspondido, as leis amorosas, a implicância dos chefes, o desprezo da inépcia contra o mérito paciente, se estivesse em suas mãos, obter 
sossego com um punhal. Que fardos levaria nessa vida cansada a suar, gemendo se não por ter algo após a morte. Terra desconhecida de onde ninguém jamais voltou. Que nos inibe a vontade, fazendo com que aceitemos os males conhecidos, sem buscarmos refúgio noutros males ignorados. E assim, a reflexão faz de todos nós covardes.

Seguem abaixo algumas imagens da cena. No DVD anexo pode-se assistir a cena no estado em que se encontrava até a finalização da tese. Cabe esclarecer ainda que todas as cenas que estão aqui apresentadas continuaram a ser aprofundadas até o momento da defesa.

Imagens de 55 a 59: resultados cênicos
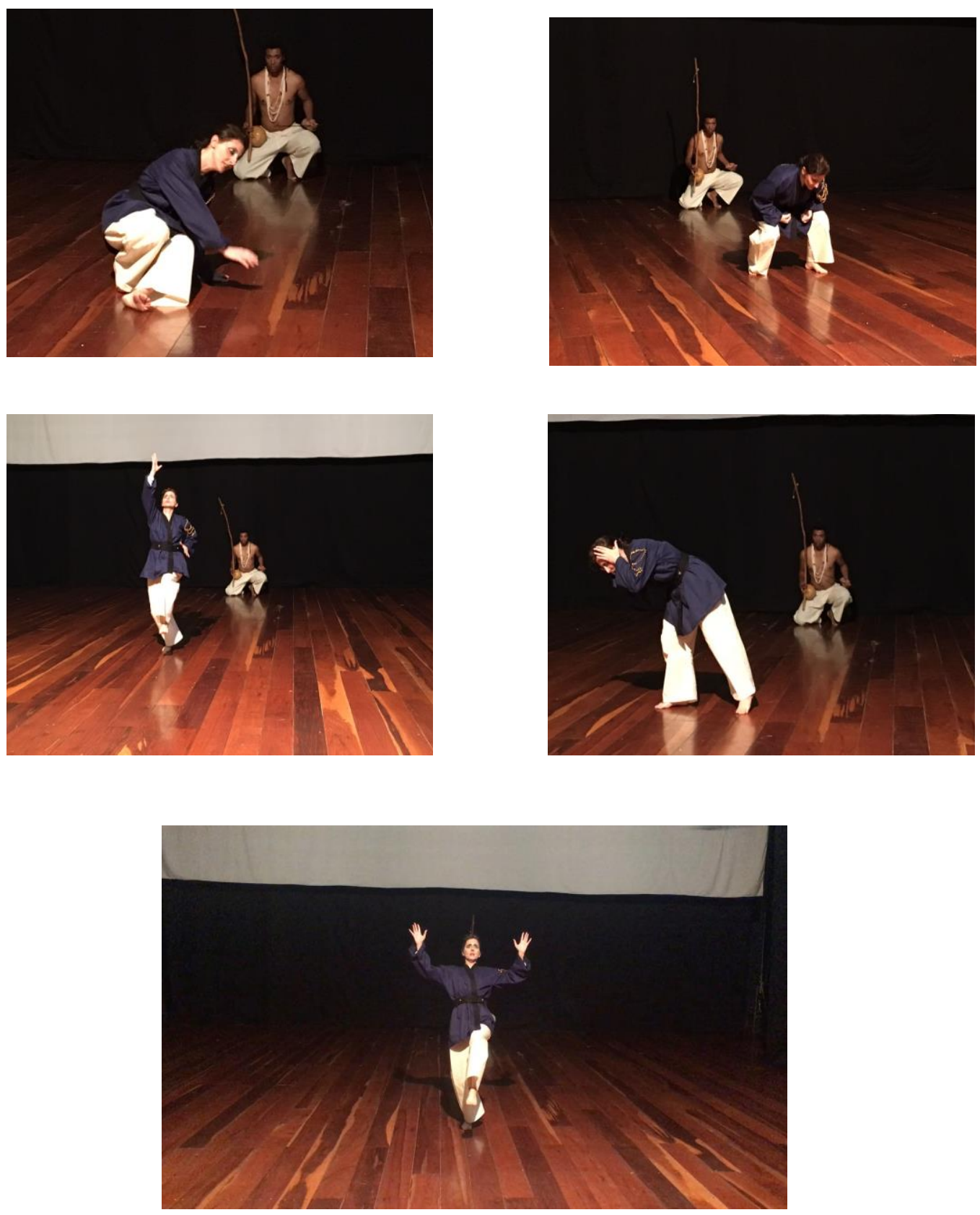

Fontes: arquivo do autor. 
Outro exemplo de improvisação individual e que resultou em dramaturgia foi a cena do Rei Cláudio após a encenação do assassinato. Esta cena foi performada pelo ator Ignacio Muñoz. Neste momento, o Rei, impactado emocionalmente com a apresentação teatral arquitetada pelo enteado/sobrinho, levanta-se e se retira no recinto. Esta cena foi criada inspirada nas falas de Hamlet e Guildenstern e do próprio Cláudio, que seguem transcritas abaixo:

I.

GUILDENSTERN: Se retirou, como viu, e está lá dentro num horrível destempero.

HAMLET: Bebeu demais, senhor?

GUILDENSTERN: Não senhor, destempero de cólera.

II.

CLÁUDIO: Meu delito é fétido. Pesa sobre ele a maldição mais velha, a maldição primeira: matar um irmão. Se esta maldita mão de sangue fraterno se cobrisse, não haveria chuva suficiente no céu para deixa-la como neve? Que forma de oração pode servir meu indulto? É possível ser perdoado retendo os bens do crime? E, então, que resta? Ver o que pode o arrependimento? O que não pode? Mas o que pode quando não conseguimos nos arrepender? Que lamentável estado! Peito negro como a morte! Oh, alma cheia de visgo, cuja luta por ser livre ainda a embaraça mais. Socorro, anjos! Coração de tendões de aço fica suave como carne tenra de recém-nascido. Tudo pode sair bem.

Para a criação deste momento o ator Ignácio Muñoz recorreu especialmente aos princípios presentes nos movimentos do $u k e$ que são: torção pesada - seguindo conceito de Laban sobre os fatores de movimento-, desequilíbrio/instabilidade, uso do nível baixo e queda. Isto porque se identificou uma conexão entre o estado emocional do Rei e a posição da pessoa que é contragolpeada na prática do "aikido". Concluiu-se que ambos estão em uma situação desprivilegiada no sentido de estarem a mercê de alguém e sofrendo as consequências de ações alheias. No caso do $u k e$ essas ações são os golpes do nage e no caso do Rei Cláudio é a encenação sobre o assassinato do Rei. Estabelecemos aqui, portanto, uma ponte entre os aspectos físicos do uke e os emocionais do personagem, retomando a relação entre os elementos psicofísicos do corpo, já discutidas ao longo desse trabalho. A progressão gradual indicada pelo 
princípio $J o$ ha kyu foi aqui fisicalizada por meio da variação da tensão na realização das torções que foram de leves a pesadas até o desequilíbrio e a queda. Com a queda, houve o recomeço da progressão até a saída do Rei de cena.

Sobre esta experiência o ator comentou:

\begin{abstract}
Quando comecei a usar os princípios do "aikido" para criação dramatúrgica, senti muita dificuldade de conectar o que estava treinando com os movimentos que estava fazendo e o texto de Shakespeare. Com o passar do tempo, tudo começou a ficar mais claro pra mim. A prática do "aikido" nos ensaios, com alongamentos e exercícios específicos facilitou a preparação física para a cena e estimulou minha criatividade. No trabalho com o Rei Claúdio utilizei muitas referências do nage para criar uma postura altiva, de domínio e autoridade. Mas no caso do monólogo após o teatro experimentei outra qualidade de movimento, tendo como referência o uke. As torções e os desequilíbrios do uke me ajudaram a trazer para meu corpo as angústias e conflitos que o personagem estava vivenciando naquele momento. Estes elementos me ajudaram a entrar nas circunstâncias propostas por Shakespeare, fazendo com que eu ficasse mais criativo e meus movimentos mais orgânicos. Consegui também conectar o texto ao que estava fazendo. Um foi ajudando o outro.
\end{abstract}

Adiante seguem algumas imagens sobre a cena que podem ser assistidas no DVD anexado.

Imagens de 60 a 63: resultados cênicos


Fontes: arquivo do autor. 
A respeito do processo de criação convém esclarecer um procedimento que foi utilizado por nós tanto nas improvisações individuais como em dupla ou grupo. Todas as improvisações produziam materiais - movimentos, falas, relações etc.- que foram, depois de finalizada a prática, avaliadas pelo grupo. De tudo que se produziu, uma parte foi selecionada por nós, visando a criação de partituras físicas. A qualidade da precisão destas partituras variou de acordo com a cena no sentido de que, enquanto algumas foram definidas de modo que os desenhos de movimentos criados fossem totalmente dominados pelo ator, podendo ser repetidos sem perder sua organicidade, em outras, a precisão estava na qualidade do fazer do movimento e da relação, sem que houvesse uma sequência absolutamente marcada pelos atores, podendo sofrer alterações durante sua realização. Estas últimas ficavam em um estado intermediário entre improviso e partitura física. Estas escolhas foram feitas durante o processo a partir do que julgávamos mais orgânico no momento.

Percebe-se, portanto que, na investigação prática, objetivou-se fazer com que os atores, apropriando-se dos elementos técnicos aprendidos e compreendendo as qualidades que envolvem os movimentos destas duas artes marciais, pudessem experimentar a transposição do corpo cotidiano para o corpo cênico e criar ações e movimentos ancorados nos princípios extraídos do "aikido" e da "capoeira".

Pelo que foi apresentado, procuramos deixar claro que o treinamento, como um todo, envolveu os seguintes aspectos: tornar o corpo mais disponível para a ação, ampliar repertório e possibilitar a apropriação do que foi aprendido de modo que criasse a partir disso, em vez de se preocupar simplesmente em reproduzir informações recebidas. Em outras palavras pode-se dizer que a busca não foi o aprimoramento das técnicas das duas artes marciais ora estudadas, mas a ampliação de possibilidades criativas, de modo que o ator, ao se relacionar com os elementos e princípios extraídos destas artes, pudessem chegar a um corpo cênico e um estado criativo mais potente.

\subsubsection{A relação}

Conforme procuramos apontar, esta pesquisa não focou apenas o trabalho individual do ator, mas também a conexão entre eles, uma vez que ambas as artes marciais aqui estudadas são essencialmente relacionais. Para auxiliar esta compreensão, expusemos no primeiro capítulo que o corpo não pode ser entendido desconectado do que o cerca, mas, ao contrário, ele vai se definindo a partir das relações que estabelece. A fim de aprofundar esta temática, neste capítulo, procuraremos enfocar a noção de 
relação como preparação para o trabalho cênico e recurso criativo e, de modo mais específico, a relação construída entre os parceiros de cena, inspirados nos elementos proporcionados pelo "aikido" e pela "capoeira".

Se entendemos o ser humano a partir das relações que estabelece, é natural que entendamos também o artista como um ser que concebe sua arte a partir das relações nas quais se envolve. Assim, acreditamos que quando o artista cria, o faz a partir de si mesmo, sendo este "si mesmo" fruto do contato com as pessoas e coisas que o circundam. Acerca destas relações que os seres humanos estabelecem ao longo da vida, Noe, 2009, aponta que, para entendermos a mente de alguém se faz necessário compreender o ambiente em que essa pessoa vive, as relações que ela estabelece e as coisas que faz, uma vez que a percepção acontece na ação. Desde o nascimento, relacionar-se com outras pessoas é fundamental. Noe lembra, por exemplo, que um bebê mama no peito da mãe, não somente para satisfazer a necessidade alimentar, mas também pela necessidade do toque, da proximidade com o outro. Esta relação não é de apenas uma via, ou seja, não se trata apenas do bebê em relação à mãe, mas também da mãe em relação ao bebê, relações estas que não se rompem com o amadurecimento da pessoa, mas que vão se transformando com o tempo. Desenvolvendo essa ideia, Noe (2009, p. 33) explica que "como o bebê na relação com sua mãe, nós estamos envolvidos um com o outro. É nossa coabitação conjunta que assegura nossa consciência viva para cada um. Nós vivemos e trabalhamos juntos"32. Somos, portanto, frutos das relações que estabelecemos ao longo de nossas vidas.

Assim como Noe, diversos outros filósofos desenvolveram ao longo do tempo teorias procurando compreender o funcionamento do corpo humano e encontraram na integração e na afetação recíproca das partes que formam o corpo e nas relações entre os seres humanos algumas respostas para seus questionamentos. Barush Spinoza é um destes filósofos que buscou nas afetações de um ser para o outro ser algumas pistas sobre o ser humano e sua relação com o mundo. Acerca disso Spinoza, 2009, postulou o seguinte:

Segunda Parte: Postulado: 1. O corpo humano compõe-se de muitos indivíduos (de natureza diferente), cada um dos quais é também

32. "Like the baby in relation to her mother, we are involved with each other. It is our joint cohabitation that secures our living consciousness for each other. We live and work together.” (NOE, 2009, p. 33) 
altamente composto. 2. Dos indivíduos de que se compõe o corpo humano, alguns são fluidos, outros, moles, e outros, enfim, duros. 3. Os indivíduos que compõem o corpo humano e, consequentemente, o próprio corpo humano, são afetados pelos corpos exteriores de muitas maneiras. (...) 6. O corpo humano pode mover e arranjar os corpos exteriores de muitas maneiras. (SPINOZA, 2009)

Neste trecho Spinoza argumenta que a complexidade que envolve o ser humano começa desde a sua formação fisiológica mais interna, com a inter-relação entre as partes que o compõem de naturezas distintas, até os encontros que vai vivenciando ao longo de sua vida. Este filósofo explica ainda que o corpo, resultado da união da mente, do físico e do espírito, pode ser afetado por muitas maneiras, maneiras estas que variam de acordo com a natureza do corpo afetado e do corpo que o afeta. Portanto, sempre que houver um encontro entre dois corpos, a qualidade deste encontro será conforme a particularidade de cada corpo e a forma destas particularidades interagirem entre si.

Spinoza completa ainda que "se o corpo humano foi, uma vez, afetado, simultaneamente, por dois ou mais corpos, sempre que, mais tarde, a mente imaginar um desses corpos, imediatamente se recordará também dos outros" (SPINOZA, 2009, Segunda Parte, Proposição 18). Este pensador traz, portanto, para a discussão outro elemento já abordado anteriormente que é a potencialidade imaginativa do ser humano, a memória corporal e a capacidade de associações de vivências passadas com o presente. Podemos dizer assim que os encontros geram conhecimentos, ideias e imagens e, por consequência, quanto mais afetações e mais modificações decorrentes do contato com outros corpos, mais ideias e mais conhecimentos serão produzidos.

Dando seguimento a seu raciocínio Spinoza, 2009, apresenta outra proposição que trata da maximização das afetações e dos encontros "bons" para o ser humano. Coloca este filósofo que:

4 Parte. Proposição 38. É útil ao homem aquilo que dispõe o seu corpo o poder ser afetado de muitas maneiras, ou que o torna capaz de afetar de muitas maneiras os corpos exteriores; e é tanto mais útil quanto mais torna o corpo humano capaz de ser afetado e de afetar os outros corpos de muitas maneiras. E, inversamente, é nocivo aquilo que torna o corpo menos capaz disso. (SPINOZA, 2009)

Ele defende, por conseguinte, que é benéfico para os seres humanos tudo aquilo que faz com que seus corpos mantenham sua plenitude e sua potencialidade de 
afetações, respeitando as particularidades de formação de cada um. Assim, todos os encontros que fazem com que a vida ganhe força são considerados alegres. Por outro lado, tudo o que destrói esse processo, fazendo com que os corpos percam essas capacidades, é considerado nocivo. Entendemos ainda que Spinoza defende que a potencialidade do corpo é infinita e que não fazemos ideia do que o corpo é capaz. Temos assim que, o ser humano, ao criar relações propícias para o desenvolvimento de seu potencial, ou seja, ao se colocar diante de encontros alegres, pode se deparar com resultados imprevisíveis.

Estabelecendo um paralelo entre o apresentado por Spinoza e o que discutimos sobre os jogos e improvisações, tanto melhor se desenvolverão essas atividades, quanto mais livre, disponível e motivado estiver o jogador/improvisador. Por esta razão, acreditamos que seja importante que a organização e a condução de uma improvisação aconteçam de forma que este encontro seja potencializado e que todos os envolvidos se sintam impulsionados a criar e a agir.

Acrescente-se ainda que "o corpo espinoziano não está, e nunca estará, completamente formado, pois que é permanentemente informado pelo mundo (...) inacabável, provisório, parcial, participante - está, incessantemente, não apenas se transformando, mas sendo gerado" (FABIÃO, 2010, p. 238). E essa transformação incessante está diretamente conectada à ideia de corporeidade como este fenômeno que se realiza no corpo, ligando-o a todas as dimensões que o circunda.

Pensando na importância de entender o homem como um ser que se relaciona e que passa por um processo de formação durante toda a sua vida, formação esta provocada pela interação com tudo e todos que interage, é natural que entendamos a importância desse fenômeno também no trabalho do ator. Estas interações, entretanto, podem ser potencializadas de forma a tornar mais fértil o trabalho em cena. Assim, quando o ator se propõe a estabelecer relações em uma improvisação com alguém, precisa efetivamente percebê-lo e agir a partir dele, ou seja, para que este encontro seja fértil é preciso também escutá-lo ao invés de só falar. Esta escuta e fala as quais nos referimos não trata somente da habilidade auditiva e vocal de dizer e de escutar, mas se refere a uma comunicação mais ampla que passa pelo corpo todo. Assim, entendemos que o ator em cena precisa tanto propor como perceber o que é proposto e se relacionar com isso, pois sem esta via de mão dupla, falando metaforicamente, a troca não se efetiva e a relação fica empobrecida. Estabelecendo um paralelo com Spinoza, o 
encontro será útil e bom se estas mútuas afetações potencializarem todos os corpos que estão em relação.

Fabião, tratando deste corpo relacionável e de sua conexão com o trabalho do ator, expõe que:

Um corpo é sempre uma multidão de relações e, como tal, está permanentemente deflagrando relações. Corpo em relação com corpo forma corpo. $\mathrm{O}$ entre-lugar da presença é no nosso corpo o que não está em nós.

Para ativar circuitos relacionais, o ator deve trabalhar tanto no sentido de aguçar sua criatividade como sua receptividade. Geralmente a criatividade é privilegiada em detrimento da receptividade, a força criativa em detrimento do poder receptivo. Estamos mais habituados a agir do que a distensionar, a ponto de sermos agidos; somos treinados para criar e executar movimento, não para ressoar impulso; (...) A busca por um corpo conectivo, atento e presente é justamente a busca por um corpo receptivo. A receptividade é essencial para que o ator possa incorporar factualmente e não apenas intelectualmente a presença do outro. $(2010$, p. 323)

Fabião, neste trecho fala da percepção do outro em sua integralidade no momento presente. A isso chamo também de comunhão entre duas pessoas que estão realmente conectadas em um determinado momento, sem a pretensão de impor ao outro, mas de propor e de receber na medida em que o diálogo corporal vai se dando. Comunhão é um termo usado por diversos pesquisadores de teatro como Stanislavski que buscam por meio de um treinamento específico alcançar essa comunicação plena entre os atores.

Fabião aponta neste trecho a essencialidade de estar aberto e disponível para perceber o outro, se afetando por ele e reagindo a partir disso. Quando o ator se coloca também em estado de receptividade não está sendo passivo, mas está abrindo novos caminhos para novas descobertas. É este estado que encontramos entre dois atores jogando, improvisando. Nessa interação, dando e recebendo, percebemos a liberdade pessoal e espontaneidade em conexão com a imprevisibilidade surgida pela intervenção do outro.

Pensando na "capoeira" que já traz a proposta de jogo em sua essência, o que pressupõe a necessidade de interação entre os participantes, e no "aikido", que propõe a realização de movimentos a partir do impulso promovido pelo parceiro, percebemos que estas duas artes marciais têm como fundamento a necessidade desta "escuta" integral e plena com o corpo todo durante a prática e da receptividade do outro para que a atividade se desenvolva harmonicamente. É importante lembrar que consideramos neste 
trabalho harmonia como o diálogo e a interação entre os opostos, como ying e yang, leve e pesado, agressivo e suave, alto e baixo e assim por diante. No "aikido", o aikidoista não deve se preocupar em estabelecer combinações com o parceiro, pois, ambos precisam estar livres para que haja a interação. Se o uke desferir um soco contra o nage e, ao ter esse soco "absorvido" pelo movimento do nage, não se colocar disponível nesse momento para se relacionar com esta nova proposta, provavelmente se lesionará fisicamente. Entende-se, portanto, que, para esta arte marcial japonesa, a completude só se dá quando existe o encontro, a conexão entre os parceiros e a troca de energia de um para outro, afetando-se recíproca e diretamente. Da mesma forma que o "aikido", a "capoeira" tem seu foco na relação entre os parceiros, uma vez que se completa no jogo durante a roda estimulado por cantigas, toques e, em alguns grupos, com acompanhamento de palmas dos participantes. O que acontece dentro da roda, está diretamente ligado à disponibilidade dos praticantes que estão jogando e ao que se realiza em volta. Se um jogador unicamente se preocupar em agir deixando de prestar atenção ao parceiro, provavelmente não terá tempo de se preparar para desviar de um chute e preparar uma defesa ou contra-ataque. Neste estado o jogador também não conseguirá se relacionar com o parceiro e com a música executada pela roda e quebrará a fluidez e a sintonia tão caras a esta arte marcial. Nesta interação um efetivo diálogo corporal acontece entre os dois, sem combinações e com uma efetiva presença e sintonia entre os parceiros. Em outras palavras podemos dizer que, quando se está jogando, o ideal é que o capoeirista não programe seus movimentos, que não tente se impor ao outro e que não deixe seus pensamentos se ocuparem com assuntos estranhos a esse processo, mas que, ao contrário, deixe toda a atenção voltada para o momento presente do jogo e para o parceiro, procurando "dialogar corporalmente" a partir do que estiver se desenvolvendo naquele instante. Nestes dois casos, o segredo é o corpo conectivo e relacionável a que menciona Fabião, 2010, em que o praticante não se preocupa apenas em agir, mas também em receber a proposta do parceiro durante o jogo.

Considerando todas estas qualidades relacionais que o "aikido" e "capoeira" têm, procuramos aproveitá-las para a potencialização do trabalho criativo e expressivo do ator para que ele pudesse exercer a tão mencionada liberdade pessoal reforçada por Spolin, 2003, durante uma improvisação, ao mesmo tempo em que contribuía para que o outro também se expressasse livremente. Se um ator se sente recebido e percebido pelo outro, ao invés de ser ignorado por ele como se estivessem em uma disputa de 
quem faz mais, o diálogo entre eles realmente acontece e se estimulam mutuamente. Neste estado, todos se sentem mais relaxados e confortáveis, aproveitando e experimentando o que cada momento pode oferecer. Podemos identificar neste tipo de relação a noção de encontros bons/alegres mencionada por Spinoza, quando a afetação do outro ajuda a construir e a desenvolver o próprio potencial. Não vemos neste caso uma destruição de um ator pelo outro, mas a construção de uma obra artística que não tem um autor, mas uma multiplicidade de autoria que dá uma riqueza maior à obra concebida.

Por consequência, pensando nestes encontros que tiveram como foco a criação a partir das relações instauradas entre os atores, procuramos elaborar procedimentos que focassem a comunicação entre eles, seja pela fala ou pela linguagem corporal. Oida (2012, p. 44) a esse respeito escreveu que "a verdadeira comunicação não se dá apenas pelo contato físico ou através das palavras. Ela vem de um nível mais profundo e poderíamos descrevê-la como o encontro entre duas almas". Foi este encontro mais profundo entre dois atores que objetivamos alcançar por meio das estratégias relacionais extraídas dos princípios da "capoeira" e do "aikido". Como suporte a este tema recorremos também a Martin Buber, filósofo e teólogo alemão, que dedicou vários de seus trabalhos às discussões sobre as relações entre as pessoas, e concebeu as palavras princípio Eu-Tu, Eu-Isso e Tu Eterno para explicar esses fenômenos. Considerando, portanto, que estamos utilizando como base para a pesquisa o "aikido" e a "capoeira" que são artes marciais que têm como importantes fundamentos a relação e as afetações de um para o outro, e que buscamos a intensificação das afetações entre os atores em seu processo criativo, entendemos que este filósofo seja de grande contribuição para o aprofundamento desta pesquisa.

Para Buber, 1996, o ser humano, a partir do momento que nasce cria vínculos e interage com o que o cerca necessariamente. Para este teólogo o Eu-tu se refere ao mundo da relação e para ser proferida necessita da reciprocidade e da totalidade do ser. Ela é direta, sem mediações. Seria na dimensão do Eu-Tu que os seres humanos teriam suas capacidades de se afetarem aumentadas, atingindo, de acordo com nosso entendimento, o que Spinoza defendia sobre os encontros alegres e úteis.

Para Buber o mundo das relações existe em três esferas, explicadas por ele a seguir:

Primeira: a vida com a natureza: aqui a vida vibra no escuro e permanece abaixo da linguagem (...) Segunda: vida com homens: aqui 
a relação se manifesta e entra a linguagem. Nós podemos dar e receber o $T u$. Terceira: a vida com os seres espirituais. Aqui a relação está envolvida em uma nuvem e se revela por si só.$^{33}$ (BUBER, 1996, p. 56-57)

Percebe-se, assim, que quando Buber, 1996, trata da relação, ele não aborda apenas o aspecto pessoa-pessoa, mas inclui as coisas à volta e o mundo invisível. Neste ponto ele entra em consonância com Merleau-Ponty, 1999, Noe, 2009, e Spinoza, 2009, que também apontam como característica fundamental do ser humano a conexão com o que e quem o cerca e as consequências que estas conexões podem trazer. Estabelecendo um paralelo entre este pensamento e as artes marciais aqui estudadas, percebemos que em ambas existe a concepção de que o mundo que nos cerca não é apenas aquele que podemos ver e tocar, mas é também aquele que pode ser percebido no fluído vital que me conecta com o universo, $k i$, na energia que pulsa em uma roda de "capoeira", na evocação da ancestralidade e em tantas outras formas de manifestação invisíveis aos olhos, mas que podem ser percebidas pelo corpo e que acabam por ampliar o conceito de relação do ser no mundo. Acrescente-se ainda, segundo nosso entendimento, que quando Buber, 1996, trata da reciprocidade e da imediatidade nas relações seja com as pessoas, seja com a natureza ou com seres espirituais, ele traz para a discussão a potencialização dessas afetações por meio da presença e da contribuição "útil” de um para o outro.

Em contraposição ao Eu-Tu que é a representação da relação recíproca e sem mediações, Buber, 1996, apresenta a palavra princípio Eu-Isso que é relativo ao mundo da experiência, da utilização, do conhecimento e da observação. Para ele, quando o homem identifica no outro um simples objeto para ser experimentado e utilizado, ele perde a relação. Buber explica então que:

Eu da palavra-princípio Eu- Tu é diferente do Eu da palavra-princípio Eu-Isso. O Eu da palavra-princípio Eu-Isso aparece como egótico e toma consciência de si como sujeito (de experiência e de utilização) $\mathrm{O}$ Eu da palavra-princípio Eu-Tu aparece como pessoa e se conscientiza como subjetividade. (BUBER, 1974, p. 73)

33. "Three are the spheres in which the world of relation arises. The first: life with nature. Here the relation vibrates in the dark and remains below language. ...The second: life with men. Here the relation is manifest and enters language. We can give and receive the You. The third: life with spiritual beings. Here the relation is wrapped in a cloud but reveals itself." (p. 56-57) 
Temos, portanto, que o Eu da relação é diferente do Eu sem o Tu. É no contato com o Tu que o Eu se revela. Nesta relação os dois seres se conectam mutuamente, sem preparações ou antecipações. O que acontece entre eles é presente. Neste instante de presença eles vivem de maneira direta e, de fato, um diálogo acontece entre eles, mas não necessariamente com palavras. Ao nos entregarmos a esta conexão, respondemos com nosso corpo, nossa ação e não existe mais o Eu separado do Tu, os dois formam uma totalidade e se relacionam a partir do que ocorre nesse momento, sem prévia organização.

Explicando esse pensamento, Buber expõe:

O propósito da relação é a relação em si - no contato com o Tu. Assim que entramos em contato com o Tu, nós somos tocados por um sopro da vida eterna.

Quem se coloca em relação participa de uma atualidade, quer dizer, em um ser que não é meramente parte dele e nem está meramente fora dele. Toda atualidade é uma atividade da qual participo sem me apropriar dele. Onde não há participação, não há atualidade. ... Quanto mais diretamente o Tu é tocado, mais perfeita é a participação. ${ }^{34}$ (BUBER, 1996, p. 112-113)

O Eu na conexão com o Isso sai da relação de entrega e passa a ser um observador. Aquele ou aquilo que está em contato com o Eu neste caso é apenas um objeto de estudo e de análise. $\mathrm{O} \mathrm{Eu}$, com este intuito, não participa, não interage com o objeto, mas age sobre ele, o manipula, o experimenta. Não existe, por consequência, a reciprocidade porque não existe o "entre", apenas o Eu tomando iniciativa sobre o mundo. Seria por assim dizer, uma via de mão única onde o Eu age e o Tu recebe esta ação. Por isto, Buber define o Eu do Eu-Isso como "egótico":

A pessoa se torna consciente de si como participante do ser, como um ser-com (...) O egótico se torna consciente de si como um ser que é desse jeito e não daquele. A pessoa diz: "Eu sou"; o egótico diz: "É assim que eu sou". "Conhece-te a ti mesmo" significa para a pessoa: conhece-te como ser. Para o egótico quer dizer: conhece o teu jeito de ser. Se afastando dos outros, o egótico se distancia do Ser.(...) A pessoa contempla o seu si-mesmo; o egótico ocupa-se com o seu "meu" : meus jeito, minha raça, meu agir, meu gênio. O egótico não

34. "The purpose of relation is the relation itself - touching the You. For as soon as we touch a You, we are touched by a breath of eternal life. Whoever stands in relation, participates in an actuality; that is, in a being that is neither merely a part of him nor merely outside him. All actuality is an actuality in which I participate without being able to appropriate it. Where there is no participation, there is no actuality.... The more directly the You is touched, the more perfect is the participation." (BUBER, 1996, p. 112-113) 
participa de nenhuma atualidade e nem a conquista. Ele se coloca afastado de todo o resto e tenta se apossar o máximo que pode pela experiência e pela utilização ${ }^{35}$. (BUBER, 1996, p. 113-114)

Buber, 1996, reforça aqui que o Eu quando se coloca na relação com o Isso se fecha para o que o entorno tem para oferecer, e tenta exaustivamente se impor sobre ele. O outro nessa relação deixa de ser parte do processo de formação subjetiva do Eu e passa a servir exclusivamente para sua autoafirmação, caminhando ambos para um empobrecimento e esvaziamento da relação. A reciprocidade e a receptividade neste caso não encontram lugar.

Buber, 1996, esclarece, entretanto, que ninguém está o tempo todo na relação Eu-Tu e nem na relação Eu-Isso. O homem no decorrer de sua vida transita de um estado para outro constantemente. Entretanto "alguns homens são tão focados na pessoalidade que se podem chamar de pessoas, e outros têm seu foco tão direcionado para o ego que são chamados de egóicos. E é nessa transição de um para outro que a verdadeira história acontece"36 (BUBER, 1996, p. 114-115).

Podemos estabelecer nesta transição entre Eu-Isso e Eu-Tu trazida por Buber uma conexão com a fluidez mencionada pelo Mihaly Csikszentmihalyi, 1975. Quando a atividade e os elementos que a compõem se fundem com o sujeito que a pratica e passam ambos a fazer parte de um mesmo fluxo, não existe mais um separado do outro. Vemos neste caso o Eu-Tu presentificado. Entretanto, se o praticante ainda não tem um grau de experiência necessária para que esta fluidez aconteça, ele está mais próximo do Eu-Isso, uma vez que não existe de fato uma relação recíproca acontecendo. E como bem lembra Csikszentmihalyi, 1975, esta fluidez não se dá o tempo todo, e oscila durante o desenvolvimento da atividade. O que se busca com a prática é justamente alcançar o estado de fluidez o maior tempo possível. Esta oscilação entre os tipos de relação acontece também quando identificamos um ânimo de competição mais acirrado

35. "The person becomes conscious of himself as participating in being, as being-with...The ego becomes conscious of himself as being this way and not that. The person says', 'I am'; the ego says, 'That's how I Am'. 'Know Thyself' means to the person: Know yourself as being. To the ego it means: know your being-that way. By setting himself apart from others, the ego moves away from being. ... The person beholds his self; the ego occupies himself with this My: my manner, my race, my Works, my genius. The ego does not participate in any actuality nor does he gain any. He sets himself apart from everything else and tries to possess as much as possible by means of experience and use.” (BUBER, 1996, p. 113-114)

36. “(...) some men are so person-oriented that one may call them persons, while others are so egooriented that one may call them egos. Between these and those true history takes place." 
entre os jogadores, em que um tenta sobrepor-se sobre o outro ao invés de buscarem juntos desafios comuns. Vemos esta transição de estados acontecendo também tanto nos treinos de "capoeira" como nos de "aikido", a exemplo do que ocorre em nosso dia a dia. Em ambas as artes identificamos, ora o Eu-Tu ora o Eu-Isso se revelando, desde o contato com o parceiro até o contato com elementos sonoros, corporais e físicos como as armas próprias do "aikido", jo e boken, e instrumentos utilizados na "capoeira", berimbau, agogô, pandeiro, atabaque e reco-reco.

A fim de ilustrar esse processo convém relembrar o que Noe expõe sobre a qualidade da atenção e o grau de energia gastos pelos iniciantes e pelos experts, tomando como referência o uso do jo. Quando um Nidan - graduado faixa preta 2. ${ }^{\circ}$ DAN - manipula um jo, sua relação com esta arma é de grande intimidade e segurança, como se ambos fizessem parte de um só corpo. Neste caso, entendemos que a relação Eu-Tu está acontecendo, uma vez que o contato do jo com o aikidoista e vice-versa se dá de maneira harmônica e plena, como se o bastão fosse uma extensão do corpo. Mas, para um aikidoista iniciante, a manipulação de um jo é atrapalhada, difícil e desgastante e esta arma, nesta hipótese, passa a ser apenas um objeto com o qual o praticante tem que conviver por um tempo e aprender a movimentá-lo. Neste caso, identificamos a presença do Eu-Isso, ficando ausente o estado de relação efetiva. Tomando como referência a "capoeira", outro exemplo que pensamos ser um rompimento do Eu-Tu, é quando em uma roda vemos dois capoeiristas "se trombando" no jogo por falta de escuta em razão, via de regra, da inexperiência de um deles ou de ambos.

Nessa situação, entendemos que um não se relaciona com o outro, por estar a atenção mais centrada em si e na dificuldade de realizar determinado movimento. Percebemos, portanto, que podemos presenciar nas duas artes marciais em questão tanto a relação plena, que é o que se busca com a constância da prática, como o estado de utilização, como os descritos anteriormente. Buber defende, portanto, que, quanto mais uma pessoa se centra no diálogo, na busca do genuíno encontro com o outro, entregando-se para este momento, sem a preocupação de prever ou impor nada, mais "pessoa” ele será considerado. Nesta relação não existe um que dá e um que recebe, pois a receptividade e a atividade estão acontecendo simultaneamente na relação. Entretanto, quanto mais a pessoa se centrar em si mesmo, se separando do outro ou tendo no outro apenas um objeto de experimentação e de apropriação, mais ele empobrecerá sua dimensão humana dialógica. 
Este filósofo vai ainda além estendendo a dimensão relacional do Eu para o Tueterno afirmando que todas as relações se entrelaçam nele, como se o Tu só pudesse se saciar ao encontrar o Tu infinito. Através de cada Tu individual o Tu-Eterno é invocado. Quem entra na relação com o Tu-Eterno entra na relação absoluta onde não há mais nada isolado. Nesta relação todos os seres, coisas, elementos da natureza estão incluídos. Dispõe ainda que "entrar na relação pura não envolve ignorar tudo, mas ver tudo no Tu; não renunciando ao mundo, mas proporcionar-lhe fundamentação" 37 (BUBUER, 1996, p. 127).

Tomando como referência o "aikido" e a "capoeira", com todas as suas complexidades culturais, identificamos nos pensamentos dos filósofos apontados importantes conexões com estas artes, uma vez que o que as movimenta primordialmente são o autoconhecimento, as relações com os parceiros e com o que está no entorno e a potencialização destes encontros. Entendemos, portanto, tendo em vista estes aspectos, que estas artes marciais podem contribuir sobremaneira para o aprimoramento do trabalho do ator, pois podem colocá-lo em uma sintonia mais fina e mais harmônica com quem está trabalhando e com os objetos que estão ao seu alcance, maximizando qualitativamente seu trabalho. O resultado que se busca com esse processo é uma comunicação mais eficiente e uma estimulação mais potente de um ator pelo outro. Neste estado de comunicação efetiva, a improvisação e o jogo ganham muito mais potência, uma vez que os atores propõem e recebem na mesma proporção, dando início a um ciclo virtuoso. Envolver-se com o parceiro genuinamente e viver o instante preciso do contato, potencializando este encontro, sem se preocupar com o que se passou e com o que está por vir é a grande riqueza do trabalho do ator, bem como da convivência harmônica entre as pessoas. Assim, ao pensar nos procedimentos práticos para o trabalho com os atores, tomamos estas ideias como ponto de partida, de modo que as fundamentações teóricas e práticas se conectassem o tempo todo.

A fim de ilustrar as ideias expostas acima, especialmente as apresentadas por Buber, 1996, podemos citar alguns exemplos práticos:

37. "For entering into the pure relationship does not involve ignoring everything but seeing everything in the You, not renouncing the world but placing it upon its proper ground." (BUBER, 1996, p. 127) 
Quando tomamos como base a expansão do ki para criar uma proposta prática com exercícios de respiração conectados com o koshi, procuramos nos apoiar na primeira esfera apresentada por Buber, 1996;

Já quando se estabelecia um jogo entre os atores seguindo a dinâmica de uma roda de "capoeira" ou quando propusemos improvisações em duplas estimuladas pelos princípios do "aikido" de afetação mútua e de impulsão de um pelo outro, nos focamos na segunda esfera;

E quando evocamos a ancestralidade, tentando acessar uma dimensão invisível pelo ritual ou nos apoiamos na ideia de que somos todos iguais subordinados a uma energia que nos anima, nos embasamos na terceira esfera.

Mas como lembra Buber, 1996 o homem está sempre transitando entre o Eu-Tu e Eu-Isso e, da mesma forma, o ator em seu trabalho também passa de um estado para outro continuamente. Seguindo esta dinâmica, a natureza tanto pode ser parte do Eu como o Eu pode experimentá-la. O outro que se conecta com o Eu pode ser seu objeto de estudo ou pode ser por meio de quem o Eu se revela e se desenvolve. E o reconhecimento destes dois estados foi levado em conta nesta pesquisa para conduzir os procedimentos práticos com os atores. Temos, portanto, que, tendo em vista estas duas perspectivas, para esta investigação, o importante foi conseguir aproveitar o melhor de cada momento, seja ele o da relação ou o da experimentação para a potencialização do trabalho do ator. Entretanto, na maior parte deste processo nos concentramos na busca pela relação pessoa-pessoa - inserida na segunda esfera - por meio de procedimentos que contribuíssem para que a palavra princípio $E u-T u$ se estabelecesse pelo maior tempo possível durante os ensaios e nas apresentações públicas do resultado prático desta pesquisa.

Tendo como referência tudo o que foi aqui exposto, recorremos nesta etapa às improvisações em duplas e em grupo, variando os tipos de exigência e de estímulos, com o objetivo de atingir afetações diferentes e, por consequência, chegar a diversas qualidades de encontros. Conforme os atores iam desenvolvendo suas experimentações práticas, eu ia definindo qual caminho era melhor a ser tomado no restante do percurso. Assim como ocorreu com o trabalho de preparação individual, neste momento, os princípios extraídos do "aikido" e da "capoeira" deram suporte para a criação de conduções para as improvisações. Seguem algumas descritas abaixo. No DVD anexo pode-se assistir um trecho dessas improvisações. 
A partir do "aikido":

1) movimentem-se em dupla como se os quadris estivessem ligados por um fio invisível;

2) conectem-se fisicamente com o parceiro deixando-se conduzir por ele de olhos fechados;

3) conduzam-se um ao outro por um toque sutil, um impulsionando o outro. Aproveitem o impulso recebido para produzir um movimento;

4) impulsionem o parceiro tocando-o em alguma parte específica do corpo e recebam como reação outro impulso -impulso e contra-impulso;

5) deixem o movimento do parceiro reverberar no corpo de vocês a distância;

6) busquem apoios no corpo do outro. O outro deve se ajustar a esse contato de modo a manter a estabilidade e responder buscando também um apoio no corpo do parceiro;

7) improvisem a partir dos agarramentos -formas de imobilizar o parceiro. Variem a velocidade e o tônus do agarramento, a fim de fornecer estímulos diferentes a cada contato;

8) conectem-se apenas com o olhar como se estivessem se empurrando ou se puxando;

9) com os punhos presos firmemente pelo parceiro, "dancem" transferindo impulsos corporais para o parceiro, que deve se manter disponível e receptível a estes impulsos;

A partir da "capoeira":

1) preencham os espaços vazios deixados pelos movimentos do parceiro;

2) movimentem-se como se quisessem avançar sobre o corpo do parceiro, obrigando-o a se deslocar de modo que o outro complete seu movimento;

3) movimentem-se sem contato físico nenhum, mas mantendo a relação especialmente pelo olhar;

4) procure deslocar o outro, cercá-lo, encurralá-lo com o movimento. O outro deve reagir procurando fazer o mesmo;

5) joguem/improvisem em duplas como se um estivessem perguntando com o corpo e o outro respondendo,

6) joguem/improvisem em duplas como se os corpos fossem parte de uma onda que se movimentam continuamente e se completam; 
7) imaginem-se dentro de um círculo pequeno e toda a movimentação tem que acontecer dentro desse espaço, criando trajetórias circulares pelo espaço por meio da interação entre os corpos;

8) caminhem pelo espaço, se afastando e se aproximando sem falar. $\mathrm{Na}$ sequência procurem chegar a níveis espaciais iguais (baixo, médio e alto) sem comunicação verbal. Procurem se deslocar pelo espaço buscando soluções semelhantes, ou seja, os dois em baixo, os dois distantes e assim por diante;

9) improvisem apenas no nível baixo como se tivesse um teto sobre vocês impedindo de se levantarem, mas sem perder a conexão com o parceiro;

10) improvisem a partir de elementos da capoeira que proponham o toque: chamada, vingativa, toque de mão, etc.

As improvisações desta fase tinham inicialmente como apoio apenas música e conduções como as descritas acima. A questão da instauração da relação foi complicada a princípio, mas com a persistência das improvisações e dos jogos ela foi sendo mais bem resolvida. Uma das dificuldades identificadas para o estabelecimento da relação foi a racionalidade intervindo no que o ator estava realizando e a dificuldade com o próprio corpo no que diz respeito à flexibilidade e a coordenação, que prejudicavam a fluidez, impondo limitações às improvisações. $\mathrm{O}$ foco do ator nestes casos deixava de ser o parceiro e surgiam pensamentos como "o que vou fazer na sequência?", "como faço isso?", “O que estou fazendo não está bom”, “o que mais de interessante posso fazer?”, dentre outros. Aos poucos, com a insistência em manter o foco no parceiro, em estar presente naquele momento, em usar a respiração para relaxar e perceber com sinceridade os estímulos que o outro estava dando, esse problema foi sendo diminuído. Após um tempo de trabalho, os atores foram se sentindo mais a vontade e imagens corporais bastante interessantes foram surgindo.

Estando os atores então, mais tranquilos, acrescentei textos que deveriam ser aproveitados por eles nas improvisações. Assim, o que estava sendo experimentado pelos atores deveria ser estimulado pelas circunstâncias propostas pelos textos escolhidos. Neste momento percebi um retrocesso em relação ao que eles estavam desenvolvendo uma vez que não estavam conseguindo fazer uso das circunstâncias propostas pelo texto para fomentar a relação entre eles. Era possível observar oscilações entre momentos de presença e momentos de preocupação. Com o decorrer dos ensaios 
eles foram ficando mais confortáveis e mais seguros e então propostas cênicas interessantes foram aparecendo.

Com o ator Wagner Cerqueira utilizei o texto A Serpente de Nelson Rodrigues, cujas imagens seguem abaixo. Escolhemos uma cena e a experimentamos em duas versões: uma a partir do "aikido" e outra a partir da "capoeira". Embora breve, pudemos verificar neste processo o surgimento de duas propostas cênicas totalmente diversas. Estes esboços de cena foram apresentados em uma Mostra do Cepeca que se realizou em agosto de 2013 no Teatro Escola Macunaíma. No DVD anexo pode-se assistir estas cenas.

Imagens de 64 a 67: A Serpente, com "capoeira"
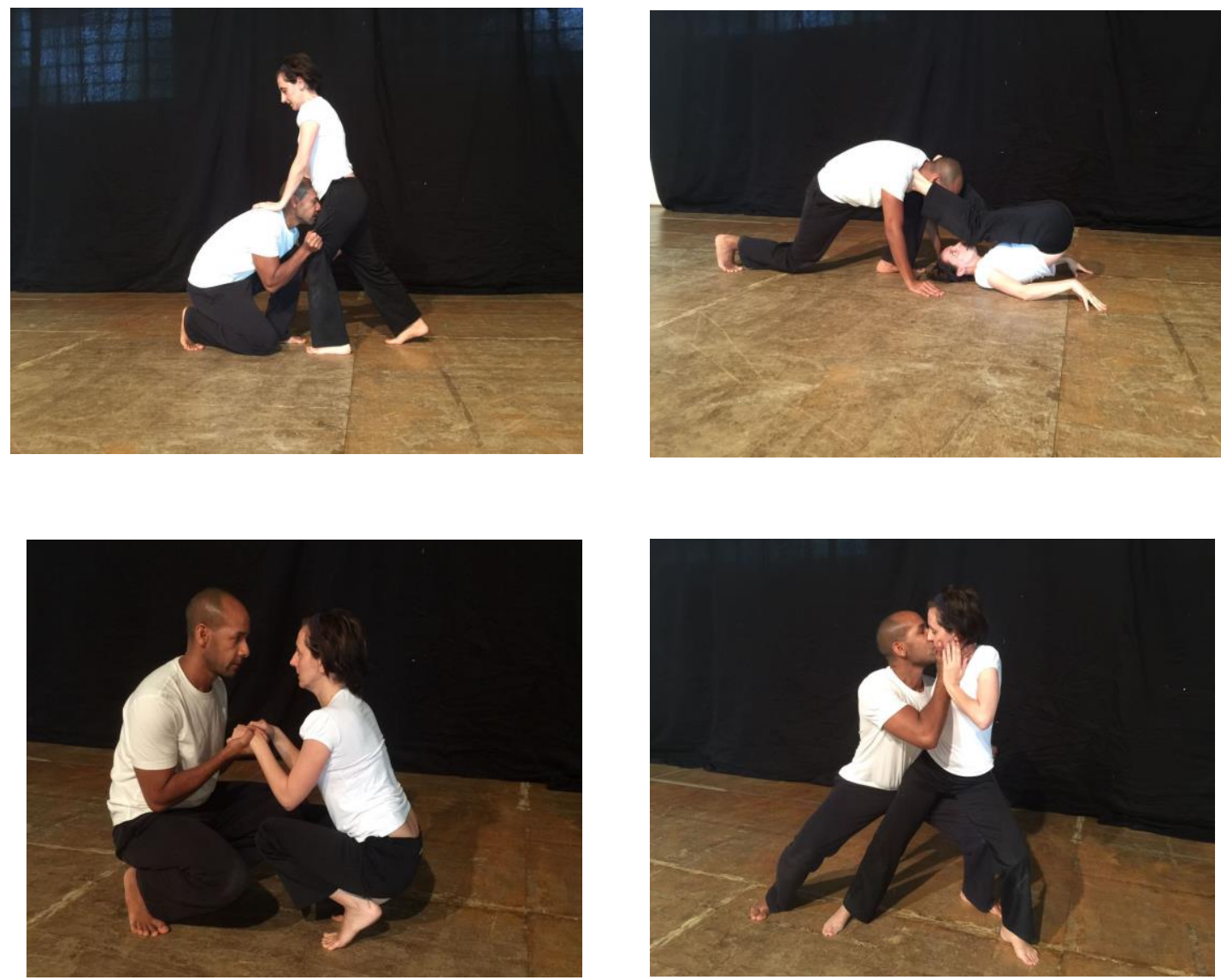

Fontes: arquivo do autor. 
Imagens de 68 a 71: A Serpente, com o "aikido":
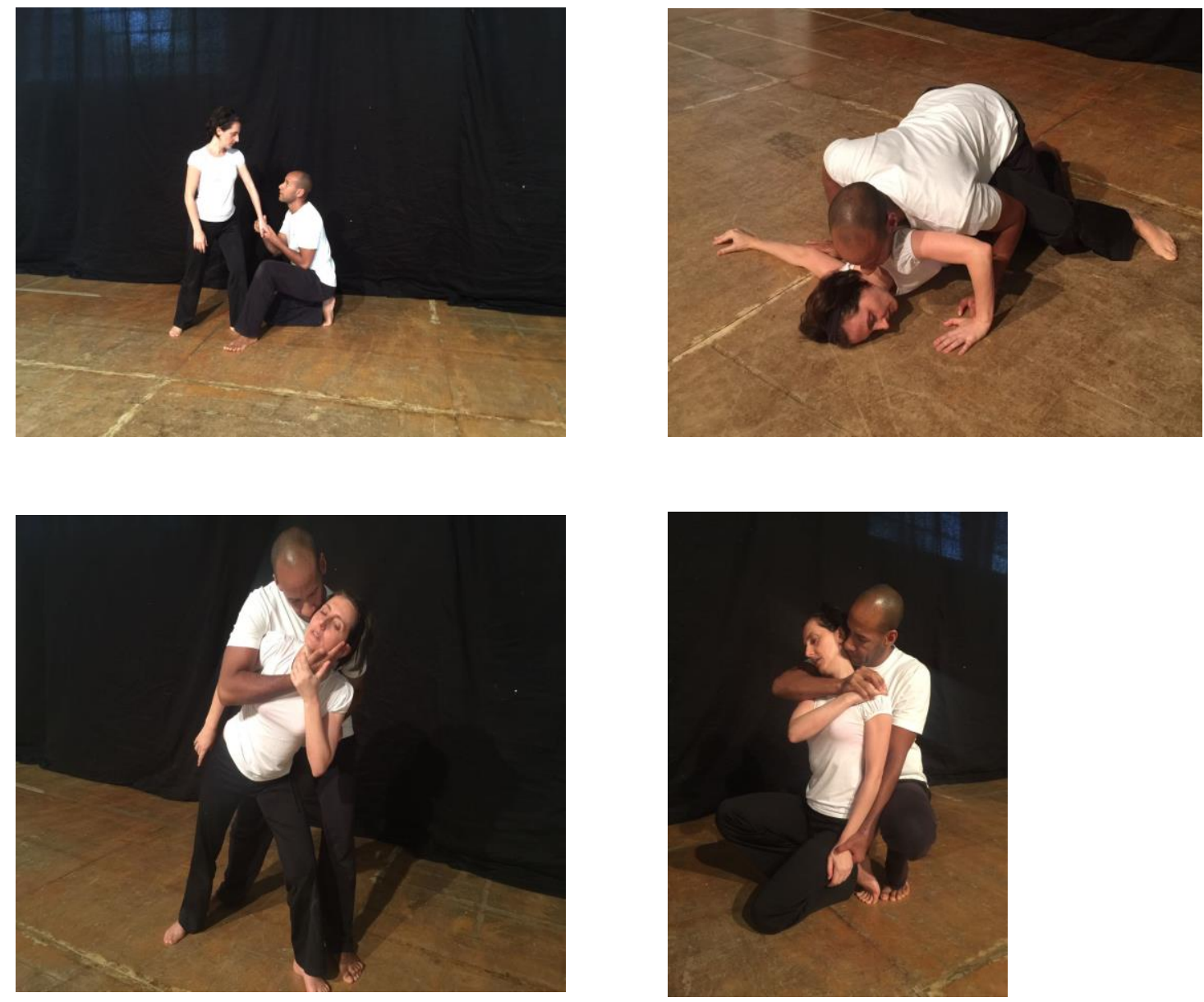

Fontes: arquivo do autor.

Já com as atrizes Nathalia Amadei, Carolina Loureiro e Larissa Hupallo, com quem também trabalhei no primeiro ano do doutoramento, concebemos algumas cenas a partir de trechos de O Inferno de Dante Alighieri cujas imagens seguem abaixo.

Imagens 72 e 73: Inferno, com “aikido"
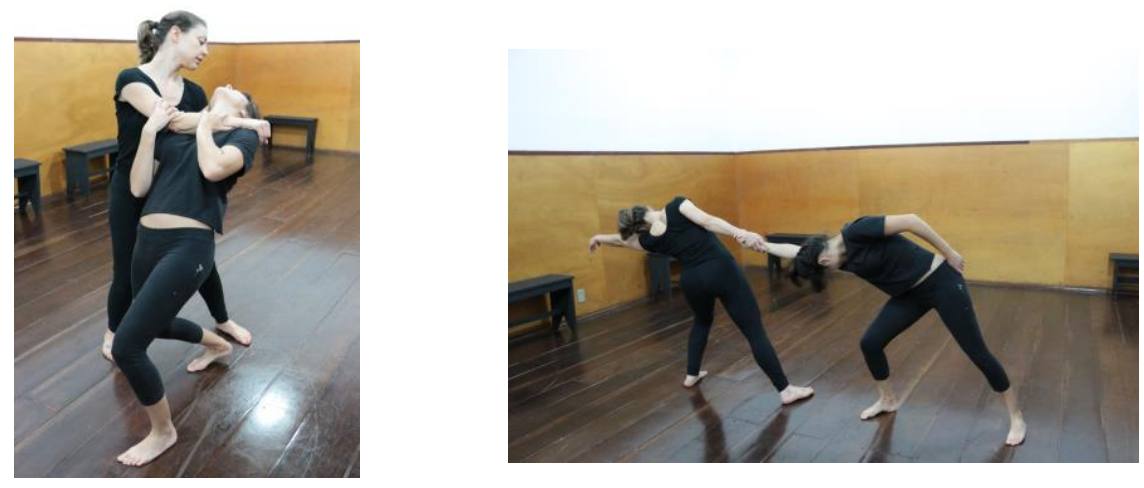

Fontes: arquivo do autor. 
Imagens 74 e 75: Inferno, com "capoeira":
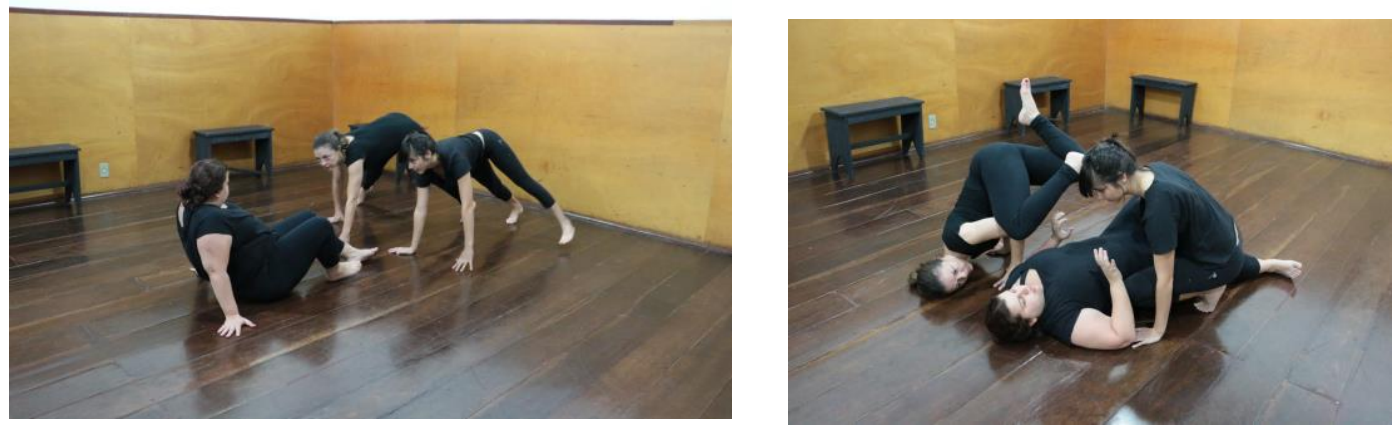

Fontes: arquivo do autor.

Continuamos a pesquisar e concebemos outro exercício cênico que teve como base o conto A Negrinha, de Monteiro Lobato. Nesta demonstração focamos na relação entre uma senhora rígida, religiosa e conservadora, "negrinha" que lhe servia como serviçal e aguentava submissamente seus abusos e uma criada cujas atitudes intensificavam o sofrimento de "negrinha". Para completar a narrativa, duas crianças familiares da senhora- aparecem na casa com uma boneca e dão novo frescor a vida de negrinha, mas isso só a faz se dar conta de sua infelicidade o que a conduz à morte. Os elementos do "aikido" e da "capoeira" serviram conjuntamente de estímulo para as atrizes comporem suas ações e movimentações, ou seja, a criação de cada personagem recebeu contribuição das duas artes marciais indistintamente. Seguem abaixo algumas fotos que ilustram o processo. No DVD anexo pode-se assistir esta cena.

Imagens de 76 e 77: processo criativo.
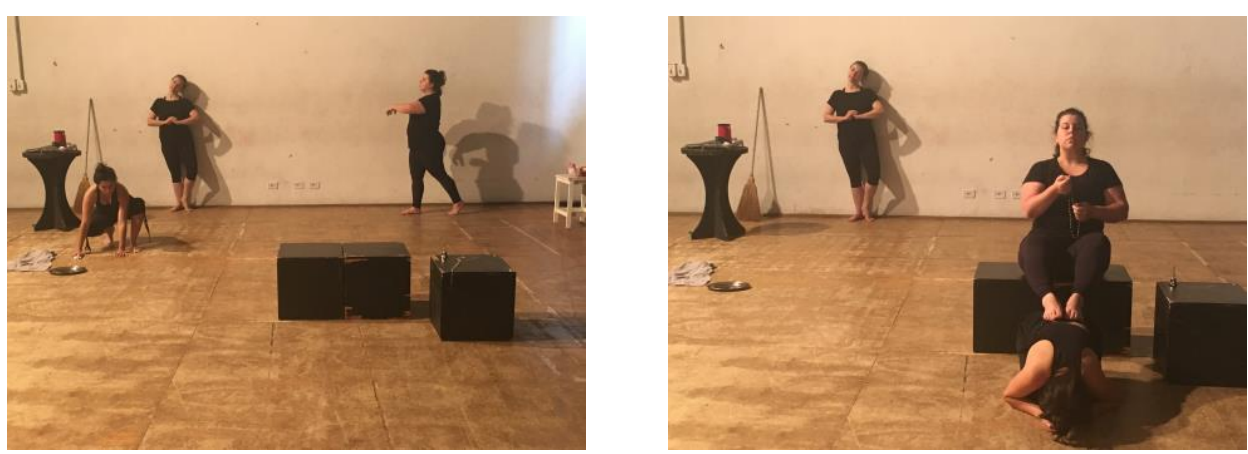

Fontes: arquivo do autor. 
Imagens de 78 a 81: processo criativo.
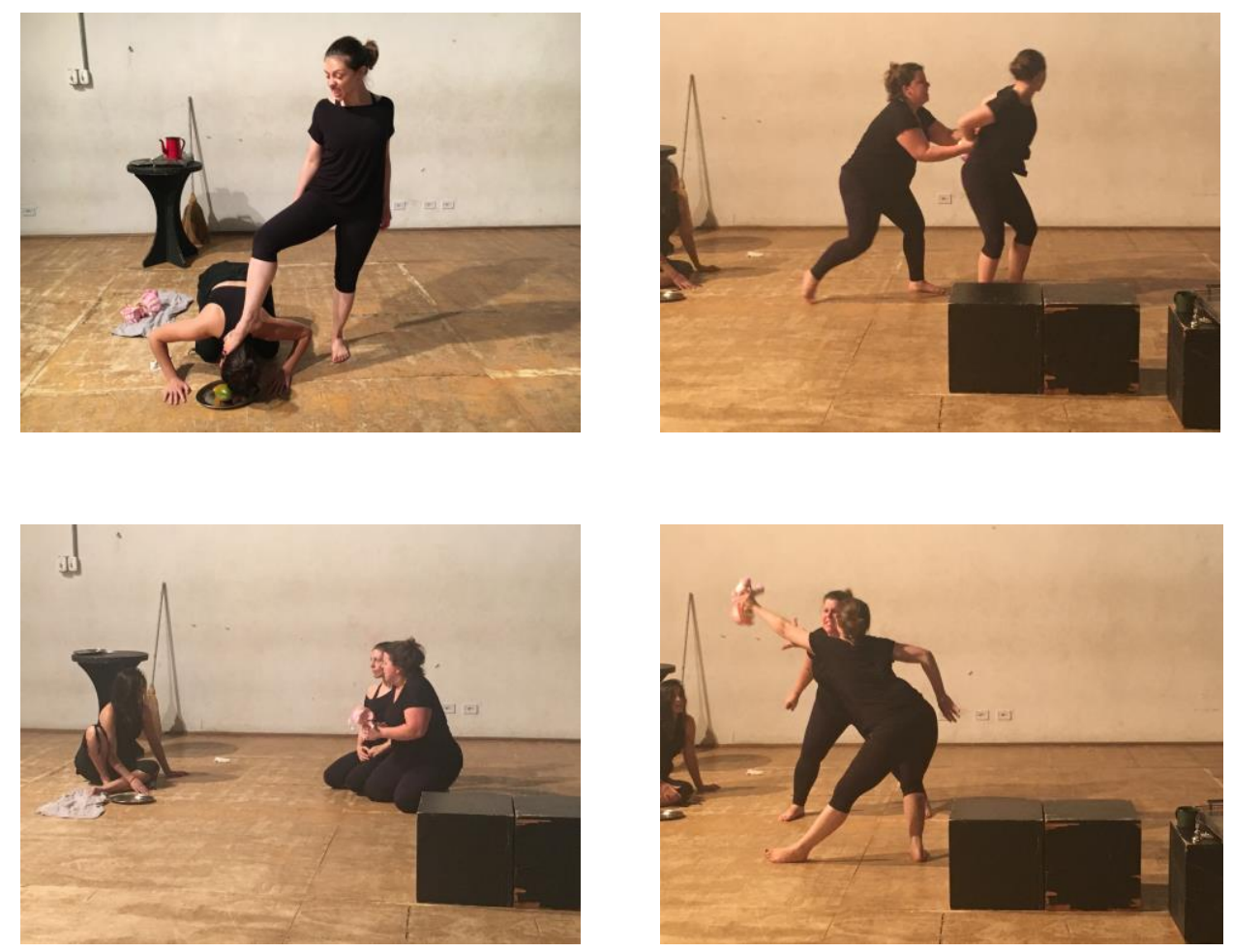

Fontes: arquivo do autor.

Com o fim desses dois núcleos, segui com as experimentações com o terceiro que se formou e utilizamos temas e textos extraídos da peça Hamlet.

Tendo definido o grupo e o texto que iríamos utilizar como estímulo, começamos as improvisações primeiramente pela "capoeira" e adotamos aqui procedimentos semelhantes ao que vínhamos desenvolvendo no início do processo com os núcleos apresentados anteriormente, que foi o de iniciar os ensaios com um aquecimento que favorecesse o que pretendíamos desenvolver na sequência e partir para experimentações corporais e improvisações livres, ou seja, sem um texto ou tema específico guiando a criação e mantendo como referência os princípios selecionados na fase de estudos das técnicas. Todos os atores neste momento improvisavam com todos, revezando as duplas. Retomamos então, o procedimento de registros escritos das sensações, impressões, imagens e ideias surgidas durante as experimentações. Neste momento, pedi que anotassem apenas palavras em vez de frases, a fim de evitar racionalizações sobre o que tinham vivido. Munidos dessas anotações conversamos sobre o texto e procuramos estabelecer as conexões entre o que foi escrito pelos atores e as circunstâncias da peça. Identificamos, assim, uma ponte entre algumas palavras anotadas e a cena de Hamlet com o fantasma do pai assassinado, e utilizamos esta 
conexão como estímulo para as improvisações. As palavras foram: cuidado, sorrateiro, curiosidade, escuro, medo, enfrentamento, insegurança/segurança e atenção.

Mantendo o foco na criação desta cena, nos ativemos às circunstâncias, mas colocamos como regra que inicialmente não haveria fala, ou seja, a comunicação se daria apenas por diálogo corporal. Nesta etapa os elementos do jogo da "capoeira" foram muito importantes. A fim de canalizar a energia e aumentar a potencialidade da criação, já que estávamos utilizando como referência a "capoeira", recorremos à "compra de jogo" que acontece na roda de "capoeira" para elaborar o procedimento de "Roda de Improviso". Deveríamos, então, nos posicionar em roda enquanto uma dupla iniciaria a improvisação, se colocando como Hamlet e fantasma. Quem estivesse em volta tinha a responsabilidade de não deixar a energia baixar, devendo ficar atento ao que estivesse acontecendo no centro, percebendo o que aparecesse de interessante daquela relação e comprando o jogo/improvisação quando a relação começasse a se perder. A troca deveria ser, portanto, dinâmica e constante. Todos eram responsáveis pelo andamento da roda. Além disso, ao comprar a improvisação com um dos atores, poder-se-ia assumir o personagem que quisesse. O que se observava desses improvisos é que, ao trocar os atores, elementos diferentes eram trazidos para a cena, apesar de estarmos lindando com as mesmas circunstâncias. A "volta ao mundo" foi utilizada neste momento como estratégia de instauração de relação ou simplesmente para descansar sem interromper o jogo. O procedimento da "roda de improvisação" também definiu outro aspecto importante da encenação que foi a troca constante de atores para cada personagem, ou seja, não seria definido um ator para cada personagem. Partir-seia, portanto, da ideia de que, a cada cena, os atores assumiriam funções diferentes como se estivessem comprando o jogo e assumindo aquela posição.

O procedimento da "Roda de Improviso" foi adotado por mim pela primeira vez com um grupo de alunos do Teatro Escola Macunaíma em 2013, onde dava aula de Expressão Corporal. Esta ideia foi sendo desenvolvida e a experimentei novamente em uma oficina que dei na Universidade da Costa Rica, em San Jose, em 2014. Nestes dois casos identifiquei um início difícil, onde os alunos se colocavam simplesmente como se estivessem jogando "capoeira". Neste momento os alunos não estavam usando os princípios como inspiração, mas estavam praticamente executando uma reprodução delas com algumas variações. Entretanto, gradualmente, conforme eu fui chamando a atenção para alguns princípios, a improvisação foi se transformando e, gradualmente, 
outras nuances foram surgindo. Foi importante observar que na prática os alunos iam encontrando suas próprias formas de criação a partir do repertório que possuíam.

De volta a São Paulo, retomei este procedimento para a criação da cena entre Hamlet e Fantasma e aos poucos, a partir do material levantado, fomos esboçando a cena. Como gostamos da ideia da roda nesta cena, resolvemos mantê-la para a encenação. Por esta razão, todos os atores começaram a aprender a tocar berimbau com um dos atores do grupo, Jefferson Mathias. Com este estímulo, começamos a pensar em toques que auxiliariam a criação de atmosfera. A partir desta experiência decidimos que toda a peça seria permeada com sons e músicas produzidas em cena pelos atores e excluímos músicas reproduzidas mecanicamente.

Todo o material selecionado para a concepção da dramaturgia teve como critérios a apropriação do movimento pelo ator e sua organicidade, a conexão com as circunstâncias da cena, a relação com os elementos da arte marcial utilizada e a plasticidade do movimento criado.

Segue abaixo algumas imagens que ilustram o processo. No DVD anexo pode-se assistir esta cena.

Imagens 82 e 83: processo criativo.
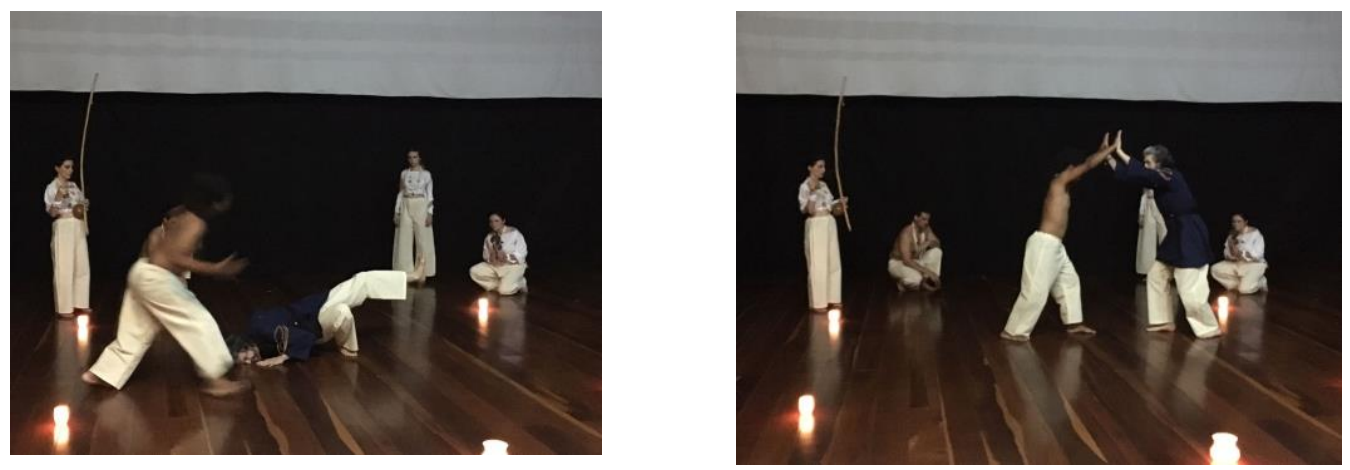

Fontes: arquivo do autor.

Outro exemplo de construção de dramaturgia a partir das improvisações é a cena do teatro em que uma trupe de atores encena a morte do Rei a pedido de Hamlet, a fim de desmascarar o tio. Para esta cena usamos como fonte de inspiração a "capoeira". Recorremos, portanto, aos seguintes elementos encontrados no contexto da "capoeira": a musicalidade, a narrativa de uma história de um antepassado, o conceito da roda, o jogo e algumas qualidades de movimento presentes nos golpes e esquivas. Como os atores tocariam e cantariam, dedicamos um período longo do treinamento à prática do berimbau e do pandeiro. Iniciamos as primeiras improvisações a partir da ideia de uma 
trupe de artistas de rua que chega à cidade. Nestes improvisos lançamos mão de todos os princípios selecionados ao longo do processo de estudo e de improvisação aliados à ideia de roda com a inclusão da plateia, como se uma grande roda de "capoeira" estivesse sendo formada por todos os presentes. A plateia estaria na posição dos reis assistindo a encenação. Dessa forma, seria como se os espectadores estivessem efetivamente dentro da cena.

Durante os improvisos selecionamos as músicas Era Uma Noite Sem Lua e Chora Capoeira, do Mestre Toni Vargas, para compor a dramaturgia da cena. Percebemos, em relação à primeira música, uma interessante conexão entre o ataque que aparece à surdina durante uma noite escura presente na letra e o assassinato traiçoeiro do Rei Hamlet. Essa música foi intercalada com um poema composto por mim tendo como inspiração as narrativas que vemos em músicas de "capoeira" como as realizadas pelo próprio Toni Vargas.

\begin{tabular}{|c|c|}
\hline POEMA & ERA UMA NOITE SEM LUA \\
\hline $\begin{array}{l}\text { Eu e meus amigos com coração e alegria } \\
\text { Carregando berimbau, caxixi e poesia } \\
\text { Vamos contar uma historia de grande covardia } \\
\text { Onde os envolvidos, acreditem, se entrelaçam em } \\
\text { maestria } \\
\text { Criando uma obra prima com muita ousadia } \\
\text { O resultado é um modelo que retrata a perfídia } \\
\text { A Ratoeira é seu nome e exala a insídia } \\
\text { Agora acomodem-se, que sem muito esforço } \\
\text { Mas talvez com um pouco de alvoroço, } \\
\text { Vamos contar com a ajuda de um moço } \\
\text { E também de uma moça, que não seja muito } \\
\text { insossa } \\
\text { Esta história onde a morte fere o mais forte } \\
\text { Pelas mãos de um irmão e de um consorte } \\
\text {--------- } \\
\text { Vou contá a história de um rei muito garboso } \\
\text { Que Tinha uma mulhé bela e formosa, mas tbm } \\
\text { muito ambiciosa } \\
\text { Ele era terno e carinhoso, a cuidava e a venerava } \\
\text { E nem um vento mais rude seu rosto lhe roçava }\end{array}$ & $\begin{array}{l}\text { Era uma noite sem lua } \\
\text { Era uma noite sem lua } \\
\text { Era uma noite sem lua } \\
\text { Era uma noite sem lua e eu tava sozinho } \\
\text { Fazendo do meu caminhar o meu próprio } \\
\text { caminho } \\
\text { Sentindo o aroma das rosas e a dor dos } \\
\text { espinhos } \\
\text { De repente apesar do escuro eu pude saber } \\
\text { Que havia alguém me espreitando sem ter nem } \\
\text { porquê } \\
\text { Era hora de luta e de morte, é matar ou morrer } \\
\text { A navalha passou me cortando era quase um } \\
\text { carinho } \\
\text { O meu sangue misturou-se ao pó e as pedras } \\
\text { do caminho } \\
\text { Era hora de pedir axé para o meu orixá } \\
\text { E partir para o jogo da morte, é perder ou } \\
\text { ganhar } \\
\text { Eu dei o bote certeiro da cobra, alguém me } \\
\text { guiou } \\
\text { Meia lua bem dada é a morte } \\
\text { E a luta acabou }\end{array}$ \\
\hline
\end{tabular}


Já a segunda música, que homenageia o Mestre Bimba, o criador da "capoeira regional", nos remeteu ao choro de um filho pela morte de seu pai. Assim, adaptamos a letra desta música às circunstâncias da peça e a inserimos na dramaturgia para pontuar a morte do rei por envenenamento.

\begin{tabular}{|l|l|}
\hline \multicolumn{1}{|c|}{ CHORA CAPOEIRA (somente a } & \multicolumn{1}{c|}{ ADAPTAÇÃO } \\
parte que usamos na cena) & \\
\hline $\begin{array}{l}\text { Chora capoeira } \\
\text { Capoeira chora } \\
\text { Chora capoeira } \\
\text { Mestre bimba foi se embora }\end{array}$ & $\begin{array}{l}\text { Chora meu amor } \\
\text { Meu amor agora chora } \\
\text { Chora meu amor que } \\
\text { Meu pai foi se embora }\end{array}$ \\
\hline
\end{tabular}

Ao longo dos ensaios decidimos que esta cena deveria ser mantida de forma improvisada, sem definir uma partitura física, pois entendemos que assim nos manteríamos mais próximos da essência da "capoeira" e conseguiríamos um estado jogo maior entre os atores. A única parte que partiturizamos foi o momento do envenenamento do Rei, em que as atrizes Renata Mazzei e Isabella Leonel recorreram à sinuosidade da ginga e à movimentação de perna presente na "capoeira" para a criação da cena. Neste caso, utilizamos os princípios da "capoeira" para improvisar e, destas improvisações, escolhemos os movimentos que achamos mais adequados a este momento.

Ignacio Munoz sobre o processo de criação dessa cena comenta:

Nesta cena o uso da "capoeira" ajudou principalmente a trabalhar a energia. É uma cena que exige interação direta com a plateia, criando o ambiente alegre e festivo próprio de uma trupe de teatro. Para isto a utilização de música me ajudou a entrar no estado e na energia que achei adequados para a cena. Os movimentos desta cena são improvisados e isto resulta fácil usando a "capoeira", pois também o jogo na roda é feito sem marcação.

Abaixo seguem algumas imagens desse processo. No DVD anexo pode-se assistir esta cena. 
Imagens de 84 a 87: processo criativo.
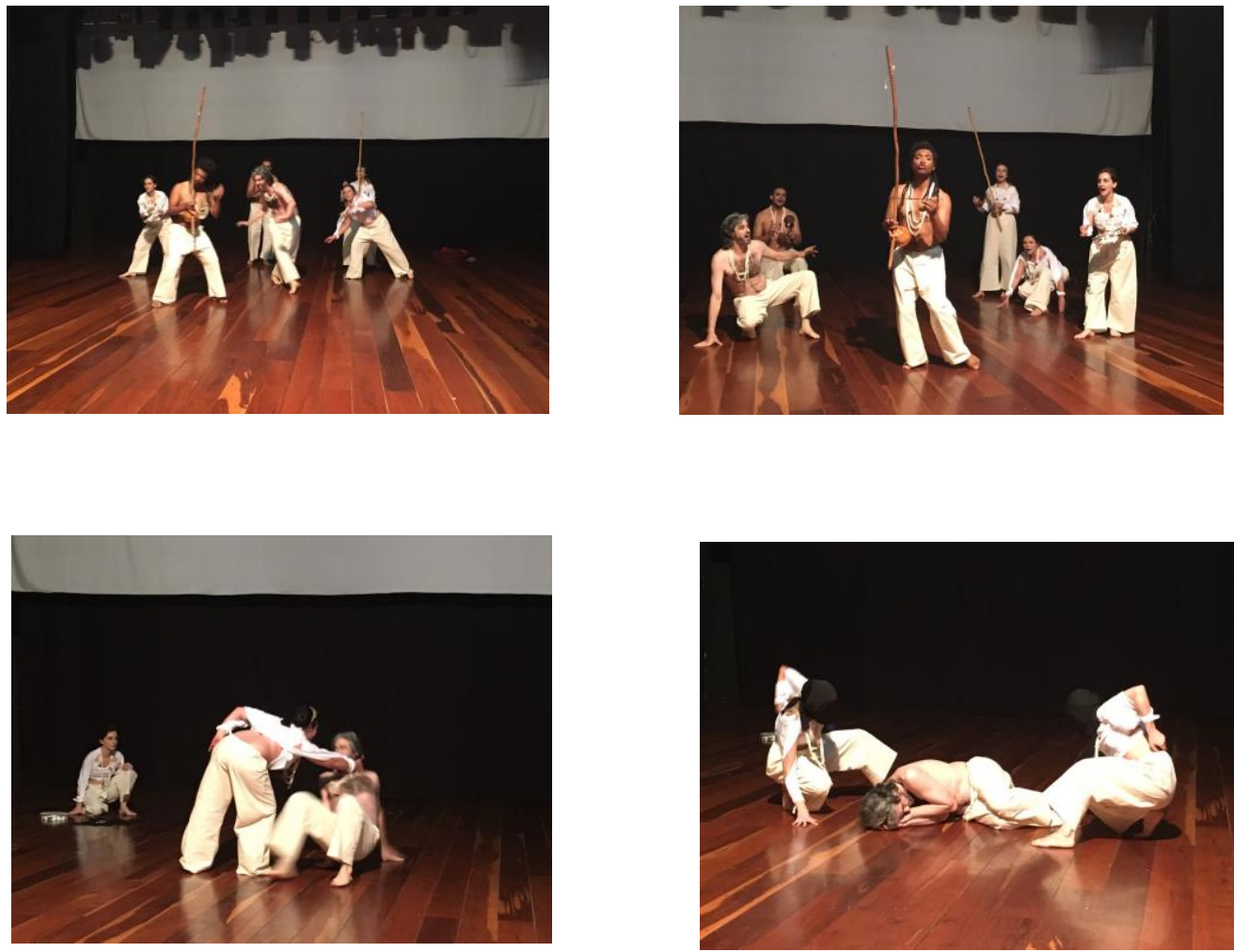

Fontes: arquivo do autor.

Ainda em relação à cena do teatro considero importante destacar mais um ponto em que é a relação se estabelece entre o Rei e a Rainha durante a encenação do assassinato contratada por Hamlet. Os dois atores da pesquisa, Helena Semedo e Ignacio Muñoz, encontraram grandes dificuldades no treinamento com os elementos da "capoeira", especialmente no que diz respeito ao molejo, a sinuosidade da ginga e a conexão com o parceiro. Para esta cena utilizamos justamente a ideia do jogo para criar a relação entre eles e elaboramos um treinamento focando no desenvolvimento dos elementos corporais que eram complicados para os atores. Com o passar do tempo foram se sentindo mais a vontade durante o improviso e começaram a se conectar melhor entre eles. Este treinamento refletiu na melhora da performance em outras cenas que também pedia o uso do molejo e do jogo.

Ignacio Muñoz registrou as seguintes impressões sobre a experiência:

$\mathrm{Na}$ dança dos atores que representam ao rei e a rainha, foi muito importante o trabalho realizado durante os ensaios com o treinamento focando na capoeira. A prática da ginga e a sinuosidade do capoeirista acabaram tendo um reflexo no meu corpo, que ganhou em fluidez e repertório. A sinuosidade foi aqui utilizada 
por nós com a ideia de sedução e sensualidade. Nesta cena para mim era importante entrar no jogo, criar a partir da relação com o outro. Utilizando o jogo da capoeira a relação apareceu naturalmente e tínhamos varias ferramentas disponíveis para a interação. Devo reconhecer que houve uma dificuldade para aproveitar todas estas ferramentas que a capoeira oferece: alguns movimentos são difíceis de fazer e é necessário certo domínio técnico para conseguir executar ou criar a partir deles. Isto melhorou ensaio a ensaio, e de forma exponencial (no começo a evolução foi bem mais lenta, mas depois a cada ensaio eu sentia maior crescimento). Por este motivo a prática da "capoeira" nos ensaios era muito importante, pois consegue-se um maior domínio técnico, e uma base para uma criação completa e complexa.

Após esse processo, passamos para o "aikido" como referência para as experimentações. Começamos improvisando livremente sem comprometimento com um texto ou tema, focando somente na exploração das qualidades de movimento e nos tipos de relação entre uke e do nage, fazendo uso principalmente do aproveitamento do impulso e da energia do parceiro.

Da mesma forma que fizemos com a "capoeira", após as primeiras improvisações, os atores registraram em palavras as sensações, imagens e ideias surgidas e conversamos sobre as cenas que poderíamos desenvolver. As principais palavras anotadas foram: altivez (nage), poder (nage/uke), imposição (uke), dissimular (relação), suavidade (nage), sensualidade (uke, especialmente das torções), enfrentamento (relação), conquista (relação), angústia (uke) e dor (uke). A partir destas palavras fomos decidindo quais cenas iríamos trabalhar.

A fim de ilustrar as ideias expostas acima, descreveremos o processo de criação de duas cenas: Ofélia em relação amorosa com Hamlet, Ofélia sendo rejeitada por Hamlet.

Ao improvisarmos a dinâmica de aproveitamento do impulso do parceiro, focando na conexão entre os dois, logo nos veio à mente a conquista e a sedução. Para tanto resolvemos desenvolver uma cena de conquista entre Ofélia e Hamlet, que, embora não esteja no texto de Shakespeare, trouxe elementos importantes para a narrativa. Este é um ponto importante a ser destacado: não nos ativemos estritamente ao texto e, em alguns momentos do processo, desenvolvemos cenas a partir das ideias que surgiram da prática dos atores. Este foi um caso bem típico deste procedimento, uma vez que concebemos uma cena tendo como base as impressões geradas pelas improvisações. Resolvemos investir nessa proposta e criamos esta cena nos apoiando principalmente no aproveitamento de energia de um pelo outro encontrado na relação 
uke/nage. Nesta improvisação experimentamos também como inspiração os diferentes tipos de agarramento presentes no "aikido". Assim, fomos construindo a ideia de dois corpos que se impulsionam, se interseccionam e se aproximam em movimentos circulares e fluidos. A fluência neste improviso mesclou entre liberada e controlada, dependendo do estado emocional e das nuances que se pretendia alcançar nesta relação. De tudo o que foi improvisado, selecionamos os movimentos que consideramos mais interessantes e construímos uma partitura física. Esta cena foi realizada inteiramente sem fala, excepcionando a canção de Ofélia inspirada nas músicas das gueixas e os sons produzidos pela respiração que ajudaram a compor a dramaturgia.

Isabella Leonel, sobre o processo de criação desta cena comentou:

Para desenvolvermos essa cena, utilizamos a técnica do "aikido" proposta pela diretora como uma fonte de inspiração para a movimentação de cena. Aproveitamos o impulso do outro para a movimentação, o que nos permitiu usarmos para a cena movimentos limpos e sem a preocupação em executar uma técnica do "aikido" específica, havendo apenas inspiração em princípios desta arte marcial. Neste caso o princípio que nos baseamos fundamentalmente foi o de aproveitar o impulso corporal do parceiro para a criação. Foi então uma dramaturgia elaborada conjuntamente. Quando pensamos no "aikido" como arte marcial a priori não imaginamos como estímulo para a criação de movimentos em cena. Mas neste projeto de Hamlet, conforme os ensaios foram avançando, foi ficando cada vez mais claro para mim a proposta de que se pode criar muito utilizando o "aikido" para o trabalho no teatro."

Segue abaixo algumas imagens desta cena. No DVD anexo pode-se assistir esta cena.

Imagens de 88 e 89: cena de Ofélia e Hamlet.
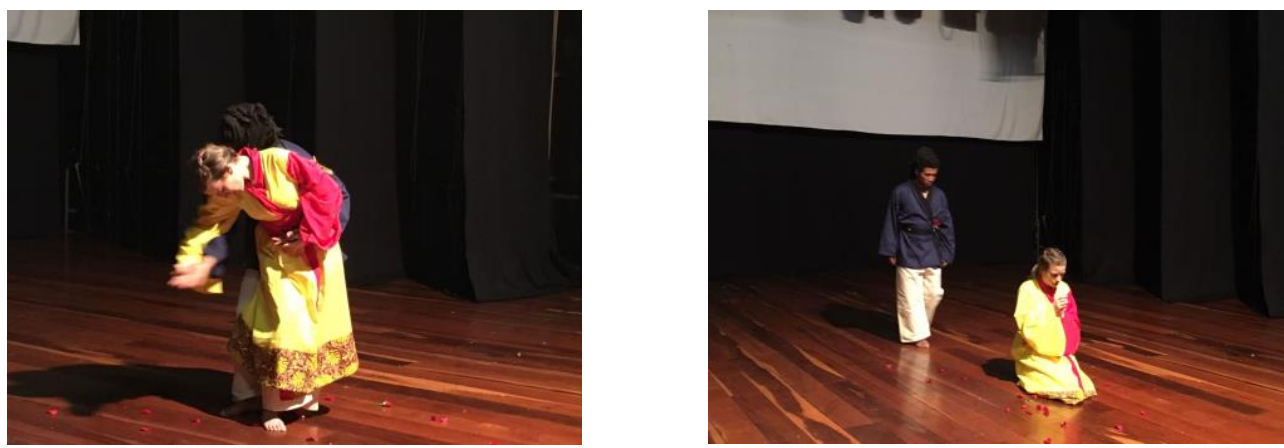

Fontes: arquivo do autor. 
Imagens de 90 a 93: cena de Ofélia e Hamlet.
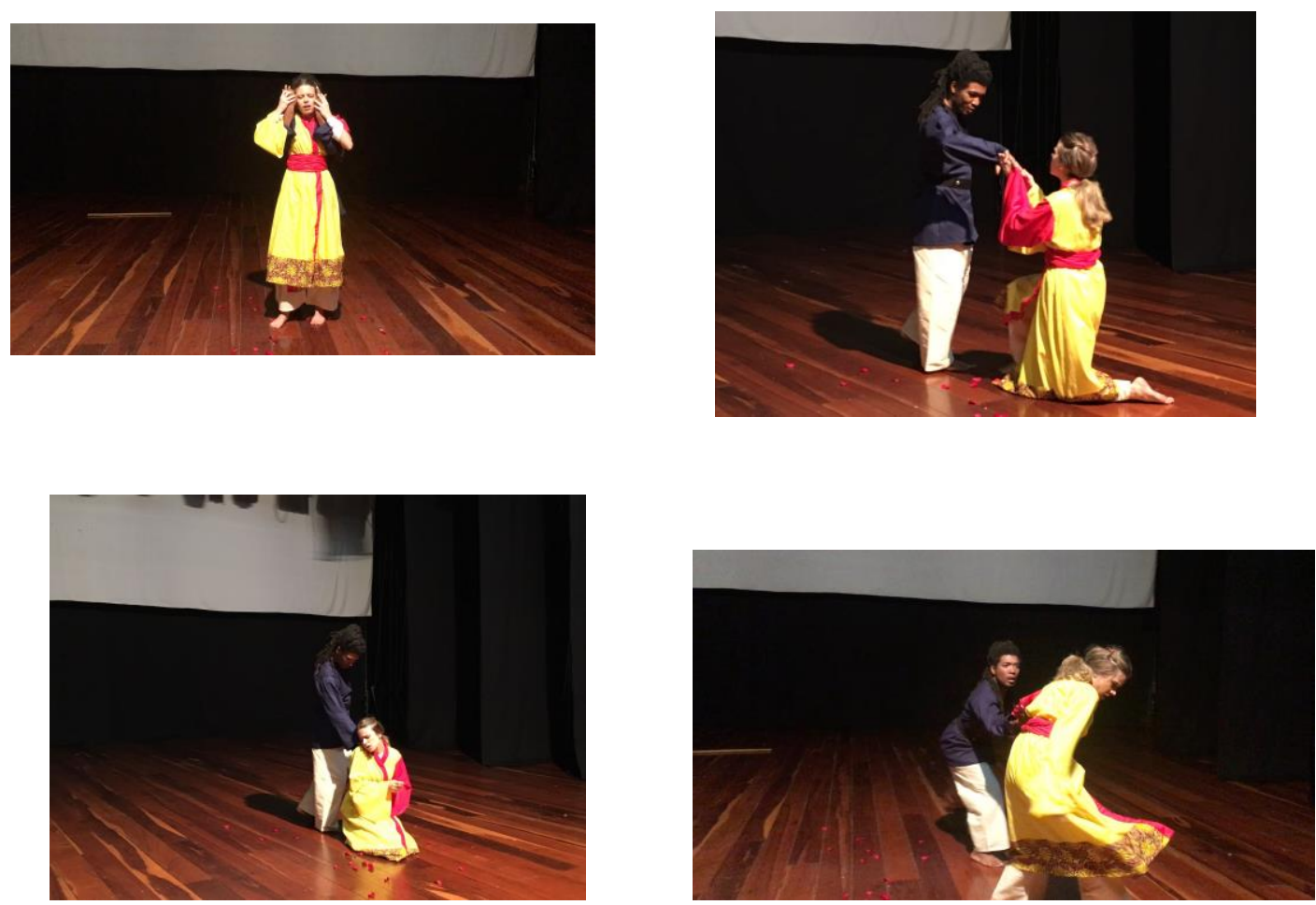

Fontes: arquivo do autor.

Em contraposição a cena descrita acima, experimentamos a cena em que Hamlet rejeita Ofélia quando aquele decide ir à frente com seu plano de vingança. Neste momento, a fim presentificar o conflito proposto por esta cena, recorremos ao jyuwasa. O jyuwasa como já foi exposto é uma dinâmica realizada no "aikido" onde o uke desfere ataques sequenciais e aleatórios sobre o nage e este se esquiva contragolpendo. Para esta cena os ataques do uke sobre o nage se adequaram às circunstâncias e inspiraram as ações da atriz relativas ao desejo de Ofélia de se aproximar de Hamlet. Assim, os contragolpes do nage inspiraram as ações relativas à rejeição de Hamlet, afastando Ofélia de si. Notei que o jyuwaza ajudou aos atores a improvisarem de forma mais fluida e relaxada, porque, dessa forma eles tinham alguns pontos claros onde se apoiar - um deveria atacar e o outro se esquivar como reação ao ataque desferido. Este procedimento de improviso foi filmado para que pudéssemos selecionar os momentos mais interessantes e apropriados à cena. Do material levantado, concebemos a cena. Apesar de nos basearmos em uma cena presente no texto de Shakespeare, optamos por eliminar a fala e manter apenas a respiração sonora dos atores.

Sobre esta experiência a atriz Helena Semedo expôs: 
O jyuwaza foi muito bom para mim na criação da cena e para o aprimoramento da minha postura corporal e do meu tônus. Sinto que fiquei mais envolvida. Inicialmente, tentamos improvisar a partir destas circunstâncias, sem termos essa referência. Fiquei tensa e com dificuldade de jogar com meu parceiro de cena. Quando a Renata propôs que improvisássemos a partir dos princípios do jyuwaza fiquei mais a vontade, mais criativa e consegui me conectar mais com meu parceiro de cena, o Murilo.

No mesmo sentido, o ator Murilo Rocha comentou que:

Inserir o jyuwaza no aquecimento e depois como proposta de criação de cena, ajudou a desenvolver a fluidez dos movimentos que eu estava criando, o que facilitou a improvisação. Além disso, achei que teve uma grande evolução em relação à conexão entre texto, movimento e intenção.

Segue abaixo o texto adaptado da cena entre Hamlet e Ofélia que serviu de inspiração para a criação dos atores:

Hamlet - Não eu não. Eu nunca lhe dei coisa alguma.

Ofélia - Meu Príncipe sabe que e verdade... eis aqui.

Hamlet - Você e bonita? Você e honesta?

Ofélia - O que queres dizer ?

Hamlet - Que se fores bela e honesta, não deves admitir

intimidade entre a tua honestidade e a tua beleza.

Ofélia - Poderia haver melhor companhia para a beleza do que a honestidade?

Hamlet - O poder da beleza transforma a honestidade em meretriz! ... Eu te amei um dia.

Ofélia - O Príncipe me fez acreditar nisso.

Hamlet - Não deverias ter me dado crédito. Eu nunca te amei.

Ofélia - Tanto maior o meu engano.

Hamlet - Vai prum convento. Ou preferes ser geratriz de pecadores?

Não acredite em nenhum de nos.

Ofélia - Oh, céu clemente, ajudai-o!

Hamlet - Já ouvi falar, e muito, de como você se pinta.

Deus te deu uma cara e você faz outra. 
Vai embora! Chega! Foi isso que me enlouqueceu!

Prum convento, vai.

Abaixo segue algumas imagens desta cena.

Imagens 94 e 95: cena Hamlet e Ofélia.
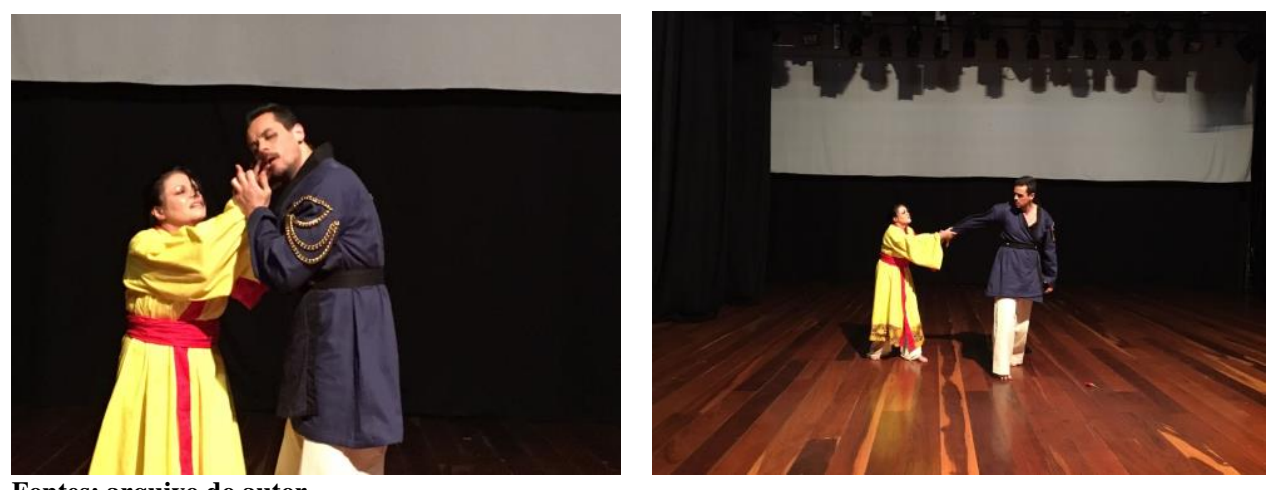

Fontes: arquivo do autor.

O jyuwaza também estimulou a criação de outra cena que foi resultado não de um momento específico do texto de Shakespeare, mas de uma junção de diversas circunstâncias propostas por este autor. Ao ver os atores Ignacio Muñoz e Jefferson Mathias improvisando a partir deste procedimento em um dos treinamentos, vislumbrei um embate psicológico entre Hamlet e Rei Cláudio. Então, propus um improviso em que toda a tensão presente na relação destes dois personagens fosse fisicalizada, como se eles estivessem mental e emocionalmente em combate, embora na realidade este embate fosse mais velado. Para tanto selecionamos alguns textos e circunstâncias presentes na peça para criar esta cena. Abaixo segue o texto dito pelos atores e que inspirou a criação.

CLAUDIO: Sua liberdade implica para todos grande ameaça. Que perigo deixar esse homem solto!

Contudo, não posso ser severo, pois ele é amado pela turba néscia, que não ama com a razão, mas com os olhos. O motivo que me impede de com ele ajustar contas é o grande amor que o devota a plebe, que mergulhando os seus defeitos na afeição, converteria suas cadeias em relíquias.

Contudo, não posso ser severo, pois ele é amado pela turba néscia, que não ama com a razão, mas com os olhos. 
O motivo que me impede de com ele ajustar contas é o grande amor que o devota à plebe, que mergulhando os seus defeitos na afeição, como a fonte que transforma o lenho em pedra, converteria suas cadeias em relíquias." HAMLET: Idiota inerte, alma de lodo, Vivo na lua, insensível à minha própria causa, E não sei fazer nada, mesmo por um rei Cuja propriedade e vida tão preciosa Foram arrancadas numa conspiração maldita. Sou então um covarde? Quem me chama canalha? Me arrebenta a cabeça, me puxa pelo nariz, E me enfia a mentira pela goela até o fundo dos pulmões? Hein, quem me faz isso? Pelas chagas de Cristo, eu o mereço! Pois devo ter fígado de pomba, sem o fel Que torna o insulto amargo, Ou já teria alimentado todos os abutres destes céus Com as vísceras desse cão. Ah, vilão obsceno e sanguinário! Perverso, depravado, traiçoeiro, cínico, canalha! Ó, vingança! Mas que asno eu sou! Bela proeza a minha. Eu, filho querido de um pai assassinado, Intimado à vingança pelo céu e o inferno, Fico aqui, como uma marafona, Desafogando minha alma com palavras.”

A respeito desse processo o ator Nacho Munoz comentou: "Utilizar o jyuwaza foi muito positivo. As primeiras vezes foram cansativas e difíceis, mas me ajudou muito a deixar o racional de fora e seguir o que pede o corpo em cada momento." Segue abaixo algumas imagens desta cena. No DVD anexo pode-se assistir esta cena.

Imagens 96 e 97: cena Hamlet e Cláudio.
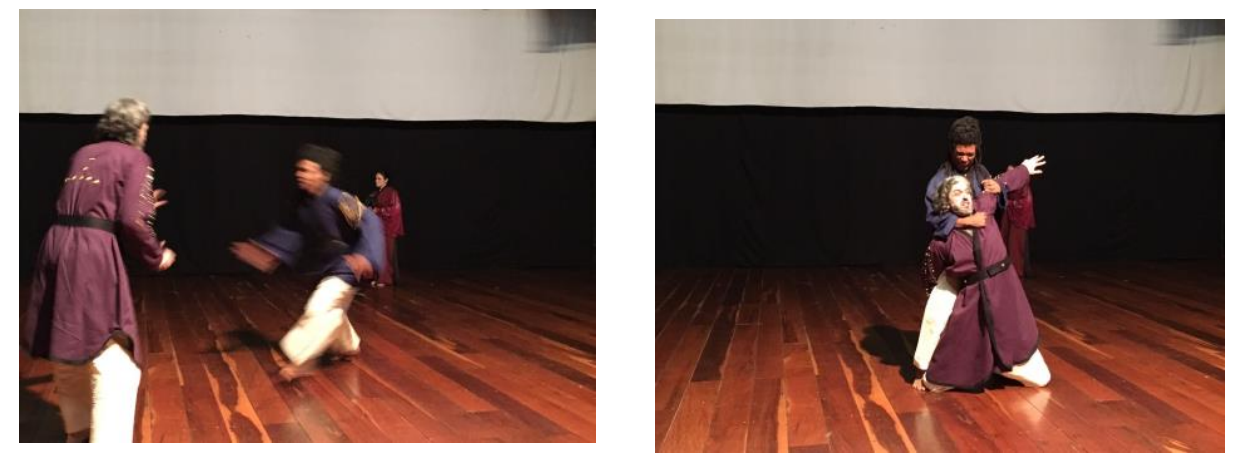
Após um período de trabalho prático desenvolvendo cenas a partir de uma ou outra arte marcial, resolvemos, em uma das cenas, utilizar as duas artes conjuntamente como estímulos para a criação. Escolhemos a cena entre Hamlet e Gertrudes, em que ele a confronta em seus aposentos sobre sua relação com Cláudio e com o falecido pai até o ponto em que o fantasma retorna para conversar com o filho. Nesta cena os elementos do "aikido" e da "capoeira" foram sendo utilizados durante o improviso de acordo com o que mais se conectava com o que acontecia na prática. Esta conexão foi se dando durante a improvisação em diálogo corporal entre os atores. Mantivemos parte do texto de Shaskespeare na medida em que sentíamos necessidade para a composição da dramaturgia. Pode-se observar na personagem Gertrudes tanto elementos do "aikido" como a postura semelhante a do nage ao confrontar o filho e o leque como uma extensão do braço a semelhança da tegatana, mão espada, quanto elementos da "capoeira" como movimentos inspirados nas esquivas e na ginga ao tentar escapar da ira do filho. Da mesma forma, vemos em Hamlet uma mescla desses elementos como a postura do nage ao iniciar o diálogo com a mãe, o assassinato de Polônio com uma técnica de jo, o uso de apresamentos pelos punhos e pescoço típicos do "aikido" e o princípio da ginga ao pressionar a mãe com as fotos e ao interagir com o fantasma. $\mathrm{O}$ som do agogô foi utilizado também para a criação da sonoplastia da cena durante a entrada do fantasma.

Abaixo, segue o texto adaptado que compôs a dramaturgia:

HAMLET: (Fora) Minha mãe, minha mãe, minha mãe!

Olá, minha mãe, de que se trata?

RAINHA: Hamlet, ofendeste muito teu pai.

HAMLET: Mãe, a senhora ofendeu muito meu pai.

RAINHA: Cuidado, respondes com uma língua tola.

HAMLET: A senhora pergunta com uma língua indigna.

RAINHA: Como? O que é isso, Hamlet. Esqueceste quem eu sou?

HAMLET: Não, pela cruz, não esqueci.

A senhora é a Rainha, esposa do irmão de seu marido;

E - antes não fosse! - é minha mãe. 
RAINHA: Muito bem, vou te colocar diante de pessoas capazes de falar contigo.

HAMLET: Sente aí e não se mova;

Não vai sair daqui antes que eu a ponha diante de um espelho

Onde veja a parte mais profunda de si mesma.

RAINHA: Que pretendes fazer? Vais me matar? Socorro, socorro, aqui!

POLÔNIO: (Atrás da tapeçaria.) Olá! Socorro! Socorro! Socorro!

HAMLET: (Puxando o florete.) Que é isso? Um rato? Morto!

RAINHA: Ai de mim, que fizeste?

HAMLET: Ora, eu não sei. Quem é; o rei?

RAINHA: Oh, que ação sangrenta e absurda!

HAMLET: Ação sangrenta! Quase tão má, minha boa mãe,

Como matar um rei e casar com o irmão dele.

HAMLET: (Levanta a tapeçaria e olha Polônio.) Tu miserável, absurdo, intrometido idiota - adeus! Eu te tomei por um teu maior. Aceita teu destino. (À Rainha.) Calma e senta aí!

RAINHA: Que foi que eu fiz pra tua língua vibrar Contra mim com esse ódio todo?

HAMLET: Olha aqui este aqui, e este. (Mostra imagens que se referem ao pai e ao tio.) Retratos fiéis de dois irmãos. Veja a graça pousada neste rosto. Vê agora o que se segue; Aqui está o outro marido, como uma espiga podre, contaminando o irmão saudável. A senhora tem olhos? E deixa de se alimentar nesta montanha límpida 
Para ir engordar num lamaçal? Hei! Tem ou não tem olhos?

RAINHA: Oh, Hamlet, não fala mais.

Você vira meus olhos pra minha própria alma;

E vejo aí manchas tão negras e indeléveis

Que jamais poderão ser extirpadas.

HAMLET: É, mas viver

No suor azedo de lençóis ensebados,

Ensopados na corrupção, arrulhando e fazendo amor

Numa sentina imunda...

RAINHA: Chega, Hamlet!

HAMLET: Um assassino covarde,

RAINHA: Basta!

HAMLET: Um rei só de remendos e retalhos... (Entra o

Fantasma.)

(Ao Fantasma.) Que espera de mim,

HAMLET: O senhor vem repreender o filho negligente

Que deixou escapar a hora e a paixão

Sem executar sua ordem terrível?

Me diz!

RAINHA: O que é que você tem,

Fixando assim seus olhos no vazio,

E conversando com o ar incorpóreo?

HAMLET: (Ao Fantasma.) Não olhe assim pra mim,

Pois esse apelo piedoso pode me demover

Do meu rígido intento.

RAINHA: Pra quem você diz isso?

HAMLET: A senhora não vê?

RAINHA: Não vejo nada:

HAMLET: Meu pai, vestido como vivia!

(Sai Fantasma.) 
RAINHA: É teu cérebro que forja essa visão;

HAMLET: Não é loucura

O que eu proferi; é só me pôr à prova

Que repito, palavra por palavra,

RAINHA: Oh, Hamlet, você partiu meu coração em dois.

HAMLET: Pois joga fora a pior parte dele,

E vive mais pura com a outra metade.

Boa-noite. Mas não vá pra cama de meu tio;

Simula uma virtude, já que não a possui.

Segue abaixo algumas imagens desta cena. No DVD anexo pode-se assistir esta cena.

Imagens de 98 a 101: Hamlet e Rainha.
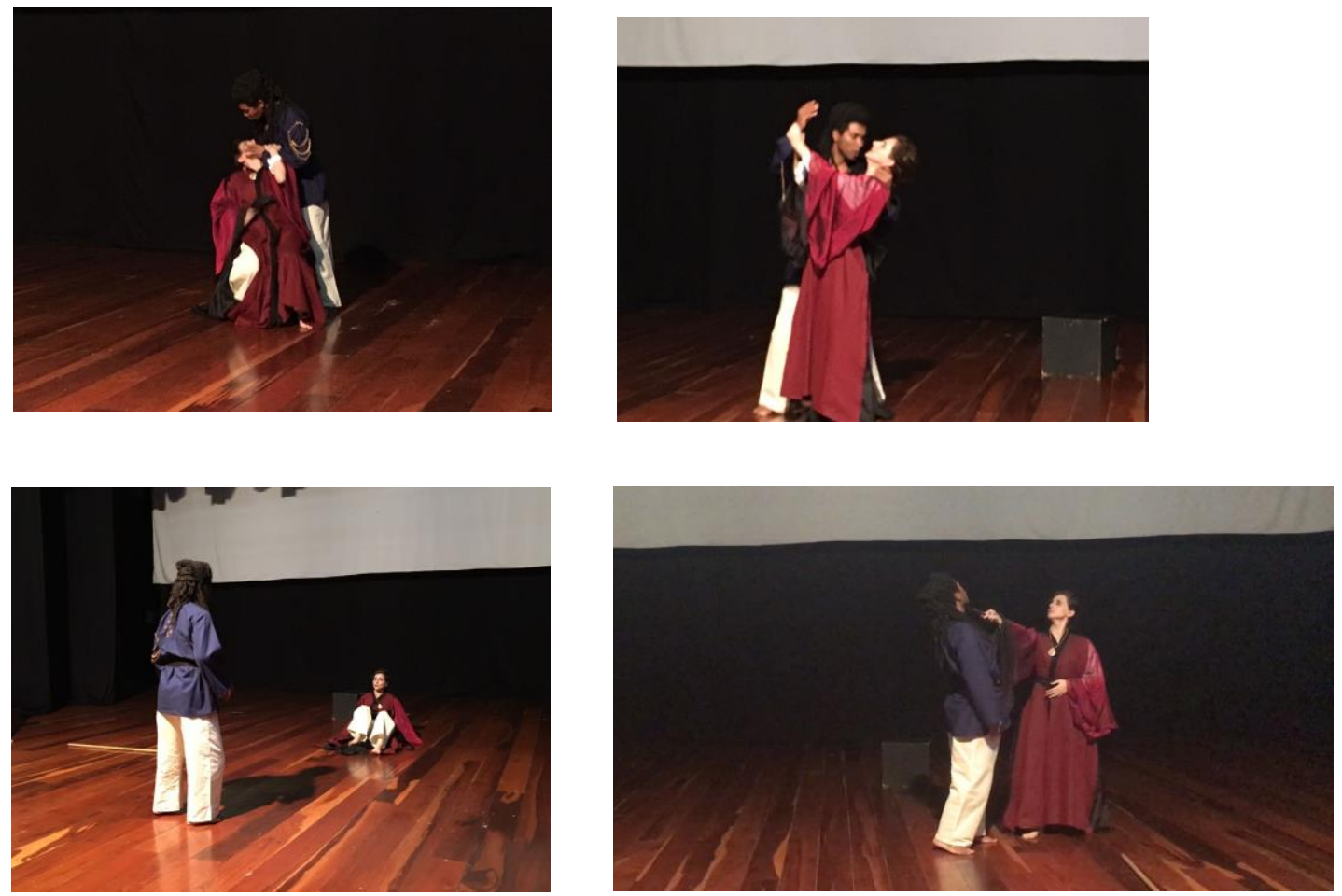

Fontes: arquivo do autor.

Apreende-se, pelo exposto que, o que objetivamos nesta etapa da investigação foi, por meio de improvisações ancoradas nos referenciais teóricos e técnicos e nos estímulos artísticos aqui apresentados, desenvolver a comunhão e a sintonia entre os atores, fazendo com que eles produzissem um material que servisse para a criação de 
uma dramaturgia construída quase que inteiramente pelas afetações corporais e pelos encontros estabelecidos durante a prática.

\subsubsection{A ritualidade}

Nesta pesquisa procuramos investigar de que forma os elementos presentes no "aikido" e na "capoeira" podem ajudar na preparação e no trabalho criativo objetivando a construção de uma dramaturgia do ator. Anteriormente nos preocupamos em apresentar o treinamento com os atores visando o aprimoramento individual e relacional e a estimulação criativa por meio das técnicas e princípios presentes nas artes marciais citadas. Todo esse processo foi conduzido a partir da noção de corpo como uma estrutura composta de partes física e psíquica que se relaciona com o mundo a volta e que, a partir dessa relação, vai se transformando constantemente.

Como continuidade da pesquisa, pretendemos nessa parte expor de que forma alguns elementos do contexto cultural destas artes marciais, mais especificamente os relacionados à ritualidade, serviram de recursos para a ampliação e o aprofundamento dos procedimentos para o trabalho com os atores. Acreditamos que, para este trabalho, é importante a compreensão de que cada movimento apreendido ou cada princípio seguido faz parte de um todo composto de elementos culturais e históricos que justificam e fundamentam cada atitude, cada regra, cada técnica destas artes. Portanto, conhecer apenas a técnica e restringir o processo de preparação e criação a ela seria como querer conhecer o iceberg apenas pela ponta. Além disso, a partir da ideia de que a relação do homem com o mundo que o cerca é inevitável, entendemos que participar de um processo de imersão em um universo cultural tão complexo e rico é uma forma de ampliar o potencial criativo do ator uma vez que, ao se relacionar com todo esse contexto na prática, com o corpo todo, ele passa a fazer parte de sua vida e, por consequência de seu trabalho artístico. Portanto, nos parece lógico que estes aspectos histórico-culturais relativos à ritualidade destas artes marciais apoiem o desenvolvimento do treinamento e da criação da dramaturgia nesta pesquisa.

Tratemos agora diretamente de como vemos a ritualidade inserida na prática do "aikido" e da "capoeira".

Muitas são as definições de ritual. Os rituais são muitas vezes entendidos como práticas ligadas ao misticismo, à religião e à arte, mas também estão conectados às rotinas bem marcadas do cotidiano que auxiliam no bem estar pessoal e a eventos sociais como cerimônias e comemorações que na maioria das vezes não carregam 
qualquer intenção religiosa ou mística. Analisando essas práticas, seja em um ambiente religioso, social ou em nosso dia-a-dia, podemos perceber um ponto em comum entre todas elas, é a repetição de ações e códigos criados muito antes de nós e que são perpetuados de geração em geração. Acerca dessas repetições de padrões, Schechner (2012, p. 94), quando discorre sobre as representações, explica que estas manifestações "seja nas artes cênicas, no esporte e na vida cotidiana- consistem em gestos e sons ritualizados, inclusive quando pensamos que estamos sendo espontâneos e originais". Esta repetição de comportamento nos remete, portanto, a aspectos e contextos culturais que envolvem nosso cotidiano, incluindo os ritos nos quais tomamos parte.

A cerca da conexão com a tradição cultural, identificamos um ponto de contato entre jogo e ritual, uma vez que ambos são resultados do contexto social em que foram criados, refletindo formas de se relacionar com o mundo. Como exemplo, podemos citar o jogo de bola maia, em que uma bola de ferro era lançada pelo jogador em um círculo delimitado localizado no alto do campo. Este jogo não tinha fins exclusivamente esportivos, mas também carregava elementos ritualísticos. Para este povo este jogo tinha como função contribuir para a manutenção da ordem cósmica e para a regeneração da vida. Outro exemplo, mais contemporâneo e relacionado com o universo pesquisado, é o Oshiruka Manju, um jogo japonês jogado nos dias de muito frio para se aquecer. Os participantes devem se empurrar pelas costas enquanto cantam Oshikura Manju osarete nakuna, que significa "Manju não chora mesmo quando é empurrado". Percebemos nos jogos descritos, não apenas a preocupação com o lúdico, mas simbolizações de elementos sociais presentes na cultura em que estão inseridos. A respeito disso, Gonçalves explica que:

(...) da simbolização dos rituais sociais, queremos sublinhar que a sua compreensão só é possível em estreita ligação com a tradição cultural total de que fazem parte, o que supõe um sistema de significações e de 'códigos culturais' através dos quais os homens comunicam, perpetuam e desenvolvem o seu conhecimento e as atitudes em relação à vida. A ordem simbólica e a tradição cultural são integrativas, porque asseguram a comunicação dos atores sociais e a perenidade das suas interações. (GONÇALVES, 1999, p. 337-338)

Temos, portanto, que todos os rituais, assim como os jogos, operam a partir de alguns códigos e símbolos que tem como base os aspectos culturais do grupo e que, por meio deles, os participantes interagem e se expressam. 
A diversidade de tipos de rituais é tão grande quanto à diversidade cultural, uma vez que ambos estão conectados intrinsecamente. A esse respeito, Victor Turner defende:

Que em matéria de religião, assim como de arte, não há povos "mais simples", há somente povos com tecnologias mais simples do que as nossas. A vida "imaginativa" e "emocional" do homem é sempre, e em qualquer parte do mundo, rica e complexa. (TURNER, 1974, p. 15)

Segue ainda expondo que:

Não é inteiramente correto falar da "estrutura de urna mentalidade diferente da nossa". Não se trata de estruturas cognoscitivas diferentes, mas de urna idêntica estrutura cognoscitiva, articulando experiências culturais muito diversas. (TURNER, 1974, p. 15)

Esta estrutura cognoscitiva lembrada por Turner se refere ao processo de assimilação e armazenamento do conteúdo informacional e que acabam por gerar padrões de ações física e mental. Podemos dizer, dessa forma, que os seres humanos, em sua maneira mais básica de se relacionar com o entorno, são iguais, diferindo-se apenas a partir dos elementos presentes à volta. É neste contato com o mundo que as diferenças culturais vão surgindo. Esta ideia dialoga com o defendido por Noe, 1996, sobre a plasticidade da consciência, segundo o qual a natureza do ser humano é plástica e moldável por suas vivências afetando sua forma de ver o mundo e de se relacionar com ele. Por isto é fácil compreender como o contexto em que viviam os negros escravos e seus descentes desencadeou o processo que deu origem à "capoeira", uma arte onde identificamos elementos africanos transformados pela realidade brasileira. Da mesma forma, analisando os fundamentos do "aikido" e sua estética, identificamos os elementos da cultura japonesa que contribuíram para sua formação. Temos, por conseguinte, que as duas artes aqui estudadas estão impregnadas do contexto em que foram criadas, trazendo para os dias de hoje uma memória que atravessa o tempo e que marca o corpo. Não vemos simplesmente formas de defesa pessoal, mas um reflexo da maneira desses povos se relacionarem com o mundo a volta e de agirem diante das adversidades. Assim, estudando os corpos dos praticantes destas artes ao longo do tempo, percebemos uma modulação específica e uma historia sendo contada a cada movimento. Percebemos por consequência, ao assistirmos uma demonstração de "aikido" ou um jogo de "capoeira", relações sendo estabelecidas e diálogos sendo criados nas movimentações dos corpos e na relação com os elementos que os cercam. A 
partir do exposto, comparando o "aikido" e a "capoeira", percebemos que, em razão das diferenças entre os contextos que as circundam, notamos nas corporalidades de ambas, características contrastantes envolvendo o uso do tônus, a forma de se deslocar pelo espaço, a presença ou a ausência de musicalidade, o contato físico, a forma de tratamento entre as pessoas, as regras que definem o andamento da prática e assim por diante.

Schechner (2012, p. 94) também explica que os rituais são "memórias coletivas codificadas em ações" e que "o jogo e o ritual levam as pessoas a uma "segunda realidade', a parte da vida comum." De acordo com este autor, as pessoas são transformadas tanto pelo jogo como pelo ritual, seja de forma mais durável ou mais temporal. A autotransformação, a conexão com outra realidade e com a memória, apontadas por Schechner, 2012, aparece em pensamentos de diferentes culturas e áreas. Carlos Byington $^{38}$, psiquiatra e analista jungiano, explica que ritual tem a finalidade de concentrar energia para manter a memória. Ou seja, o passado é evocado pela concentração deste elemento de tão difícil definição, mas tão mencionado em quase todas as áreas científicas: a energia. O passado é revivido a cada prática por meio dessa fonte que nos anima e que não vemos, mas que percebemos com todo nosso corpo. Gustavo Pinto, monge budista explica ritual, a partir da visão do Budismo, como sendo a forma de nos alinharmos com as dimensões invisíveis de modo que elas possam fluir através de nós, sobre tudo e todos em torno. Mais uma vez a conexão com o que não está diretamente palpável por nós é lembrada nestas definições. Este estado diferenciado e esta conexão com algo que está além do que vemos e tocamos são alguns dos efeitos dos rituais. Entendemos também, do que foi exposto, que o ritual tem como finalidade sua própria dinâmica, ou seja, pode ser entendido como uma praxis, como algo que se basta por si mesmo e não vislumbra nenhum outro produto ou obra que não seja sua própria atividade. Não praticamos os rituais para que algum outro produto seja gerado disso, mas o praticamos pela experiência em si, para nos sentirmos transportados para um novo estado, nos conectando com uma dimensão diferente da que vivemos cotidianamente. Este pode ser destacado como outro ponto de coincidência do ritual com os jogos, pois estas duas manifestações culturais têm o poder de instaurar um

38. Este trecho foi elaborado a partir de uma palestra ministrada por Carlos Byington no Teatro Escola Macunaíma por ocasião da Semana de Planejamento. 
estado diferente do comum, suspendendo momentaneamente as atividades cotidianas e corriqueiras.

Em todas as conceituações aqui apresentadas sobre ritual encontramos pontos de conexão entre elas que são: relação com a energia e o invisível, preservação da memória, ligação com os aspectos culturais, imanência e transformação dos envolvidos durante o processo, presença de códigos e símbolos específicos e estruturação. Quando nos referimos à estruturação e à presença de códigos, logo nos remetemos às regras que dão ordem à prática. Da mesma forma que os jogos, os rituais também seguem uma organização previamente definida, que não é absolutamente rígida, mas que deve ser obedecida pelos participantes, a fim de preservar a harmonia do grupo e o andamento da atividade. Entretanto, existe uma diferença entre eles, uma vez que o ritual, para Schechner, 2012, tem um aspecto de seriedade maior e a contundência da autoridade. Segundo ele o jogo é mais solto e flexível enquanto o ritual é mais coercitivo e rígido. Segue explicando que "o jogo é um estado de ânimo, uma atividade, uma erupção espontânea. Às vezes está sujeito às regras, às vezes é mais livre. Tudo o invade" 39 (SCHECHNER, 2012, p. 150-151). Entende-se, portanto que, enquanto no ritual a liberdade individual não é tão evidente e as regras têm um peso e uma rigidez maior, dando menos espaço para os envolvidos se expressarem pessoalmente, no jogo permitese uma criatividade maior, pois, ainda que haja regras, os jogadores podem atuar mais livremente. É interessante o termo “erupção espontânea”, utilizado por este autor, uma vez que faz uma síntese da potência de um jogo: é espontâneo porque depende da forma subjetiva de cada um em se relacionar com as regras e é uma erupção porque dispara uma dinâmica bastante intensa e potente enquanto está se desenvolvendo. Em proporção e qualidade diferentes, podemos observar esta mesma erupção nos rituais, uma vez que o envolvimento dos participantes cresce gradualmente durante o rito até alcançar o ápice.

Tratando especificamente da "capoeira" e do "aikido", identificamos em suas práticas ações, regras e códigos culturais, originadas de um contexto afro-brasileiro e japonês, respectivamente, que transportam os praticantes para um universo diferente do

39. "El ritual tiene un aspecto de seriedad, la contundência de la autoridade. El juego es más suelto, más permisivo, indulgente precisamente em aquellas áreas em las que el ritual es coercitivo, flexible donde el ritual es mas rígido. (...) Es um estado de ánimo, uma actividad, una erupción espontânea. A veces está sujeto a reglas, otras veces es muy libre. Todo lo invade." (SCHECHNER, 2012, p. 150, 151) 
cotidiano, colocando-os em outro estado. O início de uma roda de "capoeira", o posicionamento dos instrumentos, a música, os golpes e as esquivas, o abadá ${ }^{40}$ e a relação entre os participantes, refletiam em suas origens e refletem ainda hoje a forma dos capoeiristas se relacionarem com o mundo e de se expressarem. Da mesma forma, no treino de "aikido" com seu início cerimonioso e solene ao kamiza, o silêncio durante a atividade, a reverência com a curvatura da coluna entre os participantes, a espera pela autorização do Sensei em seiza, o $d o g i^{41}$ e a complementariedade entre uke e nage, trazem uma visão de mundo e um tipo de relação entre as pessoas que expressam elementos importantes da cultura japonesa. Pelo exposto, comparando estas duas práticas, percebemos que ambas possuem características muito diferentes uma da outra e, por isso, tem o poder de instaurar estados totalmente diversos, afetando de forma particular os envolvidos. Cada um desses elementos apontados, que tiveram início há muito tempo e que foram sendo ensinados e transformados ao longo dos anos, traz uma carga cultural e de significados, que ao serem colocados em prática nestes rituais, transportam os participantes para uma atmosfera característica de cada uma dessas culturas.

Tratando dessas diferenças ritualísticas, podemos citar, por exemplo, as formas de cumprimento. No "aikido", que segue as tradições japonesas, o cumprimento é formal e cerimonioso. O ojigi é o nome dado para esta reverência que é feita em situações várias do dia a dia como no encontro de pessoas e em uma apresentação, como forma de pedir desculpas e de despedir-se. Neste cumprimento é necessário inclinar-se em direção à pessoa que se quer cumprimentar, sem olhá-la nos olhos, com os braços ao longo do corpo e os pés paralelos - no caso dos homens -, ou totalmente juntos - no caso das mulheres. Ao se realizar o ojigi se diz algumas expressões que devem ser adequadas a cada momento, mas que não serão expostas aqui por não serem o foco deste trabalho. Durante os treinos de "aikido" este cumprimento é feito:

40. ABADÁ vem do iorubá agbada, vestimenta larga e comprida, até o tornozelo, aberto dos lados, com bordados no pescoço e no peito, usada por homens. Na capoeira se refere a vestimenta (calça típica e camiseta) utilizada pelos capoeiristas durante a roda.

41. Vestimenta utilizada pelos praticantes de arte marcial japonesa. 
a) no início na posição de seiza - sentando-se sobre os joelhos e calcanhares -, coletivamente em respeito ao kamiza ${ }^{42}$ e ao Sensei;

b) entre os parceiros logo antes de começar a treinar;

c) ao final de cada prática, também em seiza em respeito ao kamiza, ao sensei e aos parceiros de treino.

De modo geral, nos treinos de "aikido", quando os companheiros se cumprimentam, dizem as palavras Onegai Shimasu que quer dizer ao grosso modo "Você me permite treinar com você?". E para encerrar a parceria dizem normalmente Arigatou gozaimashita ou Arigatou gozaimasu que significa obrigado. Estas traduções são bem simplistas, pois suas palavras comunicam muito mais do que foi aqui apresentado, sendo difícil traduzir ao pé da letra. No caso da expressão Onegai Shimasu, por exemplo, shimasu vem de suru que significa fazer. Negai significa orar, ter esperança em algo. O "O” no início da expressão é o honorífico que dá um tom respeitoso e polido como já vimos em $O$ Sensei, por exemplo. No momento do treino, ao dizer essa expressão, a intenção é pedir a alguém autorização para treinar com ele. $\mathrm{Na}$ cultura japonesa o significado desta expressão varia de acordo com a situação, mas não nos alongaremos nestes detalhamentos e nos limitaremos ao que é praticado nos treinos de "aikido".

Diferentemente do "aikido", na "capoeira" encontramos um tipo de cumprimento mais informal. Os dois parceiros, logo antes de começarem o jogo, ficam em pé ou agachados um em frente ao outro, batem as mãos de forma simples, descontraída e mantendo o contato de olhos. É comum também fazerem uma reverência ao berimbau antes de começarem a jogar, em um movimento próximo do chão. $\mathrm{Na}$ sequência da roda, ao comprar o jogo, um simples cumprimento de mão já é suficiente para dar seguimento ao jogo. Ao se cumprimentarem, via de regra, não se verbaliza nada, limitando-se ao toque das mãos conforme explicado anteriormente, com exceção do termo "Iê" que é uma forma de cumprimento utilizado em alguns momentos da roda como para saudar, para pedir licença e para chamar atenção para si. Além disso, no

42. Kamiza é o termo utilizado para designar o local mais importante de uma sala ou espaço. Nos casos do aikido o kamiza reúne os símbolos mais importantes para esta arte marcial como as imagens do fundador do aikido e seus descendentes e o kanji de aikido. 
cumprimento da "capoeira", observa-se sempre um tom sorridente e descontraído, diferentemente da seriedade e da formalidade do ojigi.

Consideramos importante tratar do cumprimento como ilustração, pois neste rito simples identificamos muitos aspectos culturais que implicam na forma de perceber o mundo e se relacionar com ele. Percebemos por exemplo, a diferença social entre o homem e a mulher, a formalidade nos contatos sociais, a descontração ou seriedade da prática, a rigidez ou a flexibilidade da forma, dentre outras coisas que marcam uma cultura e direcionam comportamentos. Os ritos que vemos no "aikido" e na "capoeira" são frutos dessas culturas que, como aponta Schechner, 2012, foram passados de geração a geração. E como cada um desses elementos que compõem os rituais vem carregado de significado. Quando nos inserimos neles, nos sentimos afetados em todo o nosso corpo pela atmosfera instaurada.

Outro aspecto que diferencia e caracteriza essas ritualidades é a sonoridade, questão que já foi apontada em capítulos anteriores. Enquanto no "aikido" vigora na maior parte do tempo o silêncio, na "capoeira" é a música que dá o tom do que vai ser feito. Todavia, é importante ressaltar que, não é porque não existe música no treino do "aikido" que não há uma sonoridade característica se fazendo presente. Elementos como as frases proferidas durante os cumprimentos, o kiai ${ }^{43}$, as palmas executadas durante os ojigis, os momentos de silêncio, os sons das quedas nos tatames e a respiração, criam uma textura sonora totalmente diferente da expressividade sonora afro-brasileira regida por atabaques, berimbau, pandeiro e agogô. Além disso, o "aikido" tem uma forte conexão com o kototama que, conforme já foi exposto, são sons que procuram alterar o estado energético do corpo. Todos esses elementos sonoros e musicais presentes nesses rituais nos afetam sensorialmente, o que faz com que os participantes se sintam transformados e transportados para outra dimensão.

Assim como os aspectos e ações acima apontados, diversos outros carregados de códigos e símbolos compõem estas práticas, dando a elas características próprias. O batismo da "capoeira", por exemplo, é considerado simbolicamente o momento de entrada para esta comunidade, o momento em que o praticante se coloca para o grupo, se sujeitando às condições impostas como o jogo com um graduado até a queda e com

43. Som realizado pelo praticante durante a expiração, em sincronia com a execução de um golpe. Uma das finalidades do kiai é dar potência ao golpe e distensionar a musculatura. 
um parceiro de batismo. A troca de graduação para o "aikido" tem uma função semelhante, pois é o meio pelo qual o aikidoista gradualmente vai se inserindo na comunidade do "aikido". Estes dois eventos podem ser considerados como ritos de passagem, pois, por meio deles, os participantes passam de uma fase a outra, sofrendo transformações individuais e sociais, uma vez que se apresentam perante a comunidade e são vistos por ela de uma forma diferenciada. A respeito disso, Gonçalves explica que:

Esses rituais cíclicos e iniciáticos (...) marcam os momento vitais de transição, que todas as sociedades ritualizam e simbolizam publicamente com práticas apropriadas, a fim de inculcar nos membros da comunidade os valores individuais e comunitários e o sistema de símbolos reatualizados pelos ritos. (GONÇALVES, 1999, p. 340)

Dois são os elementos apresentados por este autor e que se conectam com o objeto de estudo em questão: a ciclicidade e a reatualização. As duas artes marciais ora investigadas realizam estes rituais em ciclos, retomando o mesmo ponto de tempos em tempos, a fim de reafirmar e trazer para o presente, símbolos importantes construídos ao longo de sua história.

Outro exemplo de evento que apresenta aspectos importantes dessas ritualizações são as festas de confraternização promovidas entre os praticantes de ambas as artes marciais, uma vez que elas contribuem para a instauração da comunhão e da sintonia entre os indivíduos, fortalecendo a ideia de grupo. Acerca desse estado de pertencimento possibilitado pelo ritual, Schechner explica que:

Os rituais são mais que estruturas e funções; podem ser também uma das experiências mais poderosas que a vida pode oferecer. (...) As pessoas se sentem com seus camaradas; as diferenças pessoais e sociais são postas de lado. (SCHECHNER, 2012, p. 120)

Continua ainda explicando que o ritual é "para as pessoas uma forma de se conectar com o coletivo, de recordar ou construir um passado mítico, de construir a solidariedade social e de formar ou sustentar uma comunidade" (SCHECHNER, 2012, p. 147). Percebemos este aspecto da coletividade, do conjunto e da memória em todos os elementos que compõem estas artes, fortalecendo a ideia de comunidade apresentada por Schechner.

Complementando o fenômeno exposto acima, Schechner explica ainda que a prática de ritual pelos humanos remonta a milhares de anos e tem como função biológica operar: 
Para facilitar a coordenação tanto organísmica como interorganísmica. Tal coordenação é necessária para elaborar respostas coerentes, coorporativas, com motivações e impulsos comuns, para a consecução de algum efeito ou tarefa que não poderiam ser realizados por cada um atuando sozinhos. (SCHECHNER, 2012, p. 106)

Este "fazer juntos" para dar conta de algo que não se conseguiria sozinho é facilmente percebido na história da "capoeira" quando os escravos e seus descentes decidiram se unir para resistir e sobreviver à opressão sofrida dando início ao que viria a ser a "capoeira”. A “capoeira” é, portanto, uma manifestação coletiva criada por pessoas que viveram em contextos culturais semelhantes e que por meio de uma expressão artística e marcial exteriorizaram suas necessidades, desejos e impulsos comuns. Da mesma forma que a "capoeira", a criação do "aikido" foi baseada em artes marciais que tiveram como objetivo a satisfação de uma necessidade coletiva a partir dos problemas que vivenciavam na época como as guerras entre feudos no Japão. Além disso, o fundador, ao elaborar o "aikido", diante do que vivenciava na guerra da qual participou, estava desejoso de uma prática que colocasse as pessoas em sintonia consigo mesmas, com o próximo e com o universo. Por fim, O Sensei sempre ressaltou a importância da presença de parceiros de treino, com os quais é possível o desenvolvimento e a evolução constante. Durheim corroborando este entendimento argumenta ainda que os rituais não são apenas ideias ou abstrações, mas ao contrário, são as ideias encarnadas (SCHECHNER, 2012).

Tendo em vista tudo o que foi apresentado sobre o "aikido" e a "capoeira", pode-se perceber que estamos tratando de duas ritualidades bastante distintas. Entretanto, se as olharmos com mais atenção descobriremos diversos pontos de semelhança que acaba por as aproximarem de algum modo. Notamos estas aproximações na necessidade de ritualização do início e do término, nos cumprimentos durante a prática, na fluidez do jogo, na presença de uma vestimenta específica para estas ocasiões, na hierarquização pelo tempo de treino, no respeito ao mestre e na congregação dos participantes. É possível notar assim, que as necessidades das pessoas inseridas nestas culturas são muito parecidas, sendo que cada uma as satisfaz por meios específicos conectados ao mundo em que vivem. Este ponto nos remete ao exposto por Turner quando ele trata da riqueza dos simbolismos nos ritos, das diferenças culturais e das estruturas cognitivas idênticas, pois nos dois casos apresentados podemos observar atitudes e ações diversas, mas criadas para a satisfação de necessidades que conectam 
ambas as culturas, quais sejam, o encontro, o pertencimento e o contato entre as pessoas.

Convém ainda trazer outro aspecto abordado por Schechner, 2012, que diz respeito aos diferentes tipos de ritual, a fim de entendermos em qual se inserem cada uma destas artes marciais. Este autor apresenta dois tipos: o sagrado e o secular. O sagrado diz respeito a todos os rituais relacionados à religião, a evocação do sobrenatural, do invisível, seja na figura de um Deus ou de elementos da natureza como rios e pedras. Já os rituais seculares são todos os outros que não se ligam ao religioso e ao místico, mas que estão presentes na vida cotidiana, nos esportes, nas cerimônias de Estado, dentre outros. Todavia, ele esclarece que esta divisão, algumas vezes, é complexa e nebulosa, em que alguns rituais mesclam elementos dos dois tipos, conectando o religioso e o social.

A respeito do tipo de ritual que vemos na "capoeira", pensamos ser apropriado iniciar citando a famosa frase de Nietzche, 1996: "Não acredito em um Deus que não saiba dançar”. A “capoeira" não é religião, mas possui um forte caráter ritualístico e de celebração, como se estivesse sendo evocado a todo instante a ancestralidade. Além disso, desde suas origens, costuma-se ser comum encontrar capoeiristas ligados ao Candomblé, tendo em vista as origens próximas destas duas manifestações culturais afro-brasileiras. Além disso, percebemos em muitas das músicas cantadas referências aos santos e orixás, demonstrando a preocupação com o sagrado. Vemos, portanto, que indiretamente, existe uma energia deífica presentificada nas dinâmicas das rodas de "capoeira", especialmente pela corporalidade, pelo ritual e pela musicalidade. Não se trata, portanto, de um deus em seu sentido stricto, mas de uma energia fisicalizada e tornada visível neste conjunto marcial e artístico. O "aikido" também não é considerado uma prática religiosa, entretanto, possui uma de suas bases fincadas na seita oriental omoto e tem a preocupação de se conectar com dimensões invisíveis por meio de práticas bem definidas envolvendo o corpo, o espaço, a relação com os parceiros e signos específicos. Na prática desta arte marcial, por exemplo, quando usamos a respiração para conectar nosso $k i$ com o $k i$ do universo, o "invisível" está sendo acessado por meio de todo o corpo. Percebe-se, portanto, que em ambas as artes, a conexão com o não concreto e com o invisível está presente em uma corporalidade específica de forma intensa. Busca-se, dessa forma, a conexão com as energias e com dimensões que não são palpáveis, mas que são percebidas sensorialmente e potencializadas em cada ação dos envolvidos. 
Enfim, a partir do exposto, percebemos que o ritual proporciona a encarnação de ideias durante sua praxis, tornando o pensamento uma ação. Tomando como referência o "aikido" e a "capoeira", identificamos que, durante suas dinâmicas, um "diálogo" entre os integrantes acontece, ainda que na maior parte do tempo essa comunicação se dê apenas corporalmente. Além disso, percebemos nos corpos, nos movimentos, nos códigos e nos símbolos utilizados, as histórias que fundamentaram estas práticas e a forma de interagir com o que está à volta. Vemos, por exemplo, no "aikido", um tipo de seriedade, de polidez e de disciplina, elementos característicos da cultura japonesa, que contrastam com a descontração e a atmosfera "festiva" da "capoeira", sem perder a seriedade e a dedicação dos participantes aos treinos. Complementando o exposto, Schechner, 2012, ainda expõe que, segundo os etólogos, todas as funções presentes em um ritual estão recobertas de crenças, ideologias e conhecimento, sendo, portanto, carregadas de sentidos. Nada do que se faz em um ritual tem uma função puramente mecânica. Assim, quando se inclina na direção do parceiro curvando a coluna para cumprimentá-lo ou quando se abaixa próximo ao berimbau antes de iniciar o jogo, se faz com um propósito muito específico e com uma crença clara: são ambas as formas distintas de se pedir autorização para começar e se preparar para esta nova etapa, criando a conexão entre o(s) parceiro(s) e com o entorno. Assim como estes movimentos tem seus significados, todos os outros que compõem uma roda de "capoeira" ou um treino de "aikido" em um dojo são carregados de informações e de sentidos. E cada um desses elementos ritualísticos nos afetam de maneiras diferentes, tendo em vista que nos movem sensorialmente de forma completa por caminhos diversos.

Todos os elementos aqui apresentados serviram para fundamentar a elaboração de procedimentos de trabalho com os atores de forma que se sentissem afetados de diferentes maneiras. Neste ponto é importante relembrar o conceito de corporeidade exposto inicialmente. A corporeidade está ligada ao fenômeno corporal de se conectar com o mundo à volta por dimensões diversas: fisiológica, intelectual, cultural, social, lúdica, etc. Este processo complexo de conexão entre corpo e mundo pode auxiliar muito o trabalho do ator se é posto a sua disposição elementos que o acessem por diferentes caminhos. Portanto, nesta pesquisa, um vasto repertório de elementos culturais foi construído a partir da análise do processo ritualístico presente no "aikido" e na "capoeira" de modo que o ator se sentisse munido de mais material para criar e mais preparado psicofisicamente. 
É importante ressaltar que este processo de criação procurou seguir de forma que as duas artes marciais auxiliassem conjuntamente a composição da dramaturgia e que não atuassem de forma separada e independente. $\mathrm{O}$ trabalho corporal e o estudo sobre as duas foram afetando o desenvolvimento do processo criativo durante todo o tempo. Assim, pelos caminhos do corpo fomos buscando as intersecções entre estas artes marciais de origens culturais distantes procurando fazer com que elas não se anulassem, mas que, ao contrário, chegassem a um equilíbrio onde em alguns momentos a mescla entre as duas acontecesse e em outros que as tensões entre elas ajudassem a poetizar os conflitos presentes na peça. Podemos dizer, portanto, que esta pesquisa provocou uma hibridização cultural ao trazer para uma mesma prática artes marciais de contextos diferentes visando à concepção de uma única obra artística. Acerca desse processo, convém tecer alguns comentários sobre hibridização.

Cultura híbrida pode ser definida como a miscigenação de culturas diversas cuja heterogeneidade rompe barreiras entre o tradicional e o moderno criando uma nova cultura e novas formas de ver o mundo. $\mathrm{O}$ termo hibridização cultural foi proposto por Nelson Canclini para definir

Processos sócio-culturais nos quais estruturas ou práticas discretas, que existiam de forma separada, se combinam para gerar novas estruturas, objetos e práticas. Por sua vez, cabe esclarecer que as estruturas chamadas discretas, foram resultado de hibridizações, portanto não podem ser consideradas fontes puras. (CANCLINI, p. 14, 2001)

Canclini, 2001, propõe, portanto, que toda sociedade passa por mesclas de culturas e que, mesmo as que não são tidas como híbridas, passaram por este mesmo processo. É, portanto um fenômeno universal, de evolução natural, as quais todas as sociedades estão sujeitas. Às vezes acontece de forma planejada, às vezes mais imprevista como nos processos migratórios, mas com frequência surgem da criatividade individual e coletiva em diversas áreas como na vida cotidiana, na arte e no desenvolvimento tecnológico. A América Latina, segundo este autor, seria o lugar em que esta hibridização é mais notada em virtude do processo de colonização.

No Brasil esta cisão de culturas deu origem a diversas formas artísticas e religiosas de expressão como o candomblé e a umbanda, resultados do sincretismo religioso, o Tambor de Crioula e o Maculelê, danças populares afro-brasileiras, o carnaval, fruto da mescla de diversas culturas que formaram o povo brasileiro e a 
própria língua portuguesa brasileira que teve seus sotaques e palavras definidos pelos diferentes povos que estabeleceram raízes no país.

Canclini, 2001, defende ainda que não funciona a oposição abrupta entre o culto e o popular, o tradicional e o moderno, e que é necessário desconstruir esta divisão e averiguar sua hibridização ou, como acha também apropriado chamar, sua mestiçagem. Prega para tanto, a necessidade de uma ciência social nômade, que circule por estas áreas e as comunique.

Tendo em vista esta noção de hibridização, ao pensarmos na utilização dos elementos da "capoeira" e do "aikido" nesta pesquisa procuramos abrir para novas possibilidades, em que o pensamento binário que povoa muitas sociedades como preto/branco e oriente/ocidente, não existisse. As diferenças e os paradoxos estão presentes em qualquer cultura e foram aqui tratadas como elementos que se complementam, e não como ideias que se opõem e se excluem. Fomos aos poucos, durante o treinamento e o processo de criação, eliminando a ideias de fronteiras e de limites para nos abrirmos para a multiplicidade de material que as duas artes marciais aqui estudadas poderiam proporcionar, de modo que um terceiro estado e uma outra identidade fossem sendo construídos. Trata-se, portanto, de uma contaminação, em que a troca de informações proveniente de duas culturas diferentes gera um processo único. Assim, ao pensar em uma encenação que objetivasse a criação por meio do "aikido" e da "capoeira", pensou-se em criar um diálogo entre as duas artes de modo que conjuntamente contassem uma história, evitando assim, transformar o trabalho em uma "colcha de retalhos" com partes desconexas. Este esforço pode ser visto tanto na conexão entre as cenas compondo uma única narrativa, quanto na caracterização dos personagens que foram embasados em ambas as artes. A cerca disso, podemos perceber essa hibridização no figurino proposto por Thaís Dias que, em diálogo com os envolvidos e com as cenas criadas, propôs vestimentas que tivessem tanto elementos afro-brasileiro como japonês de modo a ressaltar a característica de cada personagem. 
Imagens de 102 a 107: figurinos.

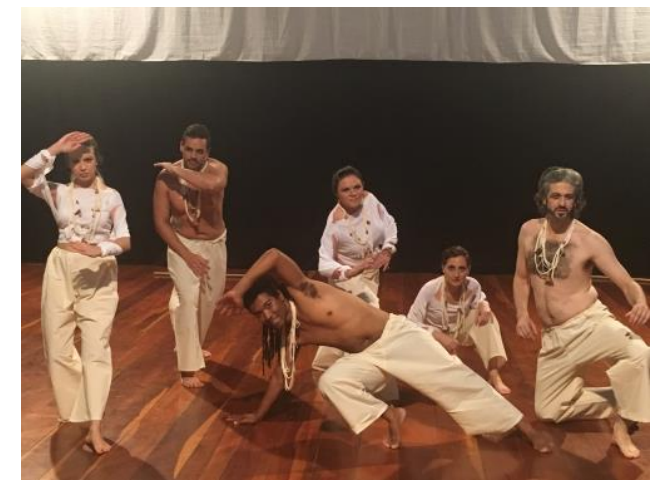

Figurino base

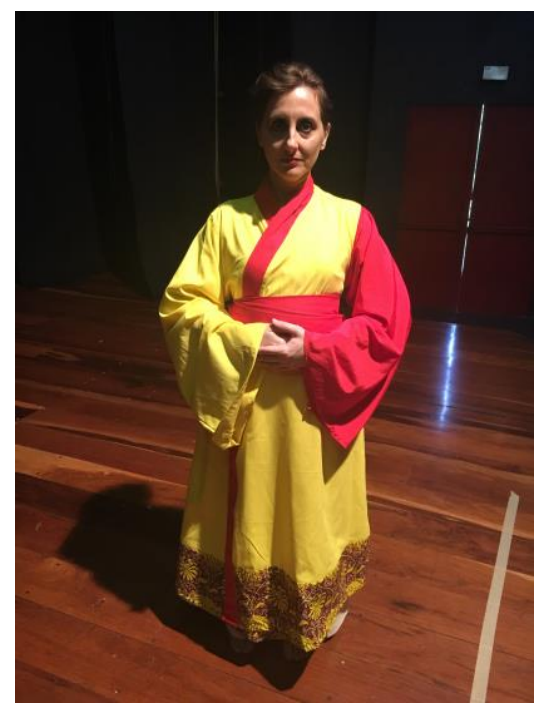

Ofélia

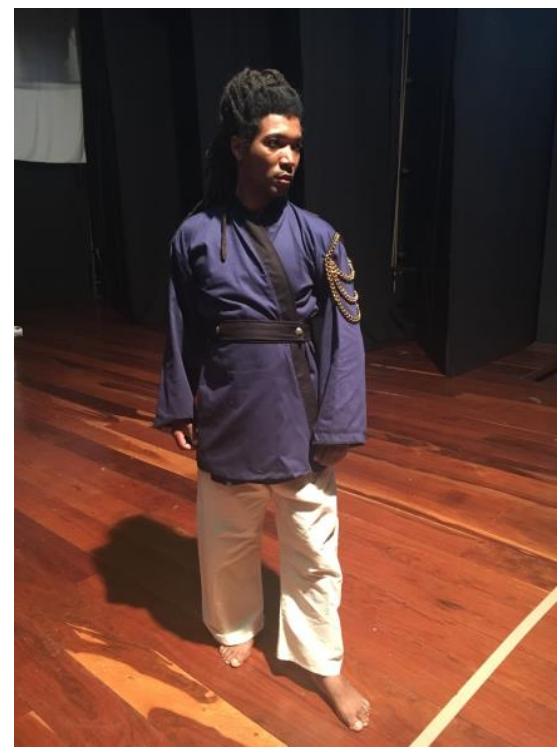

Hamlet

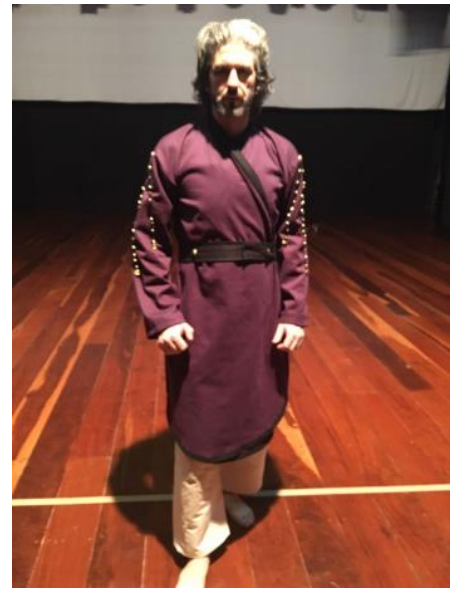

Rei Cláudio

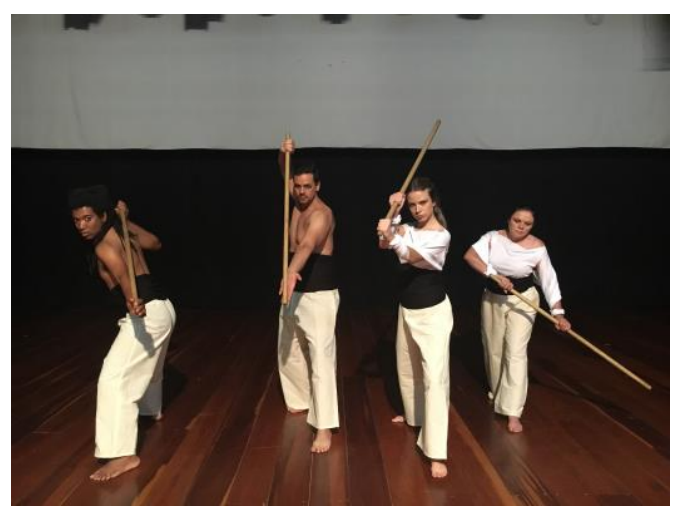

Laertes

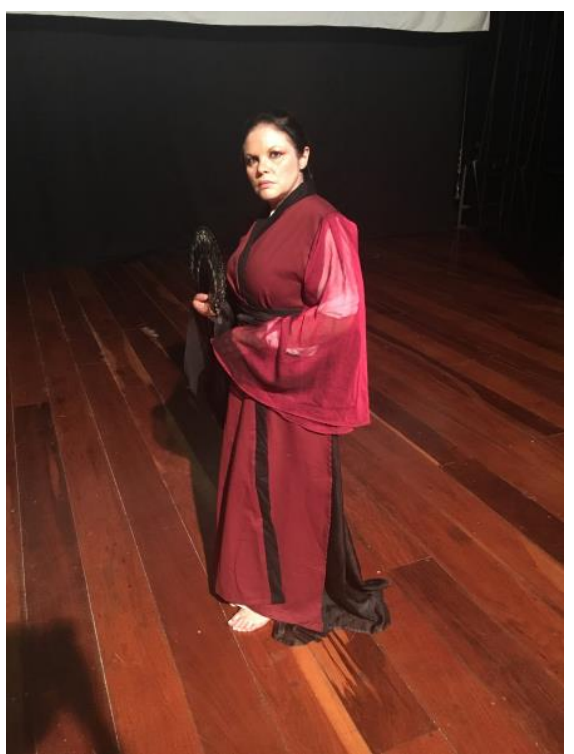

Gertrudes 
A fim de deixar claro de que forma se deu a conexão entre a ritualidade do "aikido" e da "capoeira", o trabalho do ator e a construção da dramaturgia, apresentaremos alguns exemplos práticos a seguir.

A inclusão dos aspectos ritualísticos da cultura afro-brasileira e japonesa no processo prático se deu com o último núcleo formado, com quem utilizamos o texto Hamlet. As conexões estabelecidas entre a peça de Shakespeare e os elementos históricos e culturais das artes aqui estudadas se deram por diferentes caminhos, desde mais racionais como estudos sobre o contexto social que envolveu o "aikido" e a "capoeira", até mais orgânicos no sentido de ter o corpo como um todo participando desse processo e ajudando a definir os encaminhamentos práticos. Estas diferentes formas de abordar a ritualidade foram se entrelaçando, conforme o treinamento foi avançando.

Inicialmente, em virtude de a "capoeira" ter, em suas origens, um histórico popular, tendo ficado por muitos anos à margem da sociedade e o "aikido" ter sua origem mais próxima da nobreza, dada sua conexão remota com os samurais, decidimos inicialmente que os personagens nobres como Rei Claudio e a Rainha Gertrudes seriam construídos basicamente a partir da arte marcial japonesa. Por conseguinte, personagens de origem mais simples como os criados e os atores teriam como base de inspiração a "capoeira". Esta foi apenas uma abordagem inicial para experimentarmos alguns elementos do contexto histórico. Ao nos aprofundarmos na dramaturgia e no contexto das artes em questão, começamos a estabelecer outras conexões que trouxeram para o processo outras variáveis, como é o caso do rei morto. Para a abordagem deste personagem um aspecto que nos chamou a atenção foi o fato de ter sido assassinado por Cláudio traiçoeiramente enquanto dormia. Estávamos, portanto, diante de uma figura importante, de poder, que foi traído e assassinado. A respeito disso, identificamos um ponto de contato com uma figura importante da "capoeira": o Besouro Mangangá ou Besouro Cordão de Ouro, um dos capoeiristas baianos mais respeitados e admirados. Sua vida inspirou muitas histórias e cantigas, tendo se tornado, por seus feitos, um mito no universo da "capoeira". Recebeu esse nome, pois se dizia que, quando percebia que não ia conseguir vencer uma luta, se transformava em besouro e saía voando. Sua morte, ainda contraditória, inspirou também muitas letras de músicas, sendo a mais conhecida a de que tenha sido morto traiçoeiramente com uma facada nas costas. Assim, a figura de um homem respeitado, com certo poder sobre os que o cercavam e a morte por traição, se entrelaçou à figura do pai de Hamlet. Além disso, estabelecemos 
um paralelo entre o fantasma, ancestral do príncipe Hamlet, que retorna ao mundo dos vivos e a ideia da ancestralidade presente na "capoeira" com a reafirmação do mito Besouro Mangangá. Temos em ambos os casos, a partir da relação entre o fantasma e esta figura mitológica da "capoeira", uma concentração de energia a fim de dar vida à memória. Como no início do processo esta cena já havia sido experimentada na "roda de improviso" a partir dos princípios da "capoeira", decidimos seguir nesse caminho e concebemos a cena tendo como referência a ideia da instauração de um ritual com a ajuda do berimbau e do agogô com o momento da chegada do fantasma.

Imagens 108 e 109: processo criativo.
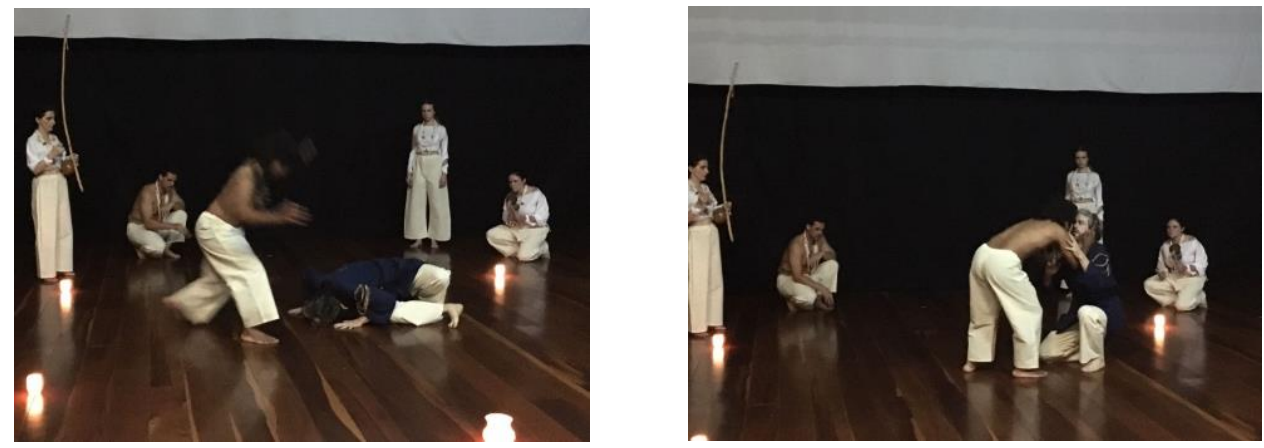

Fontes: arquivo do autor.

O Rei assassinado nos inspirou a criação de outra cena que não está presente no texto de Shakespeare, mas que consideramos importante integrá-la à dramaturgia: o funeral do rei morto, que em nossa encenação antecedeu o encontro do fantasma com Hamlet. Quando vivo, Hamlet Pai era Rei, portanto, fazia parte da nobreza. Por esta razão, resolvemos retomar a ideia inicial de conectar os elementos do "aikido" à nobreza e concebemos cenicamente o funeral do Rei. Nesta cena, toda a movimentação dos pés teve como referência o tenkan e o irimitenkan na base do kamae e o deslizamento dos pés no chão, suriashi. Para a respiração e a sonoridade nos baseamos no kototama a fim de reforçar a atmosfera cerimoniosa e trazer elementos sensoriais para a cena que afetassem o público de uma forma diversa da que viria na sequência com o berimbau. Já as movimentações, a disposição dos atores pelo palco, os objetos usados como velas e a relação com o morto foram inspiradas no culto tradicional budista japonês.

Segue abaixo algumas imagens da cena. No DVD anexo pode-se assistir esta cena. 
Imagens 110 e111: cena Funeral do Rei.
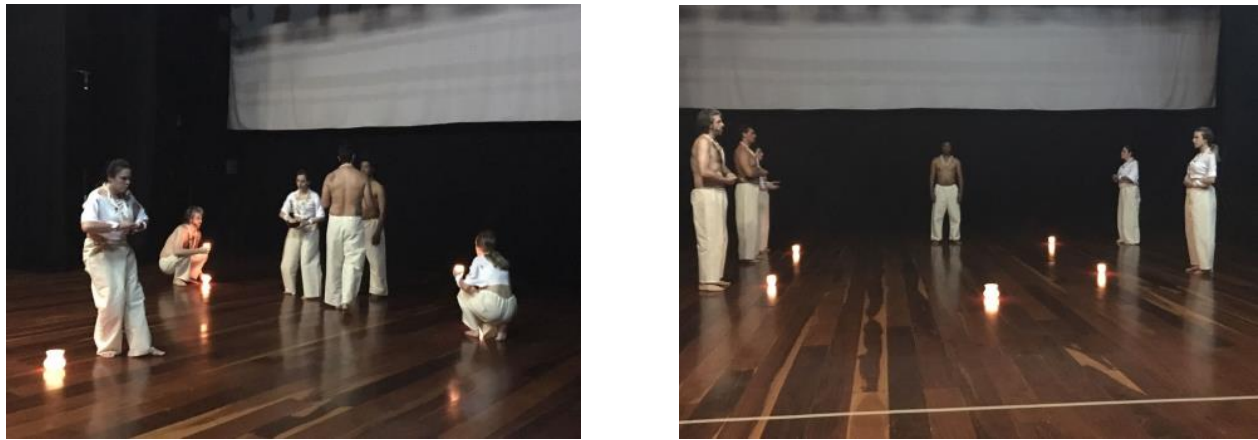

Fontes: arquivo do autor.

Ao pensar na conexão entre essas duas cenas para a encenação - funeral e visita do fantasma - resolvemos fazer uma passagem suave de uma para a outra e mantendo elementos presentes na cena do funeral, na cena seguinte quando o fantasma vem conversar com o filho, a fim de ajudar na ambientação da cena e evitar uma quebra brusca de um momento para outro.

Outro exemplo de processo que deixa claro os caminhos que percorremos a respeito da conexão entre os princípios selecionados e os elementos culturais do "aikido" foi o da personagem Ofélia. Ofélia foi concebida quase que inteiramente por elementos presentes na ritualidade da cultura japonesa. Este ponto de contato se deu a partir de diversas experimentações corporais aliadas ao estudo teórico. Duas cenas que podem ilustrar esse processo são as que se referem à loucura e à morte de Ofélia. Como anteparo para estes momentos, utilizamos a figura da geisha ${ }^{44}$, cujas conexões seguem abaixo descritas:

1. A feminilidade como forte característica de ambas. Ao observar uma gueixa se arrumando para realizar suas atividades, percebe-se o cuidado e o detalhamento desta preparação que envolve maquiagem, vestimenta, perfume, penteado e adereços. Já Ofélia, tanto pelo texto de Shakespeare como por suas inúmeras representações pictóricas, é caracterizada por diversos elementos do

\footnotetext{
${ }^{44}$ Gueixa (gueisha) é uma palavra japonesa utilizada para designar as mulheres com formação artística na cultura tradicional japonesa em várias áreas, especialmente em canto, dança, instrumento, postura e etiqueta, com o fim de entreter clientes em banquetes, festas particulares ou outros eventos onde forem requisitadas. São caracterizadas por vestimenta, penteado e maquiagem extremamente detalhados e cuidadosos. Em início de formação a candidata à gueixa é chamada de maiko que quer dizer aprendiz.
} 
universo feminino como flores, maquiagem e movimentos leves como indica o trecho a seguir:

"Já ouvi falar também, e muito, de como você se pinta. Deus te deu uma cara e você faz outra. E você ondula, você meneia. (...)"

2. A submissão ao sexo masculino. Mais modernamente essa questão não é mais tão fortemente percebida, mas ao longo da história japonesa, as mulheres ocuparam uma posição de submissão em relação aos homens, as tornando obedientes e dependentes deles. As gueixas seguiam este pensamento e deviam servir os homens os entretendo com seus dotes artísticos. Entretanto, esta submissão trazia embutido o poder da sedução. Com suas habilidades as gueixas tinham um forte poder de sedução e, na medida em que ofereciam aos homens o que eles esperavam, se colocavam, de certa forma, em controle da situação. Ao olharmos para Ofélia encontramos uma personagem cercada por homens - seu irmão Laerte, seu pai Polônio e Hamlet - que empenham esforços em controlar sua vida por meio de conselhos, sugestões, orientações e instruções. Em relação a Hamlet ela o conquista por um tempo, chegando a ter uma aproximação amorosa, mas é desprezada por ele, quando este resolve finalmente colocar seu plano em prática para vingar a morte de seu pai. Shakespeare neste texto propõe que os papéis sociais exercidos por homens e por mulheres são definidos pelos padrões sociais e culturais que os envolvem, assim como ocorria no contexto cultural japonês. Abaixo seguem alguns trechos que demonstram esse entendimento:

I. LAERTES: Quanto a Hamlet e ao encantamento de suas atenções, aceita isso como uma fantasia, capricho de um temperamento, uma violeta precoce no início da primavera; suave, mas efêmera, Perfume e passatempo de um minuto -Não mais. OFÉLIA: Não mais que isso?

LAERTES: Não mais;

II. POLÔNIO: O que há entre vocês? Quero a verdade. OFÉLIA: Senhor, ultimamente ele tem me dado muitas demonstrações de ternura. 
POLÔNIO: Ternura! Qual! Você fala como uma moça ingênua. Inconsciente do perigo em que se encontra. Você acredita nessas ternuras de que fala?

OFÉLIA: Senhor, não sei o que pensar.

POLÔNIO: Por Deus; você está agindo como uma menina

Que ganha uma moeda falsa e acha que é dinheiro de verdade."

III. HAMLET: $O$ poder da beleza transforma a honestidade em meretriz mais depressa do que a força da honestidade faz a beleza se assemelhar a ela. Antigamente isso era um paradoxo, mas no tempo atual se fez verdade. Eu te amei, um dia."

3. A aproximação às artes. Ofélia canta quando está alucinando e se aproximando da morte. O canto e a dança fazem parte das funções da gueixa e, portanto, dedicam muito tempo a isso. Aproveitamos dessa forma, seu canto, sua dança, seu estilo de movimentação e sua postura para construir a caracterização de Ofélia nestas cenas. O canto nestas duas cenas serviu apenas como inspiração e não houve a preocupação de copiá-lo, tal como consta no original. Aproveitamos a sonoridade e a melodia destas canções e as mesclamos com trechos do texto de Shakespeare. Os princípios do "aikido" foram fundamentais nesta etapa para inspirar a criação dos deslocamentos da personagem pelo espaço, bem como seus movimentos. Neste caso, seguindo a estética da dança das gueixas, lançamos mão da base kamae, do tenkan, do irimitenkan e das mudanças de peso, para proporcionar a estabilidade ao caminhar, bem como das torções dos membros superiores, desenhando com os braços e mãos linhas sinuosas, sensuais, precisas e expressivas pelo espaço.

Segue abaixo a transcrição da cena quando Ofélia aparece aparentando certa loucura, da forma como ficou em nossa dramaturgia:

(entra Ofélia cantando, canto este inspirado no canto da gueixa.)

OFÉLIA: Onde se encontra a bela Majestade da Dinamarca?

A RAINHA: Que há, Ofélia? 
OFÉLIA: (canto inspirado na gueixa)- Como reconhecer em meio à turba o jovem meu amado? Pelo chapéu de conchas, as sandálias, e mais pelo cajado.

A RAINHA: o que houve?

OFÉLIA: Que dizeis? Ele se foi; não mais existe; morreu; (canto inspirado na gueixa.) Como um monte de neve era a mortalha. Enfeitada de flor; orvalhada baixou para o sepulcro, pelo pranto do amor.

O REI: Como vai passando, Ofélia?

OFÉLIA: Bem, graças a Deus. Dizem que a coruja era filha de um padeiro. Sabemos, senhor, o que somos, mas não o que viremos a ser. Deus assista na vossa mesa.

O REI: Alusão ao pai. (canto de Ofélia inspirado na gueixa)

OFÉLIA: Por favor, não falemos mais disso; mas se vos perguntarem o que significa, dizei-lhes:

(Canto inspirado na gueixa) Raiou o dia de São Valentim; de pé todos estão. Para ser vossa Valentina, irei pôr-me à janela, então. Ela se alça depressa, a roupa veste e a porta lhe franqueou, fazendo entrar a virgem, que, assim, virgem, não mais ali passou. (canto inspirado na gueixa) OFÉLIA: Espero que tudo corra bem. Precisamos de paciência, conquanto não possa deixar de chorar, ao pensamento de que vão depô-lo no chão frio.

O REI: Há quanto tempo está ela assim?

Ofélia: Boa noite, senhores! Boa noite! Boa noite!

Imagens 112 e 113: cena Enouquecer de Ofélia.
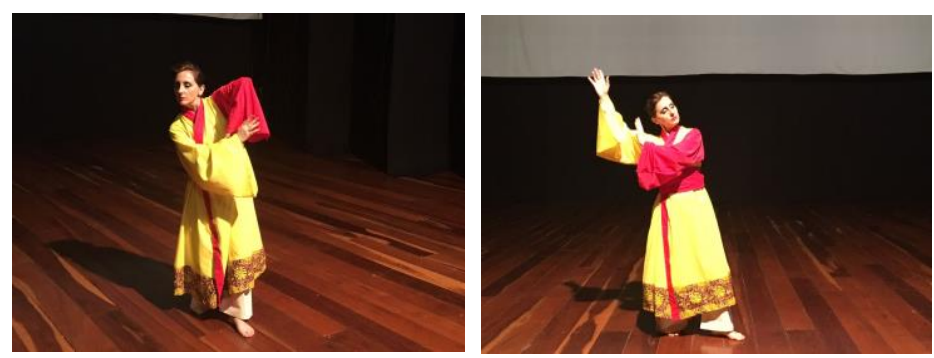

Fontes: arquivo do autor. 
4. Ritual de suicídio para proteger a honra. A cena da morte de Ofélia foi concebida como se fosse um ritual de morte inspirado no seppuku, versão feminina do ritual do suicídio, normalmente praticado em épocas de guerra, quando as mulheres estavam na eminência de serem desonradas, como em casos de violência sexual. Utilizavam uma adaga, que deveria cortar o ventre ou a aorta, e se posicionavam em seiza com os joelhos amarrados para que o corpo se mantivesse firme e não tombasse após a morte. A morte de Ofélia no rio, portanto, foi concebida a partir do entrelaçamento com os elementos do seppuku. A água, que é um elemento importante para esta cena no texto de Shakespeare, foi mantida, mas sua presença foi ajustada às necessidades deste ritual. Esta cena pode ser assistida no DVD que segue anexado.

Imagens 114 e 115: cena A morte de Ofélia.
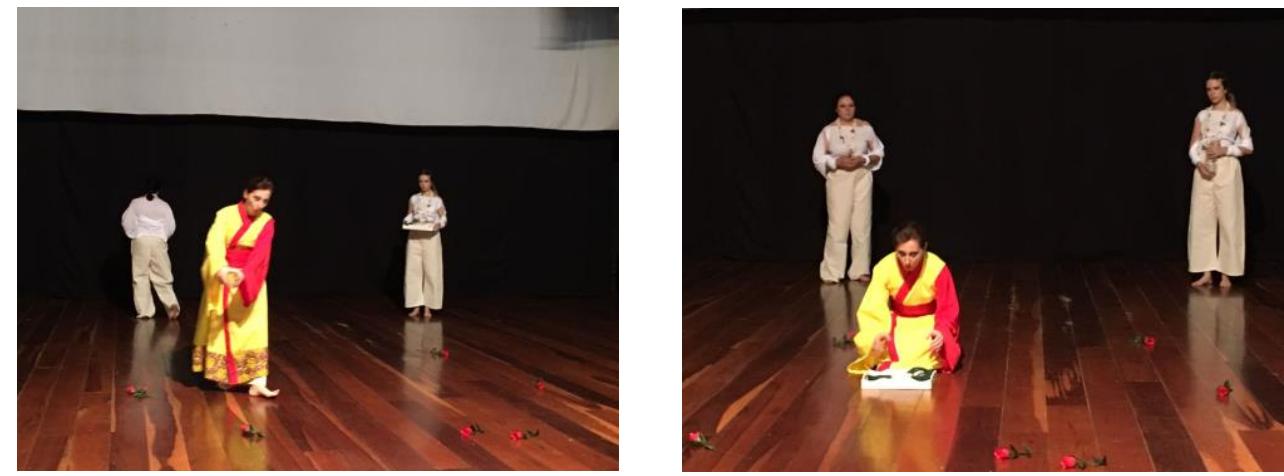

Fontes: arquivo do autor.

Outro exemplo que deixa clara a conexão dos aspectos ritualísticos de ambas as artes com a criação da dramaturgia é a cena em que o Rei Cláudio e Laertes, juntos, voltam-se contra Hamlet, envenenando a taça e a lâmina da espada. Elaboramos esta cena de modo que elas se interseccionassem, pontuando a cumplicidade entre os dois personagens. Ambas as ações foram realizadas como se fosse parte de um ritual, que foi concebido tendo como referência os elementos que estávamos pesquisando. Também seguindo o repertório selecionado, a espada foi substituída por um bastão semelhante ao $j o$, para que pudessem ser aproveitadas as habilidades que os atores estavam aprofundando desde o início do treinamento. Dessa forma, na cena em que Laertes envenena a espada, em nosso caso amaldiçoa o bastão, recorremos a algumas técnicas praticadas com jo. A ideia era a de que as circunstâncias presentes na peça, bem como o texto dito por este personagem, fossem corporalizados pelo movimento e pela relação com o bastão. Neste caso, portanto, as técnicas com jo experimentadas durante o treinamento focando a preparação, serviram como material criativo para os atores. Esta mudança na forma de se relacionar e de usar o que foi aprendido deveu-se ao fato de 
que os atores passaram por um período de prática em que eles puderam se apropriar dessas novas informações e se ajustar a um repertório que não estavam acostumados. Ao se sentirem mais confiantes, eles puderam ir, aos poucos, trazendo qualidades pessoais para as técnicas. Esta pessoalidade na realização dos movimentos permitiu que os atores transformassem uma técnica em uma ação física significativa. Temos, portanto, que as etapas de criação por meio da imitação apontadas por Zeami foram utilizadas aqui, na medida em que houve primeiramente o primeiro contato com esse repertório, em seguida deu-se uma identificação com a apropriação pessoal do que foi aprendido e, por fim, aconteceu a transformação criativa desse material. Dessa forma, as técnicas com bastão realizadas pelos atores, passaram a ser uma recriação, uma vez que, os movimentos técnicos codificados por outra pessoa passaram a ser parte deles próprios. Em relação ao ritual do Rei com a taça envenenada, decidimos experimentar a mescla dos elementos da "capoeira" e de "aikido" a fim de descobrir o que poderia advir dessa experiência.

Consequentemente, a cena de envenenamento da taça foi concebida a partir dos seguintes princípios: respiração em conexão com o movimento tendo o hara como centro "aikido", uso do kiai "aikido", esquivas em nível baixo "capoeira", equivalência da técnica de jo com a taça, "aikido", sinuosidade "capoeira". Diante da intersecção entre os dois rituais, resolvemos incluir um elemento da "capoeira" no ritual de Laertes que foi o som de percussão, a fim de conseguir um aumento de tensão da cena, respeitando o princípio japonês jo ha kyu de progressão rítmica. Assim, o jo estaria no começo da cena do Laertes, o ha na entrada do Rei Cláudio e o kyu no momento do kiai crescente do rei com a percussão do Laertes. Por fim, convém acrescentar que nesta cena tomamos a liberdade de conceber o personagem Laertes em coro, ou seja, com vários atores realizando os mesmos movimentos e dizendo o texto ao mesmo tempo.

Imagem116: coro de Laertes.

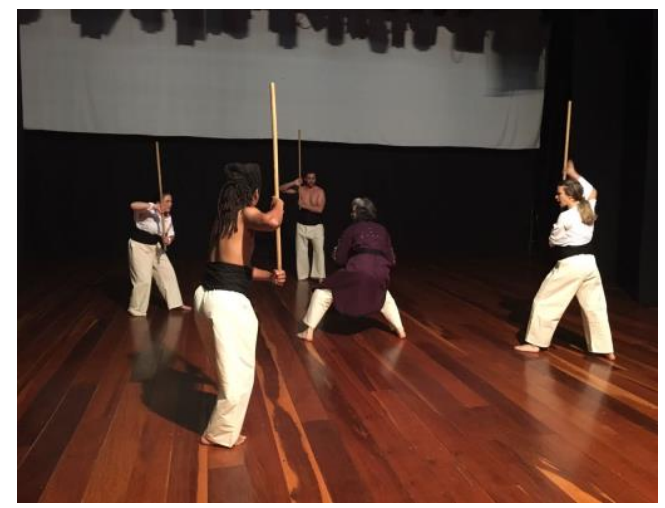

Fonte: arquivodo autor. 
A ideia de coro foi utilizada em outras cenas tanto com Laertes como com Hamlet por entendermos que a movimentação em coro traz uma intensidade diferente da movimentação de um único ator. Por essa razão optamos por introduzir o personagem Laertes como coro em cena anterior ao ritual onde ele surge raivoso questionando Rei Cláudio sobre o paradeiro de seu pai, Polônio. Neste caso procuramos fisicalizar a diferença de forças desdobrando Laertes em vários atores, em oposição a figura do Rei que foi representado por um único ator. Nesta cena, recorremos também às técnicas de jo para criar esse conflito entre os dois personagens, conforme se observa nas imagens abaixo. Estas cenas podem ser assistidas no DVD anexado.

Imagens 117 a 119: Laerte confronta o Rei Claudio sobre o paradeiro do pai.
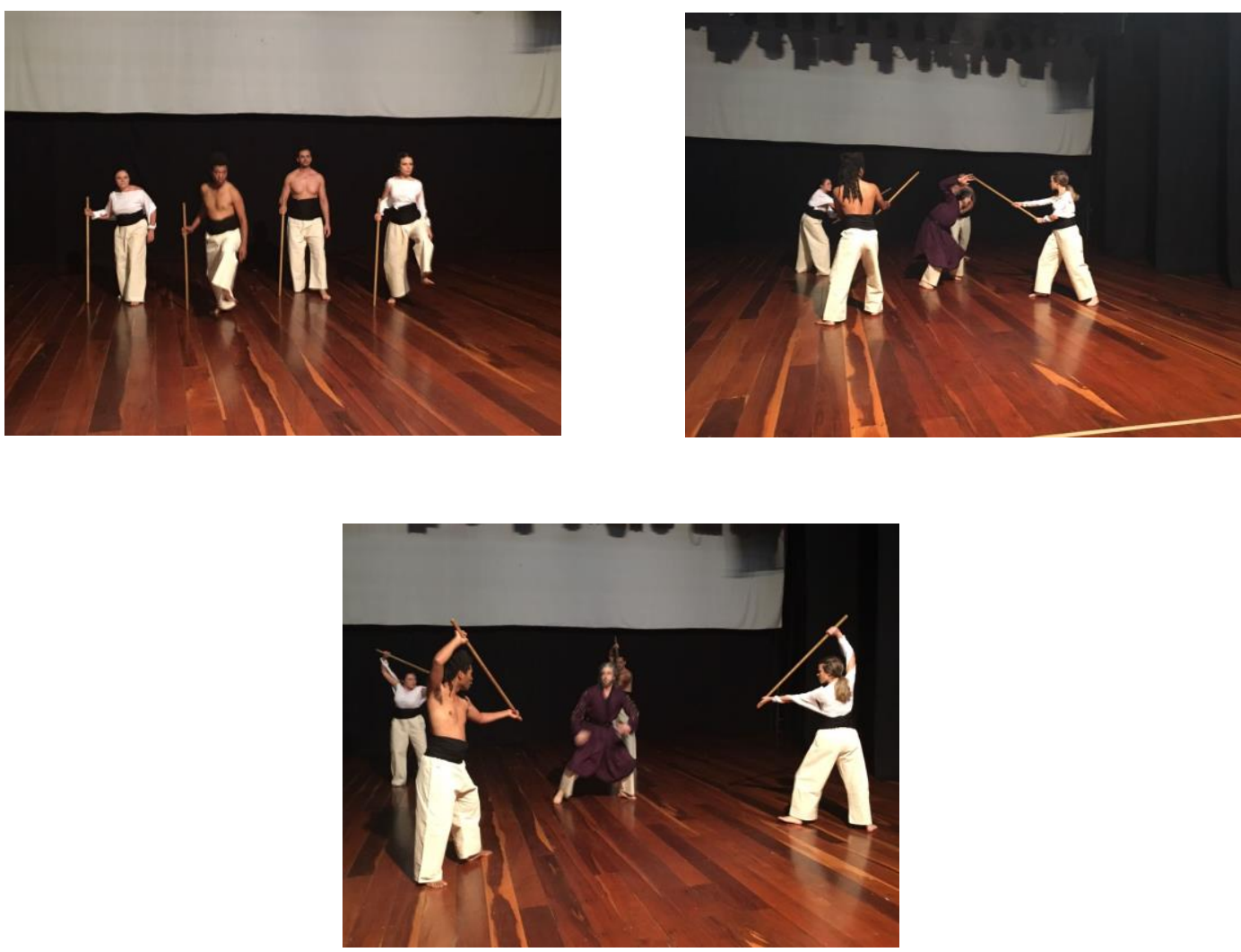

Fontes: arquivo do autor. 
Imangens 120 a 123: Ritual de envenenamento da taça e do bastão.
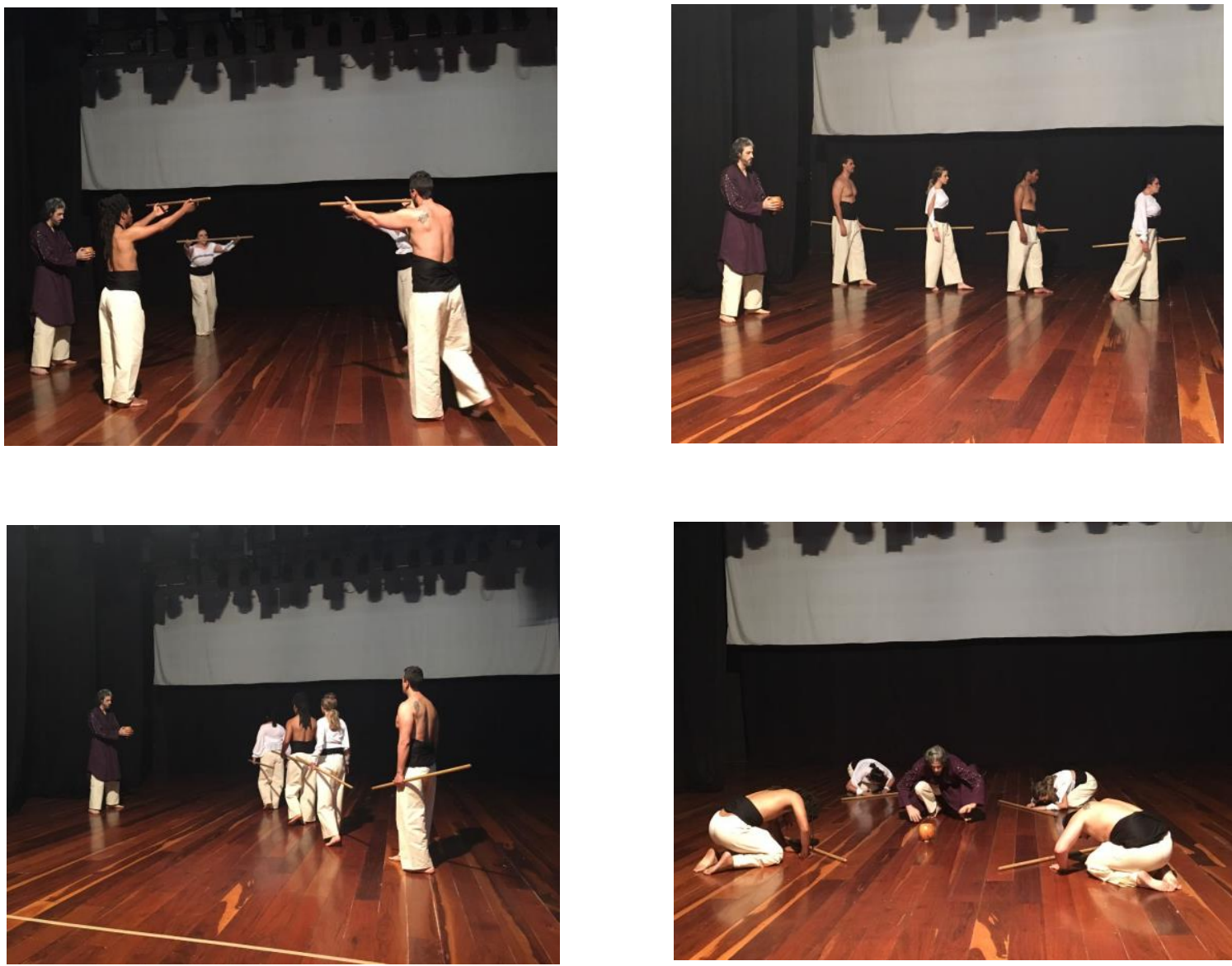

Fontes: arquivo do autor.

Percebe-se, portanto, por todo o exposto, que em todo o processo de criação, os estudos sobre os elementos ritualísticos presentes nestas artes marciais serviram de inspiração para a composição da dramaturgia que estava surgindo na prática. Além disso, a respeito do trabalho do ator, os elementos lúdicos aqui citados caminharam lado a lado com os ritualísticos de modo que um fosse afetando o outro. Assim, quando improvisávamos a partir da pesquisa sobre um ritual, elementos do jogo também estavam presentes para auxiliar neste processo de criação e vice-versa. Por fim, procuramos fazer com que tudo o que foi experimentado no treinamento permeasse o processo, afetando esteticamente o trabalho dos atores e a encenação como um todo. 


\section{Considerações finais}

Concebemos este trabalho a partir da ideia de que o corpo possibilita a criação de uma gama infinita de manifestações artísticas, das obras mais realistas às mais abstratas. Desta forma, durante o desenvolvimento da prática procuramos aprofundar a compreensão sobre um fazer teatral que tivesse como foco o corpo humano e seus movimentos psicofísicos. Nesta pesquisa, que teve sua semente no mestrado, tanto o "aikido" como a "capoeira" nos auxiliaram no processo, desvendando muitos elementos turvos e até desconhecidos em alguns momentos. Nesta trajetória desenhada a partir das artes marciais aqui estudadas para o aprimoramento do trabalho do ator, pude aprimorar tanto o meu trabalho de atriz quanto de diretora e auxiliar na formação de outros atores que também estavam desejosos de compreender melhor as potencialidades do corpo, seus aspectos relacionais e de criação. Além disso, estas duas artes proporcionaram o contato com um contexto cultural novo para todos os envolvidos nesta investigação.

Podemos dizer também que a aproximação destas artes marciais como recurso para a elaboração de um treinamento do ator, ampliou nossa compreensão sobre o ser humano, nos ajudando a perceber que cada ser vivo é composto de uma infinidade de relações e de afetações que o torna único. Somos, portanto, muito mais do que nossos sentidos podem perceber de imediato. Este olhar diferenciado para o ser humano como um todo, por conseguinte, influenciou a maneira de lidar com a criação artística que, para esta pesquisa, entendemos que esteja conectada às formas como o ser vivo e o contexto em que se insere, são vistos, percebidos e entendidos. Assim, uma compreensão mais aprofundada do corpo por meio das artes marciais citadas, fez dos envolvidos nesse processo artistas mais férteis e com uma percepção mais apurada.

Pensando especificamente no trabalho prático, o fato de estar trabalhando com atores que em sua maioria eram recém-formados em curso profissionalizante e sem grande experiência em teatro, pareceu-me inicialmente um problema, já que meu objetivo primeiro ao pensar nesta pesquisa foi o de focar na criação de um espetáculo. Entretanto, conforme a pesquisa avançava, percebi uma nova possibilidade se abrindo, a de deixar de almejar apenas um resultado espetacular para começar a me concentrar na formação do ator de modo que o período de preparação estivesse conectado ao processo de criação, resultando assim em uma obra cênica, seja um espetáculo inteiro ou apenas algumas cenas, que refletisse o grau de envolvimento e de trabalho de cada ator. Diante do que estava sendo apresentado pelo grupo de atores participantes na prática, houve, 
portanto, um redirecionamento do meu olhar de pesquisadora que tornou essa investigação mais completa e com maior aprofundamento. $\mathrm{O}$ fato de começar a pesquisa lidando com atores que ainda não estavam prontos para transformar os elementos extraídos do "aikido" e da "capoeira" em material cênico, fez com que eu desse um passo atrás em meu planejamento e pensasse, com maior cuidado, quais poderiam ser os melhores caminhos a serem tomados para abordar estas artes marciais como recursos para a cena. Foram então sendo construídas etapas mais detalhadas e melhor fundamentadas, de modo que os atores se sentissem mais apoiados ao utilizar os elementos novos que lhes eram apresentados para a criação cênica.

Neste processo de evolução gradual, de acordo com o avanço dos envolvidos, começou a ficar mais claro para mim o objeto que estava pesquisando e pude desvendar novas camadas e diferentes nuances no trabalho que estava desenvolvendo. Dessa forma, o que era visto inicialmente como uma dificuldade, se transformou durante o processo em um importante material de trabalho.

Conforme procuramos expor ao longo desta tese, nesta pesquisa partimos das técnicas, da história e da filosofia do "aikido" e da "capoeira" para criar procedimentos que preparassem o ator para a cena e que fornecessem elementos estimulantes para a criação dramatúrgica. Em outras palavras, objetivou-se, construir um processo que auxiliasse o ator na transposição do corpo cotidiano para um corpo cênico tendo como referência os elementos extraídos das artes marciais referidas. Nesta trajetória os elementos técnicos selecionados serviram como impulso para a potencialização das qualidades de cada ator e para a superação de seus limites. Todo o material apresentado aos atores dialogou todo o tempo com as necessidades, características e desejos de cada um, respeitando-se, assim, as individualidades. Seguindo este caminho, dentre outras coisas, objetivou-se ampliar o repertório, trabalhar a autoconscientização corporal, aprimorar a flexibilidade física, desenvolver a concentração e o estado de prontidão, potencializar a capacidade de interação e de improvisação, melhorar a resistência física, estimular a imaginação e impulsionar a criatividade e a expressividade corporal.

Por conseguinte, toda a dramaturgia construída durante a prática foi alicerçada no que os atores foram conquistando e descobrindo durante as experimentações. Dessa forma, durante a prática, a etapa de preparação não se encerrou em si mesma e nem teve uma característica exclusivamente tecnicista, mas se completou e se conectou diretamente com o processo de criação, de modo que fosse construída uma trajetória que oferecesse degraus para que o ator pudesse pisar e se apoiar confiantemente por 
todo o trabalho. Desse modo, as fases de treinamento e de criação não foram realizadas separadamente, mas concomitantemente, seguindo as necessidades dos atores de acordo com a evolução da pesquisa.

Todo este percurso, entretanto, não foi construído apenas por certezas e afirmações, mas, ao contrário, por questionamentos, dúvidas e crises que foram sendo respondidos, aclarados e elucidados ao longo de todo o encaminhamento da prática. Assim, os erros e as tensões, em vez de travar as experimentações, funcionaram como estímulos para que descobríssemos novas possibilidades e novas formas de se abordar as artes marciais aqui estudadas. Convém esclarecer que estas elucidações não se deram apenas no ensaio com o grupo de atores que acompanharam mais diretamente esta pesquisa na prática, mas também em todas as oportunidades que tive para abordar e expor o tema, como em sala de aula com meus alunos do curso profissionalizante do Teatro Escola Macunaíma, em oficinas como a que aconteceu na Universidade da Costa Rica, em conversas com meus professores de "aikido" e de "capoeira" e em eventos acadêmicos e não acadêmicos que participei como Congressos, entrevistas e aberturas de processo em mostras de teatro, em que tive a oportunidade de interagir com mestres e praticantes destas artes e com o público em geral. Estas interações me fizeram perceber lacunas que precisavam ser preenchidas e questões que precisavam ser respondidas. Destas interações e conversas sobre a investigação prática, não é possível esquecer o Cepeca (Centro de Pesquisa em Experimentação Cênica do Ator), grupo para o qual apresentávamos regularmente o que estava sendo realizado, que com suas devolutivas nos auxiliou nessa trajetória, tornando menos árduo e solitário este caminho de descobertas e incertezas.

A fim de que todo o processo acima ficasse claro, tanto para nós atorespesquisadores que estávamos envolvidos, como para aqueles que viessem a entrar em contato posteriormente com esta pesquisa por meio desta tese, organizamos o texto de modo que os principais termos utilizados fossem devidamente explicados logo de início visando um melhor entendimento deste trabalho tais como corpo, corporeidade, corporalidade e dramaturgia. Nos dois capítulos seguintes nos preocupamos em apresentar de forma sucinta e clara as principais características das nossas fontes de inspiração base que foram o "aikido" e a "capoeira" para que o leitor pudesse entender qual recorte decidimos fazer das artes em questão, tendo em vista que se trata de um universo cultural extremamente amplo. E, por fim, nos capítulos seguintes, expusemos de que forma se deu o encaminhamento da prática que objetivou a transposição dos 
elementos marciais para a cena, procurando deixar claro o passo a passo do treinamento. Acreditamos, assim, que com esta organização o leitor possa compreender de que maneira se desenvolveu a pesquisa, mesmo sem ter acompanhado os treinamentos como ator ou observador.

Em outras palavras, podemos dizer que durante a elaboração desta tese desejamos que as informações práticas e teóricas aqui apresentadas servissem também como material de trabalho para outros atores, diretores e pesquisadores das artes cênicas que não participaram da prática, mas que teriam interesse em continuar desenvolvendo o que foi aqui iniciado. Portanto, é importante para nós a compreensão de que não entendemos esta pesquisa como um trabalho concluído, mas como uma investigação que pode haver muitos outros desdobramentos e prolongamentos a partir do olhar de cada um sobre ela.

Objetivamos, desta forma, que tudo o que foi aqui abordado sirva como semente e inspiração para outras experimentações e criações, afastando qualquer ideia de término e de fim. Mesmo o resultado cênico concebido a partir da peça Hamlet de W. Shakespeare que foi nesta tese descrito ao longo do capítulo 5, é visto por nós como um trabalho em processo que poderá ser continuamente aprofundado a partir do interesse e da disponibilidade dos atores. Acerca disso, é importante ressaltar que o encaminhamento de cada ensaio respeitou as limitações e potencialidades de cada ator, visando tanto o aproveitamento das qualidades apresentadas por cada um durante a prática quanto a superação de limites e o desenvolvimento de habilidades. Por consequência, o resultado prático final não apresenta uma homogeneidade em termos de qualidade técnica e artística, podendo-se observar níveis diferentes de atuação e de desenvoltura corporal. Em outras palavras, podemos dizer que, tendo em vista que o trabalho focou a formação do artista teatral, respeitando as características de cada participante, não tivemos a preocupação de chegar a um resultado virtuoso, mas de alcançar efetivamente uma evolução individual por meio dos recursos oferecidos pelas duas artes marciais pesquisadas.

Assim, mais do que uma titulação, procuramos com esta pesquisa um aprofundamento do trabalho do ator por meio de procedimentos ancorados no "aikido" e na "capoeira", dando suporte para o trabalho cênico, na medida em que explora as potencialidades do corpo como um todo, e propõe a ampliação de repertório que faça com que a criatividade seja estimulada. 


\section{Referências bibliográficas}

BARBA, Eugenio e SAVARESE, Nicola. A Arte Secreta do Ator: Dicionário de Antropologia teatral. Campinas: Editora da Unicamp, 1995.

BARBA, Eugênio. Além das Ilhas Flutuantes. Trad. Luis Otávio Burnier. Campinas: Unicamp. 1991.

BARBA, Eugenio. A Canoa de Papel. Tratado de Antropologia Teatral. Trad. Patrícia Alves. Campinas: Hucitec, 1994.

BOLESLAVSKI, Richard. A Arte do Ator. São Paulo: Perspectiva, 1992.

BONFITTO. Matteo. Entre o Ator e o Performer. São Paulo: Perspectiva. 2013.

BROOK, Peter. A Porta Aberta. Trad. Antonio Mercado. 3 ed., Rio de Janeiro: Civilização Brasileira, 2002.

BUBER, Martin. I and Thou. Trad. Walter Kaufmann. New Tork: Touchstone, 1971.

Between Man and Man. Trad. Ronald Gregor-Simith. London and New York: Routledge Classics, 2002. Moraes.1974.

Eu e Tu. Trad. do Alemão por Newton Von Zuben. 8 ed. São Paulo:

BURNIER, Luís Otávio. A Arte do Ator - da técnica à representação. Campinas: Unicamp, 2001.

BULL, Wagner. Aikido. O Caminho da Sabedoria: A Técnica. 10 ed. São Paulo: Educ, 2000.

CARVALHO, Marco. Feijoada no Paraíso - a Saga de Besouro, o Capoeira - São Paulo: Record, 2001.

CAMPBELL, Joseph. O Poder do Mito. São Paulo: Palas Athena, 1990.

CANCLINI, Néstor García. Culturas Híbridas: estrategias para entrar y salir de la modernidad. Cidade do México: Editorial Grijalbo, 2004.

CHEKOV, Michael. Para o Ator. São Paulo: Martins Fontes, 1996.

COELHO, Francisco Adolfo. Dicionário Manual Etimológico da Língua Portuguesa/contendo a significação e prosódia. Lisboa: P. Plantier. 1890.

CRUZ, José Luiz Oliveira. Capoeira Angola - do Iniciante ao Mestre - Bahia: Pallas, 2006.

CSIKSZENTMIHALYI, Mihaly. Beyond boredom and anxiety .San Francisco: Jossey-Bass, 1975.

CURI. Alice Stafânia. Traços e Devires de um Corpo Cênico. Brasília: Dulcina, 2013.

DAMASIO. Antonio. Looking for Spinoza. Joy, Sorrow, and the Feeling Brain. Nova York: Harvest Book. 2003.

O Mistério da Consciência. 10 ed. São Paulo: Companhia das Letras, 2013.

DECANIO FILHO, A. A Herança de Mestre Bimba. Salvador: ed. do autor, 1997.

A Herança de Mestre Pastinha. Salvador: ed. do autor, 1997. 
A. Falando em Capoeira. Salvador: ed. do autor, 1997.

DE MARINIS, Marco. Corpo e Corporeidade no teatro: da semiótica às neurociências. Um glossário Interdisciplinar. In: Revista Brasileira de Estudos da Presença. Porto Alegre,. v. 2, n.1, p. 42 - 61, 2012.

FABIÃO, Eleonora. Performance e Teatro: poéticas e políticas da cena contemporânea. In: Revista Sala Preta, Ppgac/USP, v. 8, n 1, 2008.

Corpo Cênico. Estado Cênico. In: Revista Contrapontos - Eletrônica, Vol. 10 - n. 3 - p. 321-326 / set-dez, 2010.

FERRACINI, Renato. A Arte de não Interpretar como Poesia Corpórea do Ator. Campinas: Editora da Unicamp, Imprensa Oficial do Estado S. A. - IMESP, 2001.

FILlAT, Josep M. Romero. M de Música, del Oído a La Alquimia Emocional. Tapa Blanda: Alba Editorial. 2011.

FÉRAL. Josette. Por uma poética da performatividade: o teatro performativo. Revista Sala Preta. 15 de abril de 2009. p. 197 a 210

FISCHER-LICHTE. Erika. The Transformative Power of Performance. A new Aesthetics.Translated by Saskya Iris Jain. London/New York: Routledge, 2008.

GIROUX. Sakae. M. Zeami: Cena e Pensamento Nô. São Paulo: Perspectiva. 1991.

GOMES-PEÑA, Guillermo. En Defensa del arte del performance. Horizontes Antropológicos, Porto Alegre: ano 11, n. 24, p. 199-226, jul/dez. 2005

GONÇALVES, António Custódio. A memória cultural na simbolização dos rituais sociais. Porto: Universidade do Porto. Faculdade de Letras, 1999.

GREINER, Christine. O Corpo: Pista para Estudos Interdisciplinares. São Paulo: Annablume, 2005.

GROTOWSKI, Jerzy. Em Busca de um Teatro Pobre. Rio de Janeiro: Civilização Brasileira, 1992.

HOLLOWAY. Thomas. O saudável terror: repressão policial aos capoeiras e resistência dos escravos no Rio de Janeiro no século XIX. Revista de Estudos AfroAsiático, n. 16, 1989.

HUIZINGA, Johan. Homo Ludens. O Jogo como Elemento da Cultura. São Paulo: Perspectiva, 1995.

KATZ, Helena. 1,2,3. A Dança é o Pensamento do Corpo. Belo Horizonte: FID, 2005. KOUDELA, Ingrid Dormien. Jogos Teatrais. São Paulo: Perspectiva, 1992.

Texto e jogo. São Paulo: Perspectiva/Fapesp, 1996.

KUHL, Ole. The Semiotic Gesture. In Centre of Semiotics, University of Aarhus; Royal Academy of Music, Aarhus, 2011

LABAN, Rudolf. Domínio do Movimento. Trad. Anna Maria Barros de Vecchi e Maria Silvia Mourão Netto, $4^{a}$ ed., São Paulo: Summus, 1978 .

MEELBERG. Vicent. In New Perspectives on Music and Gesture, edited by Anthony Gritten and Elaine King, p. 127-129. Farnham: Ashgate, 2011.

MERLEAU-PONTY, Maurice. Fenomenologia da Percepção. Trad. Carlos Alberto Ribeiro de Moura. $2^{a}$ ed., São Paulo: Martins Fontes, 1999. 
Fenomenologia da Percepção. Trad. Carlos Alberto Ribeiro de Moura. São Paulo: Martins Fontes, 2006.

MORIN, Edgar. Introdução ao Pensamento Complexo. Tradução Dulce Matos. 4. ed. Lisboa: Instituto Piaget, 2003.

NOE, Alva. Action in Percetion. Mit Pr, 2009.

NOE, Alva. Out of Our Heads. Why You Are Not Your Brain, and Other Lessons from the Biology of Consciousness. NY: Farrar, Straus and Giroux Inc. 2010.

NIETZSCHE, Friedrich. O Nascimento da Tragédia. Companhia das Letras, São Paulo,1996.

OIDA, Yoshi. O ator invisível. Trad. Marcelo Gomes. São Paulo: Via Lettera, 2014.

O Ator Errante. Trad. Marcelo Gomes. São Paulo, Via Lettera, 2012.

ORTEGA Y GASSET, José. A Ideia do Teatro. Trad. J. Guinsburg. São Paulo: Perspectiva, 1991.

PASTINHA, Vicente Ferreira. Capoeira angola: por mestre Pastinha, 2 ed. Salvador: Escola gráfica Nossa Sra. do Loreto, 1968.

PAVIS, Patrice. Uma Canoa a deriva? 2007(não publicado). Tradução disponibilizada por Mônica Mello e Joyce Aglae.

PRADIER, Jean-Marie. Le Public et son Corps: eloge des sens. Théâtre/Public, Gennevilliers, n. 120, 1994.

RANCIÈRE. Jacques. EI Espectador Emancipado. Buenos Aires: Manantial. 2010.

REGO, Waldeloir. Capoeira Angola: Ensaio Sócio Etnográfico. Salvador: Itapuã. 1968.

RENGEL, Lenira. Dicionário Laban. 2a ed. São Paulo: Annablume, 2005.

Os temas de Movimento de Rudolf Laban. São Paulo: Annablume, 2008.

ROHAN, Hemrique de Beaudepaire. Reforma da Ortografia Portuquesa, in Revista Brasileira, N. Midosi, Rio de Janeiro: 1979, Tomo II.

ROMANO. Lúcia. O Teatro do Corpo Manifesto: Teatro Físico. São Paulo: Perspectiva, 2013.

SANTOS, Maria Thais Lima. Na Cena Com Dr. Dapertutto. São Paulo: Perspectiva. 2009.

SCHECHNER, Richard. Estudios de la Representacion. México: Fundo de Cultura Econômica, 2012.

SET, Mestre Bola. Capoeira Angola na Bahia. 3 ed. Bahia: Pallas. 2006.

SILVA, Eusébio Lôbo da. O Corpo na Capoeira: Vol. 1 - Introdução ao Estudo do Corpo na Capoeira, Campinas: UNICAMP, 2008.

SILVA, Eusébio Lôbo da. O Corpo na Capoeira. Breve Panorama: Estórias e Histórias da Capoeira. Vol. 2, Campinas: UNICAMP, 2008.

SILVA, Eusébio Lôbo da. O Corpo na Capoeira: Fundamentação Operacional dos Movimentos Básicos da Capoeira. Vol. 3, Campinas: UNICAMP, 2008. 
SILVA, Eusébio Lôbo da. O Corpo em Ação na Capoeira: Vol. 4, Campinas: UNICAMP, 2008.

SILVA, Armando Sérgio da. Oficina da Essência. São Paulo: CACA/ECA/USP, 2003.

SNYDER, Bob. Music and Memory: an introduction. Cambrigde/London: The MIT Press. 2000.

SPINOZA, Barush. Ética. Trad. Tomaz Tadeu. Belo Horizonte: Autêntica, 2009.

SPOLIN,Viola. O Jogo Teatral no Livro do Diretor. São Paulo: Perspectiva, 2001. Improvisação para Teatro. 4 ed. São Paulo: Perspectiva, 2003. Jogos Teatrais - O fichário de Viola Spolin. São Paulo: Perspectiva, 2000.

STANISLAVSKI, Constantin. A Construção da Personagem. Rio de Janeiro: Civilização Brasileira, 1990.

A Criação de um Papel. Rio de Janeiro: Civilização Brasileira, 1990.

A Preparação do Ator. Rio de Janeiro: Civilização Brasileira, 1986.

STEVENS. John. A Filosofia do aikido. Trad. Paulo Proença. São Paulo: Cultrix. 2001

STOBBAERTS, Georges. Aikido: a procura da unidade. Lisboa: Ten chi International, 2001.

STOBBAERTS, Georges. O Corpo e a Expressão Teatral. Lisboa: Hugin, 2001.

TOHEI, Koichi. O Livro do Chi. Como Coordenar Corpo e Mente na Vida Diária. Trad. Afonso Teixeira Filho. São Paulo: Manole, 2000.

TURNER, Victor. O Processo Ritual. Estrutura e Antiestrutura. Trad. Nancy Campi de Castro. Petrópolis: Vozes, 1974.

UESHIBA, Kisshomaru. O Espírito do Aikido. Trad. Euclides Luiz Calloni, $11^{\text {a }}$ ed., São Paulo: Cultrix, 2007.

UESHIBA, Moriteru. The Aikido Master Course. Best Aikido 2. Trad. para inglês John Stevens. Tokyo: Kodansha International, 2003.

WESTBROOK, Adele e RATTI, Oscar. Aikido e a Esfera Dinâmica. Trad. Carina de Souza Lucindo. São Paulo: Madra, 2006.

ZEAMI, Motokiyo. Il Segreto del Teatro Nô. Milano: Adelphi Edizioni S.P.A, 1966.

ZBIKOWSKI, Lawrence M. Musical Gesture and Musical Grammar: A Cognitive Approach. In New Perspectives on Music and Gesture, edited by Anthony Gritten and Elaine King, p. 83-98. Farnham, Surrey: Ashgate, 2011.

\section{WEBSITES}

FILHO, Ciro Marcondes. Ensaio divulgado no website da ECA-USP (Maio-agosto 2007). Método: Uma Nova Teoria da Comunicação. Disponível em http://www.eca.usp.br/nucleos/filocom/existocom/ensaio13a.html. Acessado em 01 de fevereiro de 2013.

FILHO, Ciro Marcondes. Método: Uma Nova Teoria da Comunicação (Agosto 2010). Disponível em https://sites.google.com/site/ecafilocom/home/textos. Acessado em 19 de julho de 2016. 
KOUDELA, Ingrid Dormien. Jogos Teatrais na Formação de Pedagogos. Fênix Revista de História e Estudos Culturais. Janeiro a Abril de 2010 Vol. 7 Ano VII n ${ }^{\circ} 1$. ISSN: 1807-697. Disponível em: www.revistafenix.pro.br. Acessado em 02 de abril de 2016.

NISHIDA, Makoto. Técnica Sólida e Técnica Flexível. São Paulo: FEPAI. 2008. Disponível em http://www.fepai.org.br/news/new_info0008.htm. Acessado em 01 de março de 2015.

NOGUEIRA, Marcos. 2003. "O imaginário metafórico da escuta." Semiosfera - Revista de Comunicação e Cultura, no. 4-5. Disponível em http://www.eco.ufrj.br/ semiosfera/anteriores/semiosfera45/conteudo_imag_mnogueira. htm. Acessado em 01 abril de 2015.

SCHECHNER, Richard. What is performance? In Performance Studies: An Introduction. 2 ed. New York \& London: Routledge. 2007. Pg. 28-51. Disponível em https://performancesculturais.emac.ufg.br/up/378/o/O_QUE_EH_PERF_SCHECHNER .pdf. Acessado em 02 de outubro de 2015.

SHAKESPEARE, William. Hamlet. (baixado do site file:///C|/site/LivrosGrátis/Hamlet.htm em fevereiro de 2014)

SHAKPESPEARE, William Hamlet. Trad. Millor Fernandes. (baixado do site: http://www.encontrosdedramaturgia.com.br/wp-content/uploads/2010/10/ShakespeareHAMLET-Tradu\%C3\%A7\%C3\%A3o-Mill\%C3\%B4r-Fernandes.pdf em dezembro de 2016) 


\section{Anexo:}

\section{Experimentações com estudantes de teatro}

No primeiro semestre de 2015 tive a oportunidade de experimentar com alunos de teatro os procedimentos descritos neste trabalho. Eram pessoas que ainda estavam no curso profissionalizante, desejosos de se aprimorar. Foram reservados oito encontros para o "aikido" e oito para a "capoeira". Segui com eles a mesma sequência de treinamento e processo de criação descrita ao longo desta tese, mas de forma mais sucinta. Ao final de processo com cada arte marcial, cenas eram criadas e apresentadas.

A fim de acompanhar a evolução deles e registrar o processo pedi que eles anotassem impressões do que vivenciaram e me enviassem de modo que eu pudesse ir organizando os procedimentos dos encontros seguintes. Foram vários depoimentos colhidos ao longo de todo o semestre. Seguem abaixo alguns trechos.

Pude perceber nos depoimentos dos alunos-atores que houve inicialmente certa dificuldade e estranhamento em relação ao uso de uma arte marcial para o trabalho do ator. Em certa medida atribuí isto a pouca experiência dos envolvidos. Alguns pontos levantados por eles como "difíceis" foram: relação com o outro, pensamento com o corpo todo durante a improvisação, fluidez dos movimentos, quebra de padrões, descobertas de novas possibilidades expressivas e dificuldade de se apropriar do repertório novo. Mas foi interessante observar que eles se mantiveram motivados durante todo o processo e animados para superar as próprias limitações. Algumas conquistas desse período foram: noção do corpo todo trabalhando como uma unidade, descoberta dos próprios pontos frágeis e fortes, ampliação da conscientização sobre o corpo, quebra de padrões, interesse por um assunto dos quais não tinham conhecimento, aprimoramento das habilidades corporais e artísticas e potencialização da "escuta" e da relação com o outro.

Para a etapa de criação os dividi em grupos menores e pedi que relacionassem sensações e imagens surgidas durante as improvisações livres. Segue algumas impressões registradas: externalizar o que está sentindo, mudanças rápidas, urgência, psicose, mudança de humor, nascimento, família, caçador e presa, despedida, troca de energia, comunhão, sexo tântrico e vôo das andorinhas. A partir desse levantamento começamos a definir um tema para cada grupo e seguiram-se os improvisos. Na 
sequência, deveriam criar uma cena a partir de todo o material levantado nas improvisações.

A cada semana eles podiam trazer novos estímulos externos que dialogassem com o que estava surgindo na prática como música, conto, imagem, objeto, dentre outros. Seguindo estes procedimentos os atores foram definindo uma partitura de cena que foi ao final repetida algumas vezes a fim de se trabalhar a limpeza e a lapidação dos movimentos.

Imagens de algumas improvisações a partir dos elementos do aikido.
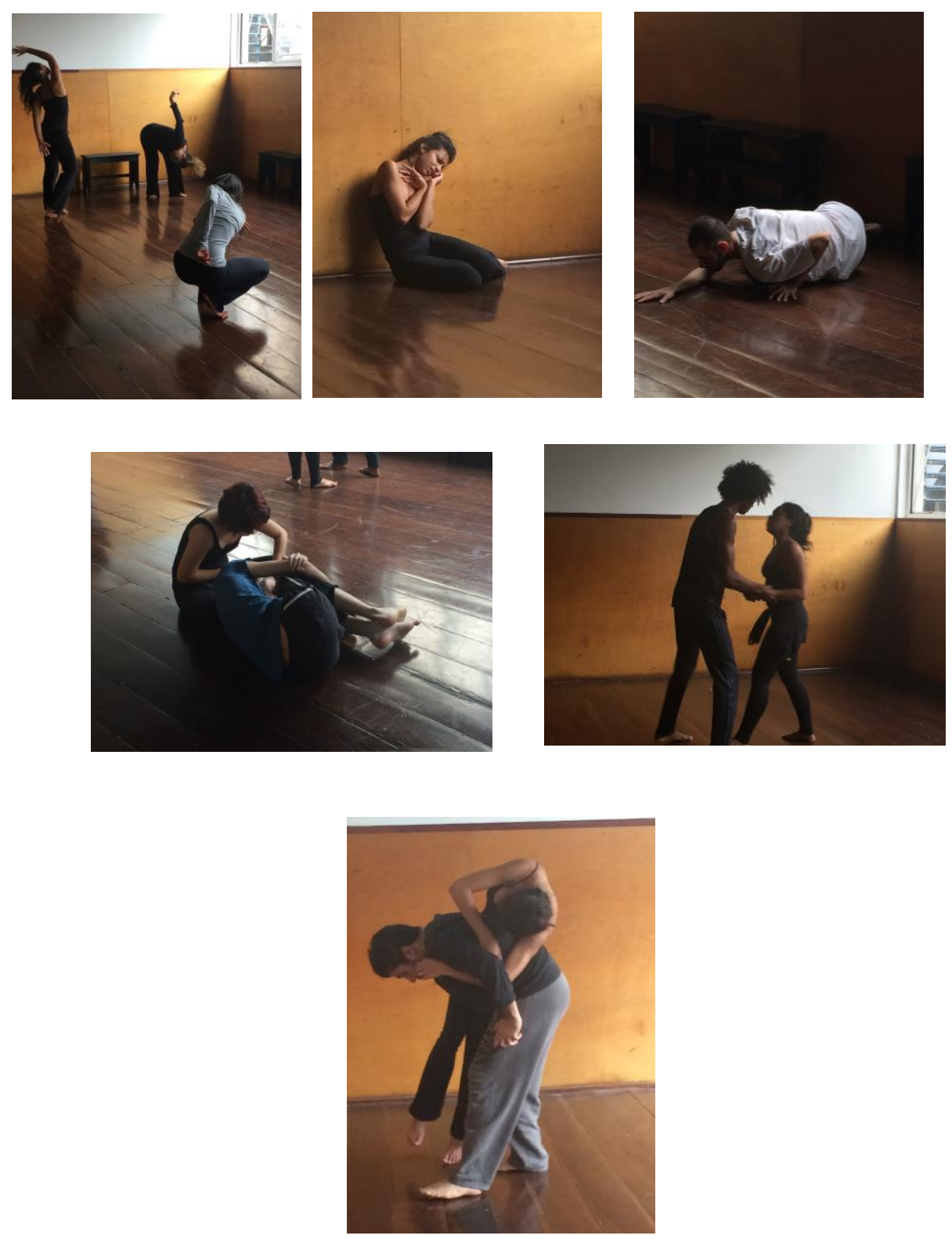

Imagens de algumas improvisações a partir da capoeira: 

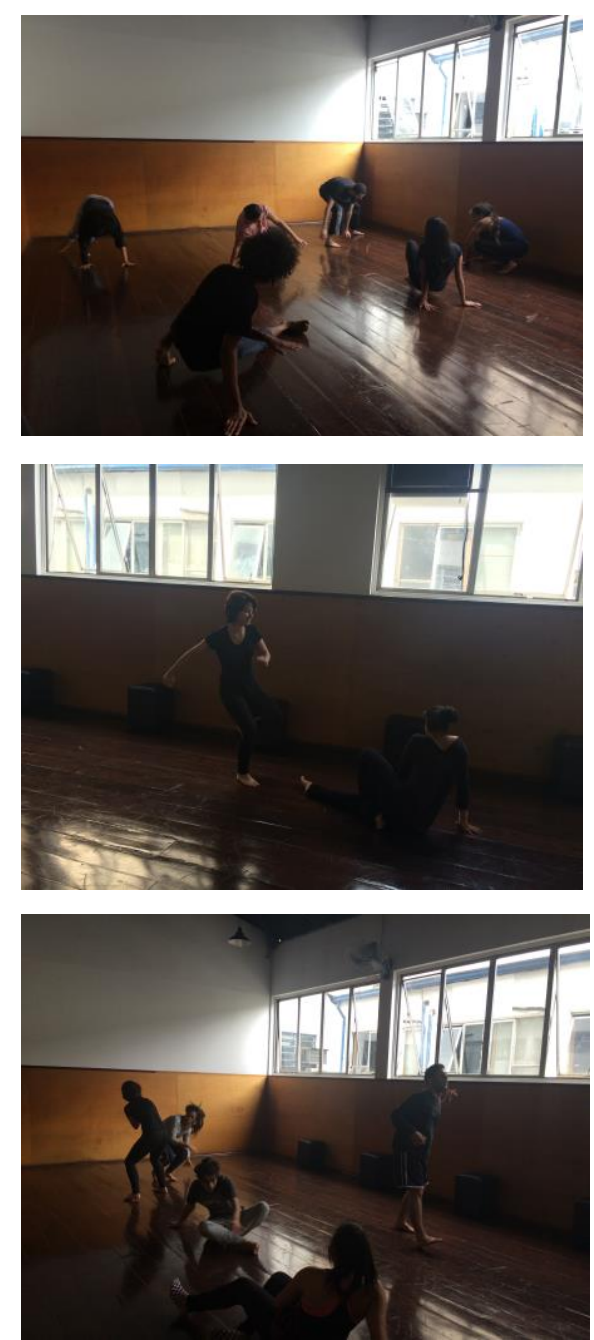
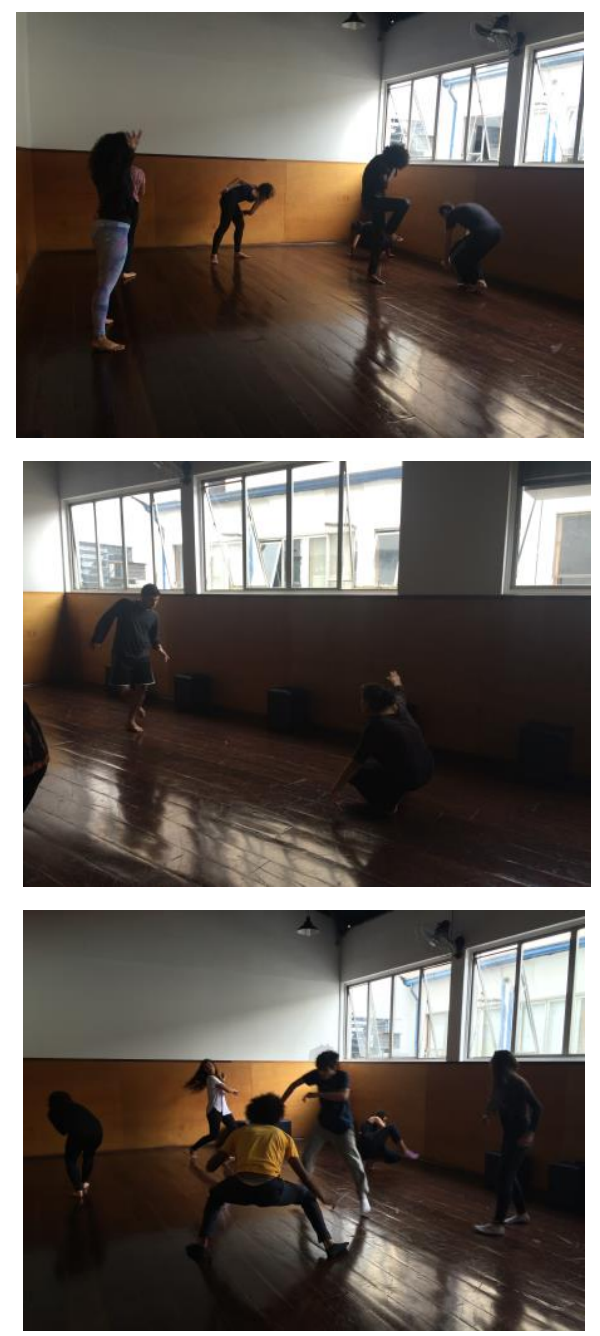

\section{Depoimentos:}

Aluno Renato Crovella:

$\mathrm{O}$ aquecimento no início nitidamente me ajudou a realizar as propostas que vinham na sequência! Senti meu corpo alongar e a "acordar". No caso do aikido, com a improvisação em dupla, aproveitando o impulso do parceiro, não foi tão simples a princípio. Com algumas duplas foi divertido, fluído e desafiador, mas com outras encontrei mais dificuldade. Era nítida a diferença de energia em cada dupla. Com alguns parceiros, o jogo fluía enquanto, com outros, "travava".

(...) Tenho "mania" de racionalizar as coisas e, acredito eu, que isso afetava minha resposta corporal. Com o tempo fui me sentindo mais solto e livre.

(...) Percebi ao longo das improvisações que cada dupla estabelece uma relação que provoca ações e reações próprias. Cada pessoa tem uma forma particular de reagir ao estímulo dado! E isso é muito legal, já que todos nós estamos em constante mudança até o dia em que morremos e, logo, por mais que eu atue com a mesma pessoa por um longo período de tempo, essa pessoa não será a mesma todo esse 
tempo e toda vez que tivermos que atuar, uma nova relação será criada e um novo jogo se estabelece!

(...) Outra coisa que me chamou muita atenção foram as imagens e sensações que "nasceram" do improviso. Foram muito fortes! Me deu muito estímulo para criar a cena.

Aluno Michel Oliveira:

As aulas tem me ajudado a retirar a trava e resistência que tenho em relação a expressão corporal.

Aluna Letícia Lima

Achei muito interessante usarmos técnicas do aikido e da capoeira como pesquisa. Durante as aulas percebi que com a prática se adquire resistência e equilíbrio e melhora o preparo físico. Nas improvisações em dupla percebi que era só eu me deixar levar e jogar com meu parceiro. Parecia que o movimento já existia em mim, no meu corpo, então fluía.

Aluna Caroline Pianheri:

No início foi difícil, mas com o passar do tempo foi ficando mais fácil improvisar uma cena usando os elementos das artes marciais como inspiração e fui ficando menos racional. Fui percebendo que fui ficando mais criativa e mais segura.

\section{Aluna Gabriela Chiapeta:}

Desde os primeiros dias de aula me senti descobrindo meu corpo. Como é maravilhoso aprendermos a soltar nosso corpo para assim relaxarmos nossa mente e ficarmos mais leves!

Aluno Tainã Oliveira:

Eu tenho problemas com flexibilidade corporal, porém ao longo das aulas com os alongamentos e exercícios, tenho evoluído. As aulas têm exercitado a minha concentração e percepção corporal, estou dominando mais meu corpo em relação ao equilíbrio.

\section{Aluna Tainá Oliveira:}

Achei interessante a forma como uma arte marcial pode ser usada em sua essência para o trabalho corporal (do ator), como movimentos circulares podem dar origem a outros movimentos e se transformarem em algo novo e bonito. O que muito me agradou foi o fato dessas artes trabalharam muito a relação com o outro, ou seja, criar a partir da ação do outro. Esse jogo acho essencial, importante. 
Aluna Andressa Maria:

Os exercícios praticados dentro de cada técnica requerem muita atenção, foco, concentração e equilíbrio do corpo. O que acho mais interessante em todo esse processo são as criações em geral, cada técnica dá a oportunidade de criar vários movimentos que eu não imaginava fazer.

Aluna Thais Fernandes:

Com a descoberta que trabalharíamos com base no aikido e na capoeira houve um estranhamento da minha parte. Nunca me imaginei fazendo qualquer tipo de arte marcial e também não conseguia compreender qual a relação que isso teria com o trabalho do ator. Logo na primeira aula essas dúvidas foram desaparecendo e entendi que seria um grande desafio para mim e que me daria uma nova relação com meu corpo. Pesquisando sobre o aikido descobri que significa "o caminho da unificação da energia da vida" e desde então me coloquei nesse desafio de alcançar esta unificação. 